\title{
A METHODOLOGY FOR CONTROLLING AIR POLLUTION EPISODES
}

\author{
by \\ T. D. Wolsko, M. T. Matthies, \\ and R. F. King
}

\section{ANL \\ CES}

ARGONNE NATIONAL LABORATORY

CENTER FOR ENVIRONMENTAL STUDIES

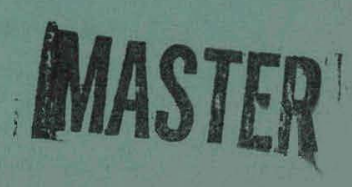




\section{DISCLAIMER}

This report was prepared as an account of work sponsored by an agency of the United States Government. Neither the United States Government nor any agency Thereof, nor any of their employees, makes any warranty, express or implied, or assumes any legal liability or responsibility for the accuracy, completeness, or usefulness of any information, apparatus, product, or process disclosed, or represents that its use would not infringe privately owned rights. Reference herein to any specific commercial product, process, or service by trade name, trademark, manufacturer, or otherwise does not necessarily constitute or imply its endorsement, recommendation, or favoring by the United States Government or any agency thereof. The views and opinions of authors expressed herein do not necessarily state or reflect those of the United States Government or any agency thereof. 


\section{DISCLAIMER}

Portions of this document may be illegible in electronic image products. Images are produced from the best available original document. 
The facilities of Argonne National Laboratory are owned by the United States Government. Under the terms of a contract (W-31-109-Eng-38) between the U. S. Atomic Energy Commission, Argonne Universities Association and The University of Chicago, the University employs the staff and operates the Laboratory in accordance with policies and programs formulated, approved and reviewed by the Association.

\section{MEMBERS OF ARGONNE UNIVERSITIES ASSOCIATION}

The University of Arizona Carnegie-Mellon University Case Western Reserve University The University of Chicago University of Cincinnati Illinois Institute of Technology University of Illinois Indiana University Iowa State University The University of Iowa
Kansas State University The University of Kansas Loyola University Marquette University Michigan State University The University of Michigan University of Minnesota University of Missouri Northwestern University University of Notre Dame
The Ohio State University Ohio University The Pennsylvania State University Purdue University Saint Louis University Southern Illinois University The University of Texas at Austin Washington University Wayne State University The University of Wisconsin

\section{NOTICE}

This report was prepared as an account of work sponsored by the United States Government. Neither the United States nor the United States Atomic Energy Commission, nor any of their employees, nor any of their contractors, subcontractors, or their employees, makes any warranty, express or implied, or assumes any legal liability or responsibility for the accuracy, completeness or usefulness of any information, apparatus, product or process disclosed, or represents that its use would not infringe privately-owned rights.

Printed in the United States of America Available from

National Technical Information Service

U.S. Department of Commerce

5285 Port Royal Road

Springfield, Virginia 22151

Price: Printed Copy $\$ 3.00$; Microfiche $\$ 0.95$ 
ANL/ES-14

Meteorology

ARGONNE NATIONAL LABORATORY

9700 South Cass Avenue

Argonne, Illinois 60439

\section{A METHODOLOGY FOR CONTROLLING}

AIR POLLUTION EPISODES*

by

\section{Thomas D. Wolsko, Michae1. T. Matthies, **} and Richard F. King

Center for Environmental Studies

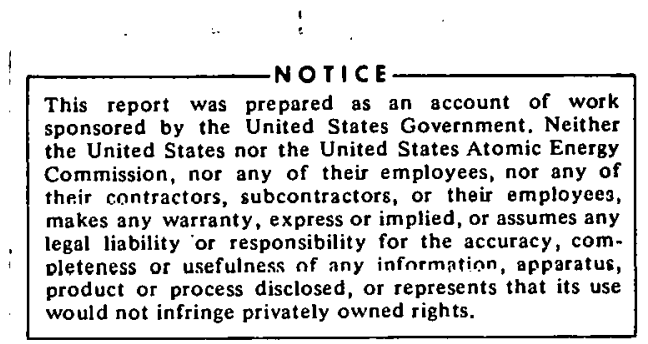

*Work sponsored by the U. S. Environmental Protcction Agency, Emergency Operations Contro1 Center, Interagency Agreement: No. EPA-IAG-0025(R) .

**Applied Mathematics Division. 
THIS PAGE

\section{WAS INTENTIONALLY LEFT BLANK}


TABLE OF CONTENTS

$\underline{\text { Page }}$

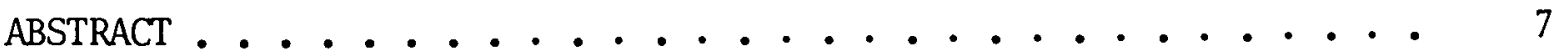

I. INTRODUCTION ....................... 8

II. SOURCE EMISSION FILE . . . . . . . . . . . . 10

A. Emission Data Lists . . . . . . . . . 15

B. General Source Listing ............. 16

C. Source Priority Listing ........... 20

D. Jurisdictional Ordering ............ 23

E. Single Source Tables Listing . . . . . . . . 27

F. Area Source Locations . . . . . . . . . 29

III. DISPERSION ANALYSIS ............... . . 30

A. Argonne Steady State Model (ASSM) . . . . . . 33

B. Plume Rise ................ . . . 34

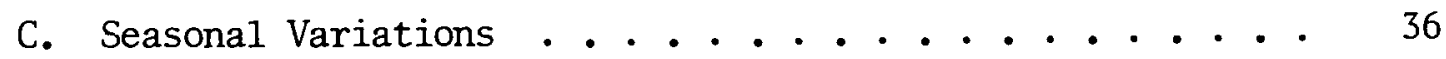

D. Space Heating ..................... 37

E. Mixing Height ................... 39

F. Vertical Diffusion............. 40

G. Horizontal Dispersion ............ 42

IV. ISOPLETH PLOTTING . . . . . . . . . . . . . 43

A. Isopleth Plotting System . . . . . . . . . 43

B. Film-Plotting Subsystem ........... 45

C. Film-Plotting Subroutine Package Routines ...... 46

V. EPISODE CONTROL METHODOLOGY . . . . . . . . . 50

A. Episode Control Data Base Development . . . . . . 52

1. Source Emission Inventory . . . . . . . 52

B. Episode Control Strategy Development . . . . . . . 71

1. Define Episode Potential . . . . . . . . 71

2. Examine Pollution Contours for the Particular Meteorological Conditions ......... . 71

3. Check Pollution Contours against Monitored Air ... 75

4. Identify Culpable Sources .......... 75

5. Determine Control Strategy . . . . . . . . 77 
TABLE OF CONTENTS

Page

VI. EPILOGUE . . . . . . . . . . . . . 78

APPENDIX A. Sample Lists and Computer Program Listings for the

Regional Source File...........

81

1. Ordered List of $\mathrm{SO}_{2}$ Emitters in Chicago Region according to Jurisdiction together with Its

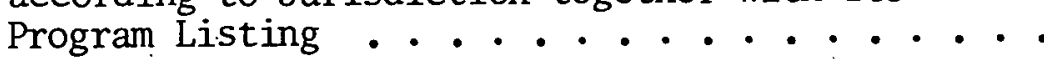

2. Ordered List of $\mathrm{SO}_{2}$ Emitters in Chicago Region Together with Its Program Listing ....... 91

APPFNTTX R, ASSM Prngram . . . . . . . . . . . . . 101

1. ASSM Program Listing and Subroutine Description . 101

2. Input Description . . . . . . . . . . . 128

3. Glossary of ASSM Input Variables ... . . . . 147

4. Output Description ........... . 150

5. Sample Problem ............... 165

APPENDIX C. Description and Use of ASSM Plotter Program . . . . 167

1. Plotter Program Listing and Documentation . . . 167

2. Input Description . . . . . . . . . . . 185

3. output Description and Sample Prohlem . . . . . 196

$\Lambda$ PENDIX D. Episodo Display . . . . . . . . . . . 20?

ACKNOWLEDGMENTS . . . . . . . . . . . . . . . . . 204

REFERFNCES ....................... 205 


\section{LIST OF FIGURES}

No.

Title

Page

1 IPP Input-data Form; Point Source . . . . . . . . . .

2 IPP Input-data Form; Area Source . . . . . . . . . . .

3 Largest Sulfur Dioxide Point Sources in the Chicago Metropolitan Air Quality Control Region. . . . . . . . . .

4 Largest Suspended-particulate Point Sources in the Chicago Metropolitan Air Quality Control Region . . . . . . . . .

5 Sulfur Dioxide Monitoring Sites in the Chicago Metropolitan Air Quality Control Region'. . . . . . . . 66

6 Pollution Contours for the Chicago Region Sample Episode .

7 Explanation of Source Culpability List . . . . . . . . 76

B-1 ASSM Program Structure . . . . . . . . . . . 101

B-2 ASSM Card Input Deck . . . . . . . . . . . . . 130

B-3 Data Input for Sample Problem . . . . . . . . . . 131

B-4 Chicago Region Receptor Grid . . . . . . . . . . . . . 134

B-5 Printed Output from the Sample Problem . . . . . . . . 153

B-6 Punched-card Output from the Sample Problem . . . . . . . 164

C-1 ASSM Plotting System . . . . . . . . . . . . 167

C-2 Plotting-system Input Deck .............. 185

C-3 Input for Sample Problem . . . . . . . . . . . 187

C-4 SYMAP Output for Sample Problem . . . . . . . . . . 197

C-5 Film Output for Sample Problem . . . . . . . . . 198

C-6 'Map Sumary Information" for Sample Problem . . . . . . . 199

D-1 . Typical Aperture Card with Regional Isopleths . . . . . . . 203

D-2 Episode Display Unit . . . . . . . . . . . . 203 


\section{LIST OF TABLES}

No.

$\underline{\text { Title }}$

$\underline{\text { Page }}$

I IPP-2 Inventory Format . . . . . . . . . 13

II General Source File for Chicago Metropolitan Air Quality Region ......................... 17

III SSFILE, Ordered List of $\mathrm{SO}_{2}$ Emitters in Chicago Region • • 21

IV PSFILE, Ordered List of Particulate Emitters in Chicago Region .................

$\mathrm{V}$ SJFILE, Ordered List of $\mathrm{SO}_{2}$ tmitters in Lhicago Region, according to Jurisdiction ?............ 24

VI PJFILE, Ordered List of Particulate Emitters in Chicago Region, according to Jurisdiction ......... 25

VII Political Jurisdiction Key for Chicago Metropolitan Air Quality Control Region ............ 26

VIII TFILE, Source Log for Isopleth-area Tables; Chicago Region ................. 28

IX Sulfur Dioxide Emissions in the Chicago Region . . . . . . 57

$\mathrm{X} \quad$ Particulate Emisșions in the Chicago Region . . . . . . . 59

XI Controllable Industrial Plants with Large Sulfur Dioxide Enlissiuns . . . . . . . . . . . . . 61

X11 Commonwealth Edison (Power) Plantss in lhe Chicayu Region . 62

XIII Sulfur Dioxide Monitoring Stations in the Chicago Region . 64

XIV Typical List of Monitoring Stations and Their Instruments (Chicago Metropulitan Air Quality Control Region). . . , , 65

XV Sampling-method Key for Monitoring Stations........ 67

XVI Average Chicago Seasonal Mixing Heights and Tëmperatures . 67

XVII Culpability List ............... . . 73

B-1 Default Meteorological Data . . . . . . . 138

B-2 Description of LABEL Identifier . . . . . . . 144

C-1 Film and Printer Labels ............. 201 
A METHODOLOGY FOR CONTROLLING

AIR POLLUTION EPISODES

by

T. D. Wolsko, M. T. Matthies, and R. F. King

\section{ABSTRACT}

A methodology for developing effective, preplanned emission control strategies for urban air pollution episodes is presented. A steady-state Gaussian dispersion model is applied to known emission inventories for various sets of meteorological conditions that are liable to exist during episodes. Calculated pollution contours are plotted directly on $35 \mathrm{~mm}$ film for projection into a larger display format that is convenient for identifying episode problems and planning control strategies. A hypothetical episode is used to illustrate techniques. Although the procedures were designed to control sulfur dioxide and particulate matter, they are applicable for any non-reacting, airborne pollutant. 


\section{INTRODUCTION}

Air pollution episodes come about when meteorological conditions reduce the volume of air in which the pollutants can be dispersed. If the conditions persist and sources continue to emit pollutants, the ambient air quality will deteriorate. Source emission reduction is the only means by which severe short-term air pollution problems can be resolved. However, emission reduction strategies are likely to involve more operational and economic disruption than the episode itself. Because control strategies affect the metabolism of an urban economy, they must be carefully selected to minimize disruption and yet effectively resolve the air pollution problem. Without an effective method for developing control strategies, the episode control planner will most likely over-control sources in the area.

This report describes a methodology for developing effective control strategies that minimize the constraints on the economy. 'The methodology is designed for large urban areas with short-term air pollution episodes and not for the abatement of long-term air pollution problems. Although the procedures were designed to control sulfur dioxide and particulate episodes, they are applicable for any non-reacting pollutant.

Episode control strategy development is considered as a preplanned task in this methodology. That is, the data necessary to determine the most effective control strategy is calculated and available before the episode actually develops. Preplanning for episodes leaves more time for implementing the control strategies.

The main thrust of the methodology is to precalculate pollution contours for episode-prone meteorological conditions so that a picture of the problem is available. Source emission data, pollutant dispersion, graphical 
display, and strategy development are all a part of the methodology to control episodes. Any emission source inventory can be used, but the system is designed to use data in the Implementation Planning Program format (IPP). Recent source inventories in the IPP format are available for most major metropolitan areas in the United States. Computer programs that process the inventory data into a source file and preprocess it for the dispersion program are available.

The dispersion program (ASSM) that calculates pollution contours (isopleths) is based on a steady-state Gaussian diffusion model. That is, it is assumed that meteorological conditions do not change radically during the episode, and this is usually the case. A complete description of the dispersion model is included in this report.

Outputs from the dispersion model must be assembled in a format that is usable by the control strategist. Plotting programs that provide pollution contours on 35m film directly from the computer have been developed. All programs are written for an IBM 50/75 computer, and film plotting is performed on the IBM 2280 film unit. The $35 \mathrm{~mm}$ film format was chosen because, with the aid of projection equipment, the larger format is convenient in identifying episode problems and planning control strategies. Descriptions of the plotting programs and their links to the dispersion model are available.

In addition to describing all the techniques, computer programs, and data gathering, the report contains a section devoted to the use of these tools for planning an episode control strategy. A hypothetical episode is used to illustrate the development of a control strategy for a major metropolitan area using the methodology described in this report. 


\section{SOURCE EMISSION FILE}

An essential part of any effective procedure for controlling air pollution episodes is a well-designed source emission file. The accuracy of the data is of course very important; but furthermore, because the response time for effective control procedures is short, the emission data must be assembled so that desired information can be located quickly. Convenient data files should be available for determining, applying, and analyzing episode control strategies.

Any emission inventory can be assembled to serve as the basis for a source emission file, but the procedures and programs described here are based upon the Implementation Planning Program (IPP) emission inventory format. This inventory format was chosen because the Federal Environmental Protection Agency has specified such a format for air quality planning programs. 'Iwo large computer programs were written to assist tederal, state, and local agencies in their air quality planning activities. The first of these programs is a dispersion program (Air Quality Display Model: AQDM) ; ${ }^{1}$ the second is designed to test air quality control strategies for costeffectiveness (Air Quality Implementation Planning Program: IPP).$^{2}$ Both of these programs use the IPP emission inventory format as input. A sample format is shown in Figs. 1 and 2. Even though these two complex programs have received very little use because of their complexity, emission inventories for most major urban air-sheds have been collected by the Environmental Protection Agency using this format. The IPP emission inventory format has recently been modified to the IPP- 2 format shown in Table I. Most changes in the format relate to data location and input format, while very few changes have been made with respect to the type of data. 


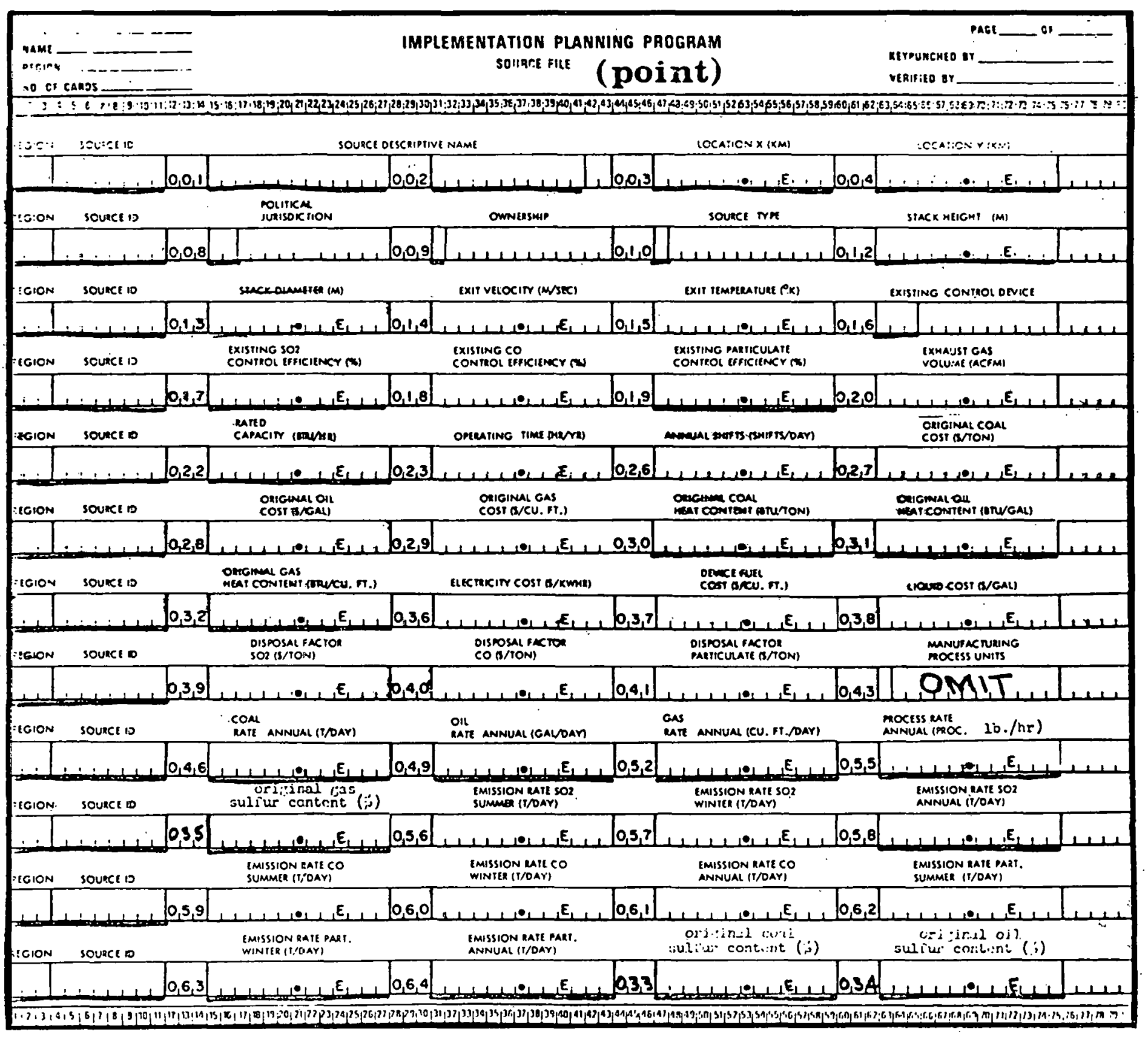

Fig. 1. IPP Input-data Form; Point Source 


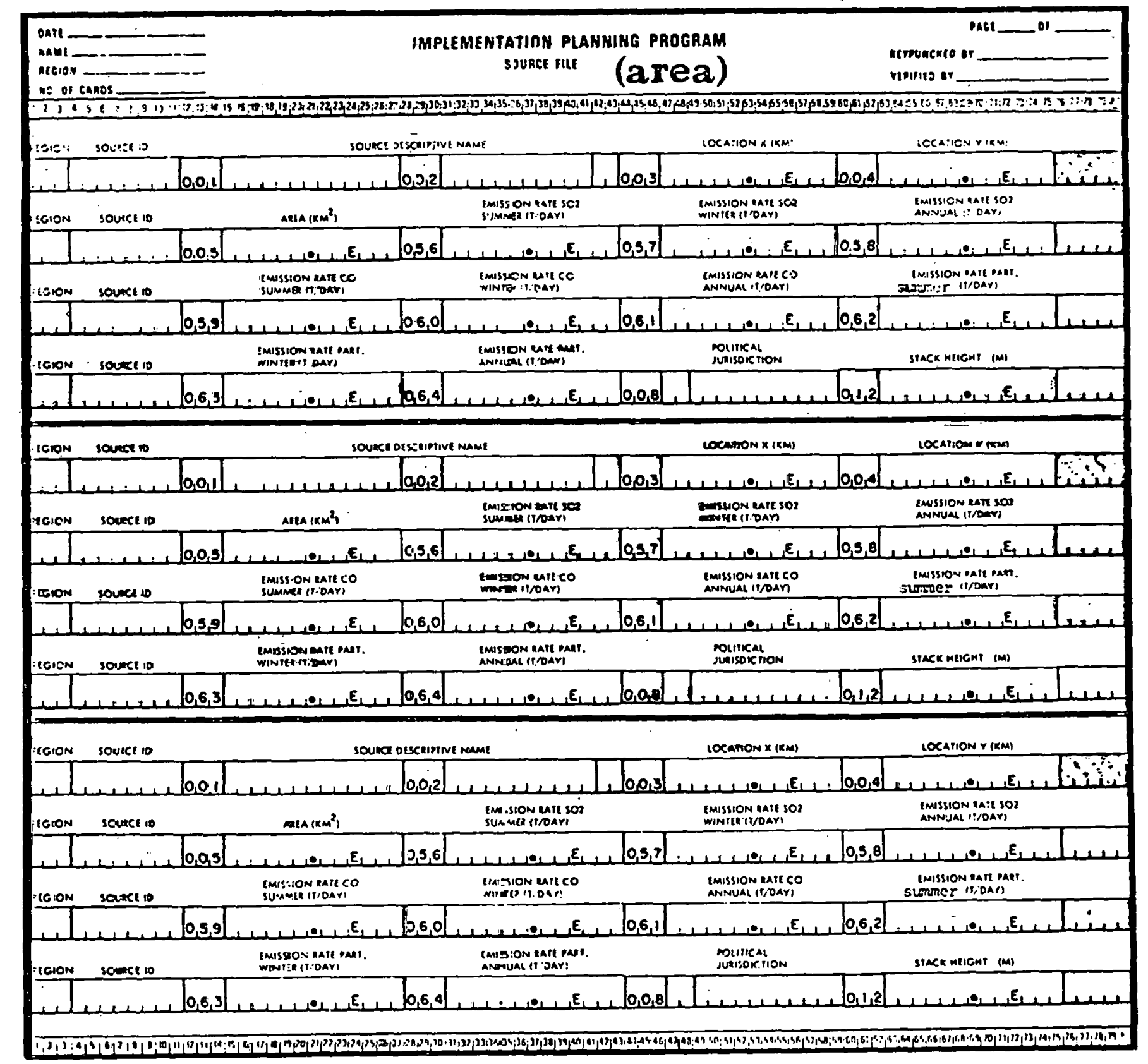

Fig. 2. IPP Input-data Form; Area Source 
TABLE I. IPP-2 Inventory Format

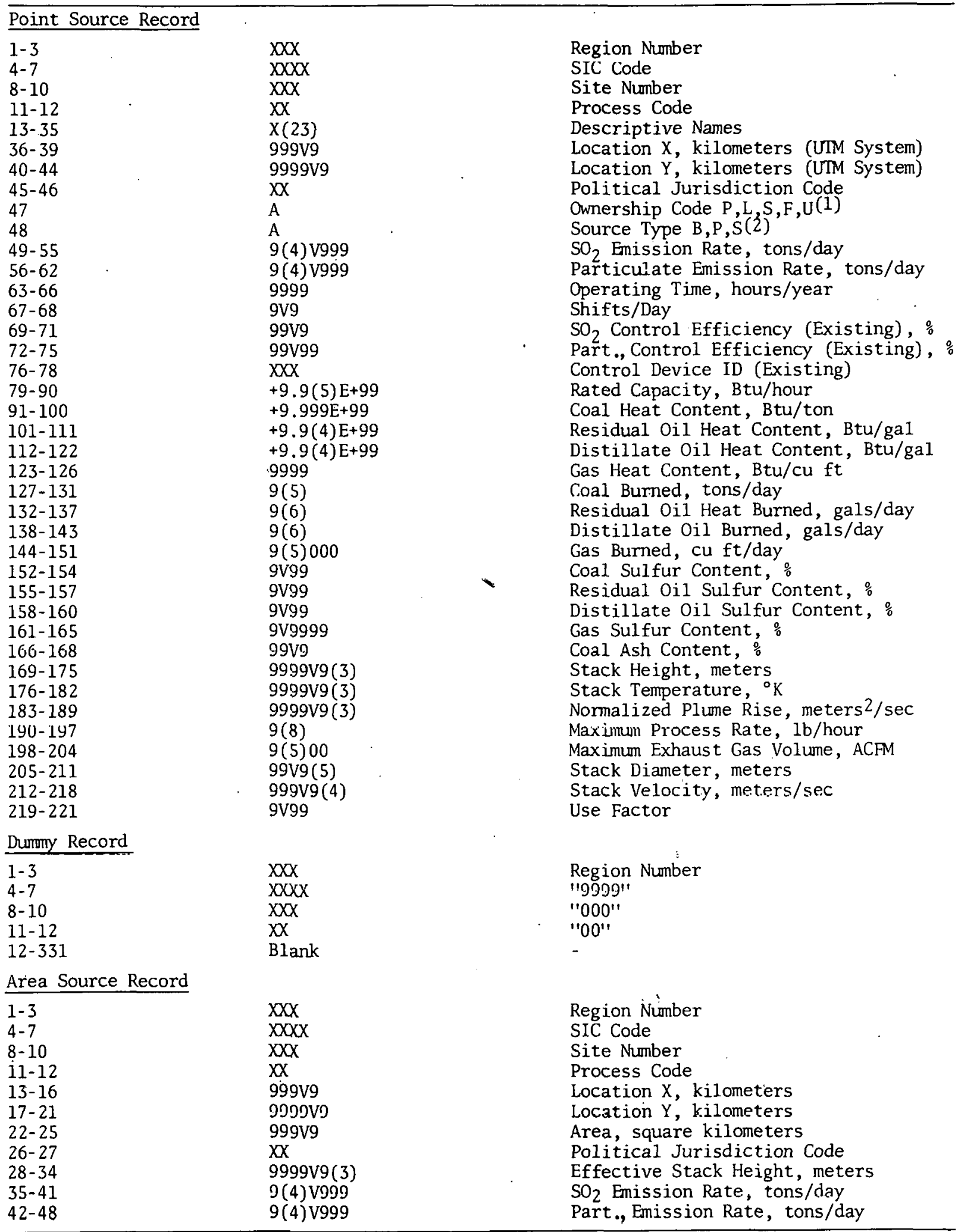

(1)P: Private Ownership; L: Local Government; S: State Government; F: Federal Government; U: Utilities.

(2) B: Fuel Combustion; P: Industrial Process; S: Solid Waste Disposal. 
A complete emission inventory of the pollutants that are considered of episode potential is necessary for the development of effective control strategies. And any survey technique, including Rapid Survey, 3 can be used to develop a complete inventory. Even though most control strategies will probably only affect large point. sources, a complete emission inventory is required in order to determine the effectiveness of a control strategy. For example, if space heating is causing 90 percent of the $\mathrm{SO}_{2}$ problem in a residential area, controlling a fussil-fueled power plant will not materially ease the problem. The importance of having a complete inventory will become more obvious in discussions of the culpable source listings. 


\section{A. Emission Data Lists}

There are many ways of assembling emission data for use in episode control planning. Included in this section are descriptions of five different emission data lists that are helpful in episode control activities. Listings of the computer programs that generate these data lists are contained in Appendix A. The programs are quite simple in design, utilizing a sorting and merging subroutine found in most IBM computer libraries (SORT). Other computer systems that do not have a SORT subroutine package probably have a similar software option. It is not the uniqueness of the computer coding that is important, but the arrangement of data. These programs could be rewritten for any computer with relative ease. 
B. General Source Listing

A complete listing of the emission data for each source is a necessary part of any data file. Other listings will only be reorderings of the sources based upon a particular source parameter, and then the general file will contain all the data that may not be included in other lists. This is the purpose of the general source file (code name GSFILE). It includes a listing of all information in the IPP-2 inventory format that is useful in episode control. A sample General Source File is shown in Table II for the Chicago Metropolitan Air Quality Control Region. The GSFILE listing has been divided into three pages so that the information could be listed on standard $81 / 2 \times 11^{\prime \prime}$ paper for easy handling. There is a great deal of other data in the IPP format that was either considered irrelevant for episode control or difficult to survey, and probably not reliable. Even some of the source parameters that are displayed in the general tile are not avallable (e.g., tuel use data) ợ àrè uñrèliable (e.g., effluent exit velocity). The GSFILE is listed according to source number (assigned by user) on all three pages of data. 
TABLE II. General Source File for Chicago Metropolitan Air Quality Region

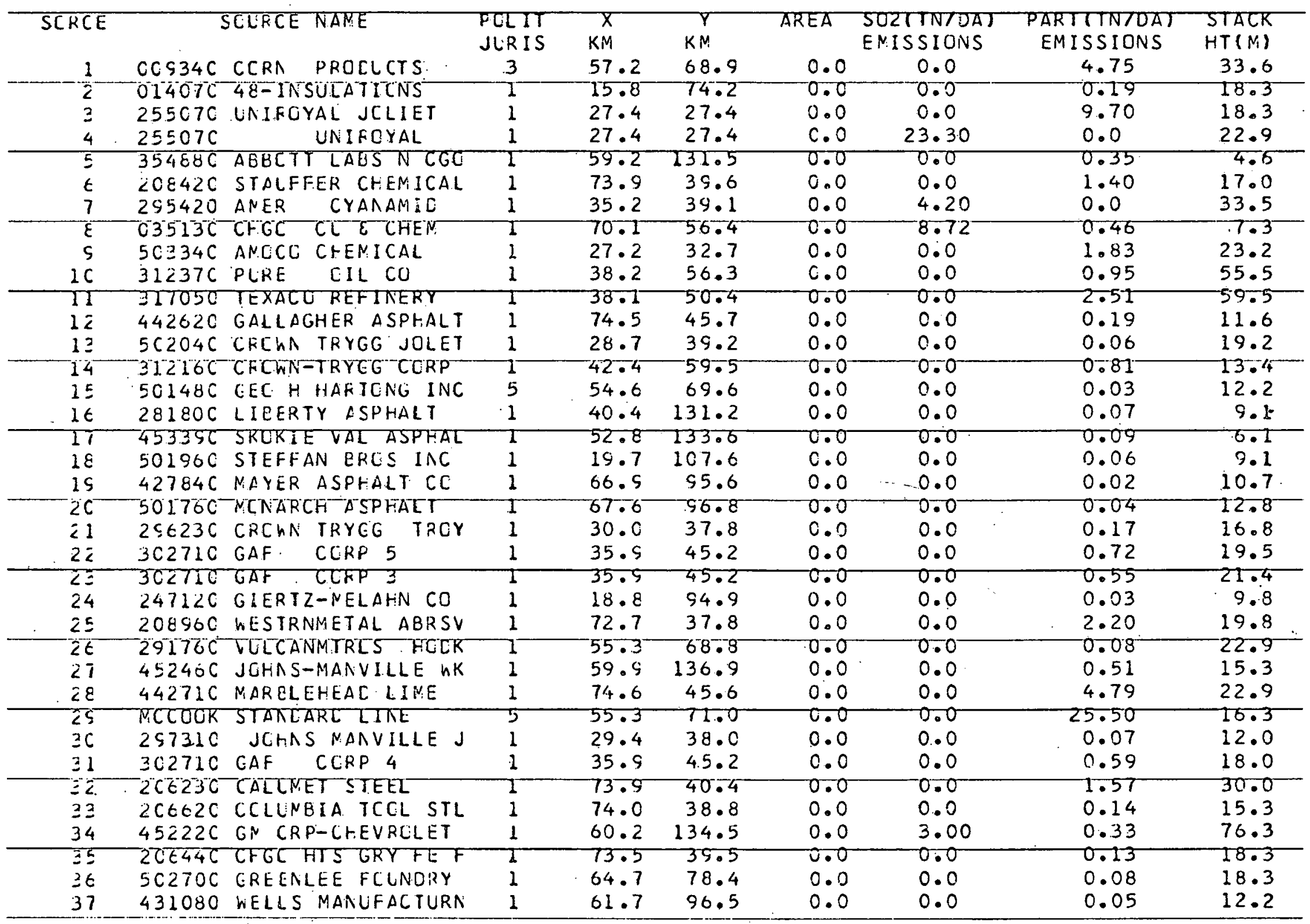


TABLE II (Contd.)

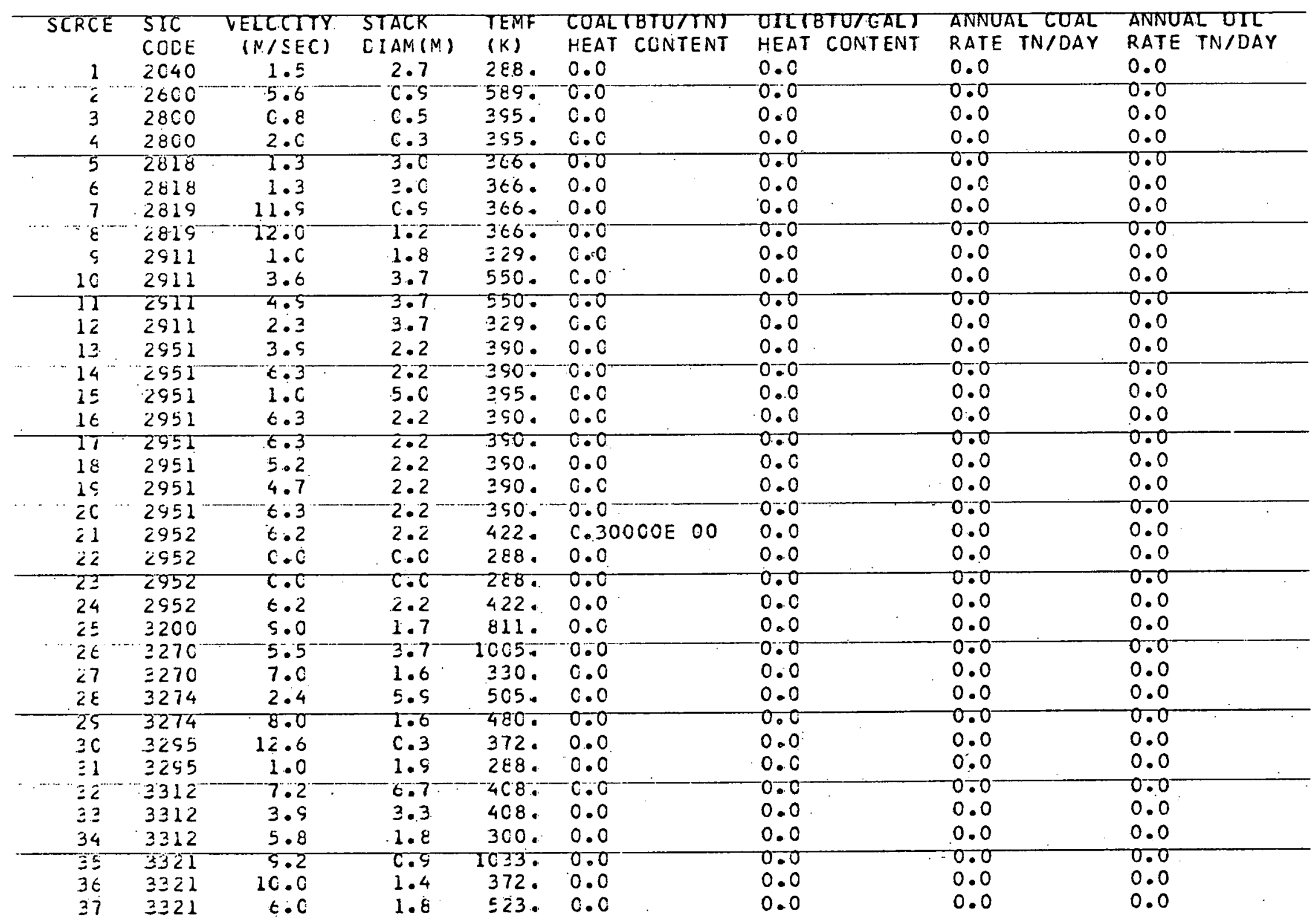


TABLE II. General Source File for Chicago Metropolitan Air Quality Region

\begin{tabular}{|c|c|c|c|c|c|c|c|c|c|c|}
\hline $\begin{array}{c}\text { SORCE } \\
1 \\
\end{array}$ & $\begin{array}{l}\text { PRCCESS } \\
\text { RATE LB/A } \\
\text { C. } 30300 E\end{array}$ & $C E$ & $\begin{array}{l}\text { FERCENT } \\
\text { SULFUR CCAL } \\
\text { C.O }\end{array}$ & $\begin{array}{l}\text { PERCENT } \\
\text { SULF.UR OIL } \\
\text { C.O }\end{array}$ & $\begin{array}{l}\text { EXHAUST } \\
\text { GAS FT } 3 / C \\
0.15400 E\end{array}$ & A & $\begin{array}{l}\text { SUURCE } \\
\text { TYPE } \\
2\end{array}$ & $\begin{array}{l}\text { RATED BTHR } \\
\text { CAPACITY } \\
0 . \text { C }\end{array}$ & $\begin{array}{l}\text { ANINUAL FTSTDA } \\
\text { GAS RATE } \\
0.0\end{array}$ & $\begin{array}{l}\text { GASTE/HTST } \\
\text { HEAT CONTENT } \\
\text { O.O }\end{array}$ \\
\hline $\begin{array}{l}2 \\
3 \\
4\end{array}$ & $\begin{array}{l}C .25000 E \\
C .2 E C 80 E \\
C .7 \text { ICCCE }\end{array}$ & $\begin{array}{l}05 \\
05 \\
05\end{array}$ & $\begin{array}{l}0.0 \\
0.0 \\
0.0\end{array}$ & $\begin{array}{l}C . C \\
0 . C \\
0 . C\end{array}$ & $\begin{array}{l}0.11200 E \\
0.84400 E \\
0.25710 E\end{array}$ & $\begin{array}{l}05 \\
05 \\
06\end{array}$ & $\begin{array}{l}2 \\
2 \\
2\end{array}$ & $\begin{array}{l}0.0 \\
0.0 \\
0.0\end{array}$ & $\begin{array}{l}0.0 \\
0.0 \\
0.0\end{array}$ & $\begin{array}{l}0.0 \\
0.0 \\
0.0\end{array}$ \\
\hline $\begin{array}{l}5 \\
6 \\
7\end{array}$ & $\begin{array}{l}C .6 C 320 E \\
0.24873 E \\
C .1460 C E\end{array}$ & $\begin{array}{l}\text { C5 } \\
C E \\
05\end{array}$ & $\begin{array}{l}0.0 \\
0.0 \\
0.0\end{array}$ & $\begin{array}{l}C .0 \\
C .0 \\
0.0\end{array}$ & $\begin{array}{l}0.5 C C O C E \\
0.20000 E \\
0.17000 E\end{array}$ & $\begin{array}{l}05 \\
05 \\
05\end{array}$ & $\begin{array}{l}2 \\
2 \\
2\end{array}$ & $\begin{array}{l}0.0 \\
0.0 \\
0.0\end{array}$ & $\begin{array}{l}0.0 \\
0.0 \\
0.0\end{array}$ & $\begin{array}{l}0.0 \\
0.0 \\
0.0\end{array}$ \\
\hline $\begin{array}{r}8 \\
9 \\
10\end{array}$ & $\begin{array}{l}C .35668 E \\
C .366 C O E \\
C .262 C 0 E\end{array}$ & $\begin{array}{l}C 5 \\
C .5 \\
C E\end{array}$ & $\begin{array}{l}0.0 \\
0.0 \\
0.0\end{array}$ & $\begin{array}{l}0.0 \\
C .0 \\
0.0\end{array}$ & $\begin{array}{l}0.49000 E \\
0.25000 E \\
0.8 C 000 E\end{array}$ & $\begin{array}{l}05 \\
04 \\
05\end{array}$ & $\begin{array}{l}2 \\
2 \\
2\end{array}$ & $\begin{array}{l}0.0 \\
0.0 \\
0.0\end{array}$ & $\begin{array}{l}0.0 \\
0.0 \\
0.0\end{array}$ & $\begin{array}{l}0.0 \\
0.0 \\
0.0\end{array}$ \\
\hline $\begin{array}{l}11 \\
12 \\
13\end{array}$ & $\begin{array}{l}\text { C. } 28 O S C E \\
C .1 \angle C C O E \\
C .1 \varepsilon C C O E\end{array}$ & $\begin{array}{l}C 7 \\
07 \\
C \in\end{array}$ & $\begin{array}{l}0.0 \\
0.0 \\
0.0\end{array}$ & $\begin{array}{l}c .0 \\
c .0 \\
0.0\end{array}$ & $\begin{array}{l}0.10820 E \\
0.10100 E \\
0.29800 E\end{array}$ & $\begin{array}{l}-07 \\
06 \\
05\end{array}$ & $\begin{array}{l}2 \\
2 \\
2\end{array}$ & $\begin{array}{l}0 . c \\
0 . c \\
0 . c\end{array}$ & $\begin{array}{l}0.0 \\
0.0 \\
0.0\end{array}$ & $\begin{array}{l}0.0 \\
0.0 \\
0.0\end{array}$ \\
\hline $\begin{array}{l}14 \\
15 \\
16\end{array}$ & $\begin{array}{l}C .240 C C E \\
C .2 C C O C E \\
C .4 E C O C E\end{array}$ & $\begin{array}{l}C E \\
C \epsilon \\
c \epsilon\end{array}$ & $\begin{array}{l}0.0 \\
0.0 \\
0.0\end{array}$ & $\begin{array}{l}C .0 \\
C .0 \\
c .0\end{array}$ & $\begin{array}{l}0.40000 E \\
0.27300 E \\
C .80000 E\end{array}$ & $\begin{array}{l}C 5 \\
05 \\
05\end{array}$ & $\begin{array}{l}2 \\
2 \\
2\end{array}$ & $\begin{array}{l}0.0 \\
0.0 \\
0.0\end{array}$ & $\begin{array}{l}0.0 \\
0.0 \\
0.0\end{array}$ & $\begin{array}{l}0: 0 \\
0: 0 \\
0.0\end{array}$ \\
\hline $\begin{array}{l}17 \\
18 \\
19\end{array}$ & $\begin{array}{l}C .4 \pi T C O E \\
C .2 C C O O E \\
C .3 \angle O C C E\end{array}$ & $\begin{array}{l}\text { CE } \\
C t \\
C E\end{array}$ & $\begin{array}{l}0.0 \\
0.0 \\
0.0\end{array}$ & $\begin{array}{l}C .0 \\
C .0 \\
C . C\end{array}$ & $\begin{array}{l}\text { C. } .8 C C O O E \\
0.33 C O O E \\
0.60 C O O E\end{array}$ & $\begin{array}{l}05 \\
05 \\
05\end{array}$ & $\begin{array}{l}2 \\
2 \\
2\end{array}$ & $\begin{array}{l}0.0 \\
0.0 \\
0.0\end{array}$ & $\begin{array}{l}0.0 \\
0.0 \\
0.0\end{array}$ & $\begin{array}{l}0.0 \\
0.0 \\
0.0\end{array}$ \\
\hline $\begin{array}{l}20 \\
21 \\
22\end{array}$ & $\begin{array}{l}C .24000 E \\
C .3 C O C C E \\
C .36880 E\end{array}$ & $\begin{array}{l}C 6 \\
C t \\
0 E\end{array}$ & $\begin{array}{l}0.0 \\
0.0 \\
0.0\end{array}$ & $\begin{array}{l}0.0^{-} \\
c .0 \\
0.0\end{array}$ & $\begin{array}{l}0.40000 E \\
0.47900 E \\
0.15400 E\end{array}$ & $\begin{array}{l}05 \\
05 \\
05\end{array}$ & $\begin{array}{l}2 \\
2 \\
2\end{array}$ & $\begin{array}{l}0.0 \\
0.0 \\
0.0\end{array}$ & $\begin{array}{l}0.0 \\
0.0 \\
0.0\end{array}$ & $\begin{array}{l}0.0 \\
0.0 \\
0.0\end{array}$ \\
\hline $\begin{array}{l}23 \\
24 \\
25\end{array}$ & $\begin{array}{l}C .4748 E E \\
C .3 C C C O E \\
C .3 C C O C E\end{array}$ & $\begin{array}{l}\text { CE } \\
C E \\
C E\end{array}$ & $\begin{array}{l}0.0 \\
0.0 \\
0.0\end{array}$ & $\begin{array}{l}C .0 \\
C .0 \\
C .0\end{array}$ & $\begin{array}{l}0.12500 E \\
0.47900 E- \\
0.27000 E\end{array}$ & $\begin{array}{l}06 \\
-01 \\
05\end{array}$ & $\begin{array}{l}2 \\
2 \\
2\end{array}$ & $\begin{array}{l}0.0 \\
0.0 \\
0.0\end{array}$ & $\begin{array}{l}0.0 \\
0.0 \\
0.0\end{array}$ & $\begin{array}{l}0.0 \\
0.0 \\
0.0\end{array}$ \\
\hline $\begin{array}{l}26 \\
27 \\
28\end{array}$ & $\begin{array}{l}C . C C C C E E \\
C .4 E S 1 C E \\
C .23230 E\end{array}$ & $\begin{array}{l}05 \\
C 5 \\
C E\end{array}$ & $\begin{array}{l}0.0 \\
0.0 \\
0.0\end{array}$ & $\begin{array}{l}C .0 \\
0.0 \\
C .0\end{array}$ & $\begin{array}{l}0.12200 E \\
0.11000 E \\
0.40000 E\end{array}$ & $\begin{array}{l}06 \\
06 \\
06\end{array}$ & $\begin{array}{l}2 \\
2 \\
2\end{array}$ & $\begin{array}{l}0.0 \\
0.0 \\
0.0\end{array}$ & $\begin{array}{l}0.0 \\
0.0 \\
0.0\end{array}$ & $\begin{array}{l}0.0 \\
0.0 \\
0.0\end{array}$ \\
\hline $\begin{array}{l}29 \\
30 \\
31\end{array}$ & $\begin{array}{l}\text { C. } 8 C C C C E \\
C .5 \angle O C C E \\
C .14 E 8 C E\end{array}$ & $\begin{array}{l}05 \\
04 \\
05\end{array}$ & $\begin{array}{l}0.0 \\
0.0 \\
C .0\end{array}$ & $\begin{array}{l}C . C \\
0.0 \\
C .0\end{array}$ & $\begin{array}{l}0.50000 E \\
0.22700 E \\
0.60000 E\end{array}$ & $\begin{array}{l}05 \\
04 \\
04\end{array}$ & $\begin{array}{l}2 \\
2 \\
2\end{array}$ & $\begin{array}{l}0.0 \\
0.0 \\
0.0\end{array}$ & $\begin{array}{l}0.0 \\
0.0 \\
0.0\end{array}$ & $\begin{array}{l}0.0 \\
0.0 \\
0.0\end{array}$ \\
\hline $\begin{array}{l}32 \\
33 \\
34 \\
\end{array}$ & $\begin{array}{l}C .25 C 00 E \\
C .5 C C O C E \\
C .25000 E\end{array}$ & $\begin{array}{l}05 \\
04 \\
05\end{array}$ & $\begin{array}{l}0.0 \\
0.0 \\
0.5\end{array}$ & $\begin{array}{l}0.0 \\
0.0 \\
C .0\end{array}$ & $\begin{array}{l}0.32900 E \\
0.22400 E \\
0.60 C 00 E\end{array}$ & $\begin{array}{l}06 \\
05 \\
05\end{array}$ & $\begin{array}{l}2 \\
2 \\
2\end{array}$ & $\begin{array}{l}0.0 \\
0.0 \\
0.0\end{array}$ & $\begin{array}{l}0.0 \\
0.0 \\
0.0\end{array}$ & $\begin{array}{l}0.0 \\
0.0 \\
0.0\end{array}$ \\
\hline $\begin{array}{l}35 \\
36 \\
37\end{array}$ & $\begin{array}{l}0.1 \angle 000 E \\
0.18470 E \\
C .18892 E\end{array}$ & $\begin{array}{l}\text { C4 } \\
\text { C5 } \\
05\end{array}$ & $\begin{array}{l}0.0 \\
0.0 \\
C .0\end{array}$ & $\begin{array}{l}0.0 \\
0.0 \\
0.0\end{array}$ & $\begin{array}{l}0.19600 E \\
0.22700 E \\
0.17100 E\end{array}$ & $\begin{array}{l}05 \\
05 \\
05\end{array}$ & $\begin{array}{l}2 \\
2 \\
2\end{array}$ & $\begin{array}{l}0.0 \\
0.0 \\
0.0\end{array}$ & $\begin{array}{l}0.0 \\
0.0 \\
0.0\end{array}$ & $\begin{array}{l}0.0 \\
0.0 \\
0.0\end{array}$ \\
\hline
\end{tabular}




\section{C. $\quad$ Source Priority Listing}

II is important for any control agency to know the largest pollution emitters in the control region. A list of such sources, ordered by the magnitude of their emissions for the control region, is useful in determining priorities for control strategies.

Tables III and IV show ordered listings of sources for sulfur dioxide and particulates, respectively. These ordered lists show only the pollutant emission level and source name. If additional source data is required, then, using the source number as a guide, the data can be located in the General Source File. A separate ordered list of polluters can be created for each pollutant. 
TABLE III. SSFILE, Ordered List of $\mathrm{SO}_{2}$ Emitters in Chicago Region

\begin{tabular}{|c|c|c|c|c|}
\hline $\begin{array}{l}157 \\
330 \\
162 \\
283\end{array}$ & $\begin{array}{l}\text { SU2TTKICAT } \\
\text { EMISSICAS } \\
57 C . C 0 \\
375 . C \mathrm{C} \\
316.5 \mathrm{C} \\
3 \mathrm{C} .3 \mathrm{C}\end{array}$ & $\begin{array}{l}\text { PARTTTNIUAT } \\
\text { ENISSICNS } \\
18.50 \\
1.14 \\
12.32 \\
1.1 .21\end{array}$ & $\begin{array}{r}500270 \text { COM EDNEW JOLIET } \\
\text { CON EDTSCN STATE LINE } \\
502300 \text { COM EDWILL CO } 2 \\
\text { CRAWFORD PP }\end{array}$ & $\begin{array}{r}\text { PCLIT } \\
\text { JUR I S } \\
1 \\
6 \\
1 \\
2\end{array}$ \\
\hline $\begin{array}{l}332 \\
160 \\
155\end{array}$ & $\begin{array}{l}267.00 \\
258.00 \\
171.50\end{array}$ & $\begin{array}{l}5.40 \\
16.93 \\
1.30\end{array}$ & $\begin{array}{l}\text { MITCHELL POWER PLANT } \\
500380 \text { COM ED WAUKEGAN } \\
500260 \text { CCM EDOLD JOLIETI }\end{array}$ & $\begin{array}{l}8 \\
1 \\
1\end{array}$ \\
\hline $\begin{array}{l}161 \\
321 \\
382\end{array}$ & $\begin{array}{l}150.01 \\
118.00 \\
116.70\end{array}$ & $\begin{array}{r}6.45 \\
39.88 \\
3.89\end{array}$ & $\begin{array}{l}502300^{\circ} \text { CCM EOWILL COA } \\
\text { US STEEL COALFCR FUEL } \\
\text { FISK PP NEW }\end{array}$ & $\begin{array}{l}1 \\
8 \\
2\end{array}$ \\
\hline $\begin{array}{l}428 \\
381 \\
156\end{array}$ & $\begin{array}{l}96.25 \\
85.80 \\
85.50\end{array}$ & $\begin{array}{r}0.0 \\
1.80 \\
39.00\end{array}$ & $\begin{array}{l}\text { AMOCD WHIT ING. } \\
\text { FISK PP OLD } \\
5 \text { C0260.CCM EDCLD: JCLIET2 }\end{array}$ & $\begin{array}{l}7 \\
2 \\
1\end{array}$ \\
\hline $\begin{array}{l}320 \\
155 \\
280\end{array}$ & $\begin{array}{l}85.50 \\
84.00 \\
68.00\end{array}$ & $\begin{array}{l}3.26 \\
1.88 \\
1.53\end{array}$ & $\begin{array}{l}\text { US STEEL OTL COMBUSTTCN } \\
5 \text { CO2OO COM ED RIDGELANC } \\
\text { ATLANTIC BCILERS }\end{array}$ & $\begin{array}{l}8 \\
1 \\
9\end{array}$ \\
\hline $\begin{array}{l}390 \\
285 \\
391\end{array}$ & $\begin{array}{l}55.58 \\
51.70 \\
47.0 \mathrm{C}\end{array}$ & $\begin{array}{l}57.00 \\
10.40 \\
29.00\end{array}$ & $\begin{array}{l}\text { METRCSANTOI } \\
\text { INLAND STEEL PWR GEN } 401 \\
\text { TAYLCRHCMES }\end{array}$ & $\begin{array}{l}-2 \\
9 \\
2\end{array}$ \\
\hline $\begin{array}{l}219 \\
4 \geq 2 \\
175\end{array}$ & $\begin{array}{l}43 \cdot 3 \mathrm{C} \\
36 \cdot 50 \\
35 \cdot 5 \mathrm{C}\end{array}$ & $\begin{array}{r}34.30 \\
102.00 \\
3.00\end{array}$ & $\begin{array}{l}\text { YNGSTWN S T STEELPL } \\
\text { UNIV ATLAS CEMENT MILL } 6 \\
\text { OC934O CORN PRODUCTS }\end{array}$ & $\begin{array}{l}9 \\
8 \\
3\end{array}$ \\
\hline $\begin{array}{r}421 \\
331 \\
58\end{array}$ & $\begin{array}{l}35.00 \\
28.50 \\
27.40\end{array}$ & $\begin{array}{r}0.0 \\
0.12 \\
38.40\end{array}$ & $\begin{array}{l}\text { DUPONT SULF AC MFG } \\
\text { NIPSCD BURNSHARBCR } \\
\text { JCLIET ARMY ANMO PLANT }\end{array}$ & $\begin{array}{l}9 \\
6 \\
1\end{array}$ \\
\hline $\begin{array}{r}233 \\
419 \\
4\end{array}$ & $\begin{array}{l}24.117 \\
23.70 \\
23.30\end{array}$ & $\begin{array}{l}50.20 \\
0.01 \\
0.0\end{array}$ & $\begin{array}{l}\text { US STEEL ATLASHARBOR } \\
\text { STAUFFER CHEMICAL CO } \\
255070\end{array}$ & 10 \\
\hline $\begin{array}{l}268 \\
427 \\
384\end{array}$ & $\begin{array}{l}22 \cdot 52 \\
22 \cdot 30 \\
22.22\end{array}$ & $\begin{array}{l}3.20 \\
1.20 \\
1.97\end{array}$ & $\begin{array}{l}\text { UNION CARBITELINCE CEMB } \\
\text { ANOCO WHIT FCC CAT REG } \\
\text { CALUNET PP }\end{array}$ & $\begin{array}{l}9- \\
9 \\
2\end{array}$ \\
\hline $\begin{array}{l}194 \\
190 \\
282\end{array}$ & $\begin{array}{l}21 \cdot 36 \\
21 \cdot 20 \\
20.022\end{array}$ & $\begin{array}{r}0.32 \\
35.50 \\
0.16\end{array}$ & $\begin{array}{l}035220 \text { CLARK-REFINERY } \\
255070\end{array}$ & $\begin{array}{l}1 \\
1 \\
9\end{array}$ \\
\hline $\begin{array}{l}271 \\
1<4 \\
157 \\
277 \\
270 \\
281\end{array}$ & $\begin{array}{l}19.00 \\
18.04 \\
17.86 \\
16.70 \\
15.43 \\
13.90\end{array}$ & $\begin{array}{r}6.22 \\
12.58 \\
0.50 \\
0.16 \\
6.17 \\
4.82\end{array}$ & $\begin{array}{l}\text { UNICN CARBICEWHITING CCN } \\
\text { GREAT LAKES TRAIN, CTR } \\
317050 \text { TEXACO REFINERY } \\
\text { MCBIL CIL REFBCILERS } \\
\text { UNION CARBICEPOLYETHYLEN } \\
\text { ANCCO WHIT BCILERS. }\end{array}$ & $\begin{array}{l}7 \\
1 \\
1 \\
9 \\
9 \\
9\end{array}$ \\
\hline $\begin{array}{l}<91 \\
204 \\
423\end{array}$ & $\begin{array}{l}1.3 .6 C \\
12.6 C \\
12.51\end{array}$ & $\begin{array}{l}0.0 \\
1.11 \\
0.0\end{array}$ & $\begin{array}{ll}\text { INLANO STEEL COKE OVN } \\
\text { INLANC STEEL } 80 \text { STRIP ML } \\
\text { ATLANTIC } & \text { FCC STRIP }\end{array}$ & $\begin{array}{l}9 \\
9 \\
9\end{array}$ \\
\hline $\begin{array}{l}293 \\
274 \\
271\end{array}$ & $\begin{array}{l}17.74 \\
11.40 \\
11.25\end{array}$ & $\begin{array}{l}0.0 \\
0.0 \\
12.45\end{array}$ & $\begin{array}{ll}\text { INLAND STEEL OPN HRTH } \\
\text { ATLANTIC } & \text { GAS CEA ABS } \\
10625 & \text { CANPBELLS }\end{array}$ & $\begin{array}{l}9 \\
9 \\
2\end{array}$ \\
\hline $\begin{array}{r}295 \\
424 \\
239 \\
196 \\
8 \\
277\end{array}$ & $\begin{array}{l}10 \cdot 30 \\
1 C .0 .0 \\
10.00 \\
5.70 \\
\varepsilon .72 \\
\varepsilon .70\end{array}$ & $\begin{array}{r}0.33 \\
0.0 \\
10.52 \\
0.53 \\
0.46 \\
3.39\end{array}$ & $\begin{array}{ll}\text { TNLANO-STEET MHLS } \\
\text { ANOCO WHIT } & \text { SULF REC } \\
10725 & \text { CENTRALSOYA } \\
312370-P U F E & \text { EIL CO } \\
025130 \text { CHGO } & \text { CUE CHEM } \\
31974 & \text { INTERNATHAR }\end{array}$ & $\begin{array}{l}9 \\
9 \\
2 \\
1 \\
1 \\
2\end{array}$ \\
\hline
\end{tabular}


TABLE IV. PSFILE, Ordered List of Particulate Emitters in Chicago Region

\begin{tabular}{|c|c|c|c|c|}
\hline SCRCE & $\begin{array}{l}\text { SC2TTINCA) } \\
\text { ENISSICNS } \\
36.5 C\end{array}$ & $\begin{array}{l}\text { PARTTTKTOAI } \\
\text { EMISSICNS } \\
102.00\end{array}$ & UNIV ATLAS CENENT MILL 6 & $\begin{array}{l}\text { PLLIT } \\
\text { JURIS } \\
8\end{array}$ \\
\hline $\begin{array}{l}435 \\
449 \\
105\end{array}$ & $\begin{array}{l}0.0 \\
0.0 \\
0.0\end{array}$ & $\begin{array}{l}85.50 \\
64.40 \\
59.26\end{array}$ & $\begin{array}{l}\text { US STEEL OPENHEARTHS } \\
\text { US STEEL SINTERING PLANT } \\
63857\end{array}$ & $\begin{array}{l}8 \\
8 \\
2\end{array}$ \\
\hline $\begin{array}{l}390 \\
433 \\
321\end{array}$ & $\begin{array}{r}55.58 \\
24.11 \\
118.00\end{array}$ & $\begin{array}{l}57.00 \\
50.20 \\
35.88\end{array}$ & $\begin{array}{l}\text { METRLSANTUI } \\
\text { US STEEL ATLASHARBOR } \\
\text { US STEEL COALFOR FUEL }\end{array}$ & $\begin{array}{l}2 \\
8 \\
8\end{array}$ \\
\hline $\begin{array}{r}156 \\
58 \\
190\end{array}$ & $\begin{array}{l}89 \cdot 50 \\
27 \cdot 40 \\
21 \cdot 20\end{array}$ & $\begin{array}{l}39.00 \\
38.40 \\
35.50\end{array}$ & $\begin{array}{l}500260 \text { CON EDCLO JOLIETZ } \\
\text { JCLIET ARMY ANNO PLANT } \\
255070 .\end{array}$ & $\begin{array}{l}7 \\
1 \\
1\end{array}$ \\
\hline $\begin{array}{l}319 \\
106 \\
107\end{array}$ & $\begin{array}{l}43.30 \\
c .0 \\
0.0\end{array}$ & $\begin{array}{l}34.30 \\
32.90 \\
30.14\end{array}$ & $\begin{array}{ll}\text { YNGSTWN S T STEEL PL } \\
63857 & \text { USSTEEL } \\
63857 & \text { USSTEEL }\end{array}$ & $\begin{array}{l}9 \\
2 \\
2\end{array}$ \\
\hline $\begin{array}{r}57 \\
391 \\
29\end{array}$ & $\begin{array}{l}0.0 \\
47.00 \\
0.0\end{array}$ & $\begin{array}{l}30.00 \\
29.00 \\
25.50\end{array}$ & $\begin{array}{l}\text { MCCOCK MATERTAL SERVICE } \\
\text { - TAYLCRHCMES } \\
\text { MCCOCK STANCARL. LINE }\end{array}$ & $\begin{array}{l}5 \\
2 \\
5\end{array}$ \\
\hline $\begin{array}{l}441^{-} \\
113 \\
414\end{array}$ & $\begin{array}{l}0.0 \\
0.0 \\
0.0\end{array}$ & $\begin{array}{l}20.60 \\
20.55 \\
19.70\end{array}$ & $\begin{array}{l}\text { INLAND STEEL OP HPL } 2 \\
31975 \\
\text { OHARE AIRPUKTJET PLANES }\end{array}$ & $\begin{array}{l}9 \\
2 \\
2\end{array}$ \\
\hline $\begin{array}{l}157 \\
160 \\
100\end{array}$ & $\begin{array}{l}570.00^{-} \\
258.00 \\
6.0\end{array}$ & $\begin{array}{l}18.50 \\
16.9 .3 \\
14.56\end{array}$ & $\begin{array}{l}500270 \text { COM EONEW JOLIET- } \\
500380 \text { COM ED WAUKEGAN } \\
31735 \\
\text { INTERLAKE }\end{array}$ & $\begin{array}{l}1 \\
1 \\
2\end{array}$ \\
\hline $\begin{array}{l}103 \\
1 \in 4 \\
371\end{array}$ & $\begin{array}{l}0.0 \\
18.04 \\
11.25\end{array}$ & $\begin{array}{l}12.60 \\
12.58 \\
12.45\end{array}$ & $\begin{array}{ll}52455 & \text { REPUELICST } \\
\text { GREAT LAKES } & \text { TRAIN,CTR: } \\
10625 & \text { CAMPBELLS }\end{array}$ & $\begin{array}{l}2 \\
1 \\
2\end{array}$ \\
\hline $\begin{array}{r}162 \\
49 \\
105\end{array}$ & $\begin{array}{l}3 I E .50 \\
0.0 \\
0.0\end{array}$ & $\begin{array}{l}12.32 \\
12.10 \\
11.64\end{array}$ & $\begin{array}{l}502300 \text { COM EDAILLCO } \\
\text { MCCCOK REYNOLOS METALS } \\
52455\end{array}$ & $\begin{array}{l}1 \\
5 \\
2\end{array}$ \\
\hline $\begin{array}{l}440 \\
383 \\
339\end{array}$ & $\begin{array}{l}0.0 \\
303.30 \\
10.00\end{array}$ & $\begin{array}{l}11.30 \\
11.21 \\
10.52\end{array}$ & $\begin{array}{ll}\text { INLAND STEEL COKING PL } \\
\\
10725 & \text { CRAWFORD PP } \\
\text { CENTRALSOYA }\end{array}$ & $\begin{array}{l}9 \\
2 \\
2\end{array}$ \\
\hline $\begin{array}{r}289 \\
443 \\
3\end{array}$ & $\begin{array}{l}51 \cdot 7 \mathrm{C} \\
0.0 \\
0.0\end{array}$ & $\begin{array}{r}10.40 \\
10.40 \\
5.70\end{array}$ & $\begin{array}{l}\text { INLANO STEEL PHR GEN } 401 \\
\text { US STEEL BLAST FURNACE I } \\
255070 \text { UNIRTYYI JNI IFT }\end{array}$ & $\begin{array}{l}-9 \\
8 \\
1\end{array}$ \\
\hline $\begin{array}{l}104 \\
350 \\
111\end{array}$ & $\begin{array}{l}C .0 \\
5.88 \\
C .0\end{array}$ & $\begin{array}{l}8.51 \\
6.86 \\
6.58\end{array}$ & $\begin{array}{ll}52455 & \text { REPUELIC ST } \\
41140 & \text { MARBLIHEAD } \\
31975 & \text { WISCONSINST }\end{array}$ & $\begin{array}{l}-2 \\
2 \\
2\end{array}$ \\
\hline $\begin{array}{r}161 \\
57 \\
271\end{array}$ & $\begin{array}{c}150.01 \\
c .0 \\
15.00\end{array}$ & $\begin{array}{l}6.45 \\
6.40 \\
6.22\end{array}$ & $\begin{array}{l}502300 \text { COM EDWTLL CO } 1 \\
500100 \text { METRO SANI DIST } \\
\text { UAICN CARBICLWIITING COM }\end{array}$ & $\begin{array}{l}1 \\
1 \\
7\end{array}$ \\
\hline $\begin{array}{l}270 \\
110 \\
232\end{array}$ & $\begin{array}{c}15.43 \\
0.0 \\
267.00\end{array}$ & $\begin{array}{l}6.17 \\
5.92 \\
5.40\end{array}$ & $\begin{array}{l}\text { UNION CAKBTCEPULYETHYLEN } \\
31975 \text { WISCONSINST } \\
\text { MITCHELL POWER PLANT. }\end{array}$ & $\begin{array}{l}9 \\
2 \\
8\end{array}$ \\
\hline $\begin{array}{r}338 \\
281 \\
28\end{array}$ & $\begin{array}{r}4.68 \\
13.9 C \\
0.0\end{array}$ & $\begin{array}{l}4.97 \\
4.82 \\
4.79\end{array}$ & $\begin{array}{l}17320 \text { DARLITG ECO } \\
\text { ANCCO WHIT BCILERS } \\
442710 \text { MARBLEHEAD LIME }\end{array}$ & $\begin{array}{l}2 \\
9 \\
1\end{array}$ \\
\hline $\begin{array}{r}1 \\
102 \\
95\end{array}$ & $\begin{array}{l}0.0 \\
0.0 \\
0.0\end{array}$ & $\begin{array}{l}4.75 \\
4.66 \\
4.38\end{array}$ & $\begin{array}{ll}\text { OC9340 CORN } & \text { PROOUCTS } \\
52455 & \text { REPUELIC ST } \\
41140 & \text { MARBLEHEAD }\end{array}$ & $\begin{array}{l}3 \\
2 \\
2\end{array}$ \\
\hline $\begin{array}{r}58 \\
69 \\
372\end{array}$ & $\begin{array}{l}0.0 \\
0.0 \\
2.57\end{array}$ & $\begin{array}{l}4.33 \\
4.25 \\
4.00\end{array}$ & $\begin{array}{l}\text { INTERLAKE } \\
\text { CARGILL } \\
\text { GLIDDEN CO }\end{array}$ & $\begin{array}{l}-2 \\
2 \\
2\end{array}$ \\
\hline
\end{tabular}


D. Jurisdictional Ordering

The previously described listing orders sources by emission rate for the entire air quality control region. However, most air quality control regions have several local governing structures that have separate air pollution control agencies. An example would be the Chicago Metropolitan Air Quality Control Region, which has at least eleven jurisdictions in the Chicago Region with control agencies. The U. S. Environmental Protection Agency would, of course, want to know the largest problems in each of the jurisdictions for effective control. States and counties would also want to know the largest sources within their aggregated jurisdiction.

For this reason an ordered list of source emissions using a breakdown by jurisdiction and pollutant has been formed. Tables V and VI show jurisdictional listings for sulfur dioxide and particulates for the Chicago Region. The jurisdiction number is keyed to the number found in Table VII. 
TABLE V. SJFILE, Ordered List of $\mathrm{SO}_{2}$ Emitters

in Chicago Region, according to Jurisdiction

\begin{tabular}{|c|c|c|c|c|}
\hline SCRCE & $\begin{array}{l}S O 2(T N / C A) \\
E N I S S I C A S\end{array}$ & $\begin{array}{c}\text { PART (TN/CA) } \\
\text { EMISSICAS }\end{array}$ & SOURCE NAME & $\begin{array}{l}\text { PCLIT } \\
\text { JURIS }\end{array}$ \\
\hline 157 & 570.00 & $18.50^{-}$ & $5 \operatorname{CO} 270$ COM EDNEW JOLIET & 2 \\
\hline $16 . \bar{z}$ & $31 t .50$ & 12.32 & $5 C 2300$ CON EDHILL CO 2 & 1 \\
\hline $16 C$ & $258 \cdot C C$ & 16.93 & 500380 COM ED WAUKEGAN & 1 \\
\hline 155 & $171 \cdot 5 \mathrm{C}$ & 1.30 & 500260 CON EUCLD JOLIETI & I \\
\hline 161 & $15 \mathrm{C} \cdot 01$ & 6.45 & 502300 CCM EOWILL CO 1 . & 1 \\
\hline 156 & $89.5 C$ & 39.00 & 500260 CCM EDOLD JOLIET 2 & 1 \\
\hline 155 & $84 . \mathrm{CC}^{-}$ & 1.88 & $5 \mathrm{CO} 200 \mathrm{COM}$ ED RTDGELAND & 1 \\
\hline 58 & 27.40 & 38.40 & JCLIET ARNY ANMO PLANT & 1 \\
\hline 4 & $23.3 \mathrm{C}$ & $c .0$ & UNIRCYAL & 1 \\
\hline .194 & $21 \cdot 36$ & C.32 & $035 \angle 20$ CLARK REF INERY & 1 \\
\hline 190 & 21.20 & 35.50 & $255070 \quad$ UNINCYAL & 1 \\
\hline $1 \in 4$ & 18.04 & $1 \ddot{.} \cdot \Delta E$ & GREAT LAKES TKAIN,CTR. & 1 \\
\hline 197 & 77.86 & $0.50^{-}$ & 317050-TEXACO-REFINERY & 1 \\
\hline 196 & 5.70 & 0.53 & 312370 PURE CIL CO & 1 \\
\hline 8 & 8.72 & 0.46 & $035130 \mathrm{CHGO}$ CU $\&$ CHEM & 1 \\
\hline 184 & $E . S 1$ & 0.85 & उE4880 ABLOTT $[A B S \times C G O$ & 1 \\
\hline 150 & 5.92 & 0.34 & 312170 ARGCNNE NATL LABS & 1 \\
\hline 206 & $E . \varepsilon C$ & C.\$2 & 286030 WYMAN-GCRDCN CO. & 1 \\
\hline 136 & 5.56 & 0.45 & 295900 CATERPTLLAAK & 1 \\
\hline 202 & 5.25 & 3.19 & 3C2710 GAF CORP 1 COAL & 1 \\
\hline 169 & 4.56 & $1.5 t$ & 5C8940 ELGIN STATE HOSP & 1 \\
\hline 7 & 4.20 & 0.0 & 295420 AMER CYANAMTO & 1 \\
\hline 122 & 3.85 & 1.23 & $453570 \mathrm{U} . \mathrm{S}$. STEEL CORP & 1 \\
\hline 34 & $3 \cdot \mathrm{Co}$ & 0.33 & 452220 GM CRP-CHEVRCLET & 1 \\
\hline $17 c^{-}$ & $\hat{2} \cdot 8 \varepsilon$ & $0.8 \varepsilon$ & $507980^{-}$STATE=VILLE PEN. & 1 \\
\hline 142 & 2.75 & 0.02 & 2CGS50 FCRD MCTGR CO & 1 \\
\hline 165 & 2.46 & 0.31 & FI.SHERICAN & 1 \\
\hline $2 \mathrm{CO}$ & 1.89 & 2.13 & 452460 JCHNS-MANVILLE WK & 1 \\
\hline 182 & 1.82 & 0.25 & 2C8420 STAUFFER CHEMICAL & 1 \\
\hline 172 & 1.69 & 1.05 & 247630 KERBER PACK ING CO & 1 \\
\hline 173 & 1.45 & 0.02 & 448530 OVALTINE FCOD-PRO- & 1 \\
\hline 158 & 1.41 & C. $4 t$ & 5C7SOO WINNETKA MLN ELEC & 1 \\
\hline 140 & 1.37 & 0.97 & 461970 WOODSTOCK DIECAST & 1 \\
\hline 131 & 1.30 & $0.07^{-}$ & 303220 US STEEL & 1 \\
\hline 204 & $1 . \mathrm{CO}$ & 0.32 & 41E170 MOLINE-MALLEABLE & 1 \\
\hline 145 & C. .56 & 0.30 & 298090 LENNCNWALL PAPER & 1 \\
\hline 128 & $C .82$ & $0.3 .0^{-}$ & $452280-$ GRISS-PFLEGER TAN & $1^{-}$ \\
\hline 177 & C. .77 & 0.06 & O12420 AURORA PAPERBCARD & 1 \\
\hline 142 & 0.66 & 0.12 & 458850 GM FISHER BOCY & 1 \\
\hline 327 & 0.60 & $0.0,3$ & D26940 STANLATRD SCREW CO & 1 \\
\hline 207 & C. 56 & 0.05 & 430600 TELE IYPE CORP & 1 \\
\hline 168 & C. 55 & 0.38 & 037710 RCSSI \& SCNS & 1 \\
\hline 185 & $C .4=$ & $c .04$ & 429940 SEAREE \& CC & 1 \\
\hline 1SS & 0.38 & 0.02 & 206350 CERTAIN-TEED & 1 \\
\hline 149 & c. .37 & 0.03 & 285790 SINCLAIR RFSFARCH & 1 \\
\hline ादक्ष & 0.35 & $0.0 \mathrm{~L}$ & $505160-$ TRUMBUL ASPHALT & 1 \\
\hline 181 & 0.35 & 0.05 & 321700 SMITH CHEMICAL WK & 1 \\
\hline 133 & C. 35 & 0.04 & $4.524 S O$ JOHNSON MOTORS & 1 \\
\hline 130 & 7.32 & 0.35 & 355240-FANSTEEL MTLCCORP- & 1 \\
\hline 205 & $c .32$ & 0.05 & $2 C E 620$ COLUMBIA TCOL STL & 1 \\
\hline 183 & $\mathrm{C} \cdot 3 \mathrm{C}$ & 0.21 & 454380 AMER PCTASH CCRP & 1 \\
\hline 129 & C.2G & 0.03 & $24571 C$ CHICAGC RATHICE & 1 \\
\hline
\end{tabular}


TABLE VI. PJFILE, Ordered List of Particulate Emitters in Chicago Region, according to Jurisdiction

\begin{tabular}{|c|c|c|c|c|}
\hline SCRCE & $\begin{array}{l}\text { SO2 (TN/CA) } \\
\text { EMISSICNS }\end{array}$ & $\begin{array}{c}\text { PART (TN/DA) } \\
\text { EMISSICNS }\end{array}$ & SOURCE NAME & $\begin{array}{l}\text { PCL IT } \\
\text { JURIS }\end{array}$ \\
\hline 156 & 85.50 & $39.00^{-}$ & $500260^{\circ}$ CCM. EDOLD JOLTET2 & 1 \\
\hline 58 & 27.40 & 38.40 & JOLIET ARMY ANMO PLANT & 1 \\
\hline 190 & 21.20 & 35.50 & UNIRUYAL & 1 \\
\hline 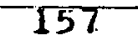 & 570.00 & $18.50^{\circ}$ & $5 C 0270$ CCM EDNEK JULIET & 1 \\
\hline 160 & $258.0 \mathrm{C}$ & 16.93 & $50 C 380$ COM EO HAUKEGAN & 1 \\
\hline 164 & 18.04 & 12.58 & GREAT LAKES TRAIN,CTR. & 1 \\
\hline 162 & 316.50 & 12.32 & $502300 \mathrm{COM}$ EDWILL CO- & $I$ \\
\hline 3 & 0.0 & 9.70 & 255070 UNIROYAL JOLIET & 1 \\
\hline 161 & 150.01 & 6.45 & 502300 COM EOWILL CO 1 & 1 \\
\hline 57 & 0.0 & 6.40 & 500100 METRO SANI DIST & 1 \\
\hline 28 & $c .0$ & 4.79 & MARBLEHEAD LIME & 1 \\
\hline 202 & 5.25 & 3.19 & 302710 GAF CORP I COAL & 1 \\
\hline 141 & $C \cdot C$ & 3.01 & 502900 WESTRTN ELECTRIC & 1 \\
\hline 11 & 0.0 & 2.51 & 317050 TEXACO REFINERY & 1 \\
\hline 25 & C. $\mathrm{C}$ & 2.20 & 208960 WESTRNMETAL ABRSV & 1 \\
\hline $200^{\circ}$ & 1.8 .9 & 2.13 & 452460 JUANS $\equiv$ MANVILLE WK & 1 \\
\hline 159 & 84.00 & 1.88 & $5 C 0200$ COM ED RIDGELAND & 1 \\
\hline 9 & 0.0 & 1.83 & 503340 AMOCO CHEMICAL & 1 \\
\hline 44 & $\mathrm{C} \cdot \mathrm{C}^{-}$ & 1.66 & 205870 ABEX CDRP & 1 \\
\hline 32 & C. 0 & 1.57 & 206230 CALUMET STEEL & 1 \\
\hline 169 & 4.56 & 1.56 & $5 C 8940$ ELGIN STATE HOSP & 1 \\
\hline 6 & $c .0$ & 1.40 & 2 C8420 STAUTFFER CHEMICAL & 1 \\
\hline 50 & C. 10 & 1.39 & 207220 BENJ HARRIS CC & 1 \\
\hline 155 & .171 .50 & 1.30 & $5 C C 260$ COM EUCLD JOLIETL & 1 \\
\hline 132 & 3.85 & 1.23 & 453570 U.S. STEEL CORP & 1 \\
\hline 172 & 1.69 & 1.05 & 247630 KERBER PACKING CO & 1 \\
\hline 140 & 1.37 & c. 97 & 461970 HOCOSTOCK DIECAST & 1 \\
\hline 10 & 0.0 & 0.9 .5 & 312370 PURE OLL CO & $\boldsymbol{T}$ \\
\hline 208 & 5.80 & c. 92 & 286030 WYMAN-GGRDCN CO & 1 \\
\hline 38 & 0.0 & 0.91 & O28770 CLOW ESONS INC & 1 \\
\hline 170 & 2.88 & 0.88 & $507980^{-}$STATE-VILLE PEN. & 1 \\
\hline 184 & $t . S 1$ & 0.85 & 354880 ABBOTT LABS N CGO & 1 \\
\hline 14 & 0.0 & 0.81 & 312160 CRGNN-TRYGG CORP & 1 \\
\hline 22 & 2.0 & 0.72 & 302710 GAF CORP 5 & $T$ \\
\hline 171 & C.1C & 0.71 & 508000 JULIETSTATE PEN. & 1 \\
\hline 54 & C. 0 & 0.68 & 452490 JOHNSON MOTORS & 1 \\
\hline 48 & 0.0 & $0.60^{\circ}$ & $014880 \mathrm{~W} F \mathrm{JJBBTNS} \mathrm{CO}^{-}$ & $T$ \\
\hline 31 & C. 0 & C. 59 & 302710 GAF CORP 4 & 1 \\
\hline 23 & $\mathrm{C} \cdot \mathrm{O}$ & 0.55 & 302710 GAF & 1 \\
\hline 196 & 5.70 & 0.53 & 312370 PURE OIL CO & $T$ \\
\hline 27 & C.C & 0.51 & 452460 JOHNS-MANVILLE WK & 1 \\
\hline 43 & 0.0 & C. 50 & 416170 MOLINE-NALLEABLE & 1 \\
\hline 197 & $17 . \varepsilon E$ & $0.50^{-}$ & $377050^{-}$TEXACO REF INERY & 1 \\
\hline 158 & 1.41 & $c .46$ & 507900 WINNETKA MUN ELEC & 1 \\
\hline 8 & $\varepsilon .72$ & 0.46 & $035130 \mathrm{CHGO}$ CU \& CHEM & 1 \\
\hline 136 & 5.56 & 0.45 & 255900 CATERPILLAAR & 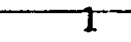 \\
\hline 168 & 0.5 .5 & 0.38 & 037710 ROSSI $\varepsilon$ SCNS & 1 \\
\hline 94 & C. 0 & 0.36 & 208000 OWENS ILLINOIS & 1 \\
\hline 5 & 0.0 & 0.35 & $354880^{-} A B B$ BT T LABS N CGO & 1 \\
\hline 130 & 0.33 & 0.35 & 3bל240 FANSTEEL MTL CORP & 1 \\
\hline 150 & 5.52 & 0.34 & 312170 AKGGONNE NATL LABS & 1 \\
\hline 34 & 3.00 & 0.33 & 452220 GM CRP=CHEVRDEET & 1 \\
\hline
\end{tabular}


TABLE VII. Political Júrisdiction

Key for Chicago Metropolitan Air Quality Control Region

1. Slute of IllinniE

2. Chicago, Illinols

3. Bedford Park, T11.inuis

4. Morton Grove, Illinois

5. McCook, Illinois

6. State of Indiana

7. Lake County, Indiana

8. Gary, Indiana

9. East Chicago, Indiana

10. Hanmond, Indiana

11. Cook County, Illinois 
E. Single Source Tables Listing

In planning emergency control strategies, the individual effects of single sources must be identified. A convenient method for determining the effects of singular sources is use of the Isopleth Area Tables. ${ }^{4}$ These tables represent a single-source dispersion model in tabular form. A source listing (ordered by source number) provides information for using the Isopleth Area Tables. Table VIII is a sample listing for the Chicago Region. In this table the emissions are given in $\mathrm{lb} / \mathrm{hr}$ because this is the dimension used in the Isopleth Area Tables. The physical stack height and heat output are also given, so that the "effective stack height" can be calculated for any source. 
TABIE VIII. TFILE. Source Log fcr Isopleth-area Tables; Chicago Region

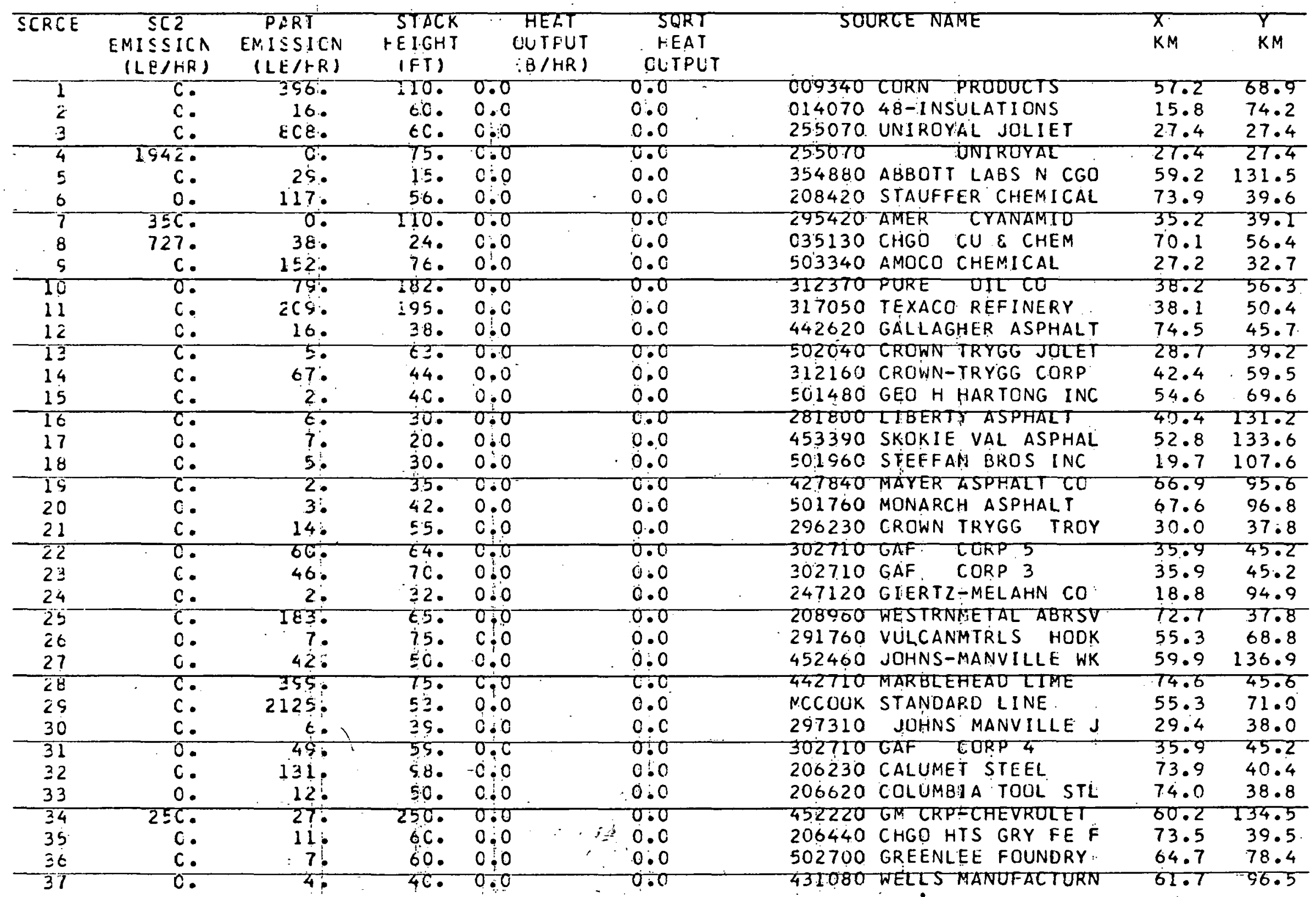




\section{F. Area Source Locations}

When certain areas within an air quality control region produce high pollutant levels and it does not appear obvious that a singular large source, or sources upwind from the receptor, are causing the problem, then the strategist should probably look at the sources in the immediate vicinity of the receptor. A grouping of sources by their location (X,Y coordinates) may be performed by a simple primary and secondary search on the $\mathrm{X}$ and Y coordinates. 


\section{DISPERSION ANALYSIS}

An important part of episode control is predicting the dispersion of pollutants when poor meteorological conditions prevail. Since almost all episodes occur when non-typical meteorological conditions dominate an urban region, episode strategies or planning methodologies should be oriented to these abnormal meteorological conditions. A dispersion model is utilized in this episode planning methodology to precalculate pollutant distributions for probable episode meteorological conditions. These preplanned contours are then used to develop effective and efficient emergency control strategies.

The dispersion model recommended by the U.S. Environmental Protection Agency is the Air Quality Display Model (AQDM) developed by TRW Systems for the EPA, Office of Air Programs (OAP). This model was developed so that state and local agencies would have a dispersion modeling tool available when they assembled their implementation plans. Therefore, AQDM is oriented toward annual emissions and annual air quality averages and can only calculate shortertime air quality levels utilizing statistical techniques. This type of dispersion modeling as it stands is totally inadequate for episode control planning. The "ideal" dispersion model for episode control is the integrated PUFF mode1. 5 This model utilizes a Lagrangian view of plumes, and therefore allows the observer to follow the "puff" of pollutant through changes in wind direction and wind speed. However, this model has two disadvantages for preplanning episode control. First, there are so many possible episode conditions and changes in conditions that it would be extremely costly in terms of computer time and manpower spent on input setup. Second, and probably more important, is the fact that the program is not oriented toward episode strategy development; 
and a great deal of program modification would be required to overcome this disadvantage. The capabilities of the integrated PUFF model are best utilized as an episode evaluation tool or for accidents and spills, both of which take advantage of the ability of the PUFF system to follow the dynamics of a plume. A simple model, both computationally and operationally, is a steadystate Gaussian plume model developed for episode strategy planning. Although the steady-state Gaussian formulation is not applicable to all situations, it has proven to be as accurate as the PUFF model under certain conditions. It of course must be understood by the user that the steady-state formulation assumes infinite time, and this is unrealistic. Therefore the outputs must be examined very carefully.

There are many steady-state Gaussian plume models available, including several at Argonne National Laboratory. However, the AQDM program is the federally accepted dispersion program and it has a basic Gaussian plume algorithm; hence, it was decided that this model would be the starting point for developing an episode strategy dispersion model. The AQDM model has two other features that make it a more universally useful tool for episode planning. First, the input format for source emissions is the IPP standard inventory format, and sernnd, the conrdinate system used is the Universal Transverse Mercator (UTM) system; both of these are used throughout the country.

In the process of developing a useful dispersion program for episode control planning, it became evident that there were many parts of the AQDM program that, while presenting no difficulty when used in the context of annual statistics and calibration, showed serious drawbacks for individual sets of meteorological conditions. It is popularly known from past experience that the AQDM model overpredicts air pollution levels by a factor of two to three. When 
calibration is used in the case of the annual average operation of the AQDM program, the overprediction of air pollution can be regressed to quasirealistic values. Several changes were made to the AQDM dispersion program to produce more accurate air quality predictions in the absence of its regression bias of calculated air quality. The major changes and their effect on air quality calculations are described in greater detail in this chapter. A more complete discussion of the AQDM steady-state Gaussian formulation can be found in the program writeup ${ }^{1}$ or D.B. Turner's handbook ${ }^{6}$ on atmospheric dispersion. 
A. Argonne Steady State Mode1 (ASSM)

This model is a Gaussian plume dispersion model that calculates air quality levels for single sets of meteorological conditions. The chief outputs are: regional air quality contours; receptor air quality levels; and source culpability lists. The outputs from this model are discussed in Chapter $\mathrm{V}$ with the entire methodology for episode strategy analysis. Sulfur dioxide and particulates are the two pollutants handled by ASSM, but air quality levels for any non-reacting pollutant could be calculated using this model.

The ASSM program, as stated previously, utilizes most of the AQDM dispersion model; however, several significant changes were made to the program. These changes are described in the following sections. 
B. Plume Rise

Estimates of plume rise are required to predict the dispersion of pollutants from sources having a large buoyancy or a high stack exit velocity. The use of emissions above their stack height can account for a sizeable reduction in the pollutant concentrations calculated at the ground. A recent analysis of plume rise observations by G. A. Briggs ${ }^{7}$ suggests a formulation that predicts plume rise very well. This work was recently presented in a critical review ${ }^{8}$ he performed for the Atomic Energy Commission. The expression for plume rise, $\Delta \mathrm{h}$, is given by

$$
\begin{gathered}
\Delta h=1,6 \mathrm{~F}^{1 / 3} \mathrm{u}^{-1} \mathrm{x}^{2 / 3} \\
\Gamma=\mathrm{g}\left(1 \mathrm{~m}_{\mathrm{o}} / \mathrm{m}\right)\left(\mathrm{T} / \mathrm{T}_{\mathrm{o}}\right) \mathrm{w}_{\mathrm{o}} \mathrm{r}_{\mathrm{o}}{ }^{2}+\mathrm{g} Q_{\mathrm{h}} /\left(\pi \mathrm{C}_{\mathrm{p}} \rho^{\mathrm{T}} \mathrm{T}\right)
\end{gathered}
$$

where $u$ is the mean wind speed, $x$ is the downwind distance, $g$ is the acceleration of gravity, $m$ is the mean ambient molecular weight, $m_{0}$ is the efflux molecular weight, $T$ is the ambient absolute temperature, $T_{0}$ is the efflux absolute temperature, $w_{n}$ is the mean efflux velocity, $r_{0}$ is the stack radius, $Q_{h}$ is the heat emission rate, and $C_{p}$ is the specific heat capacity of air $\left(0.24 \mathrm{cal} / \mathrm{gm}^{\circ}{ }^{\circ} \mathrm{K}\right)$. The quantity $\mathrm{g} /\left(\pi \mathrm{C}_{\mathrm{p}} \rho \mathrm{T}\right)$ is a constant, $3.7 \times 10^{-5}$ $\left(\mathrm{m}^{4} / \mathrm{cal}-\mathrm{sec}^{2}\right)$, times the ratio of standard sea level pressure to the ambient pressure.

The first term in equation (2) accounts for the plume rise due to initial effluent momentum, and the second term is the buoyancy contribution. The plume rise due to initial effluent momentum is neglected in the ASSM program for two reasons. First, the plume rise due to initial momentum is usually small compared to the buoyancy effect for most sources; second, and more important, the stack exit velocity data for most sources is unreliable unless a good stack sampling study has been performed. 
The heat emission rate is the only source emission data required to calculate the plume rise due to buoyancy. For combustion sources the stack heat emission rate is a fraction of the total produced in the combustion

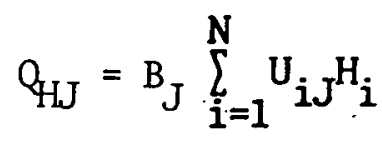

where $Q_{\mathrm{HJ}}$ is the stack heat emission rate for combustion source type $J, B_{J}$ is the fraction of the combustion heat lost to the stack from boiler type $\mathrm{J}$, $U_{i J}$ is the use of fuel $i$ by source $J$, and $H_{i}$ is the heat content of fuel $i$. Typical values of $B_{J}$ might be .1 for large steam-electric power plants and .2 for smaller space-heating units. Fuel use data on emission sources is available in the IPP inventory or from fuel suppliers, and therefore $Q_{H}$ for combustion sources can be readily calculated. 
C. Seasonal Variations

The primary use of the ASSM program is to calculate air quality levels for "episode-prone" meteorological conditions. Although episodes are usually caused by poor meteorology, variations in emission levels will usually determine the severity of the episode. Therefore seasonal emission data is required by ASSM in order to precalculate the episode potentials during different seasons. Some sources have operating schedules that do not correspond to any climatic season but operate on an economic schedule. These emission variations must also be included in the preplanning of episodes using ASSM. Both types of emission variations (climatic and economic) can be handled within the framework of the ASSM program. Changes in the source emission data can be made by modifying an entire class of sources (e.g., residential, commercial, and industrial space heating) or by modifying the emission pattern of an individual source (e.g., power plant). The Standard Industrial Classification (SIC) Is used as llee source elassification code. Modification of individual sources is performed using an input array of modification fartors: 
D. Space Heating

Residential and commercial (R/C) and industrial heating plants have seasonal variations in most areas of the country. Most residential and commercial emissions are aggregated into area sources in an emission inventory. This, of course, might exclude some large residential or commercial structures with large enough heating plants, and emissions, to be considered point sources. Fuel suppliers usually have data on the seasonal utilization of fuels by residential, commercial, and industrial sources for space heating.

Once the fraction of emissions that originate from space heating sources is determined, the next step is to determine the seasonal variation. If fuel suppliers do not have this data, space heating seasonal variations can be determined from the degree-day heating in a region. Degree-day heating is the number of degrees the average temperature on a given day is below the critical temperature. The critical temperature is defined as the temperature above which there is no heating, and below which there is heating. For example, if the average temperature for a day in March was $55^{\circ} \mathrm{F}$, and the critical temperature was $65^{\circ} \mathrm{F}$, then that day would have 10 degree-days of heating. This technique assumes a linear relationship between fuel use and ambient temperature; although not exact, the linear assumption represents a good approximation to the fuel use pattern unless temperatures are quite extreme.

Equation (4) shows the method used in calculating the seasonal variation in emissions from space heating. A critical temperature of $65^{\circ} \mathrm{F}$ is assumed. 


$$
\begin{aligned}
& F_{J}=\frac{S_{J}}{D_{J}}=\frac{\sum_{i=1}^{N_{J}} g_{i}}{D_{J}}, \text { where } g_{i}=\left\{\begin{array}{c}
65-T_{i} \text { for } T<65 \\
0 \text { for } T_{i} \geqslant 65
\end{array}\right. \\
& D_{J}=\left(\sum_{J=1}^{N} s_{J}\right) \frac{N_{J}}{365}
\end{aligned}
$$

where $F_{J}$ is the emission factor which when multiplied by the annual average emission rate gives the seasonal emission rate, $T_{i}$ is the average daily temperature, $\mathrm{S}_{\mathrm{J}}$ is the number of degree-days of heating occurring in season $J, N_{J}$ is the number of days in season $S_{J}, D_{J}$ is the annual average number of degree days that occur in a season $\mathrm{S}_{\mathrm{J}}$, and $\mathrm{N}$ is the number of seasons selected in the year. Seasons can be of any length, and the ASSM program is capable of handling four different seasons. Equations (4) and (5) need not be used for each day in the year but could be modified using average weekly or monthly temperatures. This depends entirely upon the seasonal temperature variations and the availability of data on the region. 


\section{E. Mixing Height}

Another seasonal variable is the mixing depth or lid height. The ASSM program uses seasonal mixing heights; if only one mixing height is used however, then it is assumed for all seasons. Since the vertical mixing depth is an important parameter for diffusion and since wide variations in mixing heights exist for different seasons, it is important to utilize this option. Seasonal mixing height data can be obtained from the local Environmental Meteorological Support Unit (EMSU) station or from a local airport that performs soundings. A regional meteorologist would probably have historical mixing heights already tabulated for the control region. The precalculation of the effects of a non-typical mixing height (inversion) can be performed by running a season with an assumed inversion lid height. 
F. Vertical Diffusion

In the process of developing the ASSM program from AQDM, individual meteorological conditions were run to determine the accuracy of the AQDM plume model in calculating individual uncalibrated conditions. Separate problems were run for a variety of wind speeds and stability classes. Since the low wind speed cases consistently produced very high pollutant levels, some of them were checked with the PUFF model, which has been validated with monitored air quality data. This check showed the AQDM model to be overcalculating by an order of magnitude for some of these very low wind speed cases.

A recent study performed by $D$. Rote ${ }^{5}$ suggests a possible reason for the overcalculation of the AQDM program. Kote shows that the steadystate plume formulation suffers from its $1 / u$ ( $u$ is wind velocity) dependence at low wind speeds when downwind-distance-dependent vertical diffusion coefficients are used in the steady-state formulation. Concentrations (X/Q) are proportional to $1 / \mathrm{u}$ and calculate unrealistically high concentrations even in the 4 to 6 -knot wind speed class used by AQDM. When the travel-timcdependent vertical diffusion coefficients are used, the high values calculated by the AQDM steady-state plume are reduced to realistic levels. As stated by Rote, even though the use of the travel-time-dependent coefficients has not been rigorously justified, their functional dependence upon $u$ is much more satisfactory than the downwind-distance-dependent coefficients at low wind speeds. Using the travel-time-dependent coefficients produces more realistic values down to a wind speed of $1 \mathrm{mph}$, and since the lowest wind speed classification in the ASSM program uses an average speed of about 1.5 knots, it seems reasonable to use the travel-time-dependent coefficients for all wind speed classes. Using the travel-time-dependent coefficients shows improvenents in 
the air quality calculations even in the 7-10 wind speed class for some cases. The trave1-time-dependent coefficients are those of D. B. Turner. ${ }^{6}$ A one-hour measuring time is assumed for the vertical diffusion coefficients. 
G. Horizontal Dispersion

ASSM uses uniform pollutant dispersion in the horizontal direction within a 22 1/2-degree angle centered in the downwind direction from the source. This assumes that the plume is entrained in a $22-1 / 2$-degree "channel" and spreads uniformly within the "channel" This assumption is reasonable for the steady state formulation used by ASSM and problems that include many sources. 


\section{ISOPLETH PLOTTING}

A. Isopleth Piotting System

One of the options available from the dispersion program is the creation of a data file containing the location and pollutant concentrations at specified receptors in a given region. Based upon this data file, an isopleth plotting system has been designed and implemented to display the air quality for that region.

The plotting system produces isopleths on both a line printer and $35 \mathrm{~mm}$ film. Figures C-4 and C-5 represent the isopleth displays on printer and film respectively for a sample case. Both outputs are produced from a version of the SYMAP (Synagraphic Computer Mapping Program*) system that has been extended to include film output. In the remainder of this section we will discuss the general characteristics of that extended SYMAP system. ${ }^{9}, 10$ Scc. B bclow considers the film-plotting portion of that system in greater detail.

The dispersion analysis system was designed to display the isopleths and geographic characteristics of a particular region on $35 \mathrm{~mm}$ film. In order to produce "smooth" isopleths, it is necessary to have pollutant concentrations for a fine regular grid system. However, the cost of computing the concentrations with the dispersion program for a suitable mesh is prohibitive. The obvious alternative is to interpolate from the course grid in the data file to a fine grid with values suitable for contouring. Since nongrid receptors are also included in the data file, the interpolation must include these data points when generating the regular grid.

The SYMAP program was selected because of its capability of accepting data on a nonregular grid and producing a fine mesh of regularly spaced data. 
Additionally, since SYMAP is a contouring package, its output was designed to produce smooth contours.

In the contour map displayed in Figure C-4, SYMAP assigned a value to each print position. These values were output to a scratch file ("Tape 8"), and subsequently input and contoured on $35 \mathrm{~mm}$ film, Figure C-5. For the sample problem described in Appendices B and C, SYMAP started with a nonregular receptor grid of 268 points (average mesh size is 7.5 kilometers) and produced a regular grid of approximately 9200 points (mesh size is 0.1 kilometer). 


\section{B. Film-Plotting Subsystem}

The isopleth plotting system described in Sec. A above produces isopleths and regional characteristics on $35 \mathrm{~mm}$ film. The device used is the IBM 2280 Film Recorder. The recording area on film is 1.17 inches by 1.17 inches and is divided into 4096 by 4096 points. The distance between adjacent horizontal or adjacent vertical points is called a raster unit (r.u.). Some of the features of the 2280 will be described here. For a more detailed description, consult Reference 11.

Images (characters and lines) are composed of vectors. When plotting vectors the beam is moved from its current position to the specified new position. The beam can either be blank (film not exposed) or unblank (film exposed). Characters may be plotted in two different sizes: basic and large. Figure C-5 contains both sizes for comparison: Characters must always be plotted parallel to the horizontal axis, and any standard IBM character can be plotted.

Since direct use of film orders requires assembly language, an interface package has been developed so that FORTRAN programs can more easily use the 2280. This film-plotting subroutine package (FSP) is an assembly language routine, callable from FORTRAN; utilizing user-supplied or default parameters, it converts the user's data into film orders and data usable by the IBM 2280 Film Recorder.

The actual contouring is done by a set of FORTRAN subroutines, namely, GRAPH, SECDRV, and DECIDE, * which access the FSP. The routines used by the isopleth plotting system for producing film output will be described in Sec. C below. For a more complete description, consult Reference 13. 
C. Film-Plotting Subroutine Package Routines

In this section we will describe the set of routines that are contained' in the Film-Plotting Subroutine Package for the IBM 2280 Film Recorder, 11,13 and are used in the isopleth plotting system.

1) FINIT Initializes FSP. - This routine sets the calling sequence type for FORTRAN programs. It must be the following:

\section{CALL FINIT $(1,2)$}

2) FDATM Define Input Argunent Mode - This routine sets the data mode to be floating point in units defined by the user's coordinate system. It must be the following:

CALL FDATM (2)

3) FLIND Set Line Density - This routine sets the film line density. It must he the following:

CALL FLIND (1) 
4) FLINW Set Line Width - This routine sets the film line width. It must be the following:

CALL FLTINW (1)

5) FXYLIM Define Data Mapping Units - This routine is called to set the maximum and minimum values of the user's coordinate system. It has the following form:

CALL FXYLIM (XMIN, YMIN, XMAX, YMAX) XMIN, YMIN define the minimal $x, y$ values in the user's coordinate system (lower lefthand corner of the plotting area). XMAX, YMAX define the maximal $x, y$ values in the user's coordinate system (upper right hand corner of the plotting area). The four values are in the same units as the receptor grid.

6) FCHSZ Set Character Size - This routine sets the character size of the characters to be generated. It has the following form:

CALL FCHSZ (I)

I is 2 for basic characters, that is, each character occupies $28 \times 28 \mathrm{r} . \mathrm{u}$., there are 74 characters per 1ine, and 52 lines per frame.

I is 3 for large characters, that is, each each character occupies 56 x $56 \mathrm{r} . \mathrm{u}$., there are 49 characters per line, and 35 lines per frame. 
7) FCHAR Plot a Single Character - This routine plots

a single character at a specified location.

It has the following form:

CALL FCHAR (CHAR, $X, Y$ )

The character specified by CHAR is plotted

at the point whose coordinates are $\mathrm{X}, \mathrm{Y}$.

8) FTEXT Plot a String of Characters - This routine

plots a string of characters either horizontally

or vertically. It has the following form:

CALL FTEXT (TEXT, ICNT, IOR, X, Y)

TEXT is an array containing the string of characters.

ICNT is the number of characters to be plotted.

IOR is 1 for horizontal text and 2 for vertical text.

$X, Y$ represent the conrdinates of the starting point of the first character in the string.

9) FLNSG . Draw a Line Segment - This routine draws a line segment between two specified points. It has the following form.

CALL FLNSG $(X 1, Y 1, X 2, Y 2)$ $X 1, Y 1$ specify one end point of the line to be drawn. X2, Y2 specify the other end point.

10) FERROR Interrogate Error Code - This routine obtains the value of the error code. It has the 
following form:

CALL FERROR (K)

$K$ is an integer representing the latest error code. If $\mathrm{K}$ is 0 no error has occurred. There are 16 additional values representing various errors. They are not listed here but can be found in Reference 13.

11) FADV Advance the Film - This routine advances the film for the start of the next frame. It must be of the following form:

CALL FADV (4)

After one complete plot has been made and before the start of plotting on the next frame, FADV must be called. The separation between frames is two inches.

This completes the description of the FSP routines used in the isopleth plotting system. It is important to remember that all coordinate references to the film plotting area must be in the same units are the receptor grid in the dispersion program.

Various examples of the use of these routines are found in the source listings of subroutines FLEXIN and GRAPH in Appendix C.. It would be advantageous to consult the sample isopleth plot in Figure $\mathrm{C}-5$ when considering the various FSP routines. 


\section{EPISODE CONTROL METHODOLOGY}

Stepwise procedures for pre-planning and using the episode control methodology are described in this chapter. Episode pre-planning refers to the effort required to collect and process data for an air quality region before the occurrence of an episode. 'This procedure involves:

1) An assessment of the meteorological and geographical characteristics of possible episodes in an air quality region;

2) Gathering of a complete data base containing source emission levels, operating characteristics, and geographical distribution;

3) The pre-calculation of pollution contours predicting the possible air quality levels expected in the event episode-prone meteorological conditions develop.

Pre-calculating information before the occurrence of episodes not only is useful for developing effective control strategies quickly but provides insight into the air pollution problems characteristic of a particular air quality region. For example, certain regions may have episode problems that are caused by basically uncontrollable sources such as residential space heating.

A procedure to develop an effective control plan must be technically sound so as to eliminate not only undercontrol strategies, but, and more importantly, over-control strategies. Pre-calculating data for a region is the first step toward creating a technically sound control strategy.

The second part of this chapter describes the procedure for developing an effective control plan using the pre-planned data technique. This procedure does not include any discussion of the controllability or uncontrollability of different sources, either for technical or political reasons. A sample region 
(Chicago) will be used in the stepwise procedure; it will be followed through development of the necessary data and creation of an effective full strategy for a hypothetical episode. Since every region has different air quality problems, the procedures will be general and will not directly follow the problems existing in Chicago. Of course the air quality problems characteristic of the Chicago Region will probably emerge from the analysis. 
A. Episode Control Data Base Development

A data base necessary for creating effective control strategies should be developed in the order occurring in this section. Each step in the development of a data base guides the preparation of the next set of data.

1. Source Emission Inventory

The starting point for the development of any air pollution control program is a complete source emission inventory. The effectiveness of the control program is determined to a large extent by the accuracy and the completeness of this inventory. Chapter II describes the lype anil format of inventory required for effective episode planning.

a. Establishment of Data Base

Inventory lists like those described in Chapter II should be prepared for the region. Computer programs can be used to order and print the lists of sources for large inventories. Fur sllldler inventuries, it may be more convenient to have typed lists. For the Chicago Region, which is in an arca of acute air quality problems, an emission inventory was prepared by the U.S. Environmental Protection Agency in the IPP inventory format. This inventory format was processed using computer programs listed in Appendix A, and a regional source file was created. Parts of this source file are shown in Chapter II. There are 459 large point sources and 169 area sources in the inventory. The Chicago Department of Environmental Control (the major local control agency) was then contacted to determine whether any changes had been made in these source emissions. This procedure should be followed in developing every inventory. That is, the data base should be updated using local information, either from local control agencies or from fuel suppliers or other groups who have data about emissions in the area. Included would be private, industria: 
organizations such as coal users. In the case of the Chicago inventory, several fuel conversions were discovered for large point sources. Therefore the regional source file was updated to reflect these changes. The computer programs used to print the regional lists are quite simple and could be combined into one program that just prints out a general regional file. In summary, the basic procedure here was (1) to find a good emission inventory (preferably in an IPP format), (2) to update this inventory with data from local control agencies, and (3) to develop a regional source file. Next, a cursory examination of the regional source file should be carried out to determine the nature of the problems in the region. A brief examination of the Chicago file indicates that the major sulfur dioxide emissions are from large, fossil-fueled electrical generating stations and the major particulate emitters are the primary metals industry located in the region. One way of identifying these large sources is by means of source location maps; such maps may in turn be useful in episode control planning. Figures 3 and 4 show source location maps (sulfur dioxide and suspended particulates) for the Chicago Metropolitan Air Quality Region. These source location maps show the relative location of large point sources within the jurisdictional boundaries of the region. Source location maps should be drawn on a large format (standard E-size drawing) and duplicated (ozalid) so that they can be used for strategy planning. A Universal Transverse Mercator (UTM) coordinate system should be used in the margins for planning purposes. The origin of the coordinate system is located at the lower left of Figs. 3 and 4 . Source numbers on the location maps should correspond to the numbers used in the regional source file, or supplementary source guides can be used to relate source lists to the location maps. This 


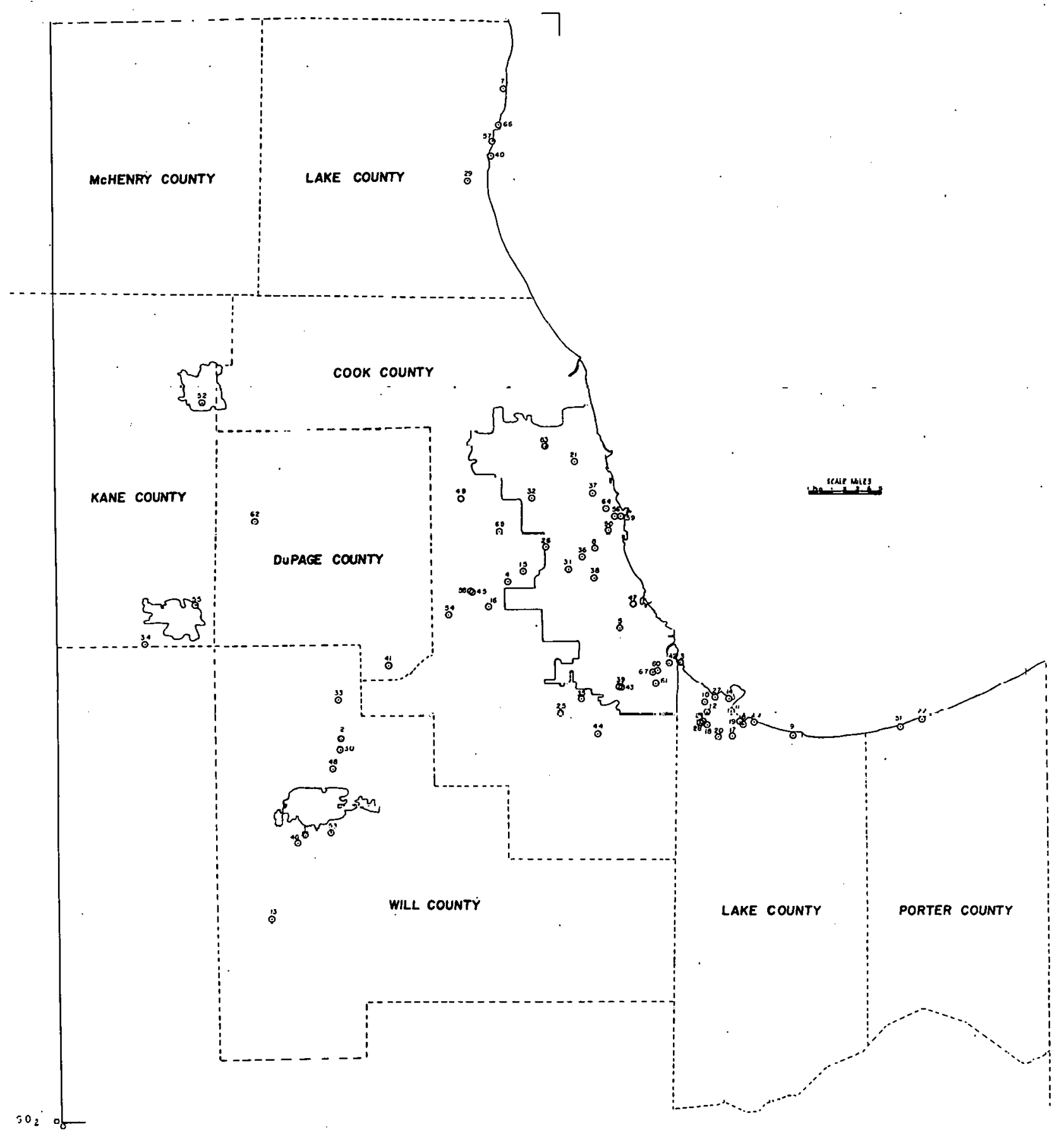

Fig. 3. Largest Sulfur Dioxide Point Sources in the Chicago Metropolitan Air Quality Control Region. ANL Neg. No. 190-30. 


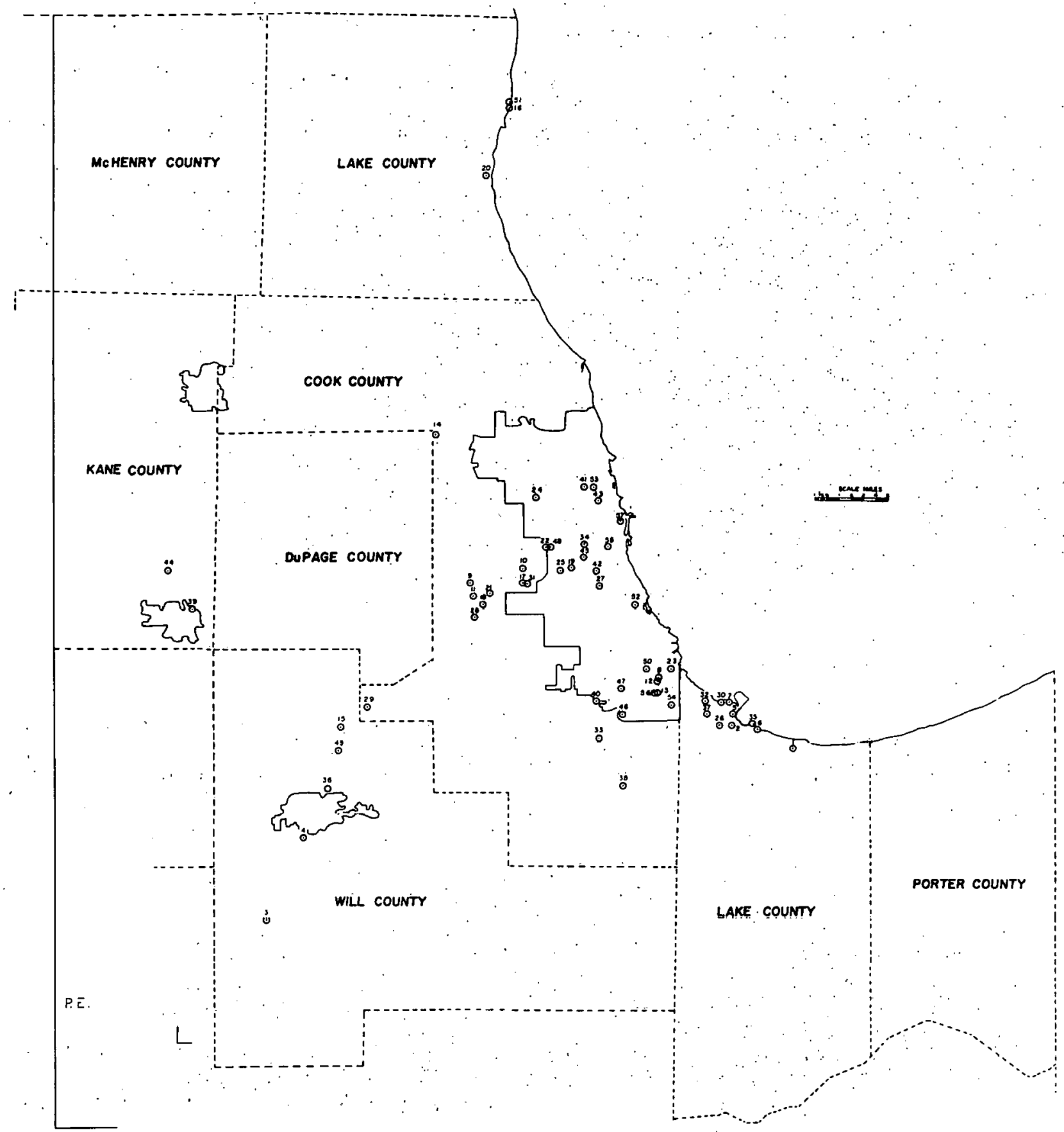

Fig. 4. Largest Suspended-particulate Point Sources in the Chicago Metropolitan Air Quality Control Region. ANL Neg. No. 190-31. 
latter technique is particularly useful for avoiding congestive maps when there are many sources in a small area. Tables IX and $X$ represent a supplementary source guide for the sources on this location map (Figs. 3 and 4). Source location maps should be made for every major pollutant, including hazardous materials. These maps can be easily prepared by tracing the jurisdictional boundaries and coordinate system from a large-scale (twodegree) U.S. Geological Survey Map. The local, regional land-use planner will also have maps that could be used.

Annther important part of the regional source file is information on the controllability of sources in the region. For one developing an episode control strategy it is essential to be able to determine which sources are controllable. Simple listings containing names and types of sources (e.g., combustion, process) is one method of categorizing source control. TABLE XI shows a listing of large controllable combustion sources in the Chicago Region, along with their fuel types. Table XII shows another controllable source list (for power plants in the Chicago Region). For each plant, in addition to its emission rate, the control benefit per unit cost is also listed (emission/MNe). If the file of the episode "action plans" is available for a region, then source control is well known at every stage of an episode. This is usually not the case, however; therefore information on controllability of controllable sources should be prepared separately. These lists can be generated either from information provided by a local dir pullutivi planing agency or by simply categorizing the sources by types and recognizing the operational constraints of each source type.

b. Regional Monitoring Network

Regional air quality data will always be important information in episode control strategy. Even the best air quality dispersion models do not 
TABLE IX. Sulfur Dioxide Emissions in the Chicago Region

\begin{tabular}{|c|c|c|c|c|c|c|}
\hline & Source Number & Source Name & $\begin{array}{l}\mathrm{SO}_{2} \\
\text { tons/day }\end{array}$ & $\begin{array}{l}\text { Polit. } \\
\text { Juris. }\end{array}$ & $\mathrm{X} \mathrm{mi}$ & $\mathrm{Y} \mathrm{mi}$ \\
\hline 1 & $15 b, 156,157$ & Commonwealth Edison Joliet $\mathrm{pP}$ & 831.00 & 1 & 20.5 & 24.0 \\
\hline 2 & 161,162 & Conmonwealth Edison Will Cty. PP & 466.51 & 1 & 23.4 & 33.6 \\
\hline 3 & 330 & Commonwealth Edison Stateline PP & 375.00 & 6 & 51.2 & 38.4 \\
\hline 4 & 159 & Commonwealth Edison Ridgeland PP & 308.00 & 1,2 & 38.0 & 45.2 \\
\hline 5 & 383 & Commonwealth Edison Crawford PP & 303.00 & 2 & 41.3 & 46.7 \\
\hline 6 & 332 & Commonwealth Edison Mitchell PP & 267.00 & 8 & 57.2 & 33.5 \\
\hline 7 & 160 & Conmonwealth Edison Waukegan PP & 258.00 & 1 & 37.8 & 85.1 \\
\hline 8 & 381,382 & Conmonwealth Edison Fisk PP & 206.50 & 2 & 44.8 & 48.3 \\
\hline 9 & 320,321 & U.S. Steel & 203.50 & 8 & 60.3 & 32.1 \\
\hline 10 & $\begin{array}{l}427,276,281 \\
428,424\end{array}$ & Amoco & 149.22 & 9 & 53.5 & 35.6 \\
\hline 11 & - & Inland Stee ${ }^{*}$ & 145.37 & 9 & 55.3 & 34.8 \\
\hline 12 & $\begin{array}{l}425,423,274, \\
280\end{array}$ & Atlantic & 97.78 & 9 & 53.5 & 34.1 \\
\hline 13 & $4,58,190$ & Joliet Army Ammunition Plant & 71.90 & 1 & 17.1 & 17.1 \\
\hline 14 & - & Youngstown Stee ${ }^{* *}$ & 59.61 & 9 & 55.0 & 35.2 \\
\hline 15 & 390 & Metropolitan Sanitary District & 47.00 & 2 & 38.8 & 46.2 \\
\hline 16 & 175 & Corn Products & 45.40 & 3 & 35.6 & 43.1 \\
\hline 17 & $\begin{array}{l}431,426,430 \\
275,282,279\end{array}$ & Cities Service & 42.98 & 9 & 55.9 & 32.3 \\
\hline 18 & $420,270,268$ & Union Carbide & 38.09 & 9 & 54.5 & 33.3 \\
\hline 19 & 432 & Universal $\wedge$ tlas Cement Mil1 6 & 36.50 & 8 & 56.6 & 33.4 \\
\hline 20 & 421 & Du Pont & 35.00 & 9 & 54.9 & 32.0 \\
\hline 21 & 380 & Commonwealth Edison Northwest PP & 28.95 & 2 & 42.7 & 54.4 \\
\hline 22 & 331 & $\begin{array}{l}\text { Northern Ind. Power Supply Co. } \\
\text { NIPSCO (Burns Harbor) }\end{array}$ & 28.50 & 6 & 71.8 & 33.6 \\
\hline 23 & 433 & U.S. Stee1 Atlas Harbor & 24.11 & 8 & 57.0 & 33.5 \\
\hline 24 & 269,419 & Stauffer Chemical Co. & 23.81 & 10 & 53.6 & 30.3 \\
\hline 25 & 194 & Clark Refinery & 21.36 & 1 & 41.9 & 34.8 \\
\hline 26 & 370,141 & Western Electric & 19.50 & 1,2 & 40.3 & 48.1 \\
\hline 27 & 271 & Union Carbide & 19.00 & 7 & 54.1 & 35.6 \\
\hline 28 & $429,277,273$ & Mobil Oil & 18.05 & 9 & 53.7 & 33.8 \\
\hline 29 & 164 & Great Lakes Training Centcr & 18.04 & 1 & 35.4 & 79.9 \\
\hline 30 & 197 & Texaco Refinery & 17.86 & 1 & 23.8 & 31.5 \\
\hline 31 & 371 & Campbell's & 11.25 & 2 & 42.9 & 46.8 \\
\hline 32 & 339 & Central Soya & 10.00 & 2 & 39.4 & 52.7 \\
\hline 33 & 196 & Pure Oil & 9.70 & 1 & 23.8 & 35.1 \\
\hline 34 & 193. & Armour-Dial Co. & 9.01 & 1 & 7.7 & 40.9 \\
\hline 35 & 8,187 & Chicago Copper \& Chemical & 8.86 & 1 & 43.7 & 35.2 \\
\hline 36 & 377 & International Harvester & 8.70 & 2 & 43.0 & 47.9 \\
\hline 37 & 347 & Proctor \& Gamble & 8.30 & 2 & 44.7 & 52.2 \\
\hline
\end{tabular}


TABLE IX (Contd.)

\begin{tabular}{|c|c|c|c|c|c|c|}
\hline & Source Number & Source Name & $\begin{array}{l}\mathrm{SO}_{2}, \\
\text { tons/day }\end{array}$ & $\begin{array}{l}\text { Polit. } \\
\text { Juris. }\end{array}$ & $\mathrm{X} \mathrm{mi}$ & $Y \mathrm{mi}$ \\
\hline 38 & 337,338 & Darling \& Co. & 8.12 & 2 & 44.2 & 45.8 \\
\hline 39 & 351 & Interlake & 7.30 & 2 & 46.0 & 34.1 \\
\hline 40 & 184 & Abbott Labs No. Chicago & 6.91 & 1 & 36.9 & 81.4 \\
\hline 41 & 150 & Argonne National Laboratory & 5.92 & 1 & 27.2 & 38.8 \\
\hline 42 & 350 & Marblehead Lime & 5.88 & 2 & 50.4 & 38.3 \\
\hline 43 & 348 & Sherwin-Williams & 5.80 & 2 & 46.9 & 36.6 \\
\hline 44 & 208 & Wyman-Gordon Co. & 5.77 & 1 & 44.1 & 32.8 \\
\hline 45 & 148 & G.M. Corp. La Grange & 5.60 & 5 & 34.5 & 44.4 \\
\hline 46 & 136 & Caterpillar & 5.56 & 1 & 19.5 & 23.7 \\
\hline 17 & $110^{\circ}$ & Tho Univorsity of Chicago & 5.38 & 2 & 17.7 & 13.8 \\
\hline 48 & 202,203 & GAF Corp. & 5.32 & 1 & 22.3 & 28.2 \\
\hline 49 & 135 & International Harvester & 5.28 & 1 & 33.0 & 52.5 \\
\hline 50 & 411 & University of Illinois & 5.00 & 2 & 45.2 & 49.9 \\
\hline 51 & 322 & Bethlehem Steel & 4.57 & 6 & 69.5 & 33.3 \\
\hline 52 & 169 & Elgin State Hospital & 4.56 & 1 & 12.3 & 60.4 \\
\hline 53 & 7 & American Cyanamid & 4.20 & 1 & 22.0 & 24.4 \\
\hline 54 & 142 & G.M. Fisher Body & 4.00 & 1 & 32.8 & 42.1 \\
\hline 55 & 177 & Aurora Paperboard & 3.99 & 1 & 11.7 & 43.3 \\
\hline 56 & 408 & Sears Roebuck \& Co. & 3.94 & 2 & 46.2 & 50.0 \\
\hline 57 & 132 & Ü.Ś. Steel & $3.8 \overline{5}$ & 1 & $\overline{3} 6.4$ & 82.4 \\
\hline 58 & 201 & McCook Standard Lime & 3.84 & 5 & 34.5 & 44.3 \\
\hline 59 & 375 & Container Corp. & 3.75 & 2 & 46.7 & 50.7 \\
\hline 60 & 352 & Interlake & 3.72 & 2 & 49.9 & 37.4 \\
\hline 61 & 353 & Republic Steel & 3.67 & 2 & 49.9 & 36.4 \\
\hline 62 & 183 & Americal Potash Corp. & 3.50 & 1 & 16.2 & 50.9 \\
\hline 63 & 386 & Mayfair Pumping Station & 3.44 & 2 & 40.2 & .56 .2 \\
\hline 64 & 376 & Container Corp. & 3.37 & 2 & 45.0 & 51.3 \\
\hline 65 & 385 & Central Park Pumping Station & 3.32 & 2 & 39.2 & 49.9 \\
\hline 66 & 34,206 & G.M. Corp. Chevrolet & .3 .26 & 1 & 37.6 & 83.9 \\
\hline 67 & 378 & Intermational Harvester & 3.03 & 2 & 49.7 & 37.8 \\
\hline
\end{tabular}

*Here Inland Steel is treated as an area source. Thirty (30) point sources are locatcd within a 1.44 square mile area, with center $(55.3,34.8)$, twenty-two (22) of which contribute to the total $\mathrm{SO}_{2}$ emission.

* *lere Youngstown Stee1 is treated as an area source. Eighteen (18) point sources are located with a 1.44 square mile area with center $(55.0,35.2)$, fourteen (14) of which contribute to the total $\mathrm{SO}_{2}$ emission. 
TABLE X. Particulate Emissions in the Chicago Region

\begin{tabular}{|c|c|c|c|c|c|c|}
\hline & Source Number & Source Name & $\begin{array}{l}\text { Part. } \\
\text { tons/day }\end{array}$ & $\begin{array}{l}\text { Polit. } \\
\text { Juris. }\end{array}$ & $\mathrm{X} \mathrm{mi}$ & $\mathrm{Y} \mathrm{mi}$ \\
\hline 1 & - & U.S. Steel* & 204.67 & 8 & 60.9 & 31.9 \\
\hline 2 & 432 & Univ. Atlas Cement Mill G & 102.00 & 8 & 56.6 & 33.4 \\
\hline 3 & $190,58,3,4$ & Joliet Army Ammunition Plant & 83.60 & 1 & 17.1 & 17.1 \\
\hline 4 & $155,156,157$ & Conmonwealth Edison Joliet PP & 58.80 & 1 & 20.5 & 24.0 \\
\hline 5 & - & Inland Steel** & 50.81 & 9 & 55.3 & 34.8 \\
\hline 6 & 433 & U.S. Stee1 & 50.20 & 8 & 57.0 & 33.5 \\
\hline 7 & - & Youngstown Stee ${ }^{\dagger}$ & 39.12 & 9 & 55.0 & 35.2 \\
\hline 8 & $\begin{array}{l}112,113,110, \\
111\end{array}$ & Wisconsin Steel & 33.37 & 2 & 49.6 & 37.6 \\
\hline 9 & 97 & McCook Material Service & 30.00 & 5 & 34.6 & 45.0 \\
\hline 10 & 390 & Metropolitan Sanitary District & 29.00 & 2 & 38.8 & 46.2 \\
\hline 11 & 29 & McCook Standard Lime & 26.29 & 5 & 34.5 & 44.3 \\
\hline 12 & $\begin{array}{l}352,98,99 \\
100,101\end{array}$ & Interlake & 24.15 & 2 & 49.9 & 37.4 \\
\hline 13 & $\begin{array}{l}353,105,104 \\
103,102\end{array}$ & Republic Steel & 23.28 & 2 & 49.9 & 36.4 \\
\hline 14 & $415,416,414$ & O'Hare Airport & 20.51 & 2 & 31.8 & 57.4 \\
\hline 15 & 161,162 & Commonwealth Edison Will County PP & 18.77 & 1 & 23.4 & 33.6 \\
\hline 16 & 160 & Commonwealth Edison Waukegan PP & 16.93 & 1 & 37.8 & 85.1 \\
\hline 17 & 159 & Commonwealth Edison Ridgeland PP & 16.50 & 1 & 38.0 & 45.2 \\
\hline 18 & 1,175 & Corn Products & 15.87 & 3 & 35.7 & 43.0 \\
\hline 19 & 371,71 & Campbel1's & 14.70 & 2 & 42.9 & 46.8 \\
\hline 20 & 164 & Great Lakes Training Center & 12.58 & 1 & 35.4 & 79.9 \\
\hline 21 & 49 & Mclook Reynolds Metals & 12.10 & 5 & 35.1 & 44.8 \\
\hline 22 & 370 & Western Electric Co. & 11.62 & 2 & 40.4 & 48.2 \\
\hline 23 & 95,350 & Marblehead Lime Co. & 11.24 & 2 & 50.4 & 38.3 \\
\hline 24 & 339,70 & Central Soya & 11.23 & 2 & 39.4 & 52.7 \\
\hline 25 & 383 & Commonwealth Edison Crawford PP & 11.21 & 2 & 41.3 & 46.7 \\
\hline 26 & $420,270,268$ & Union Carbide & 9.59 & 9 & 54.4 & 33.3 \\
\hline 27 & 337,338 & Darling \& Co. & 8.50 & 2 & 44.2 & 45.8 \\
\hline 28 & 26 & Vulcan Materials & 8.07 & 1 & 34.5 & 42.9 \\
\hline 29 & 51 & Lellont Mfg, & 6.71 & 1 & 25.0 & 35.6 \\
\hline 30 & 422,271 & Union Carbide & 6.47 & 7 & 54.1 & 35.6 \\
\hline 31 & 57 & Metropolitan Sanitary Dist. & 6.40 & 1 & 38.7 & 45.7 \\
\hline 32 & $\begin{array}{l}276,281,427 \\
424\end{array}$ & Amoco & 6.02 & 9 & 53.9 & 35.3 \\
\hline 33 & 208 & Wyman-Gordon Co. & 5.85 & 1 & 44.1 & 32.8 \\
\hline 34 & 381,382 & Commonwealth Edison Fisk PP & 5.69 & 2 & 44.8 & 48.3 \\
\hline 35 & 332 & Commonwealth Edison Mitcliell PP & 5.10 & 8 & 57.2 & 33.5 \\
\hline 36 & $\begin{array}{l}23,22,31 \\
202,203\end{array}$ & GAF Corp. & 5.07 & 1 & 22.4 & 28.2 \\
\hline
\end{tabular}


TABLE X (Contd.)

\begin{tabular}{|c|c|c|c|c|c|c|}
\hline & Source Number & Source Name & $\begin{array}{l}\text { Part. } \\
\text { tons/day }\end{array}$ & $\begin{array}{l}\text { Polit. } \\
\text { Juris. }\end{array}$ & $\mathrm{X} \mathrm{mi}$ & Y mi \\
\hline 37 & $\begin{array}{l}425,423,274 \\
280\end{array}$ & Atlantic & 4.83 & 9 & 53.5 & 34.1 \\
\hline 38 & 28 & Marblehead Lime & 4.79 & 1 & 46.6 & 28.5 \\
\hline 39 & 177 & Aurora Paperboard . & 4.70 & 1 & 11.7 & 43.3 \\
\hline 40 & 69 & Cargil1 & 4.25 & 2 & 49.4 & 35.8 \\
\hline 41 & 372 & Glidden Co. & 4.00 & 2 & 43.3 & 53.5 \\
\hline 42 & 125 & Sw. Mhm. Inc. & 3.74 & 2 & 44.5 & 46.3 \\
\hline 43 & 347 & Proctor \& Gamble & 3.64 & 2 & 44.7 & 52.2 \\
\hline 44 & 2 & Forty-eight Insulations & 3.55 & 1 & 9.9 & 46.3 \\
\hline 45 & 377 & İntemationai İlarvestcr & 3.39 & 2 & 43.0 & 47.9 \\
\hline 46 & 351 & Interlake & 3.33 & 2 & 46.0 & 34.1 \\
\hline 47 & 348,89 & Sherwin-Williams & 3.33 & 2 & 46.9 & 36.6 \\
\hline 48 & 141,53 & Western Electric Co. & 3.09 & 1 & 40.3 & 48.1 \\
\hline 49 & 197,11 & Texaco Refinery & 3.01 & 1 & 23.8 & 31.5 \\
\hline 50 & 126 & Calumet M. Inc. & 2.76 & 2 & 48.0 & 38.3 \\
\hline 51 & 200,27 & Johns-Manville & .2 .64 & 1 & 37.4 & 85.4 \\
\hline 52 & 411 & The University of Chicago & 2.55 & 2 & 47.7 & 43.8 \\
\hline 53 & 124 & Medillm. Inc. & 2.52 & 2 & 44.1 & 53.0 \\
\hline 54 & 93,343 & Bird \& Sons & 2.22 & 2 & 50.0 & 35.3 \\
\hline 55 & 341 & Joanna Western & 2.16 & 2 & 45.3 & 48.3 \\
\hline 56 & 61 & Continental Elevator $B$ & 2.15 & 2 & 49.4 & 36.4 \\
\hline 57 & 375 & Container Corp. & 2.03 & 2 & 46.7 & 50.7 \\
\hline
\end{tabular}

*Here U.S. Steel is treated as an area source. Six (6) point sources are located within a 1.44 square mile area with center $(60.9,31.9)$.

**Here Inland Steel is treated as an area source. Thirty (30) point sources are located within a 1.44 square mile area with center $(55.3,34.8)$, twenty-four (24) of which contribute to the total particulate emissions.

there Youngstown Steel is treated as an area source. Eighteen (18) point sources are located within a 1.44 square mile area with center $(55.0,35.2)$, seventeen (17) of which contribute to the total particulate emission. 
TABLE XI. Controllable Industrial P1ants with Large Sulfur Dioxide Emissions

\begin{tabular}{cll}
\hline Source No: & \multicolumn{1}{c}{ Name } & \multicolumn{1}{c}{ Fuel Types } \\
\hline 165 & Great Lakes Training Center & Coal, Oil \\
294 & Inland Steel Open Hearth* & Coal, Oil, Gas \\
269 & Union Carbide & Coal, Oil \\
281 & Atlantic Boilers & Oil, Gas \\
282 & Amoco Whit Boilers & Oil, Gas \\
283 & Cities Service Boilers & Oil, Gas \\
290 & Inland Steel Power Gen. 401 & Coal, Gas \\
321 & U.S. Steel Oil Combustion. & Oil, Gas \\
392 & Metropolitan Sanitary District & Coal, Oil \\
278 & Mobil Oil Ref. Boilers & Oil, Gas \\
323 & Bethlehem Steel Boilers & Oil, Gas \\
338 & Darling \& Co. & Coal, Oil \\
353 & Interlake & Coal, Oil \\
\hline
\end{tabular}

*Here Inland Steel has seven (7) plants with dual fuel capability and located within a 1 square mile area. 
TABLE XII. Commonwealth Edison (Power) Plants in the Chicago Region

\begin{tabular}{lrcccl}
\hline \multicolumn{1}{c}{ Plant } & MWe & $\begin{array}{c}\mathrm{SO}^{2}, \\
\text { tons/day }\end{array}$ & $\begin{array}{c}\text { Part., } \\
\text { tons/day }\end{array}$ & $\begin{array}{c}\mathrm{SO}^{2 /} \\
\text { MWe }\end{array}$ & $\begin{array}{c}\text { Part./ } \\
\text { MWe }\end{array}$ \\
\hline Joliet (new) & 1242 & 570 & 18.5 & 0.458 & 0.0149 \\
Stateline (total) & 944 & 375 & 1.14 & 0.37 & 0.0121 \\
Will Cty. No. 2 & 844 & 316.5 & 12.32 & 0.375 & 0.0146 \\
Crawford & 675 & 303.3 & 11.21 & 0.455 & 0.0168 \\
Waukegan & 1047 & 258 & 16.93 & 0.246 & 0.162 \\
Joliet-Old-1 & 117 & 171.5 & 1.30 & 1.465 & 0.11 \\
Will Cty. No. 1 & 328 & 150 & 6.45 & 0.457 & 0.196 \\
Fisk (new) & 341 & 116.7 & 3.89 & 0.34 & 0.114 \\
Fisk (old) & 168 & 89.8 & 1.8 & 0.534 & 0.17 \\
Joliet-Old-2 & 344 & 89.5 & 39.0 & 0.259 & 0.113 \\
Ridgeland & 647 & 84 & 1.88 & 0.130 & 0.0029 \\
Calumet & 121 & 22.22 & 1.97 & 0.184 & 0.0163 \\
Total & & 2171.52 & 115.25 & & \\
\hline
\end{tabular}


calculate air quality with the level of accuracy needed to control an episode. Therefore, it is important that episode control strategists know exactly what type of air quality is being monitored, where it is being monitored, and who can supply the data.

The first step is to survey all federal and local control agencies to determine what monitoring stations are operated in the region. Table XIII lists the sites that have $\mathrm{SO}_{2}$ monitoring stations in the Chicago Region. The tables should show the types of monitors available at each site (Table XIV).

The next step is to prepare a monitor location map to show the relative location of air quality sampling stations within the region. Figure V-3 shows air quality monitoring stations for $\mathrm{SO}_{2}$ in the Chicago Region. This map is similar to the source location map and could have been combined with it if the merged map would not have been overcongested. Accompanying the monitor location map should be a table that lists the stations and the air quality monitoring instruments available at the different locations. A typical (imaginary) tabulated list is shown by Table XIV for some of the monitoring stations in the Chicago Region that are located in Fig. 5. Since there are a large variety of monitoring instruments used, the accuracy and sampling times of these instruments vary quite widely. A checklist is also included in Table XIV to indicate the types of instruments available and therefore the types of data that could be obtained from the monitoring network. An instrument key is used to simplify the checklist (Table XV).

c. Regional Meteorological Data

Local meteorological data can usually be obtained either from the local weather station or from a regional meteorologist. Chicago data was obtained from a climatological study performed by H. Moses.14 Seasonal lid heights and temperatures for Chicago are shown in Table XVI. The average daily temperatures were also obtained for the Chicago Region for purposes of calculating seasonal 
TABLE XIII. Sulfur Dioxide Monitoring Stations in the Chicago Region

\begin{tabular}{|c|c|c|c|c|}
\hline & Station & $\mathrm{X} \mathrm{mi}$ & & $Y \mathrm{mi}$ \\
\hline 1. & Chicago No. 1 & 37.70 & & 57.20 \\
\hline 2. & Chicago No. 2 & 44.00 & & 55.20 \\
\hline 3 . & Chicago No. 3 & 37.90 & & 53.85 \\
\hline 4. & Chicago No. 4 & 45.40 & & 51.70 \\
\hline 5 . & Chicago No. 6 & 45.90 & & 49.45 \\
\hline 6. & Chicago No. 7 & 43.10 & & 49.75 \\
\hline 7. & Chicago No. 8 & 39.00 & & 50.40 \\
\hline 8 . & Chicago No. 9 & 46.20 & & 46.85 \\
\hline & Chicago No. 10 & 42.30 & & 45.65 \\
\hline 10. & Chiçago No. 11 & 43.55 & & 43.15 \\
\hline 11. & Chicago No. 12 & 47.80 & & 43.10 \\
\hline 12. & Chicago No. 13 & 40.30 & & 40.85 \\
\hline 13. & Chicago No, 14 & 44.55 & & 40.65 \\
\hline & Chicago No. 15 & 48.47 & & 40.14 \\
\hline 15. & Chicago No. 16 & 45.20 & & 37.00 \\
\hline 16. & Chicago No. 17 & 47.00 & & 34.40 \\
\hline 17. & Chicago No. 18 & 49.80 & & 34.35 \\
\hline 18. & Chicago No. 20 & 44.00 & & 58.30 \\
\hline 19. & Cälly Station & 16.00 & & 49.70 \\
\hline 20 . & Bedford Park No. 1 & 39.00 & & 42.80 \\
\hline 21. & Bedford Park No. 2 & 39.00 & & 42.50 \\
\hline 22. & Cook County No. 3 & 42.30 & & 64.30 \\
\hline 23. & Cook County No. 6 & 31.75 & & 50.00 \\
\hline 24. & Cook County No. 7 & 39.70 & 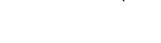 & 48.95 \\
\hline 25 . & Cook County No. 8 & 36.75 & & 42.80 \\
\hline 26. & Cook County No. 12 & 44.40 & & 31.70 \\
\hline 27 . & Cook County No. 13 & 50.00 & & 31.50 \\
\hline 28. & Conk Conunty No. 1.5 & 44.55 & $\cdot$ & 24.75 \\
\hline 29. & Elgin & 13.00 & & 62.50 \\
\hline 30 . & Whoaton & 2.1 .4 .5 & & 49.25 \\
\hline 31. & North Chicago & 35.50 & & 80.80 \\
\hline 32. & Waukegan & 35.75 & & 83.25 \\
\hline 33 . & Chicago Heights & 45.85 & & 25.25 \\
\hline 34. & Gary: No. 1 Fire Station & 60.70 & & 30.50 \\
\hline 35 . & Gary: $\cdot \Lambda$ irport & 56.90 & & 31.80 \\
\hline 36 . & Gary: Kuny School & 61.40 & & 25.30 \\
\hline 37. & Lake County: Taft School & 59.30 & & 17.70 \\
\hline 38 . & Whiting: So. Side School & 52.95 & & 35.25 \\
\hline 39 . & Hammond: City Hall & 51.85 & & 30.90 \\
\hline 40 . & E. Chicago: Fire Station & 54.10 & & 33.20 \\
\hline 41. & E. Chicago: Roxanna School & 54.60 & & 31.30 \\
\hline 42 . & E. Chicago: NASN & 56.50 & & 33.20 \\
\hline 43. & Porter County: So. Haven & 75.70 & & 18.40 \\
\hline 44. & Porter County: Ogden Dunes & 68.00 & & 32.90 \\
\hline 45. & Porter County: Chesterton & 75.20 & & 32.20 \\
\hline 46. & Porter County: Flint Lake & 75.60 & & 24.60 \\
\hline
\end{tabular}


TABLE XIV. Typical List of Monitoring Stations and Their Instruments (Chicago Metropolitan Air Quality Control Region)

\begin{tabular}{|c|c|c|c|c|c|c|c|c|}
\hline Station & WS & WD & $\mathrm{SO}_{2}$ & Part. & $\mathrm{CO}$ & $\mathrm{HC}$ & $\mathrm{NO}_{2}$ & $\mathrm{O}_{3}$ \\
\hline Chicago No. 1 & $X$ & $X$ & 01 & 12 & & & & \\
\hline Chicago No. 7 & $\mathrm{X}$ & $\mathrm{X}$ & 04 & 12 & & & & \\
\hline Camp Station & $\mathrm{X}$ & $X$ & 01 & 11 & 22 & 31 & 41 & 51 \\
\hline Bedford Park No. 1 & $\mathrm{X}$ & $\mathrm{X}$ & 02 & 12 & & & & \\
\hline Elgin & & & .01 & 12 & & & & \\
\hline Wheaton & & & 01 & 12 & & & & \\
\hline Gary Airport & $\mathrm{X}$ & $X$ & 01 & 12 & & & & \\
\hline Cook County No. 3 & & & 01 & 12 & & & & \\
\hline I11. EPA No. 1 & $x$ & $x$ & 01 & 11 & 22 & 32 & 42 & 51 \\
\hline
\end{tabular}




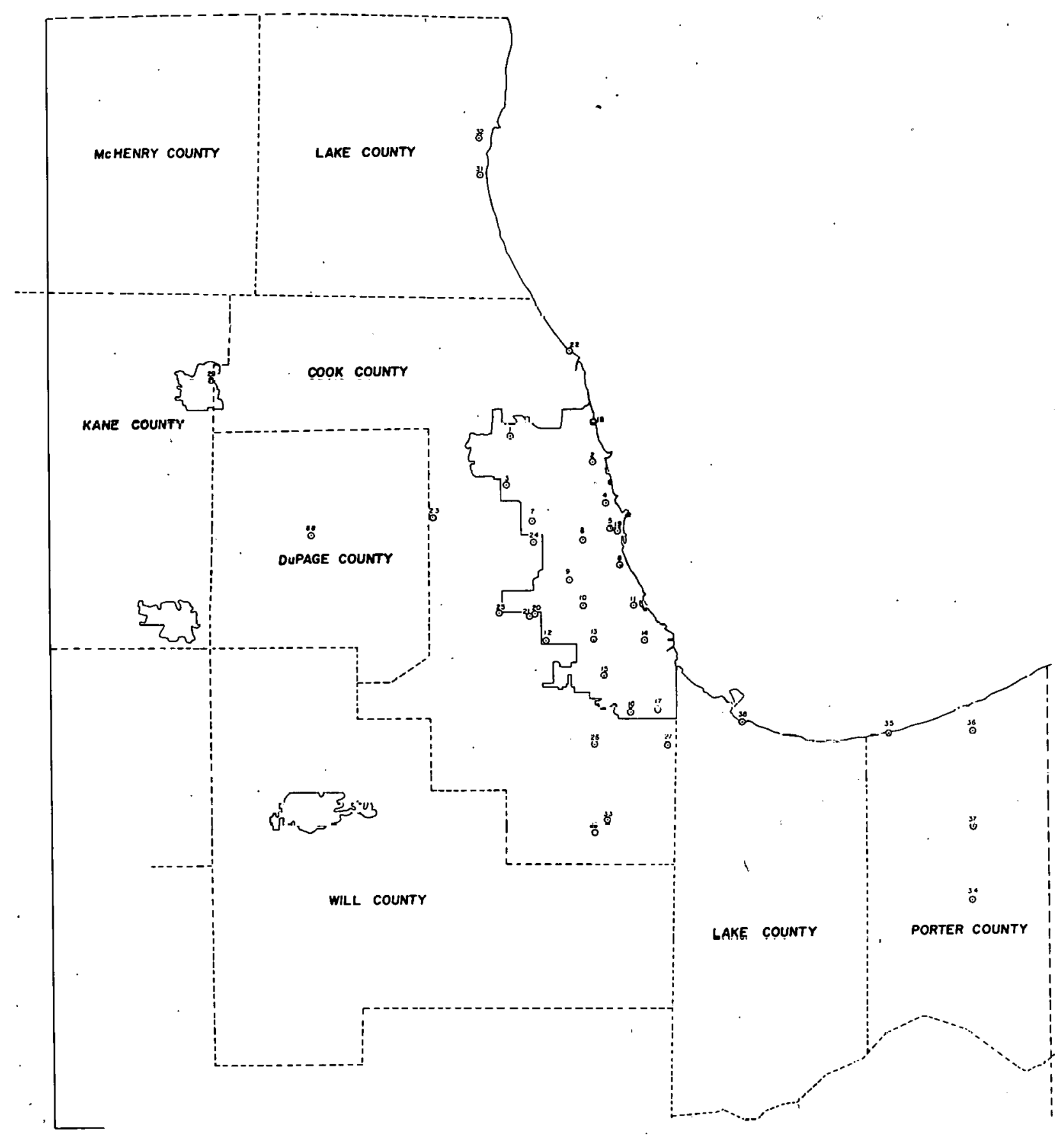

Fig. 5. Sulfur Dioxide Monitoring Sites in the Chicago Metropoli$\tan$ Air Quality Control Region. ANL Neg. No. 190-33. 
TABLE XV. Sampling-method Key for Monitoring Stations

\begin{tabular}{llll}
\hline Sulfur_Dioxide & Hydrocarbons & \\
01 & Bubbler & 31 & Total Hydrocarbon Analyzer \\
02 & Titrimetric & 32 & Gas Chromatography \\
03 & Flame Photometric & & \\
04 & Turbidimetric $\left(\mathrm{PbO}_{2}\right.$ candle $)$ & \multicolumn{2}{l}{ Nitrogen Dioxide } \\
05 & Turbidimetric $\left(\mathrm{K}_{2} \mathrm{CO}_{3}\right.$ alkaline plate $)$ & 41 & Bubbler \\
& & 42 & Electrochemical \\
Suspended Particulates & 43 & Chemiluminescent \\
11 & Tape Sampler & & \\
12 & Hi Volume Sampler & Oxidant \& Ozone \\
13 & Crystal Sampler & 51 & Bubbler \\
14 & Beta Gauge & 52 & Amperometric \\
& & 53 & Potentiometric \\
Carbon Monoxide & 54 & Chemiluminescent \\
21 & Gas Chromatography & 55 & UV Absorption \\
22 & Nori-Dispersive Infrared & & \\
\hline
\end{tabular}

TABLE XVI. Average Chicago Seasonal Mixing Heights and Temperatures

\begin{tabular}{lcc}
\hline & $\begin{array}{c}\text { Mixing Height } \\
\text { (meters) }\end{array}$ & $\begin{array}{c}\text { Temperature } \\
\left({ }^{\circ} \mathrm{F}\right)\end{array}$ \\
\hline $\begin{array}{l}\text { Dec-Feb } \\
\text { (Winter) }\end{array}$ & 600 & 30 \\
$\begin{array}{l}\text { Mar-May } \\
\text { (Spring) }\end{array}$ & 850 & 50 \\
$\begin{array}{l}\text { Jun-Aug } \\
\text { (Summer) }\end{array}$ & 1100 & 75 \\
$\begin{array}{l}\text { Sept-Nov } \\
\text { (Fal1) }\end{array}$ & 850 & 50 \\
\hline
\end{tabular}


heating emissions. One method of finding out about local meteorology is to talk to the local meteorologist, who is familiar with the area. Another method is to obtain weather tapes from the National Weather Center for the region and use the PERSIST code to determine the relative persistence of weather conditions. PERSIST was used for Chicago, and the result showed:

1) Chicago winds are mostly from the west,

2) Summer winds are usually southwest,

3) Winter winds are generally northwest and westerly,

4) Easterly winds usually do not porsist for any length of time:

\section{d. Precalculated Pollution Contours}

A major portion of the effort to preplan episode control is devoted to the calculation of pollution contours for episode-prone meteorological situations. The steady-state diffusion model described in Chapter III and Appendix $\mathrm{D}$ is used to calculate these contours. However, much of the input required by the ASSM program must be determined by the user. The most probable meteorological and source operating conditions must be examined to determine their episode potential. The question that must be asked is: "What meteorological conditions (1id heights, wind speeds, wind directions, stability conditions) could exist in that area?" It is of course possible to calculate pollution contours for every conceivable set of meteorological conditions. This would be expensive and cumbersome. Instead, the local meteorological conditions should be parameterized and grouped so that pollution contours can be calculated for a characteristic set of conditions. 'The following seasonal patterns characterize a region and must be supplied as input for using the steadystate diffusion algorithm in calculating pollution contours.

1) Seasonal mixing height,

2) Wind speeds,

3) Wind directions, 
4) Stability conditions,

5) Seasonal temperatures.

Source emission characteristics depend upon the types of sources that exist in a region, and therefore must be identified before contours can be developed. Space heating, which is dependent upon temperature, is only one type of emission source that is seasonally dependent. Some process industries operate on an economic season that is dependent upon the meteorological season (e.g., asphalt plants, power plants). The region has sources that have an operating schedule with seasonal dependence and must be identified so that the seasonal pollution contours can include emission variations. Most of these seasonally operating sources will be combustion sources that are tied to the seasonal temperature variations.

Space heating is one source that will almost always be seasonally dependent. The degree-day heating method described in Chapter III was used for Chicago; seasonal degree-day factors are listed below:

$\begin{array}{lc}\text { Winter } & 2.16 \\ \text { Spring } & 1.0 \\ \text { Summer } & .04 \\ \text { Fall } & .8\end{array}$

It was assumed that $60 \%$ of the emissions from area sources were due to seasonal space heating, and therefore would use seasonal degree-day factors for determining their seasonal source emissions. The other two major types of sources in the Chicago area, power plants and primary metals industries, do not have any climatological seasonal operating patterns. There is no significant seasonal variation in the load of power plants because the Chicago Region has. both an air conditioning and an electrical heating load. Primary metals industries, of course, do not have any climatological seasonal operational pattern; 
therefore, no seasonal emission variation would be assumed for 'any large point sources in the Chicago Region.

After establishing the seasonal emission variations, episode-prone meteorological conditions (MET SETS) must be identified so that pollution contours can be calculated. Many of these MET SETS are unlikely to occur and others would not create episode problems. Therefore, pollution contour calculations should be 1 imited to those MET SETS that could cause an episode and those conditions that are possible. For the Chicago Region, only the lower three wind speed classes ( 0 to 3,4 to 6,7 to 10 knots) in the ASSM program were considered episode-prone. The other higher wind speed classes were considered to have too much horizontal ventilation to cause episode problems. Eight wind directions (N, S, W, E, NW, NE, SW, SE) were considered adequate to identify episode problems in the Chicago Region and three stability classes (slightly unstable, neutral, unstable) were considered episodeprone situations. Three seasons were used for the Chicago Region: winter, summer, and spring. Since spring and fall have about the same mixing depth and have similar temperatures, there would be relatively little difference in their emissions. 


\section{B. Episode Control Strategy Development}

The first part of this chapter describes a preplanning procedure for episode control. This involves the development of a data bank of information that can be used to prepare control strategies during episodes. The remaining part of the chapter is concerned with the use of this data base for developing episode control strategies. A stepwise procedure will be given for a sample episode in the Chicago Region; the procedure illustrates the development of a control strategy using the precalculated data base. 1. Define Episode Potential

Conditions of the episode problem should be determined exactly before an episode control strategy is developed. The expected episode length and local wind direction should be known, along with local air quality levels.

For purposes of illustration an episode will be assumed in the Chicago Region. It is winter, a weak high pressure air mass has settled over the Chicago Region, and an air stagnation advisory has been issued for the area. The Whiting monitoring station reports $.45 \mathrm{ppm} \mathrm{SO}_{2}$ for the past 24 hours. Furthermore, the weak high pressure system is expected to remain in the area.... 2. Examine Pollution Contours for the Particular Mctcorological Conditions

The next step is to locate the pollution contours for the "met-set" that most closely fits the conditions existing in the area. Then, with the aid of the corresponding culpability lists, determine those sources contributing most to the asute air quality problems.

For the example case, the wind is assumed to be out of the southwest at around $2 \mathrm{mph}$. The $\mathrm{SO}_{2}$ pollution contour for the Chicago Region for the winter $(\mathrm{H})$, with neutral stability (NT), and a wind from the southwest (SW) at $0-3$ knots (3) is shown in Fig. 6. The problem areas are shown to be around the near north side of Chicago and northern Lake County, Indiana. The highest receptor shown in the culpability list (Table XVII) is very close to the Whiting 


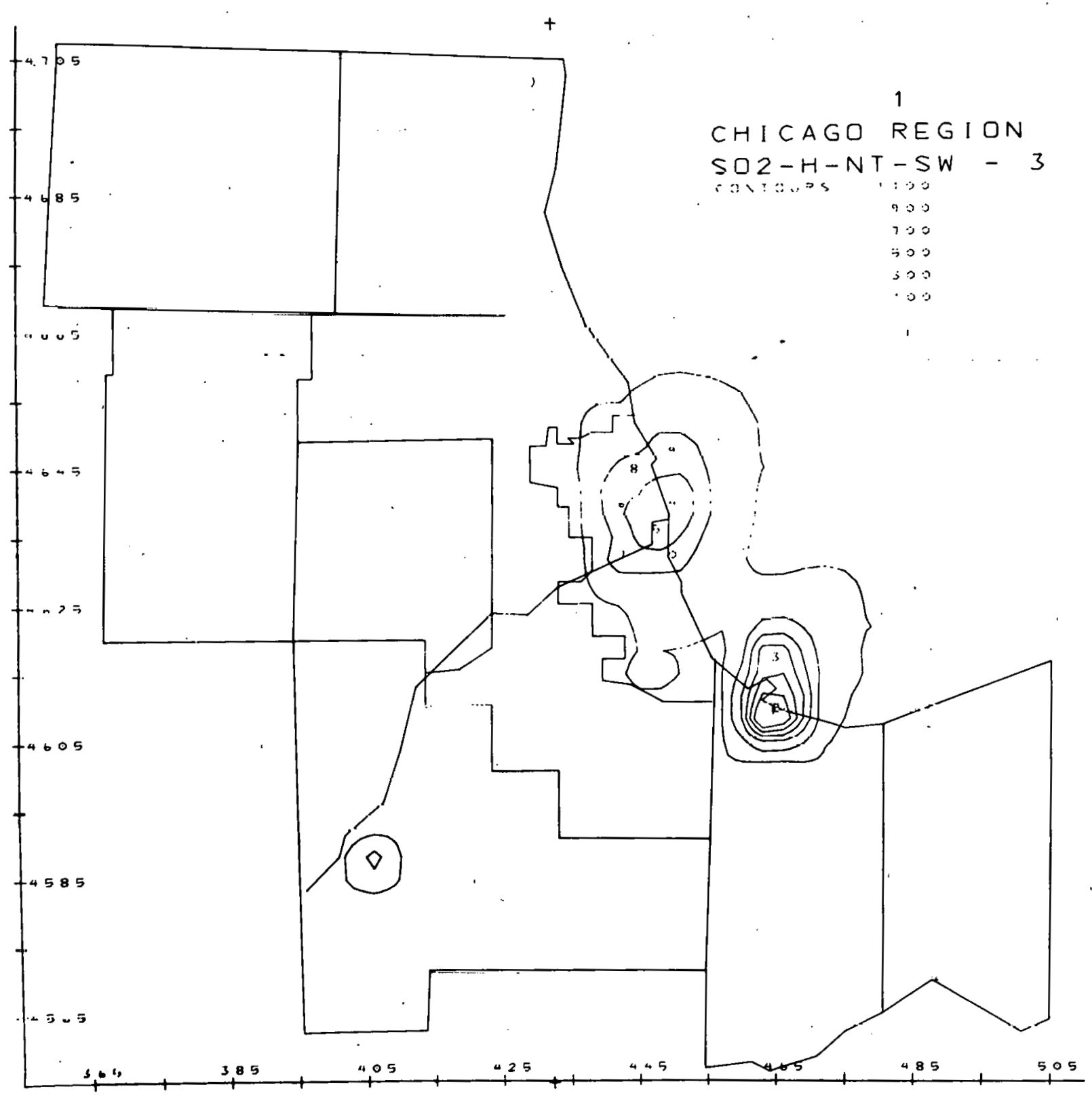

Fig. 6. Pollution Contours for the Chicago Region Sample Episode 
TABLE XVII. Culpability List

CHICAGO REGICN SOZ-H-NT-SW- 21

EHICAGO METROPOLI IAN AIR QUALITY CCNTRGL REGICN

SEASON DEC-FES STABILITY CLASS 4 WIND DIRECTION SW WINO SPEED O - 3 KAOTS

SO2 FOR HIGHEST RECEPTORS, (MICROGRAMS PER CUBIC METER )

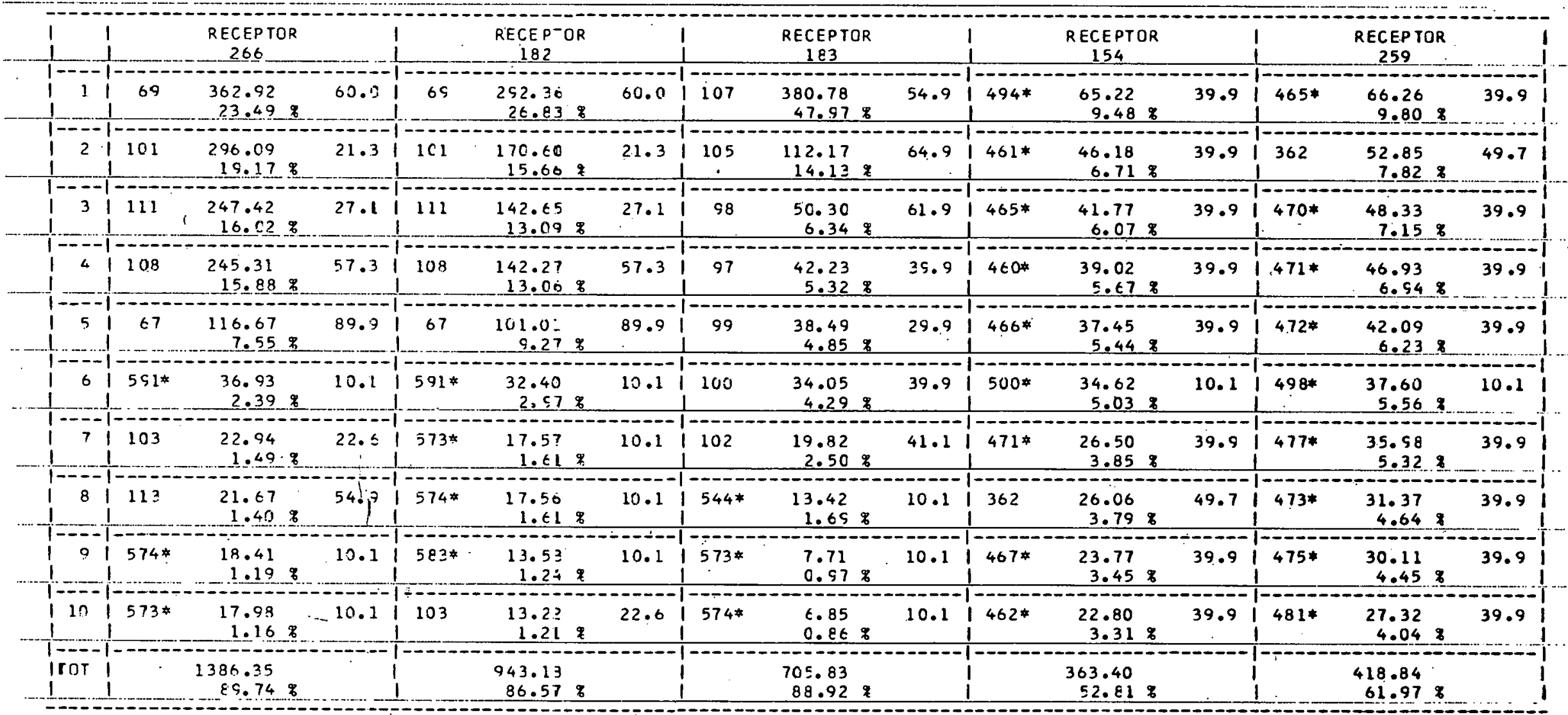

*Area source. 
TABLE XIII (Contd.)

CULPABILITY LIST

CHICAGQ NETRCPOLITAA AIR GUALITY_CONTROL REGICN

SFASDN DFC-FEB STABILITY CLASS 4 WINO DIRECTION SW $\quad$ WIND SPEED O - 3 KNOTS

SO2 FOR HIGHEST RECEPTORS I MICROGRAMS PER CUBIC METEF,

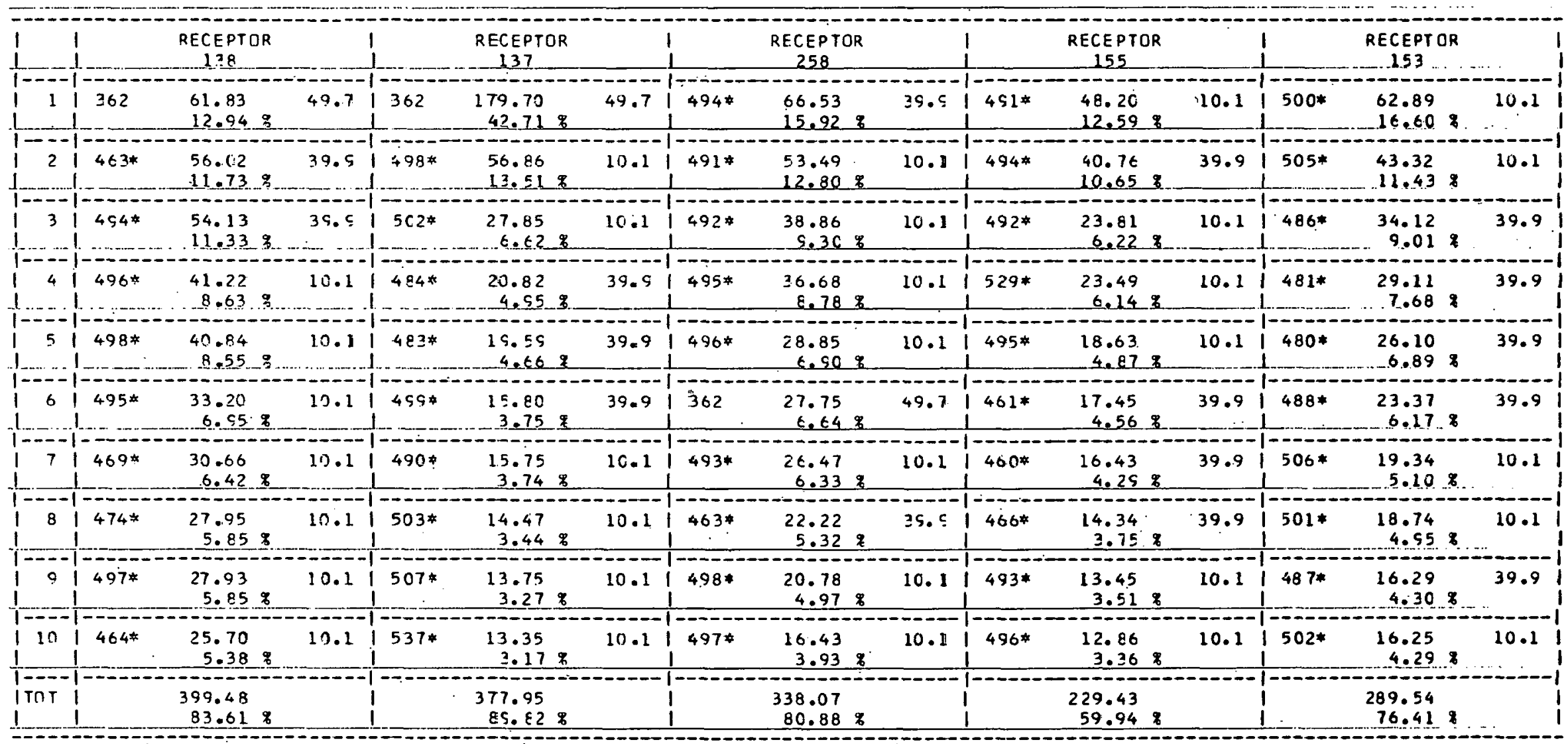


monitoring station, which has already shown a 24 -hour $\mathrm{SO}_{2}$ reading of $.45 \mathrm{ppm}$.

The source culpability lists of Table XVII are explained in Fig. 7. They show the sulfur dioxide contributions (pollutant value and percent) of the 10 highest point sources for the 5 highest receptor values in the region. For each source the source number, pollutant contribution, and effective stack height in meters are shown as indicated in Fig. 7. 3. Check Pollution Contours against Monitored Air Quality

Because the pollution contours are calculated using an uncalibrated steady-state diffusion model, the absolute value of the calculated data is open to question. In addition, plume behavior in an urban area does not always follow the "cook book." Therefore monitored air quality should be used to "field-calibrate" the calculated data to the existing situation. If no air quality data is available in the critical areas, then mobile monitoring equipment should be sited to assess the problem.

For this hypothetical episode the Whiting monitoring station would be checked to see if the levels calculated at receptor 266 were reached, and monitoring stations on the north side of Chicago (4, 5, and 19 in Fig. 5 should be checked to see if the levels calculated at receptor 259 (5th highest receptor figure) were reached.

4. Identify Culpable Sources

Culpability. lists that correspond to high pollution contours should be examined to identify controllable sources that can help the air quality by modifying their emissions. This should be done for every problem area in the region (high receptors in the culpability list).

In the case of the Chicago episode, the highest receptor (\#266) has a calculated value of approximately $.54 \mathrm{ppm}$, of which $82 \%$ is due to 5 point sources 
CHICAGO REGION $\mathrm{SO}_{2}-\mathrm{H}-\mathrm{NT}-\mathrm{SW}-3 \quad 1$

CHICAGO METROPOLITAN AIR QUALITY CONTROL REGION

SEASON DEC-FEB STABILITY CLASS 4 WIND DIRECTION SW

$\mathrm{SO}_{2}$ FOR HIGHEST RECEPTORS (MICROGRAMS PER CUBIC METER)

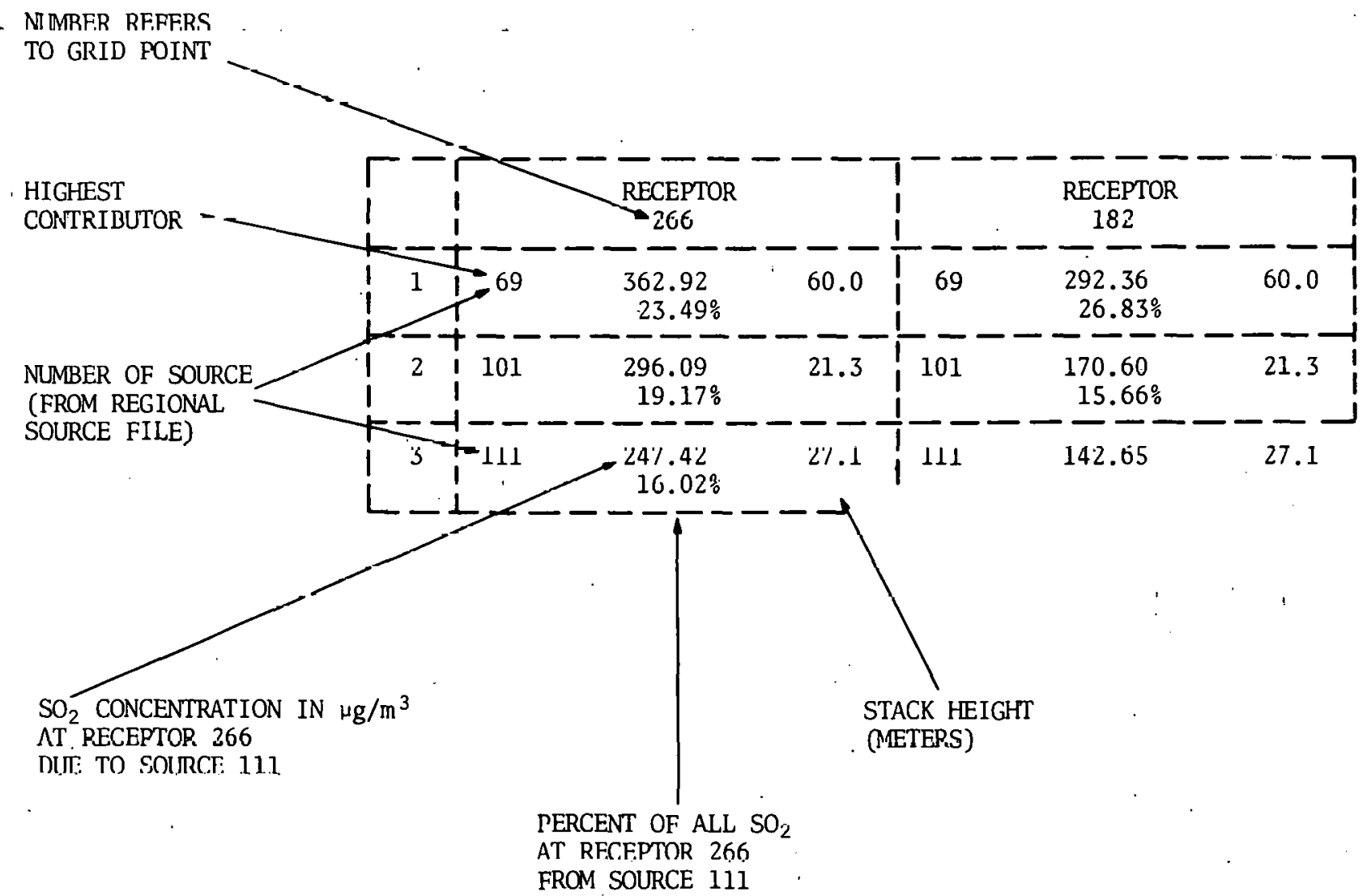

EACH AREA SOURCE IS DENOTED BY AN ASTERISK (*)

Fig. 7. Explanation of Source Culpability List 
(\#'s $69,101,111,108,67)$. These five sources combined emit over 80 tons of $\mathrm{SO}_{2}$ per day. Each of the other high receptors could be examined to determine the major cause of the problem. In the case of receptor \#138 (6th highest receptor), $70 \%$ of the problem is caused by area sources, which are probably space heating sources, and the only control strategy possible would be indoor temperature reductions. 5. Determine Control Strategy

After the nature and cause of the region's poor air quality has been determined, an episode control strategy will be instituted if necessary. The control strategy, both in severity and scope, is still basically at the discretion of the strategist, but identification of the problem has directed him to its causes.

In the case of the hypothetical episode, the 5 culpable sources could be controlled if it was determined that $\mathrm{SO}_{2}$ levels would soon exceed the $1.0 \mathrm{ppm}$ safety limit. This decision is then based upon the meteorological forecast and the reported air quality. This procedure could then be followed for each of the 10 highest receptors listed in the culpability list.

Planning episode control strategies can be performed on hard copies of the film pollution contours or shown on the display unit described in Appendix D. 
VI. EPILOGUE

At the conclusion of every system design effort the engineer, in retrospect, always has thoughts on how the system could be improved. This system is no exception and the epilogue represents a discussion of ways of improving the methodology for controlling air pollution episodes presented in this report.

The heart of the methodology is the steady-state dispersion model (ASSM), which was developed specifically for this system. It was not the intention to develop a model that predicts air quality levels closer to monitored values than other dispersion models, but to create a tool that would facilitate the need to identify the causes (sources) of the episode. That does not mean to say that ASSM was developed without any thought as to predictability, because a great deal of time was spent on improving the calculational ability of the model, but rather that the main thrust was directed at providing the information necessary to develop effective control strategies. Now that ASSM is a usable working model, more attention should be paid to the accuracy of the model in predicting air quality concentrations during poor meteorological conditions. At least a cursory validation effort should be performed using monitored air quality data. Because ASSM is driven by a steadystate diffusion algorithm the validation should be performed for cases and data approximating steady-state meteorological conditions. Attention should be given to the source emissions for the validation period to assure that they resemble the source inventory, which is based on an annual average.

One area in the diffusion algorithm where the authors feel ASSM could be deficient is the simulation of area sources. The fixed angle (22.5 degrees) 
that is used to calculate the vertical point source and subsequent source contributions may not always correctly simulate the effects of area sources. The PUFF program uses a different area source simulation technique that seems to work very well. It should probably be incorporated into the ASSM program in place of the present area source simulation model, which was originally designed to predict concentrations for averages and for single meteorological conditions.

The methodology presented in this report, although including several computer programs, is still a manual technique. With the aid of a remote graphical display computer terminal and some program modifications, the entire procedure could be automated. An IBM 2250 or similar graphical display terminal could be used; or, if access to a central computer were more difficult, then a unit with a viewing screen that retains an image could be utilized.

The basic idea would be to implement ASSM on a main computer and then access the program from a remote terminal. Pollution contours could be developed "on-line" and plotted on the viewing screen of the terminal. The advantage of having the model "on-1ine" rather than precalculated is that pollution contours could be derived for the "exact'meteorological conditions rather than for values based on historical data. This would be particularly useful in the case of the mixing height.

Once ASSM is implemented and available by remote terminal, several changes to the main program could automate the entire episode control strategy process. A calibration algorithm could be used to "rollback" the pollution contour levels using measured air quality. This would certainly give a better picture of the true air quality episode problems. One aid for developing control strategies would be a capability for removing culpable source contributions 
from the pollution contours and viewing the effect at the terminal. Control strategies would be developed by removing culpable sources, one by one, until the episode problems appear to be resolved. The results would certainly be more accurate and the control strategy development would be much quicker. 


\section{APPENDIX A}

Sample Lists and Computer Program Listings for the Regional Source File

1. Ordered List of $\mathrm{SO}_{2}$ Emitters in Chicago Region according to Jurisdiction Together with Its Program Listing

\begin{tabular}{|c|c|c|c|c|}
\hline$S C R C E$ & $\begin{array}{l}\text { SU2 }(T N / C A) \\
E M I S S I C A S\end{array}$ & $\begin{array}{c}\text { PART (TN/CA } \\
\text { EMISSIGAS }\end{array}$ & SOURCE NAME & $\begin{array}{l}\text { PCL I T } \\
\text { JUR I S }\end{array}$ \\
\hline 157 & 570.00 & 18.50 & $5 \mathrm{CO}^{\circ} 20^{\circ} \mathrm{COM}$ EDNEW JOLIET & 2 \\
\hline $16 \overline{2}$ & $31 t \cdot 50$ & 12.32 & $5 C 2300 \mathrm{CON}$ EDHILL CO 2 & 1 \\
\hline $16 C$ & $258 \cdot C C$ & 16.93 & COM EU WAUKEGAN & 1 \\
\hline 155 & $171 \cdot 5 \mathrm{C}$ & 1.30 & $5 C 0260$ CON EUCLO JOLIETI & $\mathrm{T}$ \\
\hline 161 & 150.01 & 6.45 & 502300 CCM EDWILL CO 1 & 1 \\
\hline $15 t$ & $85 \cdot 5 C$ & 39.00 & $5 C 0260$ CCM EDOLD JOLIET 2 & 1 \\
\hline 155 & $84 . \mathrm{CC}$ & 1.88 & $5 C 0200^{\circ}$ COM ED RTDGELAND & 1 \\
\hline 58 & 27.40 & 38.40 & JCLIET ARNY ANMO PLANT & 1 \\
\hline 4 & $23.3 \mathrm{C}$ & $\mathrm{C} . \mathrm{O}$ & $255070 \quad$ UNIRCYAL & 1 \\
\hline 194 & 21.36 & $\mathrm{C} \cdot 3 \mathrm{C}$ & $035 \angle 20$ CLARK REFIXERY & 1 \\
\hline 150 & 21.20 & 35.50 & $255070 \quad$ UNIRCYAL & 1 \\
\hline $1 \in 4$ & $1 \varepsilon .04$ & $12.5 \varepsilon$ & GREAT LAKES TKAIN,CTR. & $i$ \\
\hline 197 & 17.86 & $0.50^{-}$ & $317050^{-T E X A C O}$ TEFINERY & 1 \\
\hline 196 & 5.70 & 0.53 & 312370 PURE CIL CO & 1 \\
\hline 8 & $\varepsilon .7 \bar{L}$ & C. 46 & 035130 CHGO CU E CHEM & 1 \\
\hline 184 & 6.51 & 0.85 & 3548OC ABEOTT LABS NCGO & 1 \\
\hline 150 & 5.92 & 0.34 & 312170 ARGCNNE NATL LABS & 1 \\
\hline $2 \mathrm{C} 8$ & $E . \varepsilon C$ & C.92 & 286030 WYMAN-GCRDCN CO & 1 \\
\hline 136 & 5.56 & 0.45 & 295900 CATERPILLAR & 1 \\
\hline 202 & 5.25 & 3.19 & $3 C 2710$ GAF CORP 1 COAL & 1 \\
\hline 169, & 4.56 & $1.5 t$ & 5C8940 ELGIN STATE HOSP & 1 \\
\hline 7 & 4.26 & 0.0 & 295420 AMER CYANAATIO & 1 \\
\hline 132 & 3.85 & 1.23 & 453570 U.S. STEEL CGRP & $i$ \\
\hline 34 & $3 \cdot C .0$ & 0.33 & 452220 GM CRP-CHEVRCLET & 1 \\
\hline $17 C^{-}$ & $2.8 E$ & $0.8 \varepsilon$ & 507980 STATE-VTLLE PEN. & 7 \\
\hline $14 ?$ & 2.75 & 0.02 & 2C6S50 FGRD MCTOR CO & 1 \\
\hline 165 & 2.46 & 0.31 & FT.SHERICAN & 1 \\
\hline 200 & 1.89 & $2 \cdot 13$ & 45240C JCFINS-MANVILLE WT & 1 \\
\hline $18 \bar{c}$ & $1.8 z$ & 0.25 & $2 C 8420$ STAUFFER CHEMICAL & 1 \\
\hline 172 & $1 \cdot 65$ & 1.05 & 247630 KETRBER PACKING CO & 1 \\
\hline 773 & 7.45 & 0.02 & 448530 OVALTINE FCCD PRO- & $i$ \\
\hline 158 & 1.41 & C. $4 t$ & $5 C 7900$ HINNETKA MLN ELEC & 1 \\
\hline 140 & 1.37 & C. .97 & 461970 WOODSTOCK DIECAST & 1 \\
\hline 139 & 1.30 & 0.07 & 303220 US STEEL & 1 \\
\hline 204 & $1 . \mathrm{CC}$ & 0.32 & 416170 MULINE-NALLEABLE & 1 \\
\hline 145 & C. 56 & 0.30 & 2S8090 LENNCNHALL PAPER & 1 \\
\hline 128 & 6.82 & $0.30^{-}$ & $452280^{-}$GRISS-PFLEGER TAN & 1 \\
\hline 177 & C. .77 & C. CE & 012420 AURORA PAPERBCARD & 1 \\
\hline .142 & 0.66 & 0.12 & 458850 GM FISHER BOCY & 1 \\
\hline 127 & C.6O & 0.03 & O2E940 STANLARTU SCREN CO & 1 \\
\hline 207 & C. 56 & 0.05 & 430600 TELE TYPE CORP & 1 \\
\hline 168 & C. 55 & 0.38 & 037710 ROSSI $\quad$ E SCNS & 1 \\
\hline 165 & $C \cdot 4=$ & $c .04$ & $429940-5 E A R L E$ \& CC & $\overline{1}$ \\
\hline ISS & 0.38 & 0.02 & 206350 CERTAIN-TEED & 1 \\
\hline 145 & C. 37 & C.03 & 285790 SINCLAIR RESEARCH & 1 \\
\hline IदE & 0.35 & 0.02 & 505130 TRUMBUL ASPHALT & $T$ \\
\hline 181 & 0.35 & 0.05 & 321700 SMITH CHEMICAL WK & 1 \\
\hline 133. & C. .35 & 0.04 & 4524SO JOHNSIIN MOTORS & 1 \\
\hline 130 & $6 \cdot 33$ & 0.35 & $3552 \% 0^{-F A N S T E E L-M T L ~ C O R P-~}$ & $7^{-}$ \\
\hline 205 & $c .22$ & 0.05 & $2 C E G 20$ COLUHBIA TCOL STL & $i$ \\
\hline 182 & $C .3 \mathrm{C}$ & C.21 & 454380 AMER PCTASH CCRP & 1 \\
\hline 129 & 6.25 & 0.03 & 245710 CTICAGG RAFHICE & -1 \\
\hline
\end{tabular}




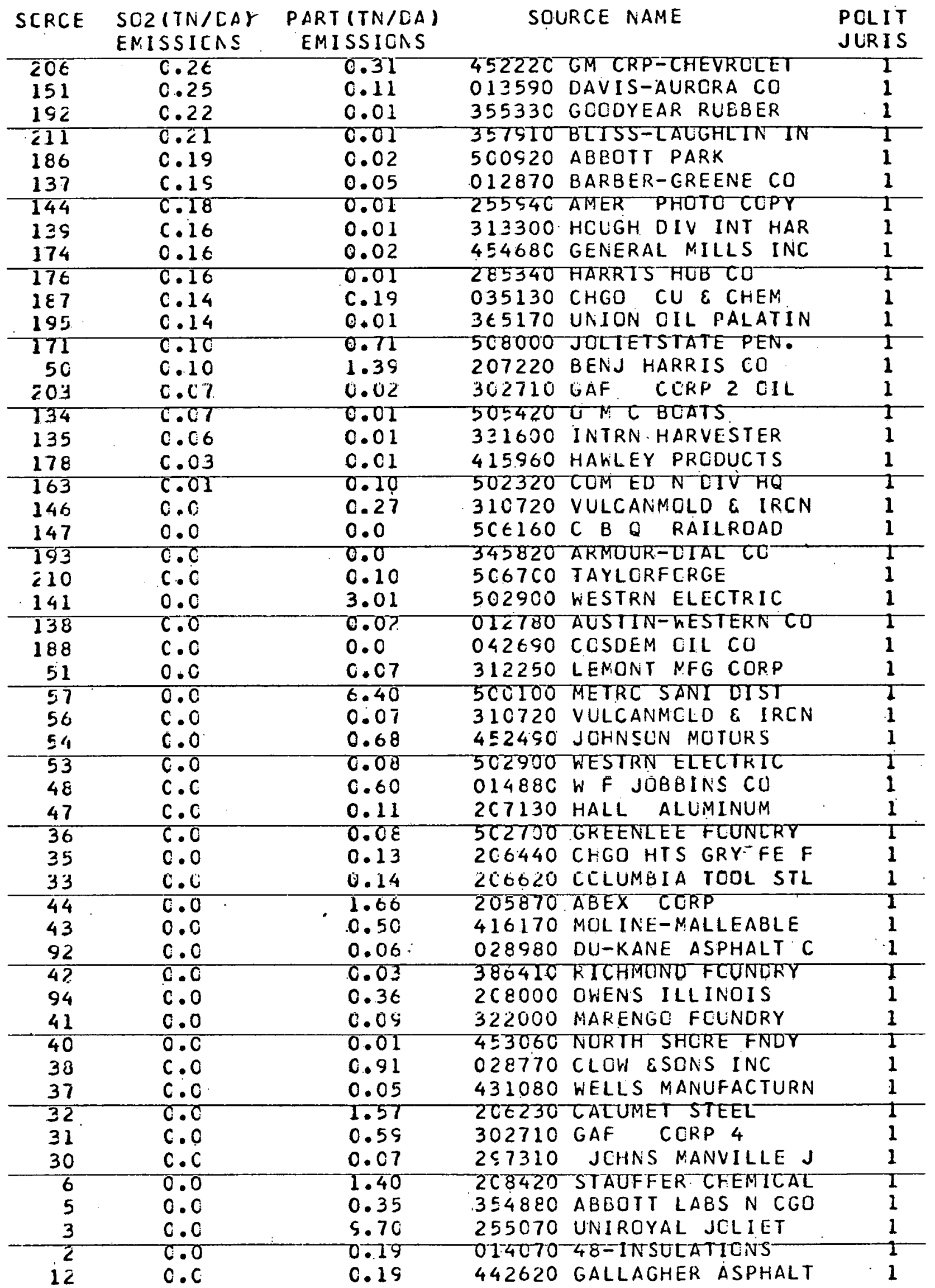




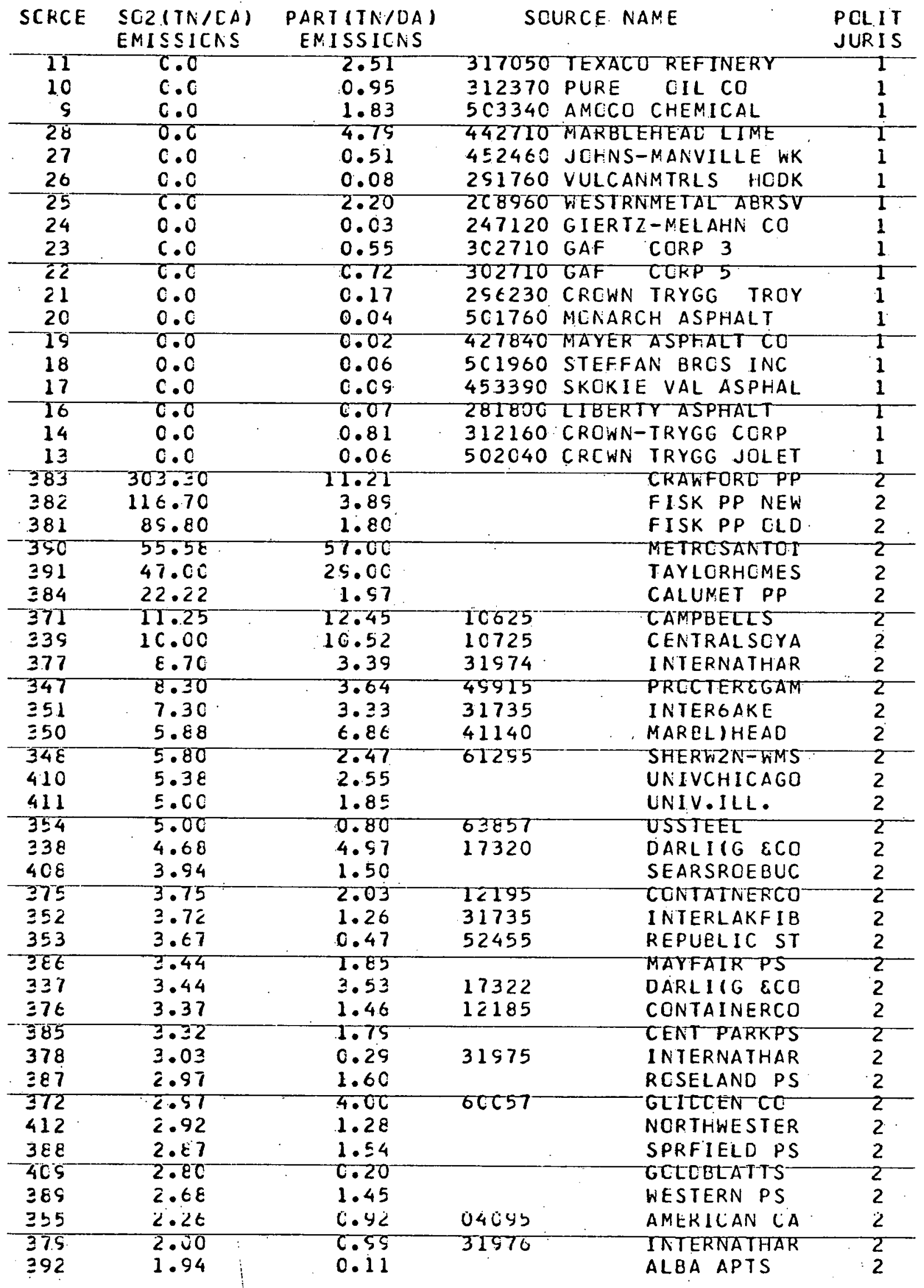




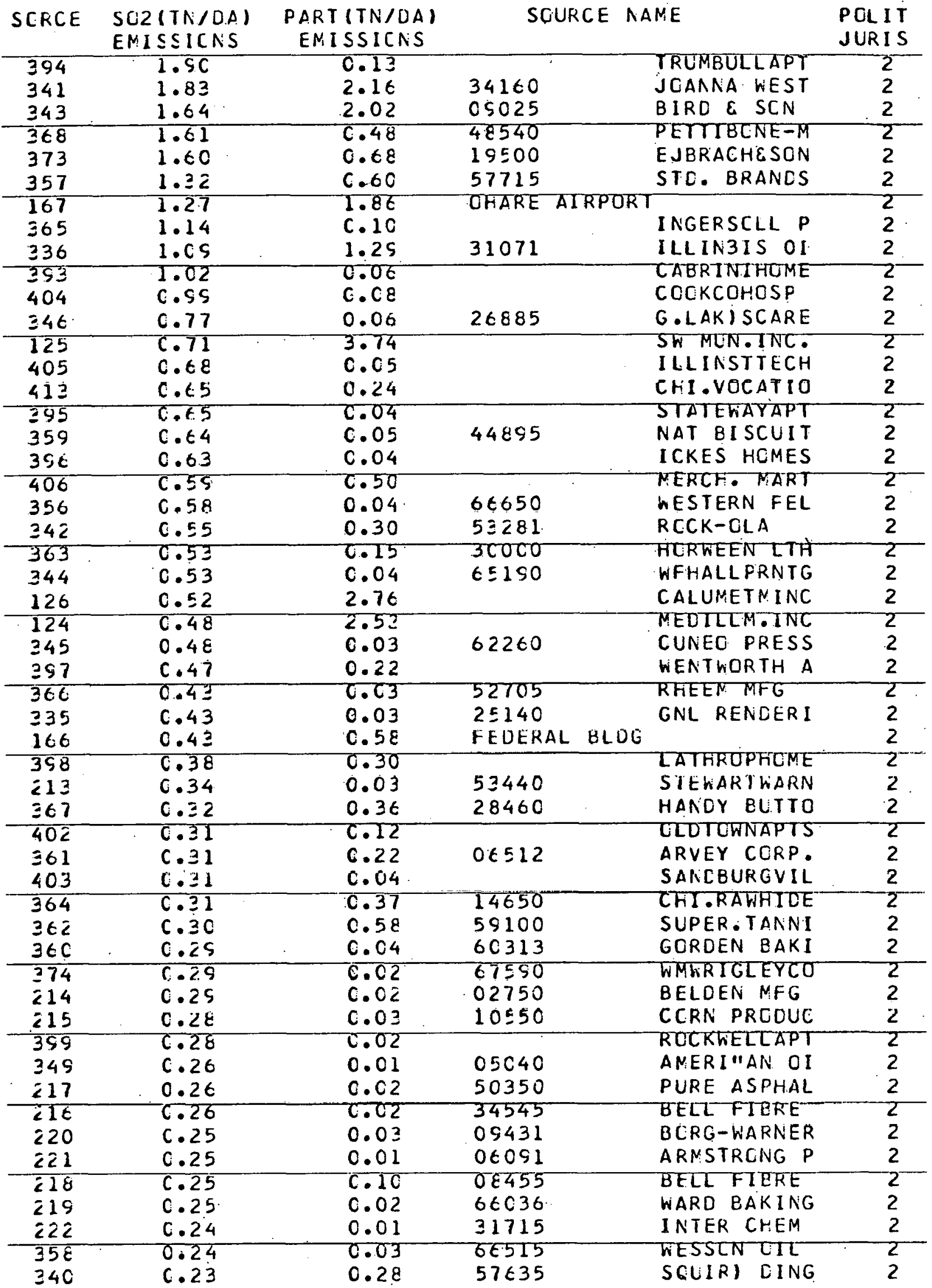




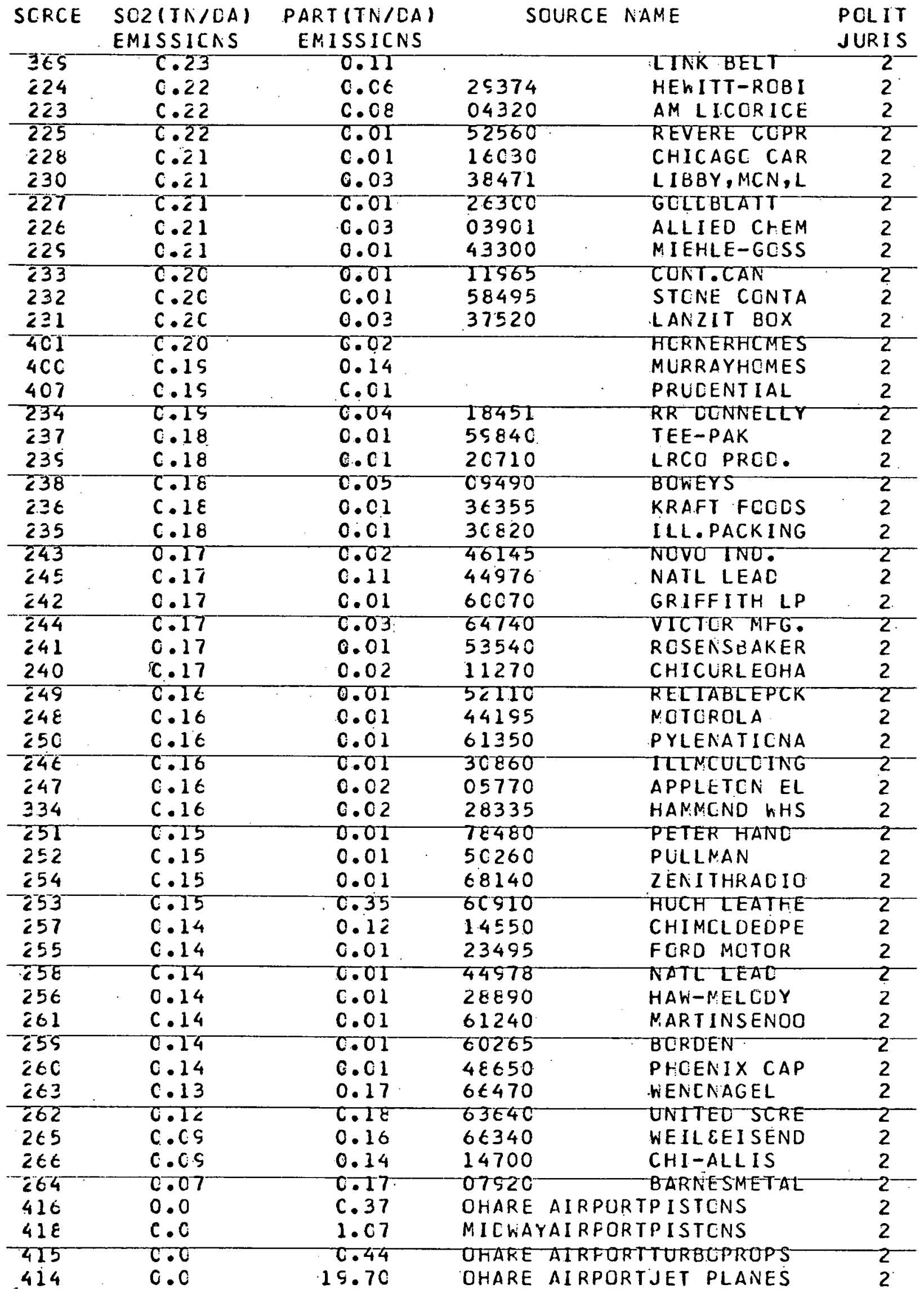




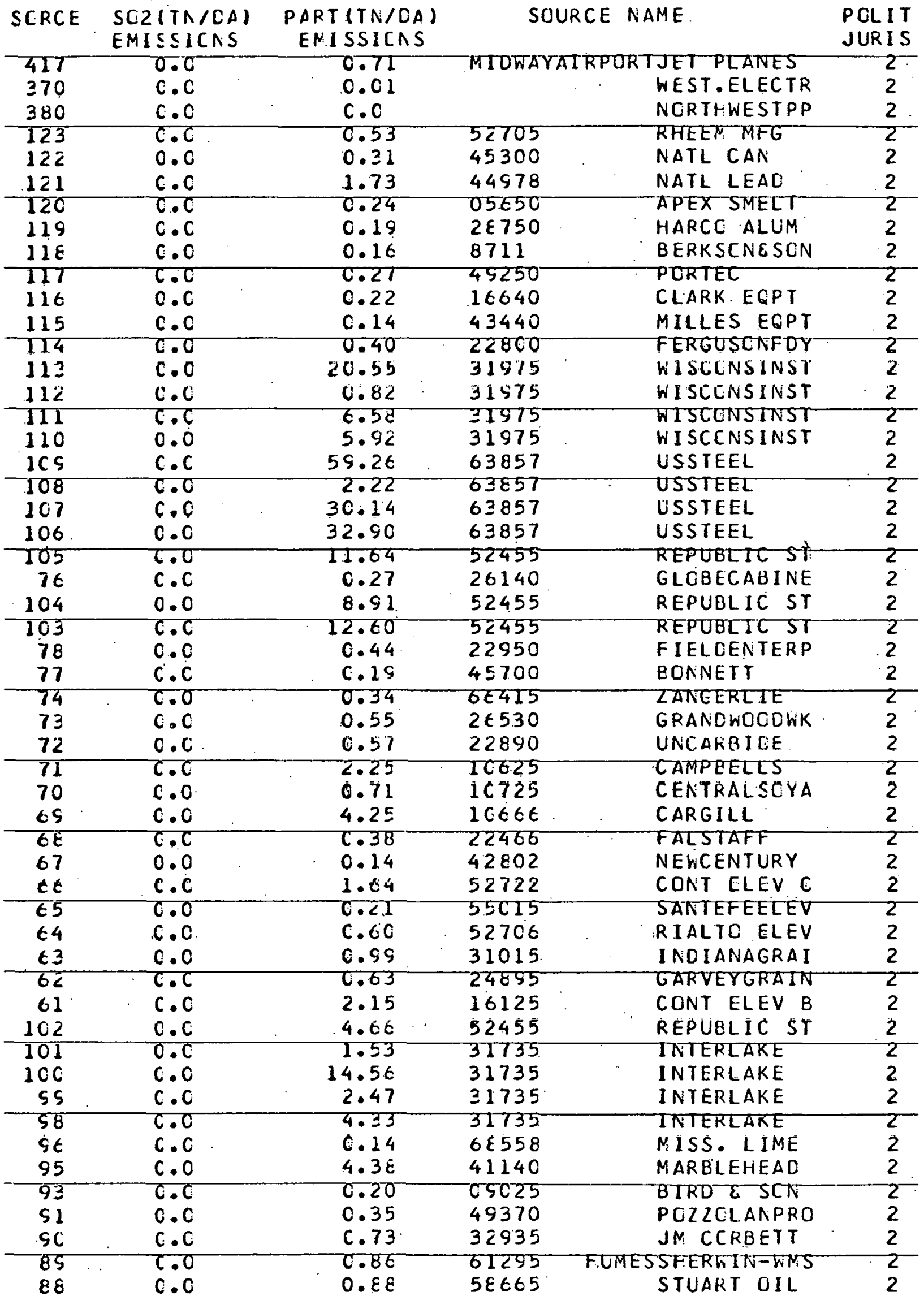




\begin{tabular}{|c|c|c|c|c|}
\hline SCRCE & $\begin{array}{l}S C 2(T A / C A) \\
E M I S S I C N S\end{array}$ & $\begin{array}{c}\text { PART (TA/DA) } \\
\text { ENISSICAS }\end{array}$ & SOURCE NAME & $\begin{array}{l}\text { PCLIT } \\
\text { JURIS }\end{array}$ \\
\hline $\begin{array}{l}75 \\
87 \\
\varepsilon t\end{array}$ & $\begin{array}{l}C \cdot C \\
C \cdot 0 \\
C \cdot C\end{array}$ & $\begin{array}{l}0.29 \\
0.15 \\
0.25\end{array}$ & $\begin{array}{l}\text { WFHALLPRNT6 } \\
\text { STEREOTYPE } \\
\text { MIXSTALFFERCFE }\end{array}$ & $\begin{array}{l}2 \\
2 \\
2\end{array}$ \\
\hline $\begin{array}{l}45 \\
85 \\
84\end{array}$ & $\begin{array}{l}C .0 \\
C . C \\
C . C\end{array}$ & $\begin{array}{l}0.35 \\
C .14 \\
C .31\end{array}$ & $\begin{array}{l}\text { HCWARD FCY } \\
\text { MILLSSTALFFERCHE } \\
\text { STDPASTEEGL }\end{array}$ & $\begin{array}{l}2 \\
2 \\
2\end{array}$ \\
\hline $\begin{array}{l}83 \\
82 \\
75\end{array}$ & $\begin{array}{l}C \cdot C \\
C \cdot C \\
C \cdot O\end{array}$ & $\begin{array}{l}0.65 \\
0.46 \\
0.16\end{array}$ & $\begin{array}{l}\text { MURTCN SALT } \\
\text { BLACK PROD } \\
\text { TURNER MFG }\end{array}$ & $\begin{array}{l}2 \\
2 \\
2\end{array}$ \\
\hline $\begin{array}{l}6 C \\
55 \\
81\end{array}$ & $\begin{array}{l}C \cdot C \\
C \cdot C \\
C \cdot C\end{array}$ & $\begin{array}{l}0.27 \\
0.61 \\
0.46\end{array}$ & $\begin{array}{l}\text { CONT ELEVA } \\
\text { DIXIEMILLS } \\
\text { HANDSCHYCHE }\end{array}$ & $\begin{array}{l}2 \\
2 \\
2\end{array}$ \\
\hline $\begin{array}{l}86 \\
175 \\
154\end{array}$ & $\begin{array}{l}0.0 \\
35.50 \\
0.85\end{array}$ & $\begin{array}{l}0.23 \\
3.00 \\
0.01\end{array}$ & $\begin{array}{l}\text { OE } 2307 R C C \text { CARO } \\
\text { CCS340 CCRN PRCDUCTS } \\
\text { BFD PK JOFNSON E JOHNSCN }\end{array}$ & $\begin{array}{l}2 \\
3 \\
3\end{array}$ \\
\hline $\begin{array}{l}185 \\
191 \\
212\end{array}$ & $\begin{array}{l}0.82 \\
0.44 \\
0.43\end{array}$ & $\begin{array}{l}0.05 \\
0.07 \\
0.40\end{array}$ & $\begin{array}{l}\text { BFU PK NALCU CREMICAL CO } \\
\text { BFC PK UNION CARBIDE } \\
\text { BFD PK CCNTNL CAN CO }\end{array}$ & $\begin{array}{l}3 \\
3 \\
3\end{array}$ \\
\hline $\begin{array}{l}152 \\
179 \\
153\end{array}$ & $\begin{array}{l}C \cdot 25 \\
C .28 \\
C .26\end{array}$ & $\begin{array}{l}0.02 \\
0.04 \\
0.01\end{array}$ & $\begin{array}{l}\text { BFC PK MILES LABS } \\
\text { BFC PK M M M CO } \\
\text { BFC PK BORG \& BECK DIV }\end{array}$ & $\begin{array}{l}3 \\
3 \\
3\end{array}$ \\
\hline $\begin{array}{r}2 C 5 \\
180 \\
1\end{array}$ & $\begin{array}{l}0.23 \\
0.1 \varepsilon \\
0.0\end{array}$ & $\begin{array}{l}C .02 \\
0.01 \\
4.75\end{array}$ & $\begin{array}{ll}\text { BFD PK CLMRL } & \text { STANPTNG } \\
\text { BFC PK H P } & \text { SMITH PAPER } \\
\text { OCS340 CORN } & \text { PRCCUCTS }\end{array}$ & $\begin{array}{l}3 \\
3 \\
3\end{array}$ \\
\hline $\begin{array}{l}52 \\
148 \\
201\end{array}$ & $\begin{array}{l}0.6 \\
5.60 \\
3.84\end{array}$ & $\begin{array}{l}0.01 \\
0.66 \\
0.75\end{array}$ & $\begin{array}{l}336370 \text { HARPER CC } \\
3 C 7690 \text { GM CORP LAGRANGE } \\
\text { NCCOCK STANDARE LIME }\end{array}$ & $\begin{array}{l}4 \\
5 \\
5\end{array}$ \\
\hline $\begin{array}{l}49 \\
46 \\
55\end{array}$ & $\begin{array}{l}0.0 \\
0.0 \\
C . C\end{array}$ & $\begin{array}{r}12.10 \\
6.65 \\
c .23\end{array}$ & $\begin{array}{l}\text { MCCCOK KEYNOLCS METALS } \\
\text { MCCCCK PIELET BRCS } \\
\text { MCCOCK MCCOCK CRUM \& BBL }\end{array}$ & $\begin{array}{l}5 \\
5 \\
5\end{array}$ \\
\hline $\begin{array}{l}57 \\
29 \\
15\end{array}$ & $\begin{array}{l}0.0 \\
C . C \\
0.0\end{array}$ & $\begin{array}{r}30.0 C^{-} \\
25.50 \\
C .03\end{array}$ & $\begin{array}{l}\text { WCCCCK NATERTAL SERVTCE- } \\
\text { MCCOCK STANOARE LINE } \\
5 C 1480 \text { GEO H HARTCNG INC }\end{array}$ & $\begin{array}{l}5 \\
5 \\
5\end{array}$ \\
\hline $\begin{array}{l}330 \\
331 \\
\equiv 22\end{array}$ & $\begin{array}{r}37 E \cdot C C \\
2 E: 5 C \\
4.57\end{array}$ & $\begin{array}{l}1.14 \\
0.12 \\
0.61\end{array}$ & $\begin{array}{l}\text { CLN EDTSUN STATE LINE } \\
\text { N.IPSCD BURNSHARBCR } \\
\text { BETHLEHEN ST. EEL BCILERS }\end{array}$ & $\begin{array}{l}6 \\
6 \\
6\end{array}$ \\
\hline $\begin{array}{l}33 \\
323 \\
428\end{array}$ & $\begin{array}{l}\text { C.S5 } \\
\text { C.St } \\
96.25\end{array}$ & $\begin{array}{l}0.02 \\
0.20 \\
0.0\end{array}$ & $\begin{array}{l}\text { PLRTER MEN } \\
\text { MIDWESTSTEEL } \\
\text { ANCCO WHIT ING }\end{array}$ & $\begin{array}{l}6 \\
6 \\
7\end{array}$ \\
\hline $\begin{array}{l}271 \\
451 \\
457\end{array}$ & $\begin{array}{l}1.5 . C C \\
C . C \\
0.0\end{array}$ & $\begin{array}{l}6.22 \\
0.54 \\
C .33\end{array}$ & $\begin{array}{l}\text { UNION CARBILEWHTTING COM } \\
\text { KEEN FNDRY GRAY IRCN } \\
\text { AMER SMELTINGAND REFIN }\end{array}$ & $\begin{array}{l}7 \\
7 \\
7\end{array}$ \\
\hline $\begin{array}{l}422 \\
\equiv 32 \\
321\end{array}$ & $\begin{array}{l}C \cdot C \\
267 \cdot C C \\
118 \cdot C C\end{array}$ & $\begin{array}{r}.0 .25 \\
5.40 \\
39.88\end{array}$ & $\begin{array}{l}\text { UNTON CARBITE WHTTING } \\
\text { MITCHELL FOWER PLANT } \\
\text { US STEEL COALFCR FUEL }\end{array}$ & $\begin{array}{l}7 \\
8 \\
8\end{array}$ \\
\hline $\begin{array}{l}220 \\
4 \equiv 2 \\
433\end{array}$ & $\begin{array}{l}85.5 C \\
36.50 \\
24.11\end{array}$ & $\begin{array}{r}3.26 \\
1 C 2.00 \\
5 C .20\end{array}$ & $\begin{array}{l}\text { US STEEL CIL CONBLSTICN } \\
\text { UNIV ATLAS CENENT MILL } 6 \\
\text { US STEEL ATLASHAREOR }\end{array}$ & $\begin{array}{l}8 \\
8 \\
8\end{array}$ \\
\hline $\begin{array}{l}328 \\
435 \\
445\end{array}$ & $\begin{array}{l}C .55 \\
C .0 \\
C .0\end{array}$ & $\begin{array}{l}0.21 \\
85.50 \\
64.40\end{array}$ & $\begin{array}{l}\text { SCREW BOLT CCRP OF AM- } \\
\text { US STEEL CPENHEARTHS } \\
\text { US STEEL SINTERING PLANT }\end{array}$ & $\begin{array}{l}8 \\
8 \\
8\end{array}$ \\
\hline $\begin{array}{l}443 \\
444\end{array}$ & $\begin{array}{l}C \cdot C \\
C . C\end{array}$ & $\begin{array}{r}10.40 \\
1.23\end{array}$ & $\begin{array}{l}\text { US STEEL BLAST FUKNACE I } \\
\text { US STEEL BOF }\end{array}$ & $\begin{array}{l}8 \\
8\end{array}$ \\
\hline
\end{tabular}




\begin{tabular}{|c|c|c|c|c|c|}
\hline$S C R C E$ & $\begin{array}{l}\text { SC2 }(T N / C A) \\
E M_{I} I S S I C A S\end{array}$ & $\begin{array}{c}\text { PARTITA/CA) } \\
\text { ENISSICNS }\end{array}$ & SOURCE NA & IME & $\begin{array}{l}\text { PCLIT } \\
\text { JURIS }\end{array}$ \\
\hline $\begin{array}{l}280 \\
285\end{array}$ & $\begin{array}{l}6 \varepsilon . C C \\
51.7 C\end{array}$ & $\begin{array}{r}1.53 \\
10.40\end{array}$ & $\begin{array}{l}\text { ATLANTIC } \\
\text { INLAND STEEL }\end{array}$ & $\begin{array}{l}\text { BOTLERS } \\
\text { PWR GEN } 401\end{array}$ & $\begin{array}{l}9 \\
9\end{array}$ \\
\hline$\equiv 19$ & 42.30 & 34.30 & YAGSThN ST & STEEL PL & 9 \\
\hline $\begin{array}{l}421 \\
268\end{array}$ & $\begin{array}{l}35 \cdot 0 C \\
22 \cdot 52\end{array}$ & $\begin{array}{l}0.0 \\
3.20\end{array}$ & $\begin{array}{l}\text { DUPCNT } \\
\text { UNION CARBICE }\end{array}$ & $\begin{aligned} & \text { SULF AC MFG } \\
= & L \text { INCE CCMB }\end{aligned}$ & $\begin{array}{l}9 \\
9\end{array}$ \\
\hline 427 & $22 \cdot 30$ & 1.20 & ANOCO WHIT & FCC CAT REG & 9 \\
\hline 282 & 20.02 & 0.16 & CIT SER & BOTLERS & 9 \\
\hline 277 & 16.70 & 0.16 & MCEIL CIL REF & ECILERS & 9 \\
\hline $27 \mathrm{C}$ & 15.43 & c. 17 & UNION CAREICE & EPOLYETHYLEN & 9 \\
\hline 281 & 13.96 & 4.82 & ANCCO WHIT & BCILERS & 9 \\
\hline 291 & $13 \cdot 6 C$ & 0.0 & INLANC STEEL & COKE OVN 2 & 9 \\
\hline 304 & $12 \cdot \in C$ & 1.11 & INLANC STEEL & 80 STRIP ML & 9 \\
\hline 423 & 12.51 & $\mathrm{c} .0$ & ATLANTIC & FCC STRTP & 9 \\
\hline 293 & 11.74 & C.C & IALANC STEEL & OPN HRTH 2 & 9 \\
\hline 274 & $11.4 \mathrm{C}$ & c. 0 & ATLANTIC & GAS CEA ABS & 9 \\
\hline 255 & $1 \mathrm{CC} \cdot 30$ & 0.33 & TNLANL STEEL & MILLS 2 & 9 \\
\hline 424 & $1 \mathrm{C} .0 \mathrm{C}$ & 0.0 & ANCCO WHIT & SULF REC & 9 \\
\hline 275 & 8.13 & 0.0 & CIT SER & SOUR STRIP & 9 \\
\hline 279 & $6.8 \mathrm{C}$ & 0.0 & CITIES SERVIO & CHZS SCRUBBE & 9 \\
\hline 430 & $\epsilon . \varepsilon C$ & 0.0 & CIT SER & GIRBCTCL & 9 \\
\hline $27 t$ & 6.77 & 0.0 & AMOCO WA I T & SGLR STRIP & 9 \\
\hline 299 & $t .64$ & 0.50 & TNLAND STEEL & $76: S T R I P$ ML & 9 \\
\hline 425 & $5 . \notin 7$ & 3.30 & ATLANTIC & FCC RESEN. & 9 \\
\hline 290 & $=. \varepsilon C$ & 0.0 & INLANC STEEL & CEKE OVN 3 & 9 \\
\hline 296 & 5.77 & 0.24 & INLANL STEEL & BLM MILL 3 & 9 \\
\hline 216 & E.23 & C.1S & YNGSTHN S T & COKE PLANT & 9 \\
\hline 207 & 4.90 & $0.0 \epsilon$ & IMLAND STEEL & $P W R$ GEN 301 & 9 \\
\hline$\angle S E$ & 4.ET & 0.32 & TILANC. STEEL & 44 STRIP ML & 9 \\
\hline $20 E$ & $4 \cdot 20$ & $6.6 \varepsilon$ & YNGST STEEL & POW ST PT & 9 \\
\hline 294 & 3.55 & 0.09 & INLAND STEEL & MILLS 1 & 9 \\
\hline 303 & 2.48 & 0.06 & INLAND STEEL & $14 \mathrm{IN}$ MILL & 9 \\
\hline 292 & 2.14 & 0.01 & INLANC STEEL & CPH HRTH 3 & 9 \\
\hline 201 & 2.03 & C. 04 & INLAND STEEL & CGL'D STRIP & 9 \\
\hline 285 & T.Eह & $0.13 \ldots$ & TNLANU STEEL & PLATE MILL & 9 \\
\hline$\equiv 15$ & 1.6 .3 & 0.34 & YAGSTHN S T & GPEN HERTHI & 9 \\
\hline 297 & $1 .-1$ & C. 0 & INLAND STEEL & SLAB MILL 4 & 9 \\
\hline 288 & 1.41 & 0.02 & IKLANC STEEL & PGR GEN 305 & 9 \\
\hline 213 & 1.14 & 0.10 & YNGSTHN S. T & BLMG MILL 2 & 9 \\
\hline $2 \varepsilon \epsilon$ & 1.07 & 0.02 & INLANC STEEL & 10 IN MILL & 9 \\
\hline 425 & C.90 & 0.73 & MCBIE CIL & CAT REGEN & 9 \\
\hline 314 & C. .77 & 0.0 & YNESTKN S T & CPEN HTH 2 & 9 \\
\hline 305 & $c .7 c$ & 0.07 & YNGSTKN S T & UTIL BLIL 3 & 9 \\
\hline$\equiv \mathrm{CO}$ & $C . t E$ & 0.01 & IKLAND STEEL & TIN $N_{i} I L L$ & 9 \\
\hline 207 & $c .63$ & 0.02 & YNGSTKN S T & SHT NILL 2 & 9 \\
\hline 426 & & 1.25 & CIT SER & FCC REGEN & 9 \\
\hline 431 & $0.6 \mathrm{C}$ & C.O & CIT SER & CAUS REEEN & 9 \\
\hline 284 & $C \cdot 54$ & 0.08 & INLAND STEEL & PWR GEN 211 & 9 \\
\hline$\equiv 12$ & $C .46$ & 0.06 & YAGSTHN S T & BLCCN NC 1 & 9 \\
\hline 305 & 0.45 & 0.19 & YNGSTRN ST & 84 IN STRIP & 9 \\
\hline 273 & C.4.5 & $C .0$ & MCBIL OIL & FLARE & 9 \\
\hline$\equiv 10$ & 0.42 & 0.03 & YNGSThN S T & SMLSS PIPE & 9 \\
\hline $28 ?$ & $C .36$ & 0.0 & TAZANC STEEL & BLKSMTH SHP & 9 \\
\hline & & & YNGSTN S T ME & EP $\quad \mathrm{N} I \mathrm{ILL}$ & 9 \\
\hline
\end{tabular}




\begin{tabular}{|c|c|c|c|c|}
\hline SCRCE & $\begin{array}{l}\text { SC2 (TN/CA) } \\
\text { EMIS SICAS }\end{array}$ & $\begin{array}{l}\text { PART (TN/DA) } \\
\text { EMISSICNS }\end{array}$ & SCURCE NAME & $\begin{array}{l}\text { POLIT } \\
\text { JURIS }\end{array}$ \\
\hline $\begin{array}{l}217 \\
454\end{array}$ & $\begin{array}{l}\mathrm{C} \cdot 3 \mathrm{I} \\
\mathrm{C} \cdot 3 \mathrm{C}\end{array}$ & $\begin{array}{l}C .09 \\
0.0\end{array}$ & $\begin{array}{l}\text { YAGSTWN S T SFEET HIZLC } \\
\text { US LEAD REFINERY }\end{array}$ & $\begin{array}{l}9 \\
9\end{array}$ \\
\hline$\equiv 27$ & $C .2 \bar{C}$ & $C . C 2$ & STAND FORGE BCILERS OIL & 9 \\
\hline $2 \mathrm{C2}$ & $C .14$ & 6.0 & INLAND STEEL SPIKE MILL & 5 \\
\hline 420 & C.14 & c. 22 . & UAICN CARBIDE PRCCESS & 9 \\
\hline$\Xi 25$ & C. 13 & 0.0 & US LEAD REFINERY INC & 9 \\
\hline 206 & 0.04 & 0.01 & YNGSTWNS T TIN NTLLI & 9 \\
\hline 318 & C. C & $c \cdot t 8$ & YNGSTHN S T & 9 \\
\hline 448 & $C .0$ & 1.54 & INLAND STEEL SCARANG & 9 \\
\hline 442 & C.C & C.CE & YIGST S T SCARFINE 2 & 9 \\
\hline 445 & C. 0 & $0.8 \mathrm{C}$ & INLAND STEEL SINTERING & 9 \\
\hline 452 & $c \cdot c$ & C. 20 & ANER STEEL FOUNCRIES IHW & 9 \\
\hline 439 & $\mathrm{C} \cdot \mathrm{C}^{-}$ & 1.00 & INLANC STEEL SINTERING O & 9 \\
\hline 447 & C. 0 & 0.40 & I MLAND STEEL CP HE PL 3 & 9 \\
\hline 436 & C. 0 & 1.15 & YAGSTN ST SCARFING 1 & 9 \\
\hline $45 \varepsilon$ & $\mathrm{C} \cdot \mathrm{C}$ & 0.58 & STANO FUREE PUSFER FCE & 9 \\
\hline $\begin{array}{l}455 \\
438\end{array}$ & $\begin{array}{l}C .0 \\
C . C\end{array}$ & $\begin{array}{l}0.50 \\
1.13\end{array}$ & $\begin{array}{ll}\text { US REC } & \text { CHLOR } \\
\text { IALANC STEEL } & \text { BCFS }\end{array}$ & $\begin{array}{l}9 \\
9\end{array}$ \\
\hline 440 & $\mathrm{C} \cdot \mathrm{C}$ & $17.30^{-}$ & TNEANC STEEL COKING PL & 9 \\
\hline 459 & C. C & 0.80 & STAND FORGE & 9 \\
\hline 456 & 0.0 & 0.12 & US RED SECCA AL & 9 \\
\hline 453 & $\mathrm{C} \cdot \mathrm{C}$. & 0.14 & ANER STEEL FCUNCRY IHW & 9 \\
\hline 434 & $\mathrm{C} \cdot \mathrm{C}$ & 1.19 & YAGSTHN ST SINTERING & 9 \\
\hline $44 t$ & 0.0 & $0 . t 6$ & US STEEL CCKE PLANT & 9 \\
\hline 437 & $C \cdot C^{-}$ & $0.71^{-}$ & INLAND STEEL BLAST FURN & 9 \\
\hline 441 & $\mathrm{C} .0$ & 20.60 & INLANC STEEL OP H PL 2 & 9 \\
\hline 419 & $22.7 c$ & 0.01 & STAUFFER CHEMICAL CO & 10 \\
\hline 324 & $1.4 E$ & $C \cdot 36$ & ANERICAN STEEL FCUNDRIES & 10 \\
\hline 272 & 1.32 & C. 93 & LEVER BRCTHERS & 10 \\
\hline 229 & C. 44 & $C . C Z$ & UN TANK CAR & 10 \\
\hline 267 & 0.14 & 0.01 & SIIFT COFUEL & $10^{-}$ \\
\hline$\equiv 26$ & $C \cdot 12$ & 0.01 & TAYLCR CHAIN & 10 \\
\hline 265 & C.11 & C. 0 & STAUFFER CHEMCO. FUEL & 10 \\
\hline 278 & $C \cdot 11$ & $\mathrm{C.C1}$ & W1TCO CHENIC AL FUEL & 10 \\
\hline 450 & $C \cdot C$ & 0.76 & HARBISCN WN KER REFRACT & 10 \\
\hline 39 & C. $C^{\prime}$ & 0.58 & 249040 WOODRUFF-ECWAROS & 10 \\
\hline
\end{tabular}


$X / C H I P 7$ JOB (F12844, 45,9,12, 'MARY SNIDER'. MSGLEVEL $=1$.

I) REGION=3GGK, CLASS $=\mathrm{B}$

CROKE E 12383 E5782-6E190

I SETUP DDNAME $=$ DUM1, DEVICE $=231 \%, I D=D I S K 59$

I PROCESS MAIN

/XPROCESS PRINT

/ FORMAT PR. DDNAME $=$ FTEGFEO1, COPIES $=5$

//STEP2 EXEC SORTD.

//SORTIN DD DSN=INSORCES, UNIT $=D I S K, D I S P=(O L D . K E E P), V O L=S E R=D I S K 59$

//SORTOUT DD DSN=INSORC 10. UNI T =DISK. DISP $=($ OLD,$K E E P), V O L=S E R=D I S K 59$

//SORTWKE1 DD UNIT =DISK, SPACE = (TRK, (20B), ,CONTIS)

//SORTWKE2 DD UNIT = (DISK, , SEP=SORTWKE1), SPACE $=($ TRK, (2EQ) , , CONTIG)

//SORTWKE3 DD UNIT = (DISK, ,SEP = (SORTWKE1, SORTWKER $)$.

I/ SPACE $=$ (TRK, (2QG) , CONTIG)

//SORTWKE4 DD UNIT $=$ (DISK. SEP $=$ (SORTWKB1, SORTWKE2, SORTWKE3) ),

// SPACE $=(T R K,(2 E G) ;$, CONTIG)

//SYSIN DD

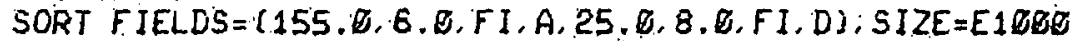

END

istis

//STEP3 EXEC FTGCLE

IIFTE. SYSIN DD

DIMENSION SORCE (7, 1EBO). PLUME (3, 1EEE), CSORCE (14, 1EG6)

DIMENSION SORCNO(1GEO), SRCNM(B, 1GEO)

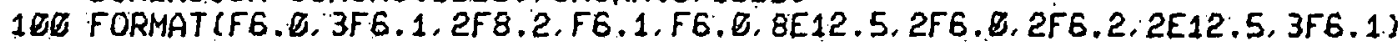
$I=0$

$1 I=I+1$

READ (19, 180. END =2) SORCNO(I), (SORCE (J, I), J=1, 7), (CSORCE (J) I),

$1 J=1,14)$; (PLUME (J, IJ, J $=1,3$ )

IF (SORCE ( ) I ) .EQ.9999.8) I =I-1

GO TO 1

2 CONTINUE

NSORCE $=I-1$

$\operatorname{REAB}(11,12, \operatorname{END}=116)((\operatorname{SRCNM}(I, J), I=1, \overline{8}), j=1, \mathrm{NSORCE})$

12 FORMAT (3A4, A1)

110 LINE $=\mathscr{B}$

WRITE $(6,1080)$

DO $1100 \mathrm{I}=1$, NSORCE

LINE $=$ LINE +1

ITCLIAIC.LT. S3) $00^{\circ}$ TO 1101

WRITE $(6,10 E 0)$

LINE $=\mathbb{E}$

1101 CONTINUE

SORCE $(1, I)=\operatorname{SORCE}(1, I) \ddot{*}, 6241$

$\operatorname{SORCE}(2, I)=S O R C E(2, I), 6241$

I.SORCE $=$ SORCNO (J)

WRITE (6, 1601) SORCNO (I) SORCE (4. 1), SORCE (5. I). CSORCE (1E, I),

1 SORCE ( ), I), CSORCE (3, I), CSORCE (4, I), CSORCE (14, I). (SRCNM (J. ISORCE)

2. $J=1,8)$

1100 CONTINUE

$10 E 0$ FORMAT (1H1, 5HSORCE, $3 X, 16 \mathrm{H}$ SO2 EMISSION

1 21HPART EMISSION POLIT, TH SIC.4X,11HANNUAL COAL,

$215 \mathrm{H}$ ANNUAL OIL $15 \mathrm{H}$. ANNUAL GAS,

$3 / 1 E X, 16 H$ RATE TN/DAY . 2QH RATE TN/DAY JURIS.

$47 \mathrm{H}$ CODE, 15H RATE TN/DAY, $15 \mathrm{H}$ RATE GAL $/ D A$.

$515 \mathrm{H}$ RATE FT3/DA/i

1801 FORMAT (1H, F6. $0.2(3 X, E 12.5), 2(3 x, F 5,6), 3(3 x, E 12.5)$,

$15 \times .2(3 A 4 . A 1)$ )

STOP

END

1

/ BO.FT1BFEE1 DD DSN=INSORC1D, UNIT=DISK,DISP=(OLD, KEEP,$V O L=S E R=D I S K 59$

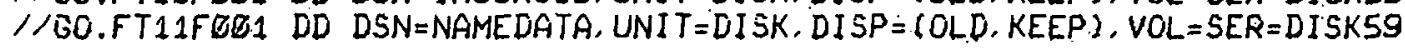

1 
2. Ordered List of $\mathrm{SO}_{2}$ Emitters in Chicago Region Together with Its Program Listing

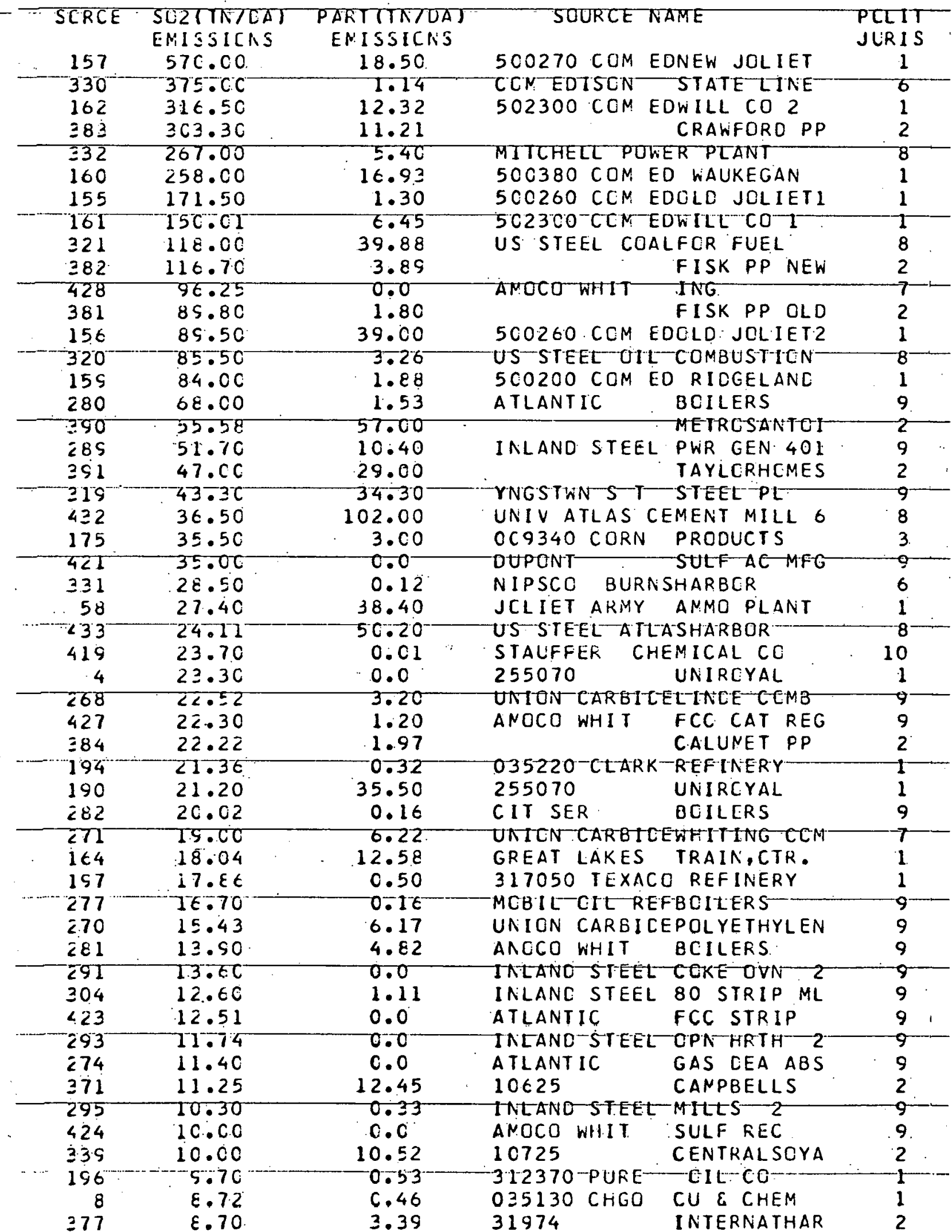




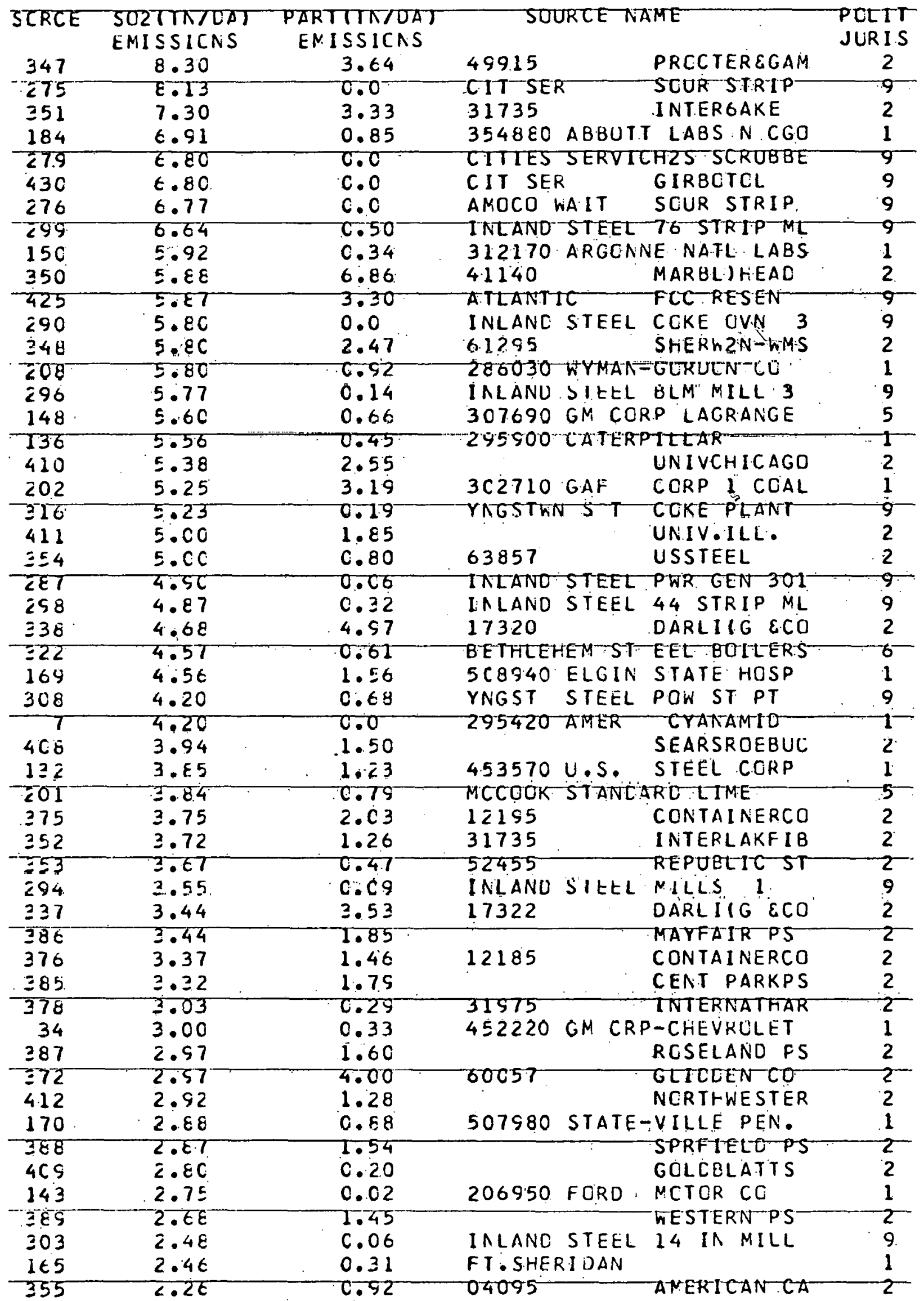




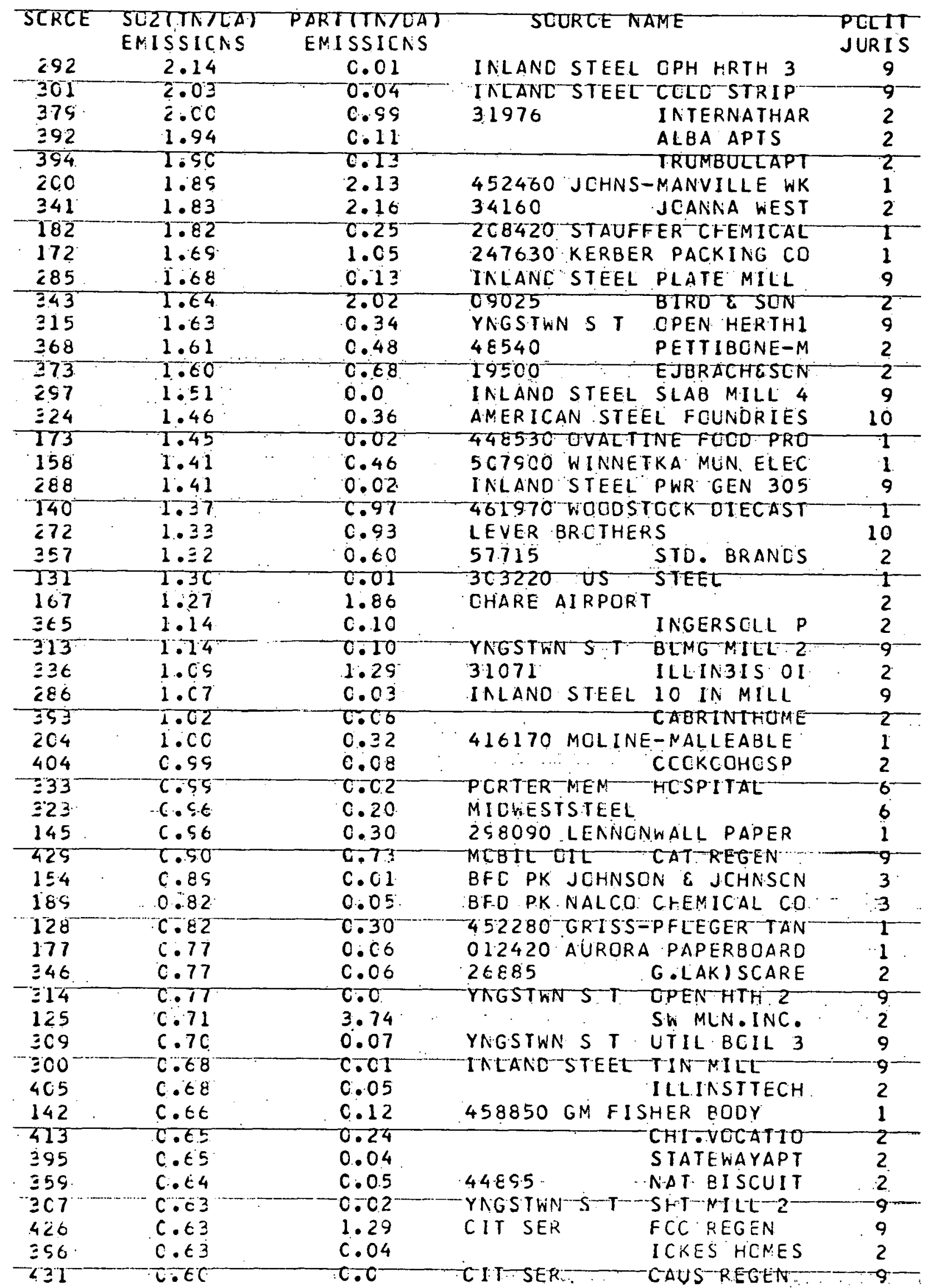




\begin{tabular}{|c|c|c|c|c|}
\hline SCRCE & $\begin{array}{l}\text { SCLTINTLAT } \\
\text { EMISSICNS } \\
\text { C.EC }\end{array}$ & $\begin{array}{c}\text { PARTTTITOAT } \\
\text { EMISSICNS } \\
0.03\end{array}$ & 026940 STANCARC SCREW CO & $\begin{array}{c}\text { POLIT } \\
\text { JURIS } \\
1\end{array}$ \\
\hline $\begin{array}{l}406 \\
\equiv 50 \\
207\end{array}$ & $\begin{array}{l}C .55 \\
C .58 \\
C .56\end{array}$ & $\begin{array}{l}0.50 \\
0.04 \\
0.05\end{array}$ & $\begin{array}{ll} & \text { MERCH MART } \\
66650 & \text { WESTERN FEL } \\
43060 \mathrm{C} \text { TELE } & \text { TYPE CORP }\end{array}$ & $\begin{array}{l}2 \\
2 \\
1\end{array}$ \\
\hline $\begin{array}{l}168 \\
328 \\
342\end{array}$ & $\begin{array}{l}C .55 \\
C .55 \\
C .55\end{array}$ & $\begin{array}{l}0.38 \\
0.21 \\
0.30\end{array}$ & $\begin{array}{ll}\text { O37710 RLSST } & \text { S SCNS } \\
\text { SCREW BOLT } & \text { CCRP CF AM } \\
53281 & \text { RCCK-OLA }\end{array}$ & $\begin{array}{l}1 \\
8 \\
2\end{array}$ \\
\hline 284 & $\begin{array}{l}C .54 \\
C .53\end{array}$ & $\begin{array}{l}0.08 \\
0.04\end{array}$ & $\begin{array}{l}\text { TNLAND STEEL PWR GEN } 211 \\
65190 \\
\text { WFHALLPRNTG }\end{array}$ & 2 \\
\hline $\begin{array}{l}363 \\
126 \\
124 \\
345\end{array}$ & $\begin{array}{l}0.53 \\
0.5 .2 \\
C .48 \\
C .48\end{array}$ & $\begin{array}{l}C .15 \\
2 \cdot 76 \\
2.52 \\
C .03\end{array}$ & $\begin{array}{l}\text { HCRWEEN LTH } \\
\text { CALCNETMINC } \\
\text { MEDILLM.INC } \\
\text { CUNEC PRESS }\end{array}$ & $\begin{array}{l}2 \\
2 \\
2 \\
2\end{array}$ \\
\hline $\begin{array}{l}297 \\
212 \\
273\end{array}$ & $\begin{array}{l}0.47 \\
0.46 \\
0.45\end{array}$ & $\begin{array}{l}0.22 \\
0.06 \\
0.0\end{array}$ & $\begin{array}{ll}\text { YNGSTWN S I } & \text { BLENTEORTH A } \\
\text { MCBIL CIL } & \text { FLARE }\end{array}$ & $\begin{array}{l}2 \\
3 \\
9\end{array}$ \\
\hline $\begin{array}{l}305 \\
325 \\
191\end{array}$ & $\begin{array}{l}0.45 \\
0.44 \\
0.44\end{array}$ & $\begin{array}{l}c . c 5 \\
0.02 \\
c .07\end{array}$ & $\begin{array}{l}\text { YNGSTWN ST OUA TN STRTF } \\
\text { UN TANK CAR } \\
\text { BFD PK UNICN CARBIDE }\end{array}$ & $\begin{array}{r}9 \\
10 \\
3\end{array}$ \\
\hline $\begin{array}{l}212 \\
185 \\
1 \in 6\end{array}$ & $\begin{array}{l}0.43 \\
0.43 \\
0.43\end{array}$ & $\begin{array}{l}0.40 \\
0.04 \\
0.58\end{array}$ & $\begin{array}{l}\text { BFD PK CCNTAL CANCO } \\
429.940 \text { SEARLE \& CC } \\
\text { FEDERAL BLOG }\end{array}$ & $\begin{array}{l}-3 \\
1 \\
2\end{array}$ \\
\hline $\begin{array}{l}266 \\
335 \\
210\end{array}$ & $\begin{array}{l}C .43 \\
C .43 \\
c .42\end{array}$ & $\begin{array}{l}0.03 \\
0.03 \\
0.03\end{array}$ & $\begin{array}{ll}52705 & \text { RHEEN MFE } \\
25140 & \text { GNL RENEERI } \\
\text { YNGSTKN S T SMISS PIPE }\end{array}$ & $\begin{array}{l}2 \\
2 \\
9\end{array}$ \\
\hline $\begin{array}{l}258 \\
199 \\
149\end{array}$ & $\begin{array}{l}C .38 \\
C .38 \\
0.37\end{array}$ & $\begin{array}{l}0.30 \\
0.02 \\
0.03\end{array}$ & $\begin{array}{l}\text { LATHFOPHOME } \\
206350 \text { CERTAIN-TEED } \\
285790 \text { SINCLAIR RESEARCH }\end{array}$ & $\begin{array}{l}2 \\
1 \\
1\end{array}$ \\
\hline $\begin{array}{l}283 \\
152 \\
198\end{array}$ & $\begin{array}{l}0.36 \\
0.35 \\
0.35\end{array}$ & $\begin{array}{l}0.0 \\
0.02 \\
0.02\end{array}$ & $\begin{array}{l}\text { TNLANL STEEL BLKSMTH SHP } \\
\text { BFD PK MILES LABS } \\
505160 \text { TRUMBUL ASPHALT }\end{array}$ & 3 \\
\hline $\begin{array}{l}181 \\
133 \\
213\end{array}$ & $\begin{array}{l}0.35 \\
0.35 \\
0.34\end{array}$ & $\begin{array}{l}0.05 \\
0.04 \\
0.03\end{array}$ & $\begin{array}{l}327700 \text { SMITH CHEMTCAL WK } \\
452490 \text { JCHNSON MOTORS } \\
53440 \text { STEVART }\end{array}$ & $\begin{array}{l}1 \\
1 \\
2\end{array}$ \\
\hline $\begin{array}{l}130 \\
\equiv 11 \\
267\end{array}$ & $\begin{array}{l}0.33 \\
0.33 \\
0.22\end{array}$ & $\begin{array}{l}0.35 \\
0.04 \\
c .36\end{array}$ & $\begin{array}{l}355240 \text { FANSTEEL MTL CORP } \\
\text { YAGSTN } \$ \text { T MEP MILL } \\
28460 \\
\text { HANCY BLTTO }\end{array}$ & $\begin{array}{l}1 \\
9 \\
2\end{array}$ \\
\hline $\begin{array}{l}205 \\
217 \\
402\end{array}$ & $\begin{array}{l}0.22 \\
0.21 \\
0.21\end{array}$ & $\begin{array}{l}0.05 \\
0.09 \\
0.12\end{array}$ & $\begin{array}{l}206620 \text { COLUMBTA TCOL STL } \\
\text { YAGSTWN S T SHEET MILL2 } \\
\text { OLDTCWNAPTS }\end{array}$ & 2 \\
\hline $\begin{array}{l}463 \\
261 \\
264\end{array}$ & $\begin{array}{l}0.21 \\
0.21 \\
0.31\end{array}$ & $\begin{array}{l}0.04 \\
0.22 \\
0.37\end{array}$ & $\begin{array}{l}\text { SANCEUREVIT } \\
\text { ARVEY CORP. } \\
\text { CHI.RAKHICE }\end{array}$ & $\begin{array}{l}2 \\
2 \\
2\end{array}$ \\
\hline $\begin{array}{l}362 \\
454 \\
183\end{array}$ & $\begin{array}{l}C \cdot 3 c \\
C .30 \\
C .30\end{array}$ & $\begin{array}{l}0.58 \\
0.0 \\
0.21\end{array}$ & $\begin{array}{l}59100 \text { SUPER TANNI } \\
\text { US LEAD REFINERY } \\
454380 \text { AMER PCTASH CORP }\end{array}$ & 2 \\
\hline $\begin{array}{l}214 \\
129 \\
260\end{array}$ & $\begin{array}{l}T .25 \\
C .25 \\
C .25\end{array}$ & $\begin{array}{l}0.02 \\
0.03 \\
0.04\end{array}$ & $\begin{array}{l}02750 \text { BELOEN MFG } \\
245710 \text { CHICAGO RAWHICE } \\
60313 . \\
\text { GORDEN EAKI }\end{array}$ & $\begin{array}{l}-2 \\
1 \\
2\end{array}$ \\
\hline $\begin{array}{l}374 \\
255\end{array}$ & $\begin{array}{l}C \cdot 25 \\
C \cdot 28\end{array}$ & $\begin{array}{l}0.02 \\
0.02\end{array}$ & $\begin{array}{l}\text { WMKRIGLEYCO } \\
\text { RCCKWELLAPT }\end{array}$ & 2 \\
\hline ¿15 & & & CCRN PRCCUC & 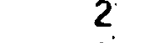 \\
\hline
\end{tabular}




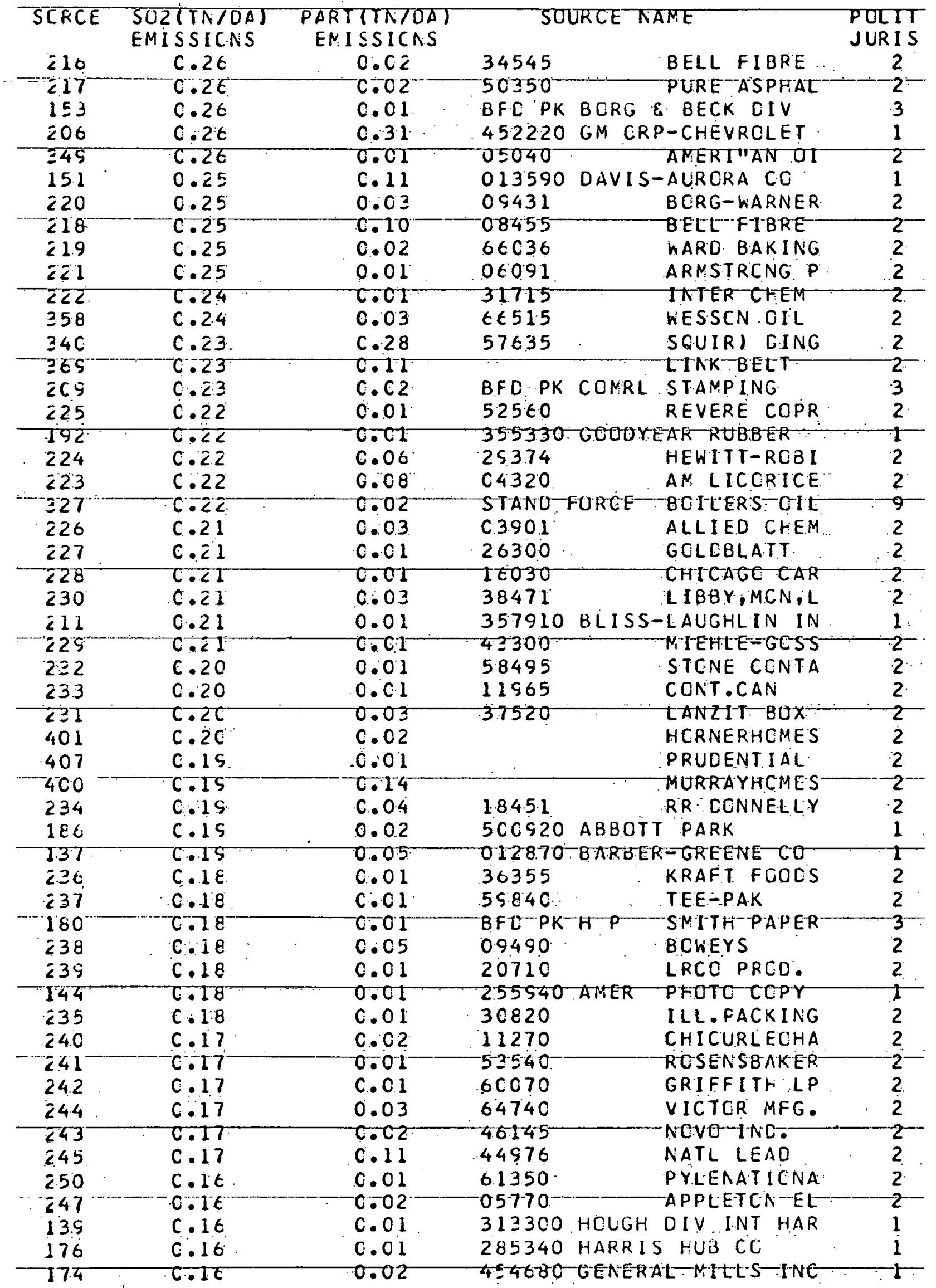




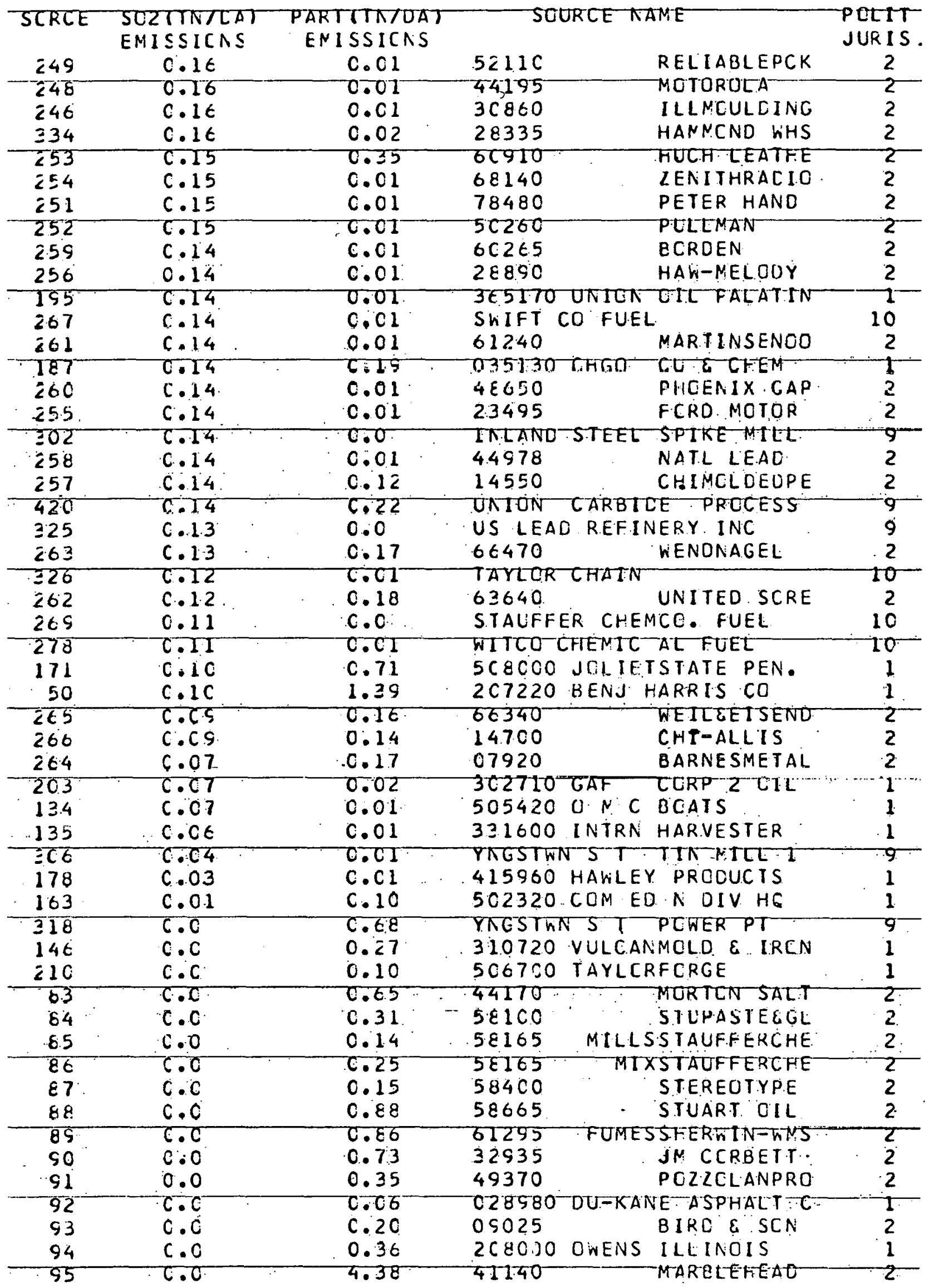




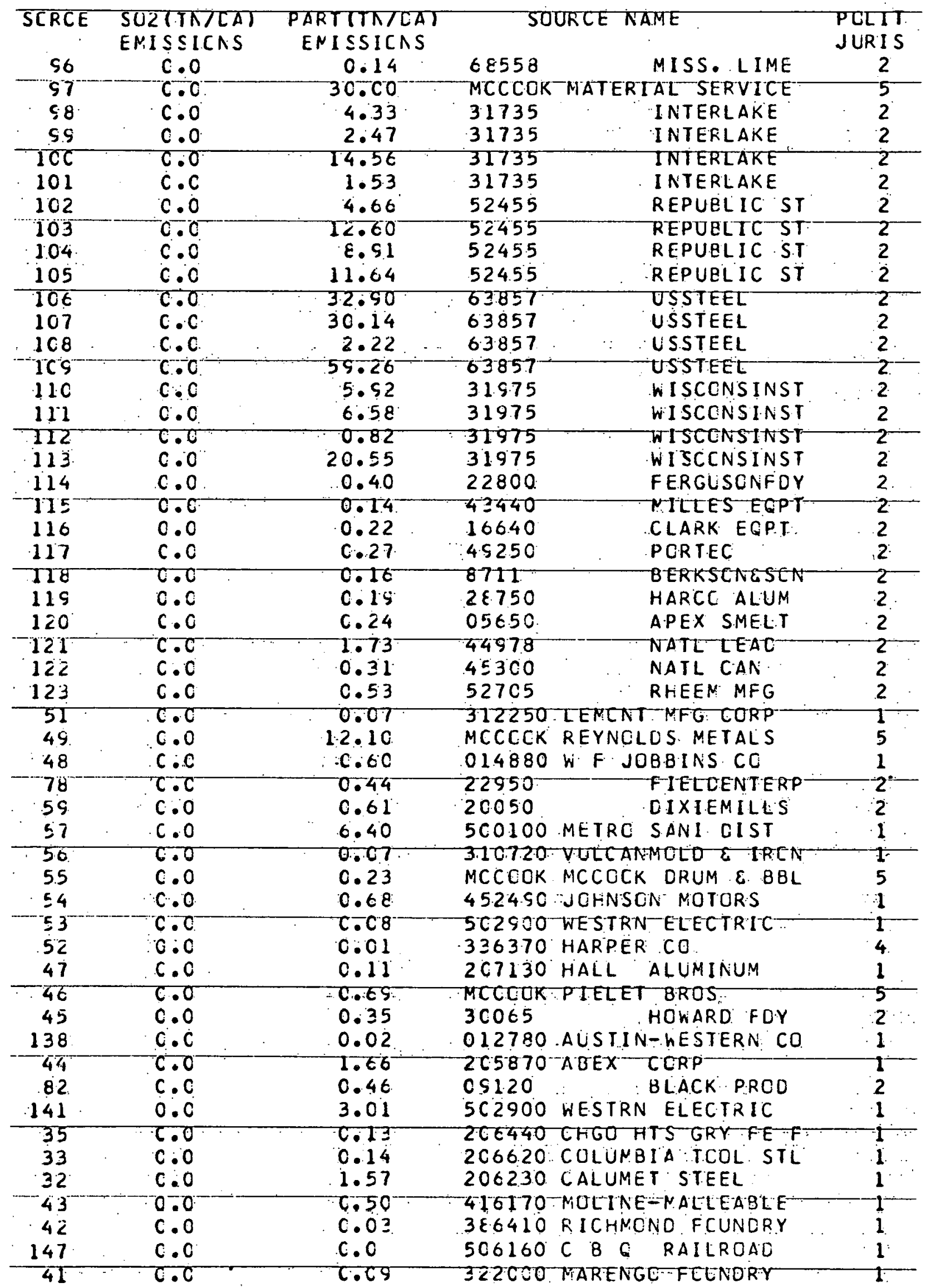




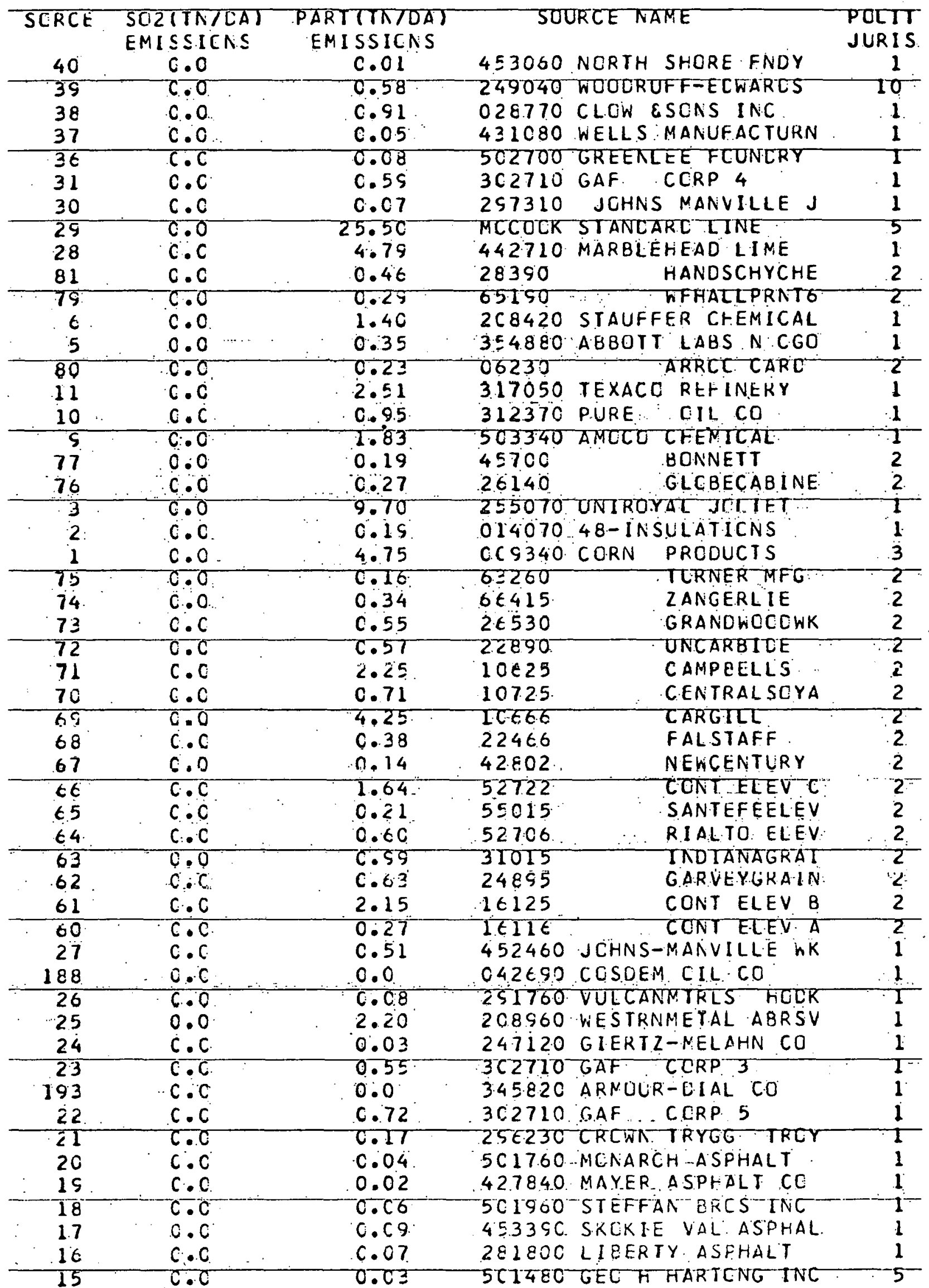




\begin{tabular}{|c|c|c|c|c|}
\hline SCRCE & $\begin{array}{l}\text { SOLCTNTEAT } \\
\text { EMISSICNS } \\
\text { C. } 0\end{array}$ & $\begin{array}{l}\text { PARTITNICAT: } \\
\text { ENISSICAS } \\
\text { C.81 }\end{array}$ & 312160 CRCWN-TRYGG CORP & $\begin{array}{l}\text { POLII } \\
\text { JURIS } \\
1\end{array}$ \\
\hline $\begin{array}{r}13 \\
12 \\
439\end{array}$ & $\begin{array}{l}0.0 \\
0.0 \\
0.0\end{array}$ & $\begin{array}{l}0.06 \\
0.1 .9 \\
1.00\end{array}$ & $\begin{array}{l}5 C 2040 \text { CRCWN TRYGG JOLET } \\
442.620 \text { GALLAGHER ASPHALT } \\
\text { IALAND STEEL SINTERING D }\end{array}$ & $\begin{array}{l}1 \\
1 \\
9\end{array}$ \\
\hline 422 & $C \cdot C$ & 0.25 & ONTCIN CAREIDE KRI IING & 7 \\
\hline $\begin{array}{l}446 \\
370\end{array}$ & $\begin{array}{l}c . c \\
c .0\end{array}$ & $\begin{array}{l}0.66 \\
0.01\end{array}$ & $\begin{array}{ll}\text { US STEEL } & \text { CEKE PLANT } \\
& \text { WEST.ELECTR }\end{array}$ & $\begin{array}{l}9 \\
2\end{array}$ \\
\hline $\begin{array}{l}453 \\
442 \\
436\end{array}$ & $\begin{array}{l}0.0 \\
0.0 \\
0.0\end{array}$ & $\begin{array}{l}0.14 \\
0.08 \\
1.15\end{array}$ & $\begin{array}{l}\text { ANER STEEL FCUNCRY IHW } \\
\text { YNGST S T SCARFINE } 2 \\
\text { YNGSTN S T SCAKFING }\end{array}$ & $\begin{array}{l}9 \\
9 \\
9\end{array}$ \\
\hline $\begin{array}{l}436 \\
452 \\
417 \\
3.8 C\end{array}$ & $\begin{array}{l}C .0 \\
C .0 \\
C .0 \\
0.0\end{array}$ & $\begin{array}{l}1.15 \\
0.20 \\
0.71 \\
0.0\end{array}$ & $\begin{array}{l}\text { YNGSTN S I SCARFING I } \\
\text { ANER: STEEL FCUNDRTES IHW } \\
\text { MIDWAYAI RPORT JET PLANES } \\
\text { NORTHWESTPP }\end{array}$ & $\begin{array}{l}y \\
9 \\
2 \\
2\end{array}$ \\
\hline $\begin{array}{l}438 \\
437 \\
447\end{array}$ & $\begin{array}{l}C \cdot 0 \\
C .0 \\
C .0\end{array}$ & $\begin{array}{l}1 \% 13 \\
C .71 \\
C .40\end{array}$ & $\begin{array}{l}\text { INLANC STEEL BCFS } \\
\text { INLAND STEEL BLAST FURN } \\
\text { IALANC STEEL OP HE PL } 3\end{array}$ & $\begin{array}{l}9 \\
9 \\
9\end{array}$ \\
\hline $\begin{array}{l}445 \\
4.58 \\
455\end{array}$ & $\begin{array}{l}C . C \\
C .0 \\
C . C\end{array}$ & $\begin{array}{l}0.80 \\
0.98 \\
0.90\end{array}$ & $\begin{array}{l}\text { THLANO STEEL SINTERTNG } \\
\text { STANC FORGE PUSHER FCE } \\
\text { US RED } \\
\text { CHLCR. }\end{array}$ & $\begin{array}{l}9 \\
9 \\
9\end{array}$ \\
\hline $\begin{array}{l}449 \\
444 \\
415\end{array}$ & $\begin{array}{l}0.0 \\
0.0 \\
0.0\end{array}$ & $\begin{array}{l}64.40 \\
1.23 \\
0.44\end{array}$ & $\begin{array}{l}\text { US STEEL SINTER INE PLANT } \\
\text { US STEEL BOF. } \\
\text { OHARE AIRFORTTURBCPROPS }\end{array}$ & $\begin{array}{l}8 \\
8 \\
2\end{array}$ \\
\hline $\begin{array}{l}448 \\
41.4 \\
4.51\end{array}$ & $\begin{array}{l}C \cdot C \\
C: C \\
C \cdot C\end{array}$ & $\begin{array}{r}1.54 \\
19.70 \\
C .54\end{array}$ & $\begin{array}{l}\text { TNLAND STEEL SCARANG } \\
\text { OHARE AIRFORT JET PLANES } \\
\text { KEEA FNDRY GRAY IRCN }\end{array}$ & $\begin{array}{l}9 \\
2 \\
7\end{array}$ \\
\hline $\begin{array}{l}435 \\
418 \\
450\end{array}$ & $\begin{array}{l}C \cdot 0 \\
C \cdot 0 \\
C \cdot 0\end{array}$ & $\begin{array}{r}85.50 \\
1.07 \\
0.76\end{array}$ & $\begin{array}{l}\text { US STEEL CPENHEARTHS } \\
\text { MIOWAYAIRFORTPISTCNS } \\
\text { HARBISCN WN KER REFRACT }\end{array}$ & $\begin{array}{r}8 \\
2 \\
10\end{array}$ \\
\hline $\begin{array}{l}441 \\
459 \\
440\end{array}$ & $\begin{array}{l}0.0 \\
0.0 \\
C .0\end{array}$ & $\begin{array}{r}20.60 \\
0.80 \\
11.30\end{array}$ & $\begin{array}{l}\text { INLANC STEEL COP H PL } \\
\text { STAND FORCE RCIARY FCE } \\
\text { INLAND STEEL CCKIAG PL }\end{array}$ & $\begin{array}{l}9 \\
9 \\
9\end{array}$ \\
\hline $\begin{array}{l}434 \\
416 \\
457\end{array}$ & $\begin{array}{l}C .0 \\
0.0 \\
0.0\end{array}$ & $\begin{array}{l}1.19 \\
0.37 \\
0.33\end{array}$ & $\begin{array}{l}\text { YNGSTRN ST SINTERING } \\
\text { OHARE AIRPORTPISTCNS } \\
\text { AMER SMELTINGANO REFIN }\end{array}$ & $\begin{array}{l}9 \\
2 \\
7\end{array}$ \\
\hline $\begin{array}{l}443 \\
456\end{array}$ & $\begin{array}{l}0 . C \\
C .0\end{array}$ & $\begin{aligned} 10.40 \\
c .12\end{aligned}$ & $\begin{array}{l}\text { US STEEL BLAST FURNACE I- } \\
\text { US REC SECCA AL }\end{array}$ & $\begin{array}{l}8: \\
9\end{array}$ \\
\hline
\end{tabular}


$1 /$ CHIP3 JOB (F12844, 45,9.1.). 'MAFY SNIDER', MSGLEVEL $=1$.

CROKE E $12383 \quad 05782-00190$

I) REGION $=3$ BEK . CLASS $=B$

/ $5 E$ TUP DDNAME = DUM1, DEVICE $=2314$, ID $=$ DISK59

/ FORMAT FR, DDNAME $=$ FTEGFQB1, COP.IES $=5$

I/STEP. EXEC SORTD

/ /SORTIN DD DSN=5TLSORC9, UNIT =DISK, DISP = (OLD, KEEP), VOL =SER=DISKSS

//SORTOUT DD DSN=INSORC 1Q. UNIT =DISK: DISP = COLD, KEEP I, VOL =SER=DISKSS,

1) SPACE $=(T R K,(16,18)), D C B=(R E C F M=F B, L R E C L=250 . B L K S I Z E=7808$.

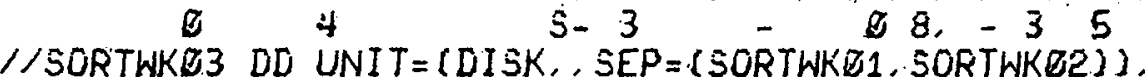

I) SPACE $=(T R K ;(2 Q Q)$, , CONTIE $)$.

/ SORTWKE4 DD UNIT = (DISK, SEP = (SORTWKE1, SORTWKEE, SORTWKE3) ),

i) SPACE $=(T R K,(2 Q Q)$, , CONTIG)

I/SYSIN DD

SORT FIELDS $=(25,6,8.8, F I, D) ; S I Z E=E 1 B E Q$ END

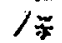

I/STFP3 EXEC FTECLG

I/FTE.SYSIN DD

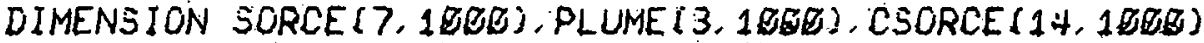

DIMENSION SORCNO (1EOO). SRCNM $(8,1$ 1EQE)

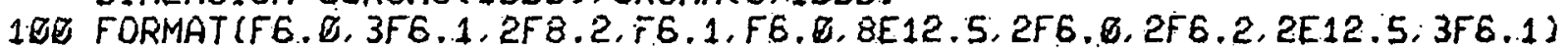
$I=\Xi$

$1 I=I+1$

READ ( 10,108, END =2) SORCNO (1), (SORCE $(J, I), J=1,7),(C S O R C E(J, I)$,

$1 \mathrm{~J}=1,14$ ), (PLUME (J, I) . J $=1,3$.)

IF (SORCE (7. I) EQ.9999.8) I =I-1

GO TO 1

2 CONTINUE

NSORCE $=I-1$

$\operatorname{READ}(11,12, E N D=110)$ ( (SRCNM $(I, J), I=1,82, J=1$, NSORCE)

12 FORMAT ( $3 A 4$, A 1 )

116 $L I N E=\square$

WRITE $(6,1006)$

DO $1100 . I=1$. NSORCE

$\angle I N E=L I N E+1$

IF ILINE.LT.53:30 TO 1101

WRITE $(6,100 Q)$

LINE $\approx$ B

1181 CONTINUE

SORCE $(1, I)=$ SORCE $(1, I) \div .6241$

SORCE (2, I) SORCE $(2 . I)+6241$

ISORCE $=$ SORCNO $[$ I.

WRITE (6, 1061) SORCNO (I), SORCE (4, I), SORCE (5, I), CSORCE (10. I).

1 SORCE (1, I), SORCE (2, I i, (SRCNM ( J, ISORCE) $, J=1,8)$

1100 CONTINUE

1GEO FORMAT 1 H 1 . 5HSORCE: $3 \times .16 \mathrm{H}$ SO2 EMISSION

1 21HPART EMISSION POLIT, 5X, 1HX, 8X, 1HY,

$2 / 16 X, 16 H$ RATE TN/DAY , 2BH RATE TN/DAY JURIS,

$35 X, 18 H$ MTLES $/ 3$

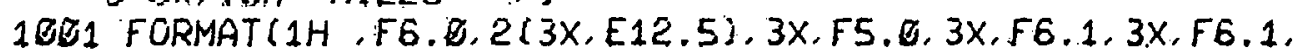

$15 X, 2(3 A 4, A 1))$

STOP

END

$/ 7$

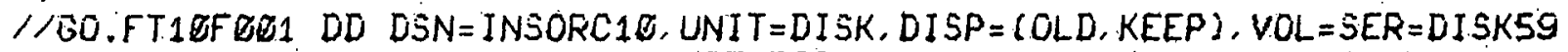

//GO.FT11FEE1 DD DSN=STLNAME, UNIT $=D I S K . D I S P=(O L D, K E E P), V O L=S E R=D I S K 59$

/ 
APPENDIX B

ASSM Program

1. ASSM Program Listing and Subroutine Description (see Fig. B-1)

\section{LIST OF SUBROUTINES}

Subroutine

Description

Page

BLOCK DATA Initializes variables in labeled common 102

CULPLT Generates culpability lists 103

IOCONV Converts machine representation to EBCDIC 106

LINSRT Sorts source contributions for a given receptor into descending order

MAIN Inputs all data; adjusts calculation parameters; drives basic subroutines

POLUT Computes ground-level concentration and source contributions for selected receptors; outputs receptor concentration data

SELECT Selects receptors for output in the culpability list

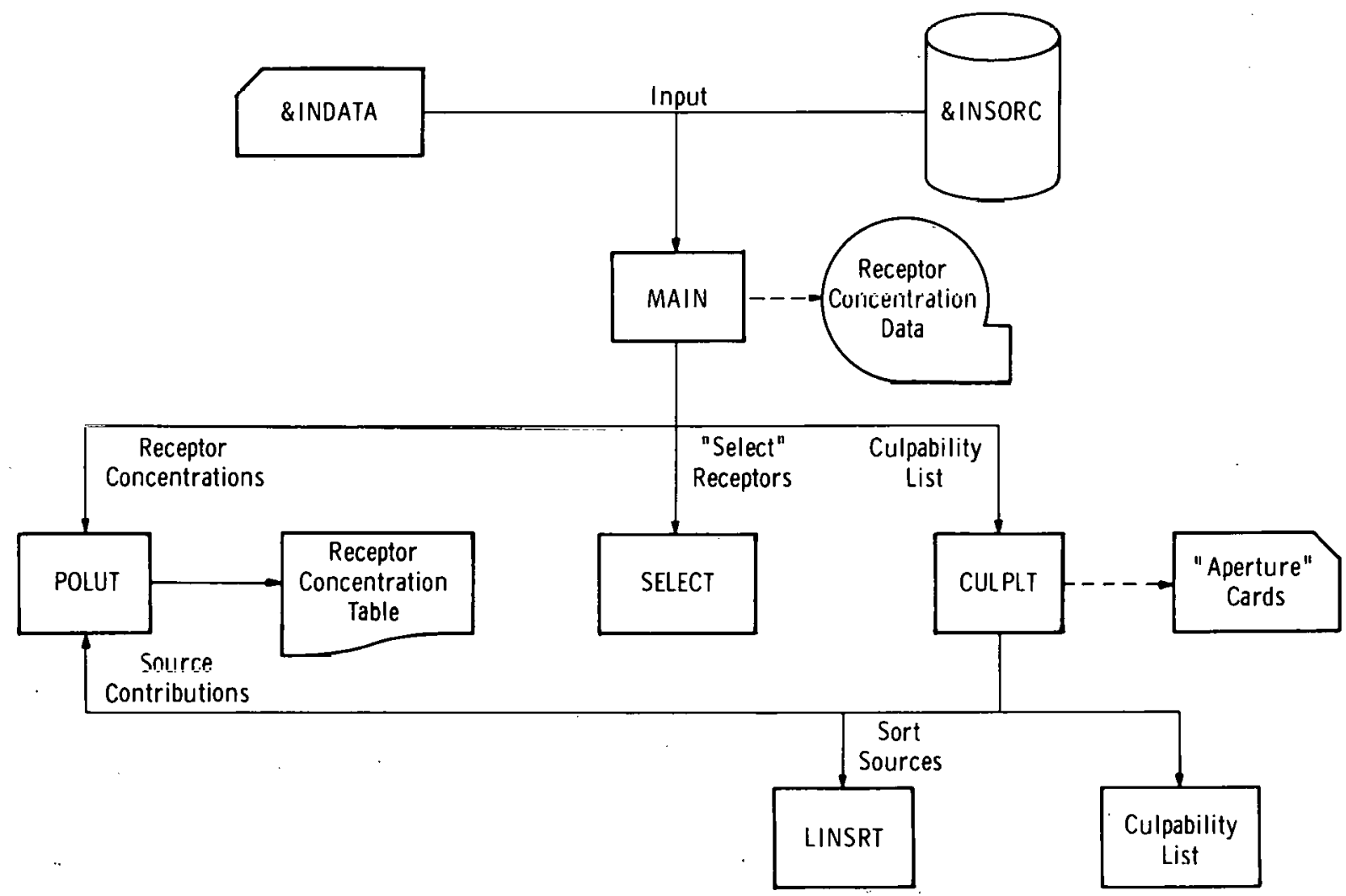

Fig. B-1. ASSM Program Structure 
a. BLOCK DATA

Description: Initializes variables in labeled common

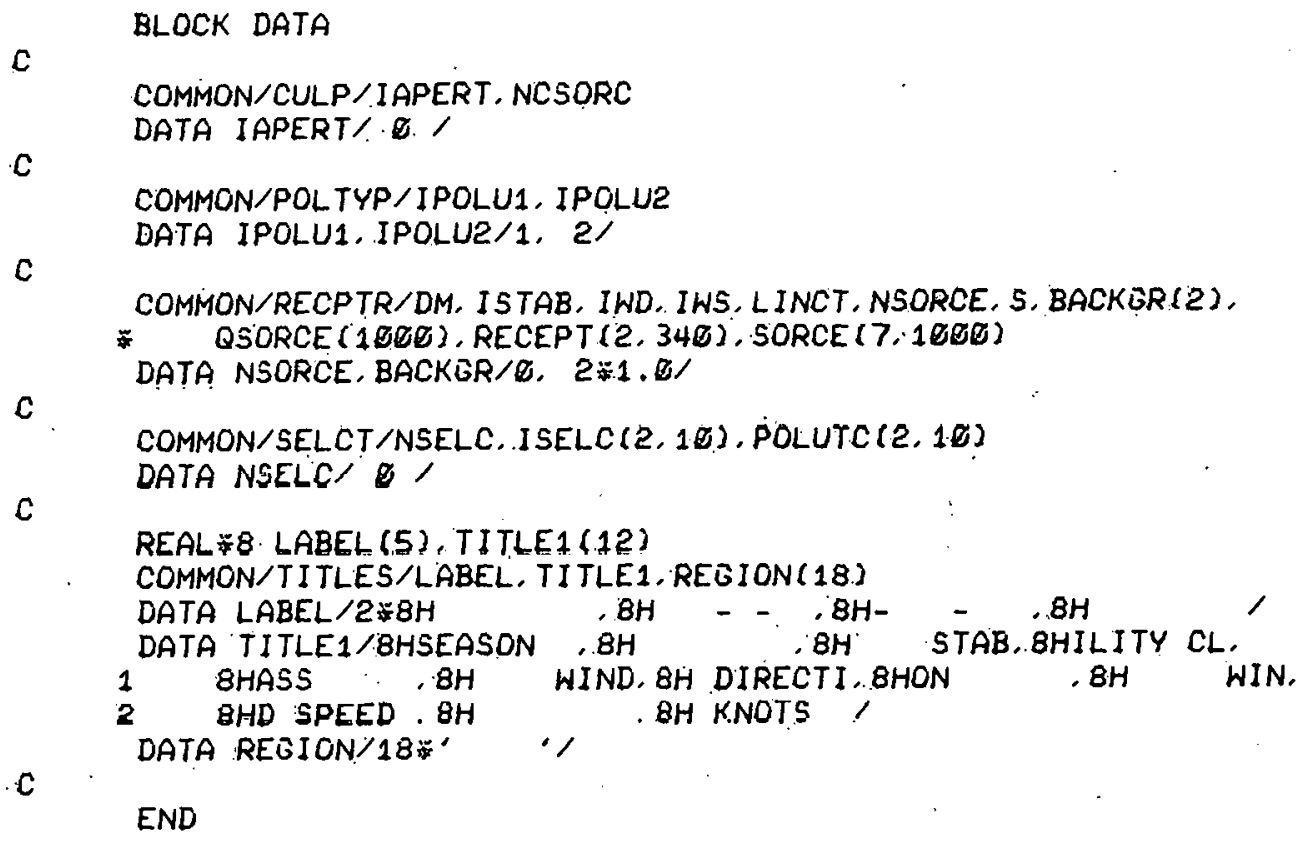

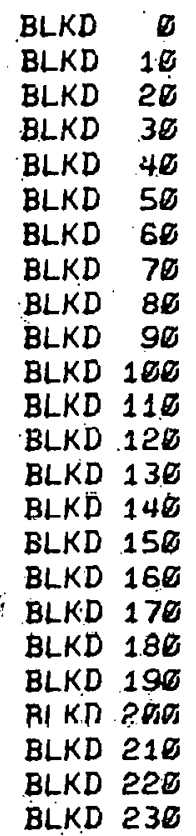


b. Subroutine CULPLT

Description:

Parameters: NHIGH

MSRC

Qutput:
This subroutine generates the culpability list indicating the highest contributors to each receptor in a "selected" list of receptors. It calls POLUT to calculate the contributions from all sources for a given receptor and then calls LINSRT to order these source contributions.

Number of "selected" receptors to appear in the culpability list $(\leq 10)$. Number of sources to appear in the culpability list $(\leq 20)$. Culpability list containing the highest source contributions to each receptor for a given set of receptors. Under each selected receptor, sources and their effective stack hei.ghts are listed in descending order of absolute and percent pollutant contribution. 
SUBROUTINE CULPLT (NHIGH, MSRC) CULP E

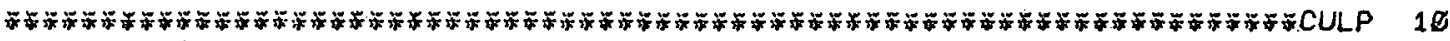

SUEROUTINE GENERATES A CULPABILITY LIST OF THE (MSRC) HIGHEST CULP 20

SOURCES OF POLLUTION FOR EACH.RECEPTOR IN A "SELECTED" SET OF CULP' 30

(NHIGH) RECEPTORS. FOR EACH SOURCE, THE SOURCE ID. THE (ACTUAL \& CULP $4 E$

PERCENTAGEJ CONTRIBUTION FROM THIS SOURCE TO THE RECEPTOR. AND CULP 50

THE EFFECTIVE STACK HEIGHT OF THE SOURCE IS LISTED.

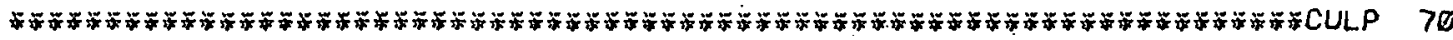

INTEGER SRCID, SORID. $\quad$ CULP 80

REAL $: 8$ LABEL (5). MES1(4), MES2(2), TITLE1(12), DASHES(3), RECPTR

COMMON/CULP/IAPERT. NCSORC

COMMON/POLTYP/IPOLU1, IPOLUR

COMMON/SELCT/NSELC. ISELC $(2,10)$, POLUTC $(2,10)$

COMMON/SRCS/IPOLUT, NPTSRC. HEFF (1OEO), SORCON(5EO), SORID(5EO)

COMMON/TITLES/LABEL. TITLE1, REGION(18)

DIMENSION SRCCON $(10,2 \theta), \operatorname{SRCID}(1 \theta, 2 \theta), \operatorname{SRCHE}(10,2 \theta)$, INDEX (5EO).

* TPOLUT.(10), SPER (10), TSPER (10), TSCON(10)

DIMENSION MPOLU(2), FLAG (1E)

c

DATA ASTER, BLANK/1Hï, $1 \mathrm{H} /$

DATA DASHES, RECPTR/3W8H-....., 8HRECEPTOR/

DATA MES1/8HSO2.
DATA MES2/8HHIGHEST . 8HSELECTED/

DATA. MPOLU/4HSO2, 4 HPRT $/$

$c$

LOOP ON POLUTANT TYPES

DO $2 E$ IPOLUT = IPOLU1. IPOLU2

c

LOOP ON "SELECTED" RECEPTORS

I $1=2$ IPOLUT -1

$I 2=I 1+1$

DO 3 NRECP $=1$, NHIGH

C

C

INITIALIZE SUMMARY VARIABLES

TPOLUT (NRECP) $=$ POLUTC (IPOLUT, NRECP)

$T S C O N(N R E C P)=E . E$

TSPER (NRECP) $=\varnothing . \theta$

IRECEP $=$ ISELC (IPOLUT, NRECP)

C

CALCULATE SOURCE CONTRIBUTIONS FOR THIS RECEPTOR

NPTSRC: $=0$

CALL POLUTIIRECEP, . TRUE.;

IF (NPTSRC .EQ. Q) GO TO 11

C

SORT SORCE CONCENTRATIONS INTO DËEREASINÜ ORDER

DO 1 I $=1$. NPTSRC

INDEX(I) $=I$

C

1 CONTINUE

CALL LINSRT (NPTSRC, SORCON. INDEX)

NPISKL = MINE (NPTSRC, MSRC)

C REORDER CONCENTRATIONS

DO $2 I=1$. NPTSRC

IPTSRC $=$ INDEX (I)

SRCCON(NRECP. I) = SORCON (IPTSRC)

SRCID(NRECP, I) = SORID(IPTSRC)

SRR.HF.(NRFSP. I ) $=$ HEFF (IPT.SRC)

c

2 CONTINUE

IF (NPTSRC .EQ. MSRC) GO TO 3

$11 M 1=N P T S R C+1$

LO. $12 \mathrm{I}=$ M1.MSRC

$S R C C O N(N R E C P, I)=D . O$

SRCID (NRECP, I) $=\theta$

SRCHE (NRECP. I ) := $=0 . E$

C

12 CONTINUE

3 CONTINUE

C

$N 1=1$
CULP 106

CULP 110

CULP 120

CULP 130

CULP 140

CULP 150

CULP 168

CULP 170

CULP 180

CULP 19E

LULP EUE

CULP 210

CULP 220

CULP 23E

CULP 240

CULP 250

CULP 260

LULP ¿ं7ש

CULP 280

CULP 290

CULP 300

CULP 31E

CULP 320

CULP 330

CULP 340

CULP 350

CULP 360

CULP 370

CULP 380

CULP 390

CULP 4EE

LULP 421

CULP 420

CULP 430

CULP +40

CULP 450

CULP 46E

CULP 470

CULP 480

CULP 498

CULP $50 E$

CUIP 510

CULP 520

CULP 530

CULP 540

CULP 550

CULP 560

CULP 570

CULP 580

CULP 590

CULP 6ED

CULP 610

CULP 620

CULP. 630

CULP 640

CULP 650

CULP 660

CULP 670 


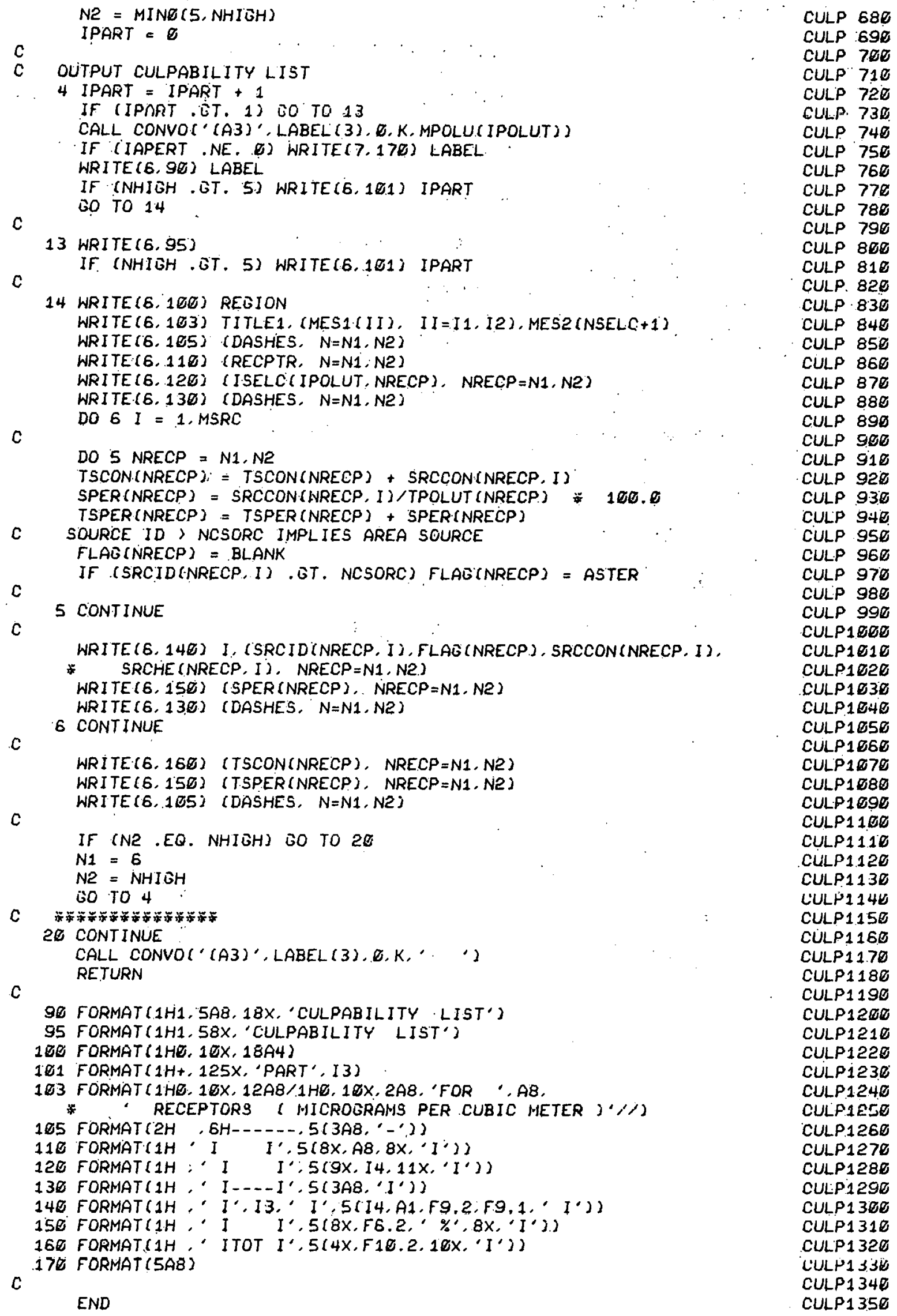


c. Subroutine IOCONV

Description:

Parameters : FMT

ARRAY

ARRINU

WIDTH

$\mathrm{X}$
This subroutine is a FORTRAN-callable

OS/360 assembly language routine which converts from internal machine representation to EBCDIC. It also has the capability to "insert (EBCDIC) characters" into a "string".

The character string used as the format specification.

The output EBCDIC representation.

The byte offset from ARRAY to the starting byle.

The numbers of bytes used in ARRAY.

Variable(s) to be used. 


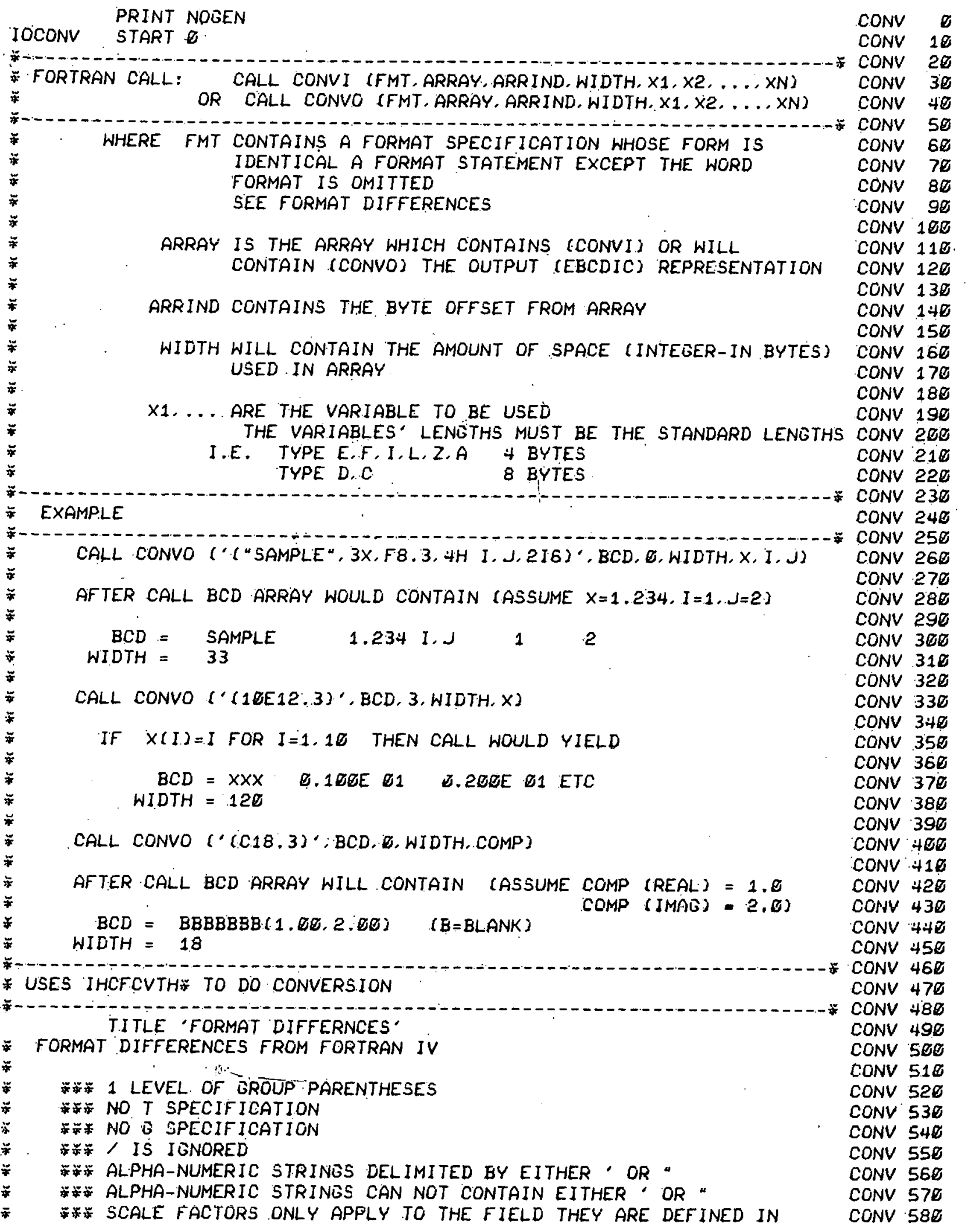




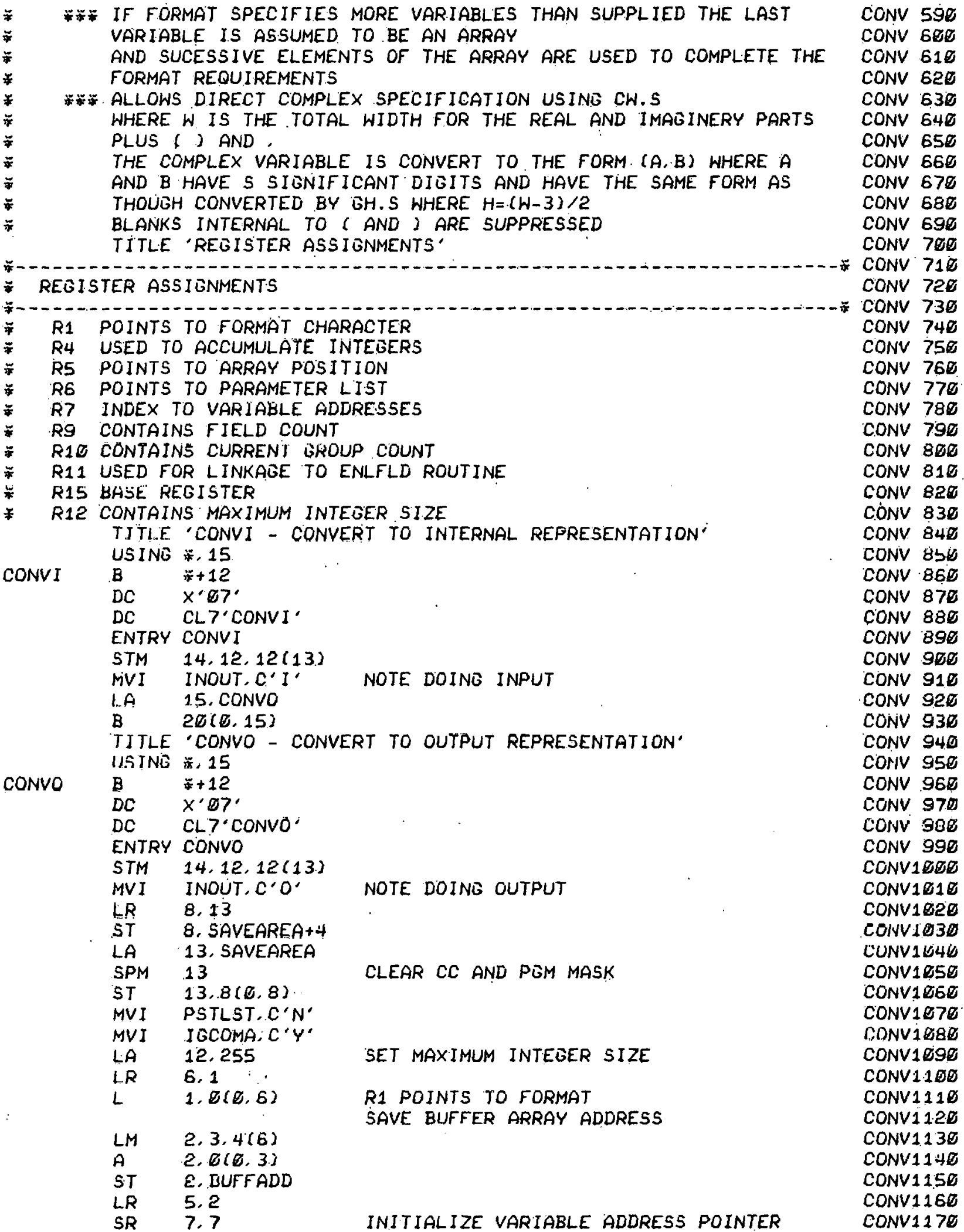




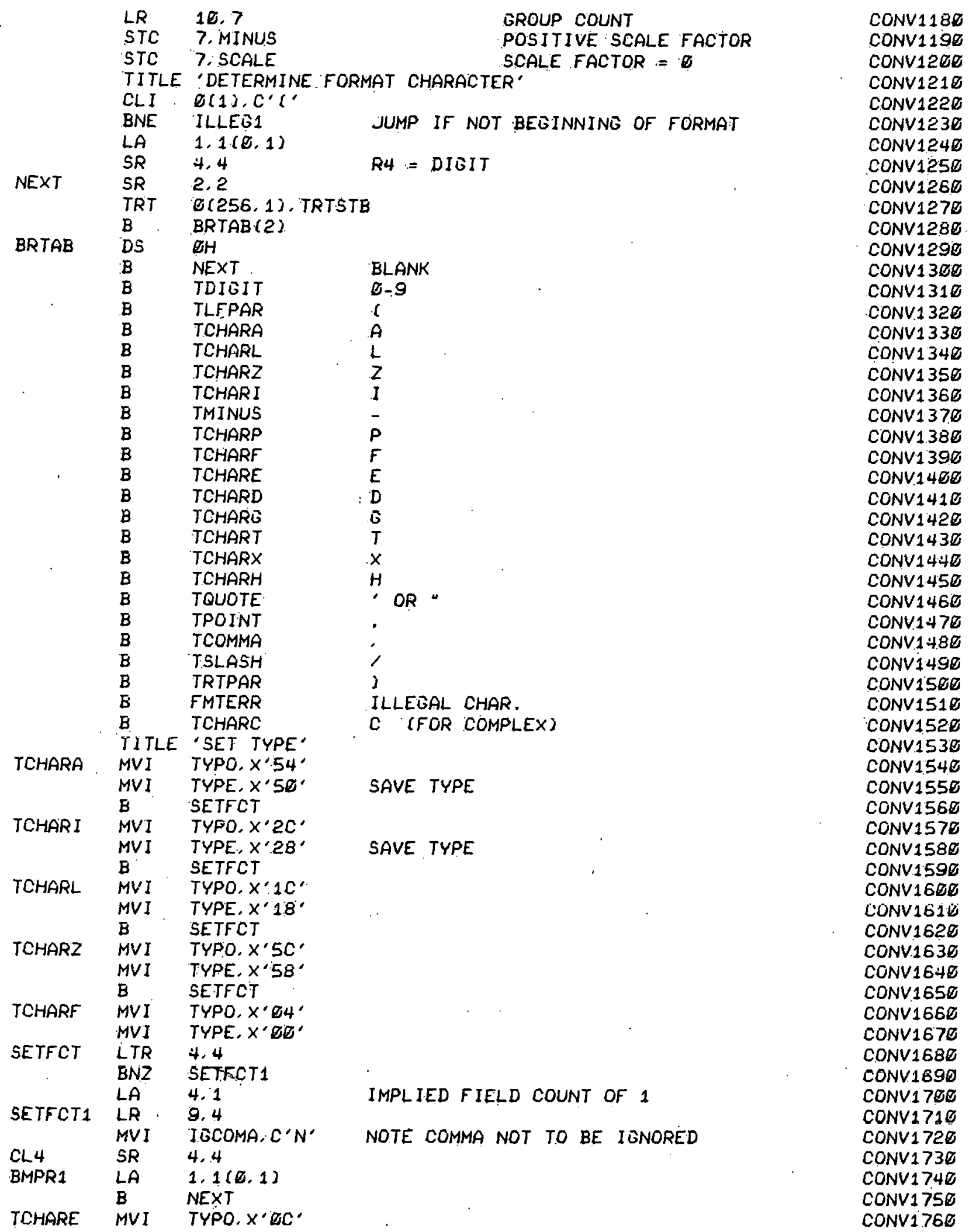




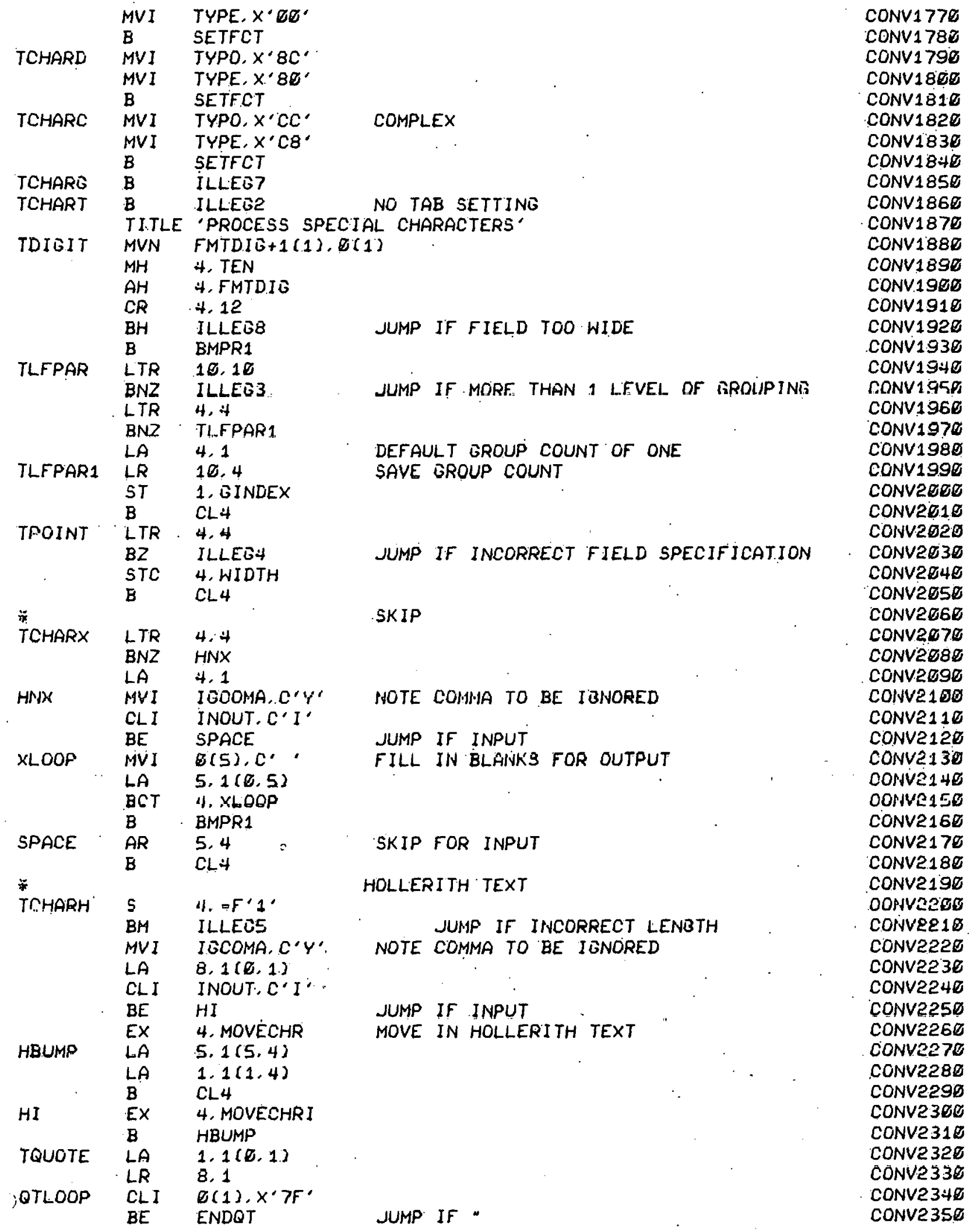




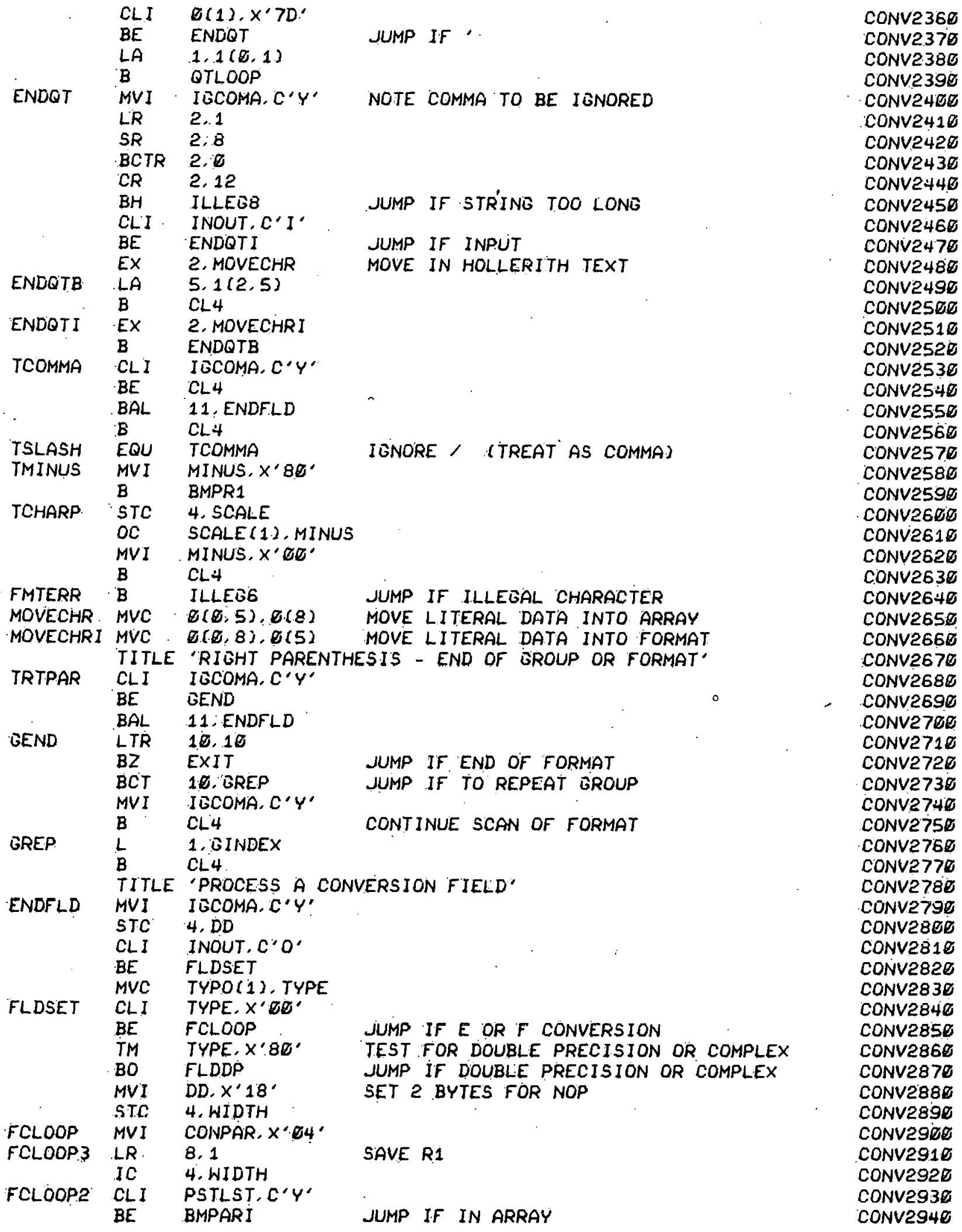




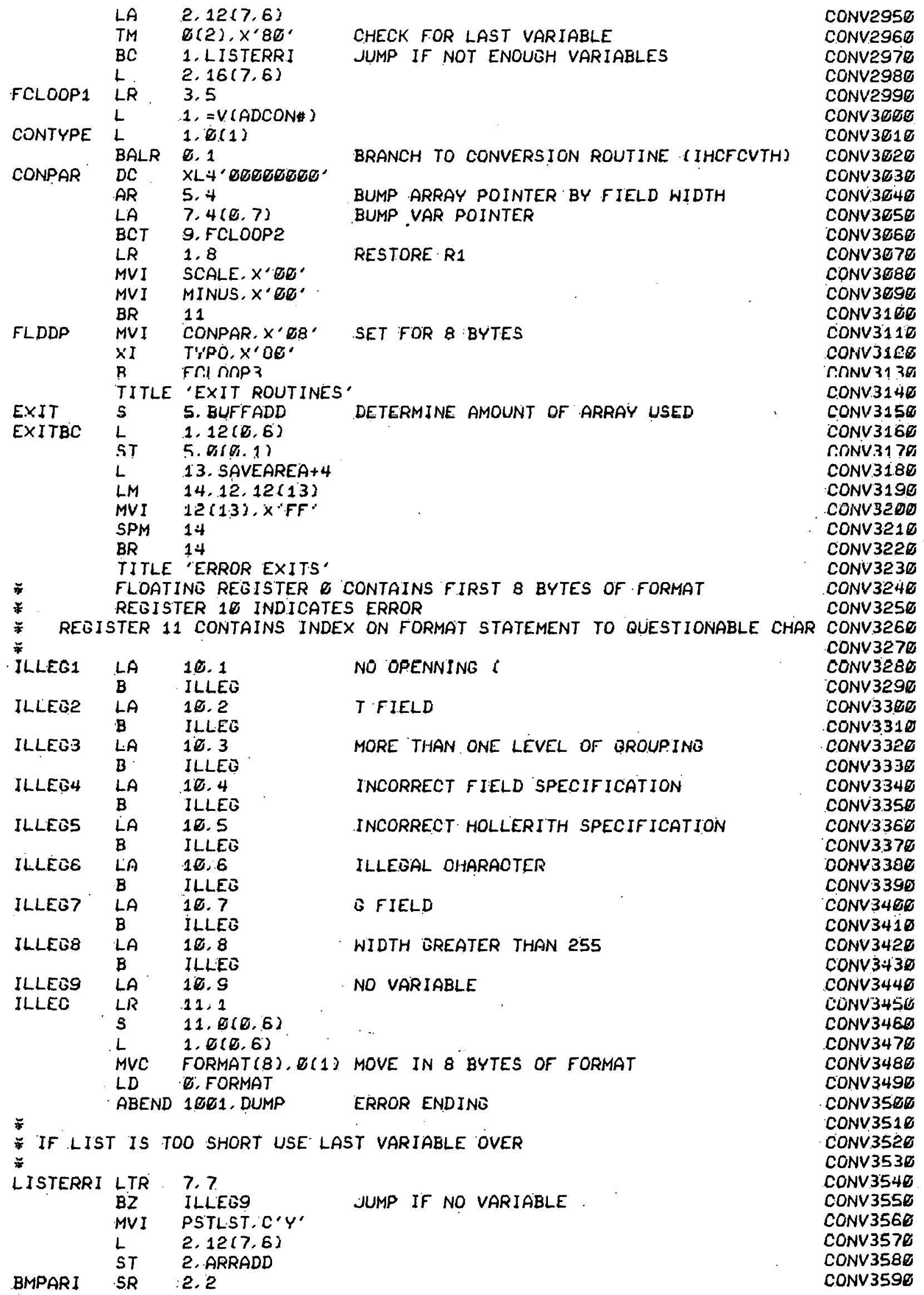




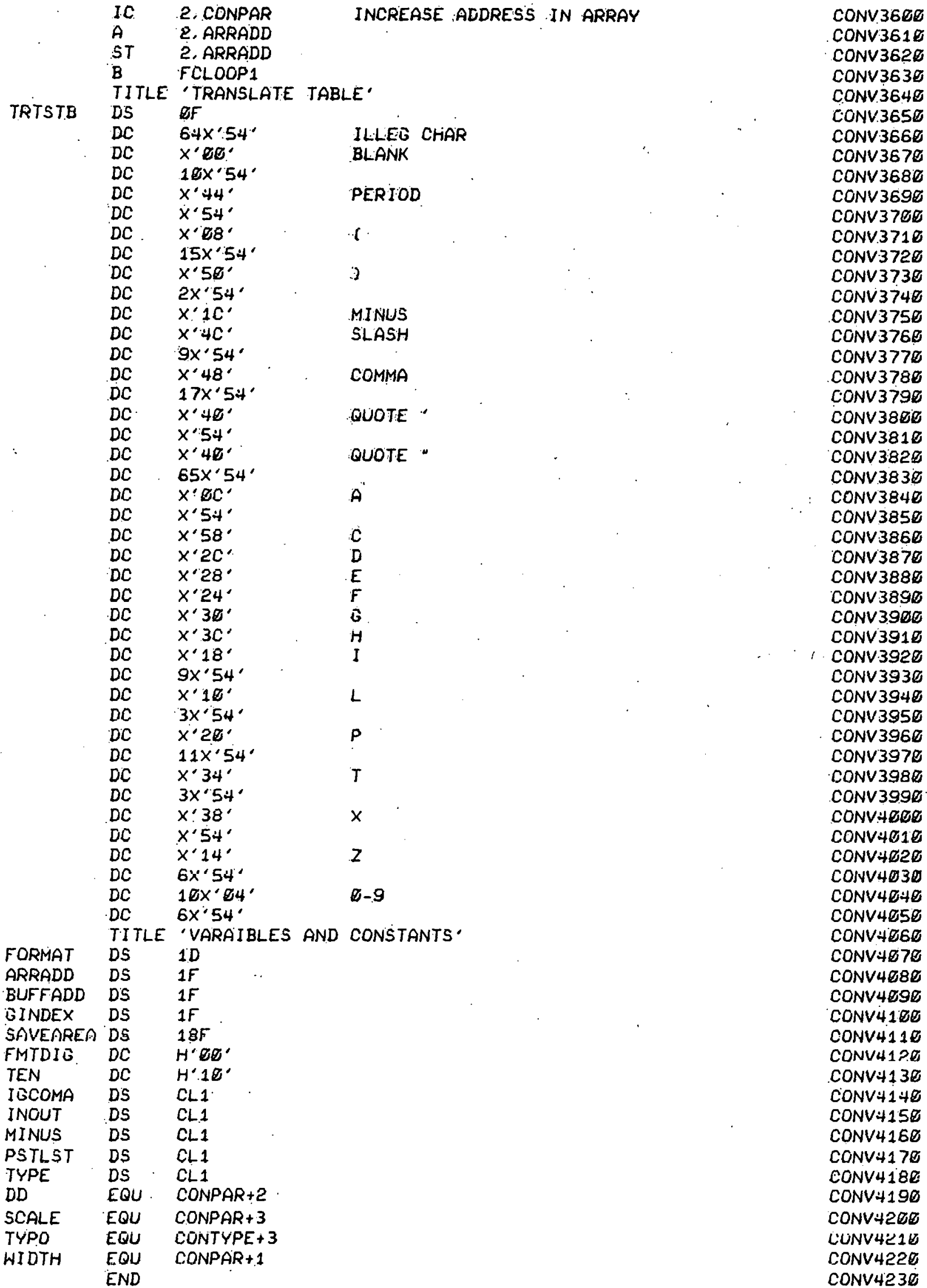


d. Subroutine LINSRT

Description:

Parameters: $\quad \mathrm{N}$

ELEM

INDEX
This subroutine sorts the source contribution for a given receptor into descending order; sorting procedure used is linear insertion.

Number of source contributions to be sorted. Array containing the source contributions. Array which will contain the ordered indices after the sort is completed; only the indires are "mnved" during the sort..

SUBROUTINE LINSRT (N, ELEM, INDEX)

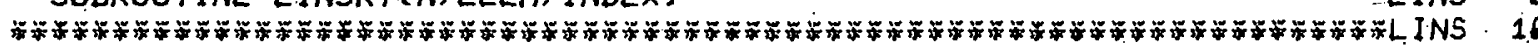
SUBROUTINE "SORTS"A LIST OF ELEMENTS INTO DECREASING ORDER USING LINS $2 \theta$ LINEAR INSSERTION SORT. ONLY THE "INDEX" LIST IS REORDERED-NOT LINS 38 THE ACTUAL LIST ELEMENTS. LINS 48

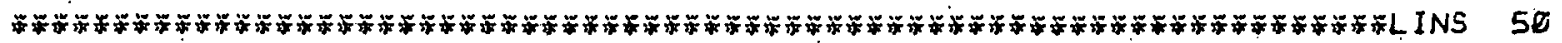
DIMENSION ELEM(N). INDEX(N) . LINS 60

IF (N .LE. 1) RETURN LINS 70 $N M 1=N-1$

DO $1 E I=1$. NM1

$I 1=$ INDEX (I)

$I 2=\operatorname{INDEX}(I+1)$

C STORE ELEMENT IN TEMPORARY LOCATION. TEMP = ELEM II2?

$L I M=I=I$

FIND PROPER PLACE FOR ELEMENT IN PRECEDING LIST

DO $4 J=1, L I M$

$I M J=I-J$

$I 3=$ INDEX IIMJ)

IF (ELEM(J3) GT. TEMP) GO TO 8

INDEX $(I M J+1)=$ I 3

4 CONTINUE

C "INSERT" ELEMENT

6 INDEX $(1)=I 2$

GO TO 10

C "INSERT" ELEMENT

8 INDEX $(I M J+1)=I 2$

$c$

c

18 CONTINUE

RETURN

LINS 120

LINS .136

L.INS 140

LINS 150

LINS 168

L.INS 170

LINS 180

LINS 190

LIPAS EQG

LINS 210

LINS 22E

LINS 230

LINS 248

LINS 250

LINS 260

L LN'S E'B

LINS 280

LINS 298

LINS 308

LINS 310

LINS 320

LINS 330

LINS 340

LINS 350

LINS 360

LINS 370

END

LINS 386 
e. MAIN Program

Description:

Input: NAMELIST, 'INDATA'

Output:
NAMELIST, 'INSORC'

autput:
The main program inputs all data, and modifies calculation parameters as specified through input or initial values. It initiates the calculation and output of receptor concentration data through the call to POLUTT. Through calls to SEIECT and CULPLT it "selects"! the receptors and highest contributors for the culpability list.

\author{
A11 receptor locations and concentrations \\ and the "selected" receptors (by number) in \\ the culpability list are output, if re- \\ quested.
}




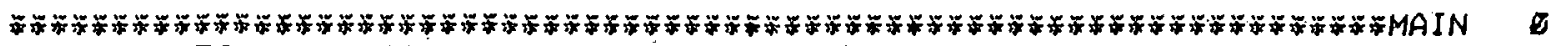

ARGONNE STEADY STATE MODEL. JANUARY 1972.

PROGRAM CALCULATES GROUND LEVEL CONCENTRATIONS AT DESIGNATED

MAIN 10

RECEFTORS FOR A PARTICULAR SET OF METEOROLOGICAL CONDITIONS;

NAMELY, SEASON, STABILITY CLASS, WIND DIRECTION, AND WIND SFEED. MAIN 40

PROGRAM STRUCTURE IS BASED UPON THE 'AQDM' PROGRAM.

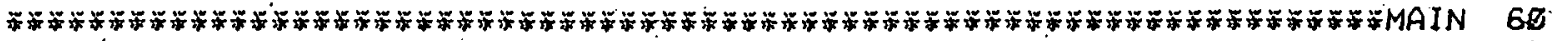

INTEGER SEA(4):STAB(5).WD (16).WS(6) MAIN 90

COMMON/CULP/IAPERT. NCSORC

COMMON/PGLTYP/IPOLU1. IPOLUE

COMMON/RCPCON/NRECEF, CFOLUT $\{2,346\}$

COMMON/RECPTR/DM. ISTAB. IWD. IWS, LINCT, NSORCE, S. BACKGR (2),

* QSORCE (1EEE), RECEPT $(2,340)$, SORCE $(7,18 B E)$

COMMON/SELCT/NSELC. ISELC (2, 10), POLUTC $(2,10)$

COMMON/TITLES/LABEL. TITLE1. REGION(18)

DIMENSION ATEMF (4), DEDAYF (4),DELX (4), DELY (4), DPTHMX (4),

1 EMRATE (2, 1EEE), FALL (3, 16EE), ICONP (10), ICONS (18), INERX (4), INCRY (4), MSEA (4), MSTAB (5), MWDSF.(16), NADJS (4), RBASE (2), SPRING (3, 10E0), STABCL (5), SUMMER (3, 10EO)! TI TLE2 (24), WINDR (16), WINTER (3, 10EQ), XRECEP $(2,20)$

EQUIVALENCE (TITLE1(1), TITLE2(1)), (LABEL(1), METSET(1))

$c$

DATA SEASON/BHDEC-FEB , BHMAR-MAY : BHJUNE-AUG, 8HSEPT-NOV/

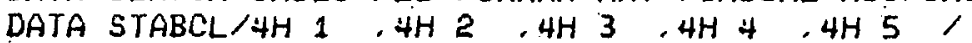

DATA WINDR/4HN, $4 \mathrm{HNNE}, 4 \mathrm{HNE}, 4 \mathrm{HENE}, 4 \mathrm{HE}, 4 \mathrm{HESE}, 4 \mathrm{HSE}$,

$14 \mathrm{HSSE}, 4 \mathrm{HS}, 4 \mathrm{HSSW}, 4 \mathrm{HSW}, 4 \mathrm{HWSW}, 4 \mathrm{HW}, 4 \mathrm{HWNW}, 4 \mathrm{HNW}$,

2 HHNNW

DATA WINDSP $/ 8 H \quad \square-3,8 H+6-6,8 H 7-10.8 H 11-16$.

* 8H17 - 21, 8HOVER $21 /$

DATA MSEA/ $4 \mathrm{HH}, 4 \mathrm{HS}, 4 \mathrm{HN}, 4 \mathrm{HF}$,

DATA MSTAB/4HVU, 4HMU . 4HSU . 4HNT, 4HST,

DATA MHDSP.SHH $3.4 H 6$. $4 H 1 Q .4 H 16.4 H 21.4 H 25$ ।

DATA ATEMP, DEDAYF, DPTHMX/271.89; 283.6, 296.89. 283.6.

$12.16 ; 1 . \dot{E}, \quad$ B.E4, E.8.

6E0.0. 850.0. 1180.8. 850.01

DATA I.SEA.I:STAR. L WD. I. W.S/ 4 KO /

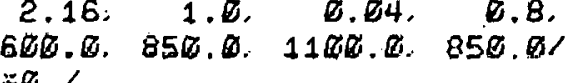

DATA DELTA, IADD, IPUNCH, MSRC, NCASE, NHIGH, NPOLUT, REASE, RCFR/

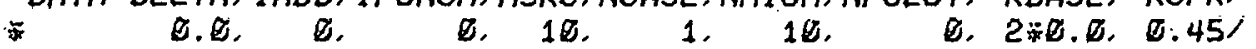

C

NAMELIST/INSORC/NSORCE, NCSORC, SORCE, QSORCE

NAMEL IST/INDATA/REEION, METSET, REASE, DELTA, INCRX, INCRY, NDELX.

MAIN 100

MAIN 110

MAIN 120

MAIN 130

MAIN 140

MAIN 150

MAIN 166

MAIN 170

MAIN 180

MAIN 190

MAIN $2 E O$

MAIN E10

MAIN 220

MAIN 23E

MAIN 240

MAIN 250

MAIN 26E

MAIN 270

MAIN 280

MAIN 298

MAIN 36E

MAIN 310

MAIN 328

MAIN 330

MAIN 340

MAIN 350

MAIN 360

MAIN 379

MAIN 380

MAIN 398

MAIN 400

MAIN $\$ 10$

MAIN 420

1 DELX, NDELY, DELY, IADD, XRECEP; NPOLUT, BACKGR, RCFR, NCASE, IPUNCH, MAIN $43 E$

2 LSEA, SEA, ATEMP, DEDAYF, DPTHMX 'WINTER, SPRINE, SUMMER, FALL.

3 LSTAB, STAB, LWD, WD. LWS,WS, NSELC. ICONS. ICONP, NHIGH, MSRC,

C it TAPERT

CWINITIALIZE ARRAYS TO ZERO

DO $1 \mathrm{~J}=1,106 \mathrm{~B}$

QSORCE $(\lambda)=\theta, Z$

DO 1 I $=1,3$

WINTER $(I, J)=0.0$

SPRINE(I.J) $=\mathbb{\theta} . \mathbb{E}$

$\operatorname{SUMMER}(1\rfloor,)=\mathbb{Z} . \mathbb{Z}$

FALL $(I, J)=\varnothing .8$

1 CONTINUE

$c$

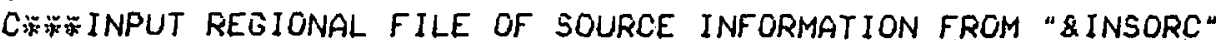

MAIN 448

MAIN 450

MAIN +68

MAIN 470

MAIN 480

MAIN 430

MAIN 580

MAIN 510

MAIN 520

MAIN 530

MAIN $5 * 8$

MAIN 550

MAIN 560

MAIN 570

MAIN 580 
READ (10, INSORC)

IF (NSORCE . GT. E) GO TO 5

WRITE (6. 4EE) NSORCE

GO TO 280

$c$

REDUCE "QSORCE" TO 12\% IF SORCE (7. ISORCE) IS 4911; OTHERWISE TO 20\%

5 DO 1O ISORCE $=1$. NSORCE

QSORCE (ISORCE) = QSORCE (ISORCE)

IF (SORCE (7. ISORCE) .EQ. 4911. O)

CONTINUE QSORCE (ISORCE) = QSORCE (ISORCE) $\$ .60$

16. CONTINUE

C

IF (NCSORC ,EQ. NSORCE) GO TO 25

. NAREA $=$ NCSORC +1

DO 20 ISORCE = NAREA. NSORCE

C CONVERT AREA TO SIDE LENGTH OF EQUIVALENT SQUARE

SORCE (3. ISORCE) $=1$. . EE +3 $\%$ SQRT (SORCE (3. ISORCE).

20 CONTINUE

c

C

C

CONVERT EMISSION RATES FROM 'TONS/DAY' TO 'MICROGRAMS/SECOND' AND SAVE FOR POSSIBLE SEASONAL ADJUSTMENT

25 DO 3E ISORCE $=1$. NSORCE

502

EMRATE (1. ISORCE) = SORCE (4. ISORCE) 1.85E+7

C PARTICULATE

EMRATE (2, ISORCE) = SORCE (5, ISORCE) $1.65 E+7$

30 CONTINUE

CW INPUT CALCULATION AND CONTROL PARAMETERS FROM "ZINDATA"

READ (5. INDATA)

NCASES = LSEA LSTAE LWD LWS

IF (NCASES GT. Q) GO TO 35

WRITE(6, 41E) LSEA, LSTAB, LWD, LWS

C GO TO 280

35 NCASE = NCASE - 1

IF (NPOLUT ,EQ. 1) IPOLUE = 1

IF (NPOLUT .EQ. 2) IPOLU1 $=2$

NHIGH $=$ MINE (10. NHIGH)

$M S R C=M I N E(2 D, M S R C)$

CWCREATE THE RECEPTOR GRID WITH ORIGIN AT RBASE

IF (DELTA .EQ. E.E) GO TO 40

$D E L X(1)=D E L T A$

$c$

DELY(1) = DELTA

40 IRLCEP $=0$

$x=\operatorname{RBASE}(1)-\operatorname{DELX}(1)$

DO $6 E N X=1$, NDELX

DELTAX $=$ DELX $(N X)$

c

INCR $1=\operatorname{INCRX}(N X)$

DO 60 LAT = 1, INCR 1

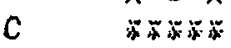

$Y=$ RBASE (2) - DELY(1)

DO $5 O N Y=1$. NDELY

$D E L T A Y=D E L Y(N Y)$

c

INCRE = INCRY (NY)

DO 50 LON $=1$. INCR2

MAIN 590

MAIN $6 E \mathbb{E}$

MAIN 610

MAIN 620

MAIN 630

MAIN 640

MAIN 650

MAIN 66E

MAIN 670

MAIN 680

MAIN 690

MAIN $7 E E$

MAIN 710

MAIN 720

MAIN 736

MAIN 74E

MAIN 758

MAIN 760

MAIN 770

MAIN 78E

MAIN 790

MAIN $8 E D$

MAIN B1E

MAIN 820

MAIN 830

MAIN 840

MAIN 850

MAIN 860

MAIN 878

MAIN 880

MAIN 890

MAIN $9 E 0$

MAIN 910

MAIN 920

MAIN 930

MAIN 948

MAIN 950

MAIN 960

MAIN 970

MAIN 980

MAIN 990

MAIN1ERE

MAIN101E

MAIN1E20

MAIN1E3E

MAIN1E4E

MAINIESE

MAIN1E60

MAIN1E70

MAIN1E8E

MAIN1098

MAIN11EE

MAIN111E

MAIN1120

MAIIV1 130

MAIN1 140

MAIN1150

MAIN1.16日

MAIN1178 


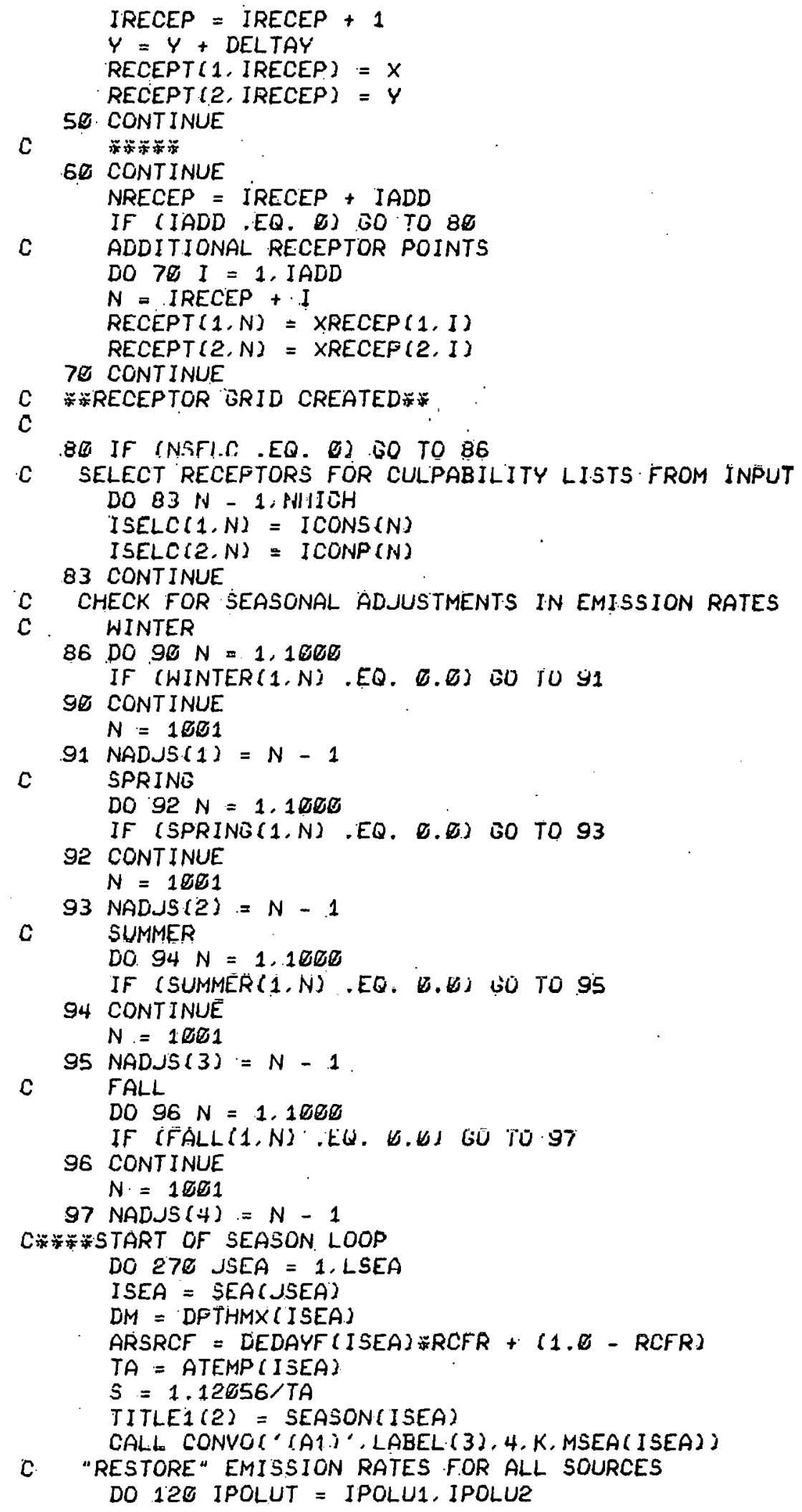

MAIN1 18E

MAIN1 190

MAIN12EG

MAIN1210

MAIN1220

MAIN1230

MAIN1240

MAIN1250

MAIN1260

MAIN1270

MAIN128B

MAIN1290

MAIN1300

MAIN1 310

MAIN1 320

MAIN1 33E

MATN1 340

MAIN1 350

MAINL3EE

MAIN1370

MAIN1 380

MAIN1 390

MAIN1"EO

MAIN1410

MAIN1420

MAIN1430

MAIPI 140

MAIN1458

MAIN146E

MAIN1 470

MAIN1 $+8 B$

MAIN1498

MAIN1 50E

MAIN1510

MAINISED

MAIN1530

MAIN1540

MAINISED

MAIN156E

MOIN15 70

MAIN158E

MAIN1590

MAIN16ER

MAIN1610

MกIN1628

MAIN1630

MAIN1640

MAIN1650

MAIN1660

MAIN1670

MAIN1680

MAIN169R

MAINI $70 E$

MAIN171E

MAIN1 720

MAIN1 730

MAIN1 740

MAIN1750

MAIN1760 
$K=$ IPOLUT +3
POINT SOURCES
DO 1 IGO ISORCE $=1$, NCSORC

100 CONTINUE

SORCE (K, ISORCE) = EMRATE (IPOLUT, ISORCE)

MAIN1778

MAIN1780

MAIN1798

MAIN18E0

MAIN1810

MAIN182G

C AREA SUURLES : MUDIFY EMISSION RATE BY ARSRCF DO 11.0 ISORCE = NAREA. NSORCE

SORCE (K, ISORCE) = EMRATE (IPOLUT, ISORCE) ARSRCF

c

110 CONTINUE

120 CONTINUE

IF (NADJS. (ISEA) EQ. E) GO TO 220

CWSEASONAL ADJUSTMENTS OF EMISSION RATES

NADJ = NADJS (ISEA)

DO 210 IPOLUT $=$ IPOLU1. IPOLU2

$K=$ IPOLUT +3

$L=$ IFOLUT +1

C SELECT SEASON

GO TO (13E.150,170.19E). ISEA

C WINTER

130 DO 14E $N=1$, NADJ

ISORCE = WINTER $(1, N)$

SORCE (K, ISORCE) = SORCE (K, ISORCE) WINTER (L,N)

14E CONTINUE

C

GO TO 210

SPRINE

150 DO 16E $N=1$. NADJ

ISORCE = SPRING(2, N)

$\operatorname{SORCE}(K, I S O R C E)=\operatorname{SORCE}(K, I S O R C E) \neq S P R I N G(L, N)$

16E CONTINUE

GO TO 210

C SUMMER

17E DO 18E $N=1$, NADJ

ISORCE = SUMMER (1.N)

SORCE (K. ISORCE) = SORCE (K. ISORCE) * SUMMER (L.N)

180 CONTINUE

60 TO 210

$c$

FALL

$190 D O 20 E N=1$. NADJ

ISORCE $=$ FALL (1,N)

SORCE (K, ISORCE) = SORCE (K, ISORCE) $\approx F A L L(L, N)$

c

2G0 CONTINUE

210 CONTINUE

C ALL SEASONAL ADJUSTMENTS COMPLETED

C洋和

220 DO 270 JSTAB = 1. LSTAB

$I S T A B=S T A B(J S T A B)$

TITLE2 (1E) = STABCL (ISTAB)

CALL CONVOI'(A2)', LABEL (3), 6,K, MSTAB (ISTAB))

C START OF WIND-DIRECTION LOOP

DO $270 \mathrm{JWD}=1$. LWD

$I W D=W D(J W D)$

$\operatorname{TITLE2}(16)=$ WINDR (IWD)

CALL CONVO(' $(A 3)$ ', LABEL (3), 9,K,WINDR (IWD) )

C

DO 270 JWS = 1. LWS

IWS $=$ WS (JWS $)$

MAIN1830

MAIN1840

MAIN1850

MAIN1860

MAIN1870

MAIN1880

MAIN189E

MAIN19E0

MAIN191E

MAIN1928

MAIN1930

MAIN194E

MAIN1950

MAIN1960

MAIN1970

MAIN198E

MAIN1998

MAIN2EEE

MAIN2Z1E

MAIN2E2E

MAIN203E

MAIN2Q46

MAIN2058

MAIN2060

MAI N2Q70

MAIN2080

MAIN209E

MAIN21ED

MAIN2110

MAIN212E

MAIN2130

MAIN214E

MAIN2,150

MAIN2160

MAIN2170

MAIN218E

MAINE190

MAIN22BE

MAIN2218

MAIN2220

MAIN2230

MAIN224E

MAIN2250

MAIN2260

MAIN2270

MAIN228E

MAIN2290

MAIN2300

MAINE310

MAIN2320

MAIN2338

MAIN2348

MAIN2350 
TITLE1 (11) $=$ WINDSP. (IWS)

$c$

CALL CONVO('(A2)', LABEL(3), 13,K, MWDSP(IWS) )

MAIN236E

MAIN2370

MAIN2380

L.INCT $:=100$

NCASE $=$ NCASE +1

CALL' CONVO (' (I3)', LABEL (5), E. K. NCASE)

C CALCULATE AND OUTPUT. GROUND-LEVEL CONCENTRATIONS FOR ALL RECEPTORS DO 23E IRECEP $=1$. NRECEP

CALL POLUT (IRECEF, .FALSE.)

MAIN2398

MAIN24EQ

MAIN2410

MAIN2420

MAIN2430

MAIN2440

230 CONTINUE

MAIN2450

IF IIPUNCH EQ E) GO TO 250
C OUTPUT RECEPTOR CONCENTRATION DATA ON UNIT 'IPUNCH'

MAIN246E

MAIN2478

DO 240 IRECEP $=1$. NRECEP

MAIN2480

MAIN2490

WRITE (IPUNCH, 3EG) (RECEPT (L, IRECEP), L=1,2); (CPOLUT (IPOLUT, IRECEP.) MAINOSEE

* $\therefore$ IFOLUT $=$ IPOLU1, IPOLU2)

2HE CONTINUE
MET SET IDENTIFIER

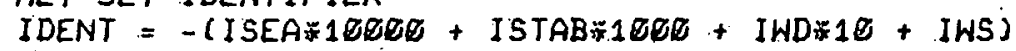

WRI TE (IPUNCH. 31E) IDENT

CHE "SELECT" RECEPTORS FOR CULPABILITY LIST

25E CALL SELECT (NHIBH)

$c$

IF (IPUNCH .EQ. E) 60 .TO 260

C RECEPTORS FROM THE CULPABILITY LIST

WRITE (IPUNCH. 328) (ISELC (1,K), K=1.NHIGH)

WRI TE (IPUNCH, 32E) (ISELC (2,K): $K=1$. NHIGH)

CW"GENERATE" CULPABILITY LIST"

$c$

260 CALL CULPLT (NHIGH, MSRC.)

27E CONTINUE

C

$c$

C

280. STOP

3EE FORMAT (2PEFB., $1 \times, 2(2 P F 9,0))$

31.0 FORMAT $(17)$

उEO FORMAT (1QIG)

4EO FORMAT (1HE. 1EX, 'RLLIUNAL SOURCE FILE ERROR', $11 H, 16 X$,

* 'NSORCE $=$ ', 16J

41E. FORMAT (1HE. 1EX. 'INPUT DATA ERROR'//1H, 12X,. LSEA =', IG'.

1. $1 H, 12 X, ' L S T A B=\prime, I 6 / 1 H, 12 X, ' L W D={ }^{\prime}, I 6 \prime$

C

$2 \quad 1 H, 12 x$, LWS $=\prime, 16)$

END

MAIN2510

MAIN2520

MAIN2530

MAIN2540

MAIN2550

MAIN2560

MAIN2570

MAIN2580

MAIN2590

MAIN26EE

MAIN2610

MAIN2620

MAIN2630

MAIN2640

MAIN2650

MAIN2660

MAIN2670

MAIN2680

MAIN2690

MAIN27EE

MAIN271E

MAIN272E

MAIN2730

MAIN2748

MAINP 75\%

MAIN276E

MAIN2778

MAIN2780

MAIN279E

MOINPRRG 
f. Subroutine POLUT

Description:

Parameters: IRECEP

INDSRC

Output:

This subroutines computes the ground-level concentrations for all receptors and outputs a table containing the receptor concentration data. It is also used to calculate and store the contribution from each source for a selected receptor. The calculation "mode" of this routine is controlled through the input variable INDSRC.

Number of the receptors for which concen-. tration data or source contributions will be calculated.

Control for calculation "mode" of the routine;

.FALSE. for receptor concentrations .TRUE. for source contributions A table containing the receptor number, its location, and its $\mathrm{SO}_{2}$ and/or particulate concentration levels. 
SUBROUTINE POLUT(IRECEP, INDSRC)

POLU E

C

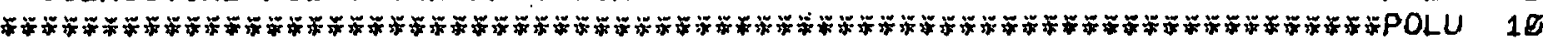

REAL $\div 8$ TITLE1(12). LABEL(5)

INTEGER SORID

LOGICAL INDSRC

COMMON/FOLTYP/IPOLU1. IPOLU2

COMMON/RCPCON/NRECEP, CPOLUT $(2,348)$

COMMON/RECFTR/DM, ISTAB. IWD. IWS: LINCT, NSORCE, S, BACKGR(2).

* QSORCE (1EEE), RECEPT (2, 340), SORCE (7, 10BE)

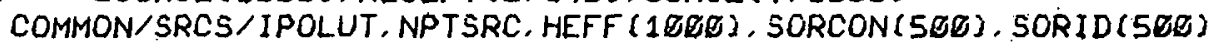

COMMON/TITLES/LABEL. TITLE1, REGION(18)

DIMENSION $A(7,6), B(7,6), C(3,5), D(3,5), \operatorname{TIME}(7), \operatorname{COSWD}(26)$,

* SINWD (16), UU(6)

EQUIVALENCE (IWNDIR. IWD)

C

\begin{tabular}{|c|c|c|c|c|c|c|c|c|}
\hline DATA & $\begin{array}{r}\text { A/. } 17122, \\
.11662, \\
.81338 \\
.01338 \\
.01338 \\
.01338 \\
\text { B/1.2098, } \\
1.2864 \\
1.5922 \\
1.5922 \\
1.5822 \\
1.5922\end{array}$ & $\begin{array}{l}.27668, \\
.39953 \\
.16640 \\
.16640 \\
.16640 \\
.16640 \\
1.0572 \\
.99275 \\
1.1195 \\
1.1195 \\
1.1195 \\
1.1195\end{array}$ & $\begin{array}{l}.41219, \\
.41219 . \\
.41219 . \\
.41219, \\
.41219 . \\
.41219 . \\
.92365 . \\
.92365 . \\
.92365 . \\
.92365, \\
.82365 . \\
.92365\end{array}$ & $\begin{array}{l}.51921, \\
.57145, \\
1.0813, \\
2.2830, \\
2.3333, \\
5.6881, \\
.84130 \\
.82449 \\
.73217 \\
.63883 . \\
.63646, \\
.55816 .\end{array}$ & $\begin{array}{l}.50963 \\
.76485 \\
1.9467 \\
2.9850 \\
5.7990 \\
14.599 \\
.79689 \\
.72571 \\
.59047 \\
.53798 \\
.46497 \\
.37541\end{array}$ & $\begin{array}{l}.47639, \\
.71936 . \\
2.3901 . \\
3.8684 . \\
16.897 \\
64.577 . \\
.76308, \\
.69082 . \\
.51700 . \\
.45686 . \\
.29621 . \\
.16667 .\end{array}$ & $\begin{array}{l}.52140 \\
.88886 \\
1.8877 \\
6.7452 \\
28.673 \\
54.149 \\
.69839 \\
.68486 \\
.49583 \\
.33677 \\
.21517 \\
.12177\end{array}$ & $\begin{array}{l}\text { POLU } \\
\text { POLU } \\
\text { POLU } \\
\text { POLU } \\
\text { POLU } \\
\text { POLU } \\
\text { POLU } \\
\text { POLU } \\
\text { POLU } \\
\text { POLU } \\
\text { POLU } \\
\text { POLU }\end{array}$ \\
\hline
\end{tabular}

DATA $C / 3 \# 110.0,3 \% 60.0,2 * 33.0,40.0,2 \% 21.5,36.0,2 \$ 14.0,23.5 / P O L U 270$

DATA D/1.0. 2*1.89, 3\%E.92, 0.80,0.61, 0.53, 0.76, 8.56, E.35, POLU 28E

* D.78, 0.53,0.30/

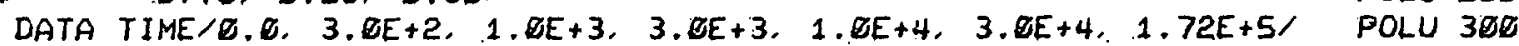

C $\quad \operatorname{COSWD}($ IWNDIR) $=\operatorname{COS}((P I F L O A T(I W N D I R-1)) / 8)$

DATA COSWD/1.0. .92388,.78711,.38268,0.0,-.38268,-.78711,-.92388,

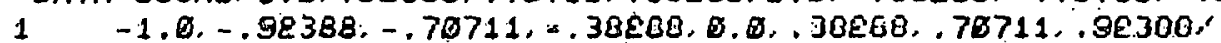

C SINWD (IWNDIR) $=S I N($ (PI FLOAT (IWNDIR-1.) $/ 8)$

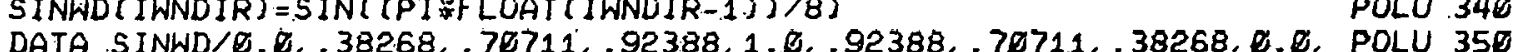

$1-.38268,-.70711,-.92388,-1.0,-.92388,-.70711,-.382681$

DATA III/ .67956. ?.4587?. 4.47640. 6.92912, 9.61136. 12.51712/

DATA GDSCAL.PI4.PI8, QSCALE/1000.0, 0.7853982, ש.3926991, 1.ש/

P.OLU 310

POLU 320

POLU 330

POLU 360

POLU 378

POLU 380

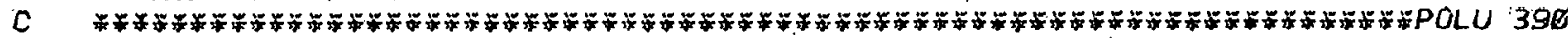

IF (INDSRC) BO TO 18B

POLU 4EO

POLU 410

POLU 420

CPOLUT (1. IRECEP) $=E \cdot E$

CPOLLUTSP. IRESCF.P] $=$ G.G

POLU .430

POLU 440

LOOP ON SOURCE

16E DO 3GE ISORCE = 1. NSORCE

C GEOMETRY BASED UPON AQDM

SDIAM = SORCE (3, ISORCE)

SKAAD $=0.5$ SDIAM

DNWIND = GDSCAL ( $(S O R C E(2, I S O R C E)-$ RECEPT( $)$, IRECEP) )

POLU 450

POLU 46E

POLU 470

POLU 48E

POLU 490

POLU 5EE

2 COSWD (IWNDIR) + (SDRCE(1.ISORCE) - RECEPT.(1, IRECEP))

SINWD (INNDIR) )

$x=$ DNWIND + SDIAM/PI8

IF (SDIAM .GT, 1ER,) EO TO 110

IF (X) 300, 300.120

110 IF ( (SRAD+DNWIND) LE. O.Q) 30 TO 368

$12 \theta$ CXWIND = EDSCAL * ABS ( (SORCE (2, ISORCE) - RECEPT(2, IRECEP)) -

*POLU 518

POLU 520

POLU 530

POLU 54E

POLU 550

POLU $5 \in E$ 
2

$Y=X \ddot{x P I E}$

IF. $\{Y$. LE. CXWIND) 00 TO 380

IF (SRAD. ET. AESIDNWIND:) GO TO 138

If (SDIAM.LE. (DNWINDIXIB)) BO TO 148

$Q=Q S C A L E \approx(Y Y-S D I A M) / S D I A M)$

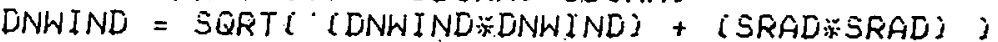

$X=2.8 \%$ DNWIND

IF [CXWIND - CSRAD+Y) 150.150, 3EE

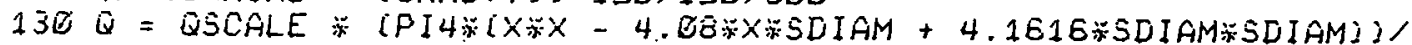

$\ddot{x}$ [SRAD:SRAD:16.8)

DNWIND = SINWD $(\overline{3}) \because$ (DNWIND + SRAD

$X=2 . \mathbb{E} *$ DNWIND

IF (CXWIND - SRAD) 15B, 158, 38E

$14 B \bar{Q}=Q \bar{Q} S C A L E$

158 If $(X . L T .108) x=$.

C莯洪END OF GEOMETRY

c

$U=U U$ (INS)

$L=I S T A B$

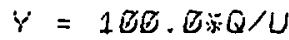

IF (Y.LE. E.B) EO TO $3 B E$

C:

$H S$ = SORCE (E. I SORCE)

IF (QSORCE IISORCE) NE. B. B) BO TO 168

$\mathrm{PHT}=\mathrm{HS}$

60 TO 200

C $\quad 1.879167 E-7=3.7 E-5: .87 / 24$

$168 \mathrm{~F}=1$. B T9167E-7 $\dddot{\pi}$ QSORCE IISORCE:

IF (ISTAE . BT. 4) EO TO 170

C STABILITY CLASSES $1-4$

$D E L H A=1.6 \% F$ F

$P H T=H S+D E L H A$

IF (PHT. LE. DM) GO TO $2 B E$

C EFFECTIVE STACK HEIGHT GREATEK THAN LID HEIGHT : CALCULATE "NEW" EFFECTIVE STACK HEIEHT USING PLUME RISE FOR STABILITY CLASS 5

STAEILITY CLASS 5

178 IF (IWS .NE. 1 ) 60 TO 180

C IWS $=1$

DELHM $=5.8 *$ F F

BO TO 198

C IWS $\wedge=1$

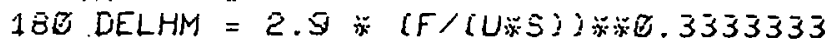

IJE FIIT - HS + DELHMI

IF (FHT. BT. DM) BO TO 380

C USE LID HEIGHT FOR EFFECTIVE STACK HEIGHT IN STAEILITY CLASSES $1-4$ IF IISTAE. NE. S: PHT = DM

C:

ZOE IF (DNWIND. QE. 18BE.) GO TO 210

IF IDNWIND . LT. $18 B . ;$ DNWIND $=1 E E .0$

CWX

21E TSEC = DNHIND. LU

DO $215 M=2.7$

IF ITSEC .LE. TIMEIMI) 60 TO 220

215 CONTINUE

$M=\varepsilon$

$c$

BO TO 230

$220 M=M-1$

POLL 590

POLU ERE

POLU 610

POLU 620

POLL' 630

POLU 64E

POLU 658

POLU 6ER

POLU 678

POLU GẼ

POLU ESE

POLU 7EQ

POLU 718

POLU 720

POLU 730

POLU 748

POLU 758

POLU 7EE

POLU 778

POLU 780

POLU 790

POLU BGG

POLU B1.0

POLU B2E

POLU 830

POLU 840

POLU 858

POLU 868

POLU 87D

POLU 88R

POLU 898

POLU 9ED

POLU 918

POLU 928

POLU 938

POLU 948

POLU S5E

POLU 968

POLU 978 .

POLU SËE

POLU 998

POLUAGGR

POLU1E1E

POLUIOEC

POLU1E30

POLU1E48

POLU1ESE

POLU106e

POLU1E78

POLU188E

POLU1EGE

POLU1100

POLU1118

POLU1120

POLU1130

POLU114E

POLU1150

POLU1168

POLU117E 
c $0.87055=(6 \theta / 120) \div 0.2$

POLU1180

$230 S T G Z=(A(L, M) \neq T S E C=B(L, M)) * 0.87655$

POLU1198

XXKM = DNWIND $\because 1 . E E-3$

$I=1$

If $(X X K M, .6 T, 1) I=$.

If (XXKM GT. IE.) I $=3$

$J=\operatorname{MAXE}(L-1,1)$

$c$

SIGTZ $=(C(I, J) \neq X X K M \approx D(I, J)) 1,431$

$1.431=(60 / 10) \div 0.2$

POLU12ES

POLU121E

POLU122E

POLU123E

POLLU1248

POLU125E

POLU126E SIGZ = AMAKI (SIGZ, SIGTZ)

C \#END OF DISPERSION CALCULATION - CALCULATE CONCENTRATION ARG1 $=(-Q .5 \% P H T$ THT $) /(S I G Z * 5 I G Z)$

IF (ABS (ARG1) . GT. 6E.) GO TO 3EB

C DETERMINE X-CRITICAL FROM 2.17 IF (SIGTZ .EQ. SIGZ) GO TO 240

$c$ $1.88909=0.87855 \div 2.17$

$T S E C=(D M /(1.88909=A(L, M)))(1, E / B(L, M))$

$X C R I T=U$ TSEC

.60 T0.250

$c$

$24 E \times X K M=(D M /(3,18527 \% C(1, J)) 2 \div(1 . E / D(1, J))$.

$3.10527=1.431 \div 2.17$

$X C R I T=1 . E E+3 \approx X X K M$

c

258 IF (X .LE. XCRIT) 60 TO 260

C. UNIFORM MIXING IF $X>=2 \pi X C R I T$

$X$ CRITE $=2.0 \times$ XCRIT

$C H I=(E . E 255 \div Y) /(D M \div X)$

IF. (X .GE. XCRIT2) 60 TO 270

C LINEAR INTERPOLATION IF XCRIT $<x<2 F X C R I T$

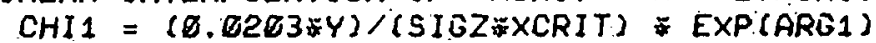

CHIE $=(B . E 255 \div Y) /(D M \times C R I T 2)$

$C H I=C H I 1+($ (CHI2 - CHI1) XCRIT $)=(X-X C R I T)$ GO TO 278

C GAUSSIAN IF $X$ R.: XCRIT

260. $\mathrm{CHI}=(E .0203 \% Y) /(S I E Z \% X) * \operatorname{EXP}(A R G 1)$

c HALF-LIFE MODIFICATION FOR SO2

$270 \mathrm{ALIFE}=\operatorname{EXP}(-0.693(\mathrm{DNWIND} / U) / 18800: 0)$

c IF (INDSRC) OO TO $89 Q$

DO 286 IPOLUT $=$ IPOLU1. IPOLU2

CONC $=$ CHI $\#$ SORCE (IPOLUT +3. ISORCE)

IF (IPOLUT .EQ. 1) CONC = CONC ALIFE

CPOLUT (IPOLUT, IRECEP) $=$ CPOLUT $($ IPOLUT, IRECEP $)+$ CONC

$\varepsilon 80$ CONTINUE

GO TO 380

C

290 CONC = CHI SORCE (IPOLUT + 3. ISORCE)

IF (CONC .EQ. E.E) BO TO 3EE

NPTSRC = NFTSRC +1

SORID (NPTSAC) E ISORCE

IF (IPOLUT .EQ. 1) CONC = CONC ALIFE

SORCON(NFTSRC) $=$ CONC

C HEFF (NPTSRC) $=$ PHT

c

3EE CONTINUE

C

IF (INDSRC) RETURN

POLU1270

POLU129E

POLU138E

POLU131E

POLU1320

POLU1336

POLU1 348

POLU1 35E

POLL1 360

POLU1378

POLU1 380

POLU1 398

POLU14ED

POLU1418

POLU1 420

POLU1430

POLU1448

POLU1450

P.OLU1468

POLU1478

POLU1480

POLU1490

POLU15E0

POLU1510

POLU1520

POLU1530

POLU15HE

POLU1550

POLU1560

POLU1570

POLU1580

POLU1598

POLU16EE

POLU161E

POLUIGE

POLU1630

POLU16!I

POLU1650

POLU1660

POLU1670

POLUI600

POLU1690

POLU17Ee

POLU1710

POLU1720

POLUI73E

POLU174E

POLU175E

POLU1760 
C ADD BACKGROUND CONCENTRATION DO 310 IPOLUT = IPOLU1, IPOLU2 CPOLUT:(IPOLUT, IRECEPI = CPOLUT (IPOLUT, IRECEP) + BACKGR(IPOLUT)

310 CONTINUE

C

C THIS RECEPTOR

C

IF (LINCT .LT. 52) GO TO 440

IF (IRECEP . GT, 1 ) GO TO 4 EE

NPAGE $=1$

WRITE (6, 1EEE) LAEEL, NPAGE, REGION: TITLEI

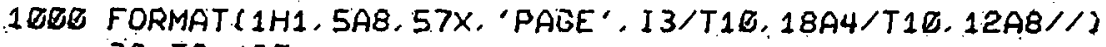

C

GO TO 420

480 WRITE $(6,1010)$

$1 E 10$ FORMAT $\left(1 H_{+}, T 10 . '\right.$

H...-.

NPAGE = NPAGE + 1

WRITE (6, 1E2E) NPAGE, REGION, TITLE1

1020 FORMAT (1H1, 97X, 'PAGE', I3/T.10, 18A4, T1E, 12A8//)

420 LINCT $=12$

WRITE $(6,101 E)$

WRITE (6, 1030)

1030 FORMAT (T1E.:I', T78, 'I')

WRITE $(6 ; 1040)$

1048 FORMATST10.' I', T28, 'RECEPTOR CONCENTRATION DATA', T78, 'I')

WRITE (6.1010)

WRITE $(6,1050)$

1058 FORMAT (T18, 'I', T21, 'I', TH5, 'I', T78, 'I') WRITE $(6,1660)$

1060 FORMAT(T1E. 'I RECEPTOR I RECEPTOR LOCATION I'.6X. 'EXPECTED ARIPOLUZG7E \#THMETIC MEAN',T78, 'I"/TIE. 'I NUMBER I'.T45.'I',T78.'I') POLU2EBE WRITE $(6,1010)$ WRITE $(6,1870)$

POLU2990

POLU21EE

1070 FORMAT(T1E. 'I', T21, 'I', T27. '(KILOMETERS)', T45. 'I', T53. '(MICROGRAMSPOLU211E 1/CU. METER.I'TT78, 'I'/T10.' I',T21, 'I',T26. 'HORIZ',6X,'VERT I', POLU212E 2 T53, 'SO2'.T64, 'PARTICULATES', T78, 'I') WRITE (6, 1610) WRITE $(6,1 E 80)$

1880 FORMAT(T1E.'I',T21.'I',T33.' I', T45.'I', T62, 'I', T78, 'I')

44\& WRITE (6, 1098) IRECEP, RECEPT (1. IRECEP), RECEPT (2, IRECEP).

* CPOLUT (1, IRECEP. I, CPOLUT (2, IRECEP)

1890 FORMAT CT16. 'I', T14, I 3, T21, 'I', 3X,F6,1, 2X, 'I', 2X,F6,1, 3X, 'I', 4X,

\$ F5. Q. T62.' I'. 3X.F5.(1).T78.' I')

LINCT. = LINCT + 1

IF (MOD (IRECEP, 3) :EQ. B) WRITE (6, 1E1E)

IF (IRECEP . NE. NRECEP) RETURN

IF (MOD (IRECEP, 3) .NE, E) WRITE $(6,1010)$

RETURN

END

POLUE1 $3 E$

POLU21 HE

POLU215E

POLU2168

POLU2170

POLU218E

POLUE19E

POI IIP?ER

POLU2210

POLU2220

POLU2230

POLU224E

POLU2250

POLUR26E 
g. Subroutine SELECT

Description:

Parameters: $\quad \mathrm{N}$
This subroutine "selects" the $N$ receptors that are to appear in the culpability list. Receptor selection is based upon either input values or the receptors with highest concentration levels. Number of receptors to be selected for the culpability 1 ist.

SUBROUT INE 'SELECT (N)

SELC

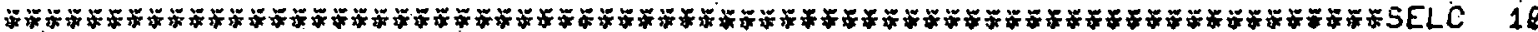
SUBROUTINE "SELECTS". N RECEPTORS BASED UPON EITHER INPUT OR THE N SELC 20 HIGHEST CONCENTRATION VALUES. THE CONCENTRATION VALUES ARE STOREDSELC 3E IN POLUTC AND THE RECEPTOR NUMBERS ARE IN ISELC.

SELC 40

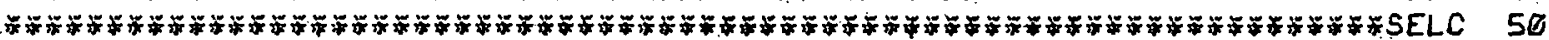
COMMON/POLTYP/IPOLU1. IPOLUR COMMON/RCPCON/NRECEP, CPOLUT (2, 34E)

COMMON/SELCT/NSELC. ISELC $(2,10)$, POLUTC $(2,18)$

SELC 6E

SELC 70

$\mathrm{C}$

DO 50 IPOLUT $=$ IPOLU1. IPOLU2

IF (NSELC. EQ. O) BO TO 15

$\mathrm{C}$

RECPTORS SELECTED BY INPUT

DO $18 I=1 . N$

TRFCP = TSFI.C.RTPOI_UT:IT?

POLUTC (IPOLUT, I) = CPOLUT (IPOLUT, IRECP)

10 CONTINUE

BO TO 58

C

RECETOR

RECEPTORS SELECTED BY N HIGHEST CONCENTRATION VALUES

15 DO $3 E K=1, N$

IRECP $=1$

DO $2 B I=2$. NRECEP

IF (CPOLUT (IPOLUT, I) . GT, .CPOLUT(IPOLUT, IRECP) I IRECP = I

20 CONTINUE

C

ISELC $(I P O L U T, K)=$ IRECP

POLUTC (IPOLUT, K) $=$ CPOLUT (IPOLUT, IRECP)

C DUMMY CONCENTRATION VALUE WITH -1.0

CPOLUT (IPOLUT. IRECP) $=-1: 0$

30 CONTINUE

C

C RESTORE CONCENTRATION VALUES

DO $4 Q I=1 . N$

IRECP $:=$ ISELC (IPOLUT, I)

CPOLUT. (IPOLUT, IRECP) = POLUTC (IPOLUT, I)

40 CONTINUE

TOCOTH

$c$

50 CONTINUE

RETURN

END

SELC 80

SELC 90

SELC 100

SELC 110

SELC 120

SELC 130

SELC 1.10

SELC 150

SELC 160

SELC 170

SFI.S. $1 B Q$

SELC 190

SELC 2ED

SELC .210

SELC 220

SELC 230

SELC 240

SFIS $P 50$

SELC. 260

SELC 270

SELC . 280

SELC 290

SELC 3EB

SELC 310

SELC 32B

SELC 33E

SELC 340

SELC 350

SELC 360

SELC 370

SELC 380

SELC 398

SELC $4 E O$

SELC 410 
h. ASSM Job Control Language: Execution

ASSM has been compiled using S/360 FORTRAN IV (H) with OPT $=02$.

It's currently running on an IBM S/360 50-75 using OS MVT Release 20 under ASP.

The following JCL represents the use of the system facilities that ASSM could possibly require. It is the JCL used for the Chicago region sarmle problem. [Note: IAPERT $=1$ requires FT07F001 and IPUNCH $=20$ requires FT20F001.]

\begin{tabular}{|l|}
\hline$/ 1$ \\
$/ /$ \\
\hline
\end{tabular}




\section{Input Description}

All input to the ASSM program uses the NAMELIST format. The following restrictions apply to each of the records (cards) in the input data sets (file or card deck).

- The first character (column) in each record (card) must be blank.

- The second character (column) in the first record (card) must be an $\mathcal{G}$, immediately followed by the NAMELIS"I name, E.g. , EINDATA or EINSORC.

- This name is followed by data items separated by commas. The form of the data itcm is:

$$
\underline{\text { VARTABLE NAME }=\text { CONSTANT }(S)}
$$

The end of the data group is signaled by an GEND.

- Only names in the Clossary* can be input. They must appear exactly as shown, and there must be no. embedded blanks. Only variables whose values need be assigned or changed should appear in the data group.

- There should be no blanks between the end of a constant and the comma. That is, all constants must be right justified. The constants should be of the same typc as the in-

*See Sec. 3 of this appendix. 
put variable. (Three types of constants are considered, namely

alphameric - characters encloscd by single quotation marks, integer - numeric value without a decimal point, and

rea 1 - numeric value with a decimal point.)

The number of constants in the list must be less than or equal to the number of elements in the array.

- With the exception of the first character (column) of each record (card), data items may appear anywhere in the record (card).

Input to ASSM is composed of two separate, but complementary, data sets (file). One is composed primarily of control parameters and meteorological data, and is input from logical unit.5 (card reader) through the NAMELIST name INDATA. The other contains regional source data and is input from logical unit 10 through the NAMELIST name INSORC. NAMELIST INDATA is considered first. Its deck structure is displayed in Figure B-2. Whenever possible, examples will reference the input and output for the sample problem. Thus, it would be advantageous to consult Figure B-3, the completed input form for the sample problem. 


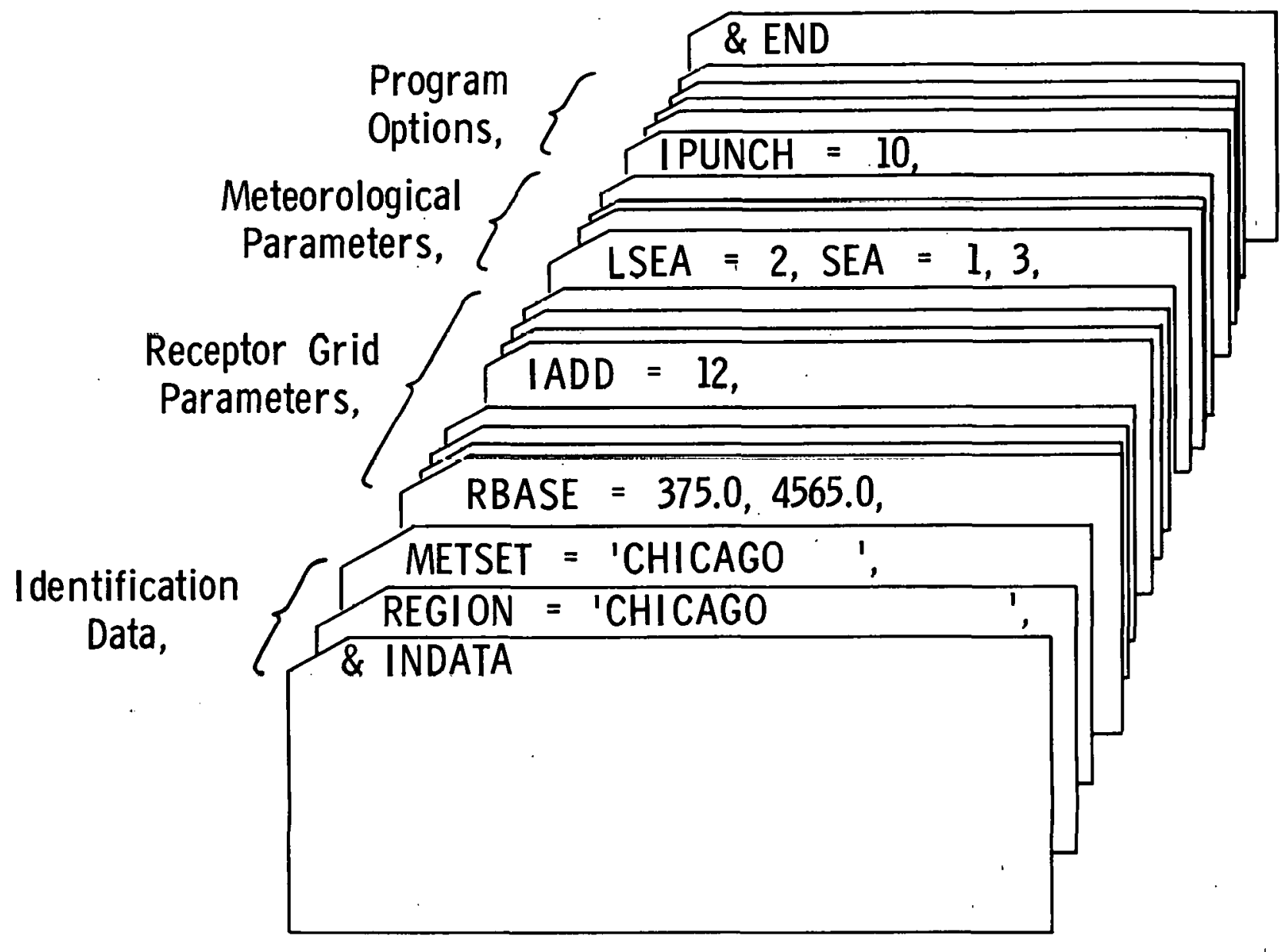

Fig. B-2. ASSM Card Input Deck 


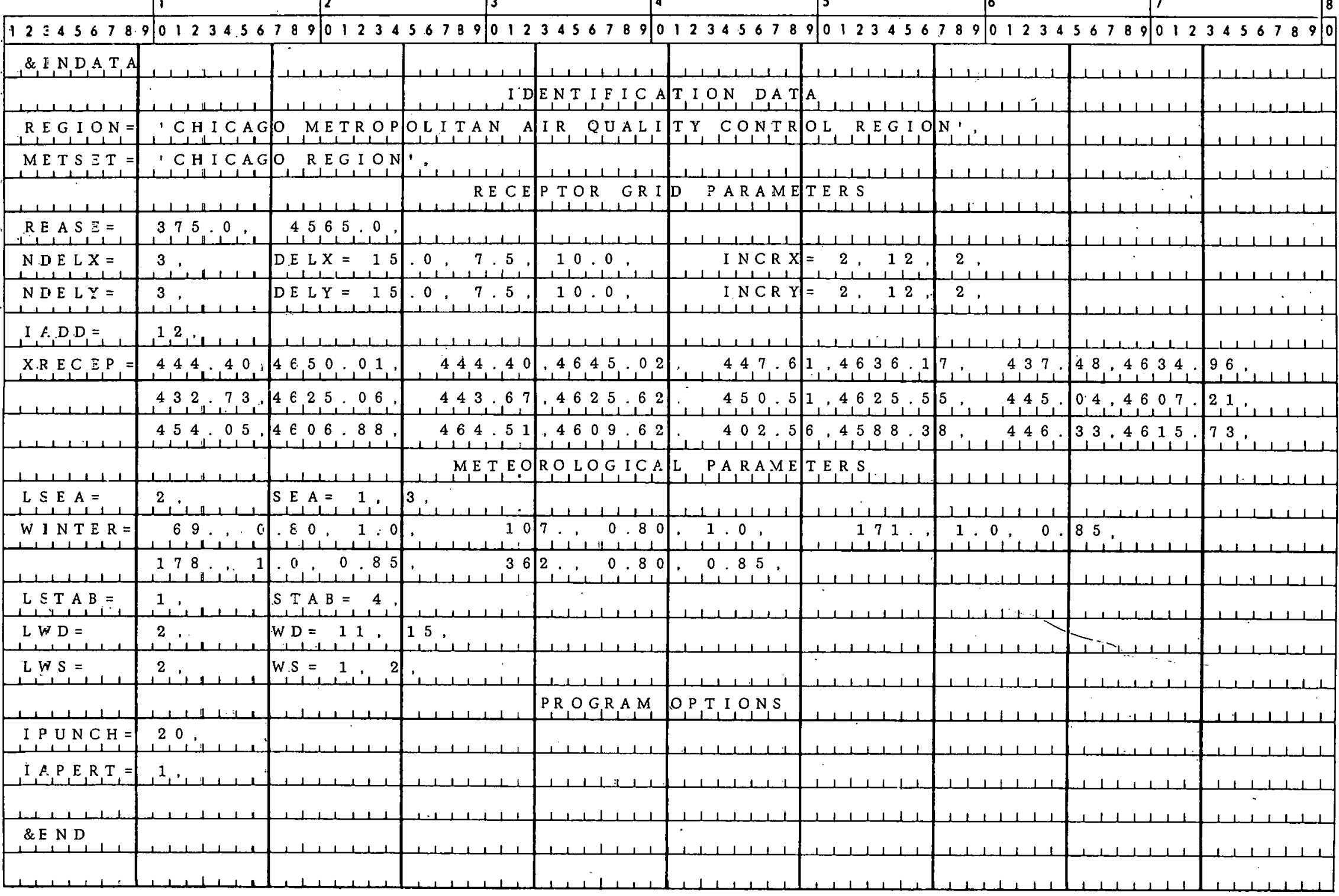


a. Identification Data

\begin{tabular}{|c|c|c|}
\hline Parameter & Type & Description \\
\hline REGION & Alphameric & $\begin{array}{l}\text { Identifying information, of at most } 72 \\
\text { characters enclosed in single quote marks, } \\
\text { used as the primary title for all printed } \\
\text { output. [Default* is all blanks] }\end{array}$ \\
\hline METSET & Alphameric & $\begin{array}{l}\text { Identifying information, of at most } 16 \\
\text { characters enclosed in single quote marks, } \\
\text { used as part of a label that appears on all } \\
\text { output from the ASSM system. This "label" } \\
\text { functions as a cross-reference for all out- } \\
\text { put. [Default is all blanks] }\end{array}$ \\
\hline
\end{tabular}

* "Default" refers to value(s) assigned if variable is omitted from input. 
b. Receptor-grid Parameters*

\begin{tabular}{|c|c|c|}
\hline Parameter & Type & Description \\
\hline RBASE & Real & $\begin{array}{l}\text { (horizontal) and } y \text { (vertical) coordinates, } \\
\text { in kilometers, of the receptor grid origin. } \\
\text { E.g. , if the origin is }(375,4565) \text {, then } \\
\text { RBASE }=375.0,4565.0 \\
\text { [Default is }(0.0,0.0)]\end{array}$ \\
\hline DELTA & Real & $\begin{array}{l}\text { Control parameter for the receptor grid type. } \\
\text { If DELTA >0, a uniform grid is, used } \\
\text { and 'DELTA' is the spacing (kilometers) } \\
\text { between consecutive grid points in } \\
\text { both the X- and } y \text { - directions. } \\
\text { If DELTA is } 0 \text { or omitted, a variable } \\
\text { spacing in either one or both dir- } \\
\text { ections (non-uniform grid) is used. } \\
\text { E.g., in the sample problem a non-uniform } \\
\text { grid was used and DELTA was- omitted. If a } \\
\text { uniform grid was desired, then DELTA = } 12.5 \\
\text { could be used. } \\
\text { [Default is } 0 \text { ] }\end{array}$ \\
\hline
\end{tabular}

*Examples refer to the receptor grid displayed in Figure B-4. (Sample i problem grid) 


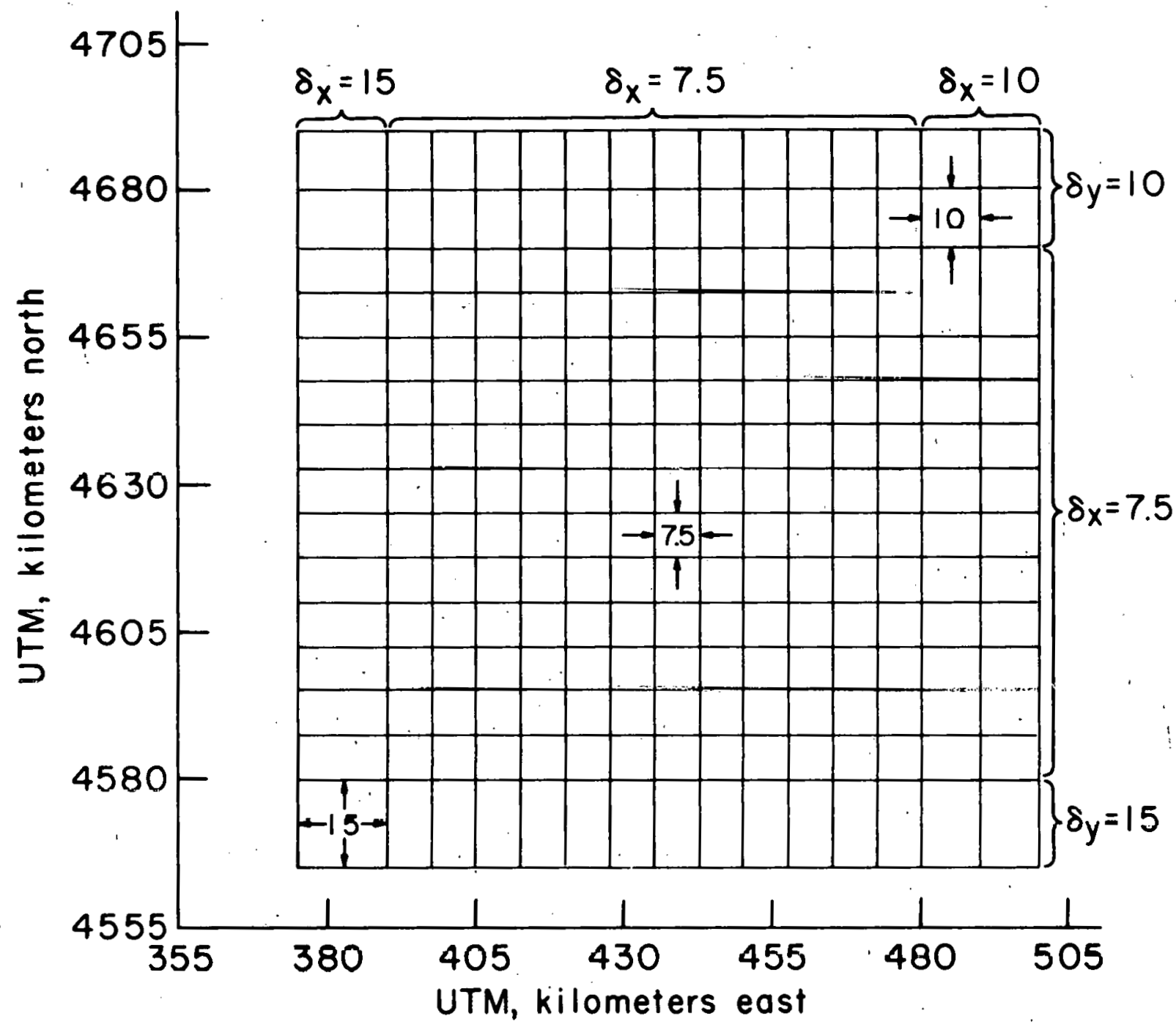

Fig. B-4. Chicago Region Receptor Grid 
If a uniform grid is used, then omit the next four variables.

NDELX Integer

Number of sections $(<3)$ in the $x$-direction of the receptor grid. E.g., the grid in the sample problem has 3 sections, NDELX $=3$. [Default is 1]

NDELY

Integer

Similar to NDELX but for the $y$-direction. $(\leq 3)$.

[Default is 1]

DELX Real

Spacing (kilometers) between consecutive

columns (mesh size) for each horizontal section of the grid. There must be NDELX such values. E.g., for the three horizontal sections of the sample grid, DELX $=15.0$, $7.5,10.0$.

DELY

Real

Similar to DELX but for the $y$-direction. 
For uniform grid, INCRX is the number of columns in the $x$-direction. E.g., for the grid of width 125 kilometers and DELTA $=12.5$, then INCRX $=11$

For non-uniform grid, INCRX is a list of the number of columns in the $K$ uniform sections $\left(1^{\prime} \leq K \leq 3\right)$ of the grid in the $X$-direction. In the 2nd and 3rd sections, the leftmost (shared) colum is not counted. E. g., for the grid of the sample problem with NDELX $=3$ and DELX $=15.0,7.5,10.0$, then $\operatorname{INCRX}=2,12,2$

INCRY

Integer Similar to INCRX but for the $y$-direction.

NOTE: The grid is defined independently in each direction. That is, the spacing in the horizontal direction need not correspond to that in the vertical direction.

IADD

XRECEP

Integer

Number of non/grid receptors.

[Default is zero]

Real

$X$ and $y$ coordinates (kilometers) of the nongrid receptors. There must be IADD such coordinate pairs. E.g., In the same problem 12 such pairs are included.

NOTE: The total number of receptor locations (grid + non-grid) must not exceed 340 . For the sample problem there are 268 receptor locations.

$$
\left.\begin{array}{l}
\left.\begin{array}{l}
\text { grid } \\
\begin{array}{l}
\text { : } 12+2+2 \\
y:
\end{array} \\
\text { non-grid }
\end{array}\right\} 16 \times 2+2
\end{array}\right\} \begin{array}{r}
256 \\
\frac{12}{268}
\end{array}
$$


c. Meteorological Parameters*

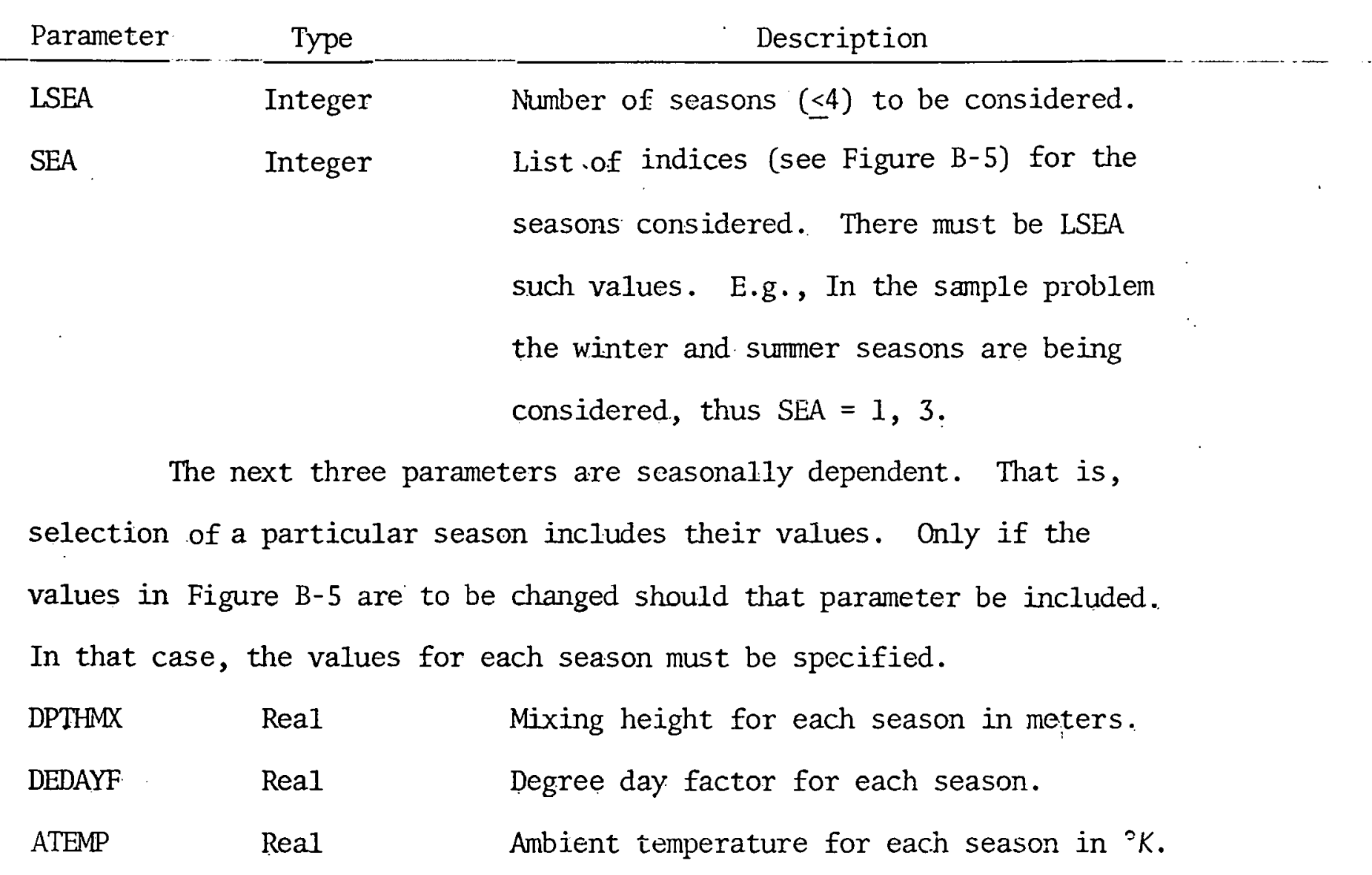

*Table B-1 contains the default meteorological data for $\Lambda$ SSM. 
TABLE B-1. Defarit Meteorological Data

\begin{tabular}{|c|c|c|c|c|c|c|c|c|}
\hline \multirow[b]{2}{*}{ Number } & \multirow{2}{*}{$\begin{array}{c}\text { Wind } \\
\text { Direction }\end{array}$} & \multirow{2}{*}{$\begin{array}{l}\text { Wind Spred } \\
\text { (Knots) }\end{array}$} & \multirow{2}{*}{$\begin{array}{l}\text { Stability } \\
\text { Class }\end{array}$} & \multirow[b]{2}{*}{ Season } & \multirow{2}{*}{$\begin{array}{l}\text { Mixing Height } \\
\text { (Meters) }\end{array}$} & \multirow{2}{*}{$\begin{array}{l}\text { Degree Day } \\
\text { Factor }\end{array}$} & \multicolumn{2}{|c|}{ Temperature } \\
\hline & & & & & & & $\left({ }^{\circ} \mathrm{K}\right)$ & $\left({ }^{\circ} \mathrm{F}\right)$ \\
\hline 1. & $\mathrm{~N}$ & $0-\overline{3}$ & Unstable & $\begin{array}{l}\text { Dec-Feb } \\
\text { (Winter) }\end{array}$ & 600 & 2.16 & 271.89 & 30 \\
\hline 2 & NNE & $4-6$ & $\begin{array}{l}\text { Moderately } \\
\text { Unstable }\end{array}$ & $\begin{array}{l}\text { Mar-May } \\
\text { (Spring) }\end{array}$ & 850 & 1.0 & 283.00 & 50 \\
\hline 3 & NE & $7-10$ & $\begin{array}{l}\text { Slightly } \\
\text { Unstable }\end{array}$ & $\begin{array}{l}\text { Jun-Aug } \\
\text { (Summer) }\end{array}$ & 1100 & 0.04 & 296.89 & 75 \\
\hline 4 & ENE & $11-16$ & Neutral & $\begin{array}{l}\text { Sept-Nov } \\
\text { (Fa11) }\end{array}$ & 850 & 0.8 & 283.00 & 50 \\
\hline 5 & $\mathrm{E}$ & $17-21$ & Stable. & & & & & \\
\hline 6 & ESE & over 21 & & , & & & & \\
\hline 7 & SE & & & & & & & \\
\hline 8 & SSE & & & & & & & \\
\hline 9 & S & & , & & & & & \\
\hline 10 & SSW & & & & & & & \\
\hline 11 & SW & & & & & & & \\
\hline 12 & WSW & & & . & ' & & & \\
\hline 13 & W. & & & & & & & . \\
\hline 14 & WNW & & & & & & & \\
\hline 15 & NW & & & & & & & \\
\hline 16 & $\mathrm{NNW}$ & & & & ' & & & \\
\hline
\end{tabular}


It is possible to seasonally adjust the annual average emission rates of $\mathrm{SO}_{2}$ and/or particulates for a selected set of solirces. The following parametcrs perform this function.

WINTER

Real

List of triples specifying the source identifier and the emission rate adjustment factors for that source for the winter season only. For each source being modified, the first value is the source identification number (its input position in the regional - source file*), the second value is the adjustment factor for $\mathrm{SO}_{2}$, and the last is the adjustment factor for particulates. No ordering of the sources being modified is assumed. E.g., in the sample problem five sources are being modified. In the first of these, source number 69 , the $\mathrm{SO}_{2}$ rate is being reduced by $20 \%$ while the particulate value is not to be changed. Thus, input is:

WINTER $=69 ., 0.80,1.0$

${ }^{*}$ See the description of SORCE, p. 145. 


\begin{tabular}{|c|c|c|}
\hline SPRING & Real & $\begin{array}{l}\text { Similar to WINTER but for the spring sea- } \\
\text { son only. }\end{array}$ \\
\hline SUMMER & Real & $\begin{array}{l}\text { Similar to WINTER but for the summer sea- } \\
\text { son only. }\end{array}$ \\
\hline FALL & Real & $\begin{array}{l}\text { Similar to WINTER but for the fall season } \\
\text { only. }\end{array}$ \\
\hline
\end{tabular}

For the seasonal adjustment factors, each source that appears in the regional source file may be adjusted. If a source is selected, adjustment factors for both $\mathrm{SO}_{2}$ and particulate must be input. Adjustments are always made to the emission rates in the input source file, regardless of what may have occurred for some other season. In the sample problem five sources will be modified for calculations of the winter season but the emission rates will revert back to their input values for calculations of the summer season.

\begin{tabular}{|c|c|c|}
\hline LSTAB & Integer & $\begin{array}{l}\text { Number of stability classes }(\leq 5) \text { to be } \\
\text { considered. }\end{array}$ \\
\hline STAB & Integer & $\begin{array}{l}\text { Lisl of indices (see Table B-1) for the } \\
\text { stability classes considered. There must } \\
\text { be LTSAB such values. E.g., in sample } \\
\text { problem the stability class is. neutral, } \\
\text { STAB }=4\end{array}$ \\
\hline LWD & Integer & $\begin{array}{l}\text { Number of wind directions }(\leq 16) \text { to be con- } \\
\text { sidered. }\end{array}$ \\
\hline WD & Integer & $\begin{array}{l}\text { List of indices (see Table B-1) for the wind } \\
\text { directions considered. 'Ihere must be LWD } \\
\text { such values. E.g., for a SW and NV wind, } \\
\qquad W D=11,15\end{array}$ \\
\hline
\end{tabular}


LWS

WS

Number of wind speeds $(\leq 6)$ to be considered. List of indices (see Table B-1) for the wind speeds considered. There must be LWS such values. E.g., for wind speeds of $0-3$ knots and 4 - 6 knots,

$$
\text { WS }=1,2
$$

The total number of meteorological sets that are considered in a given run is simply the product of LSEA $x$ LSTAB $\times$ LWD $\times$ LWS. For the sample problem, eight $(2 \times 1 \times 2 \times 2)$ meteorological sets were considered. 


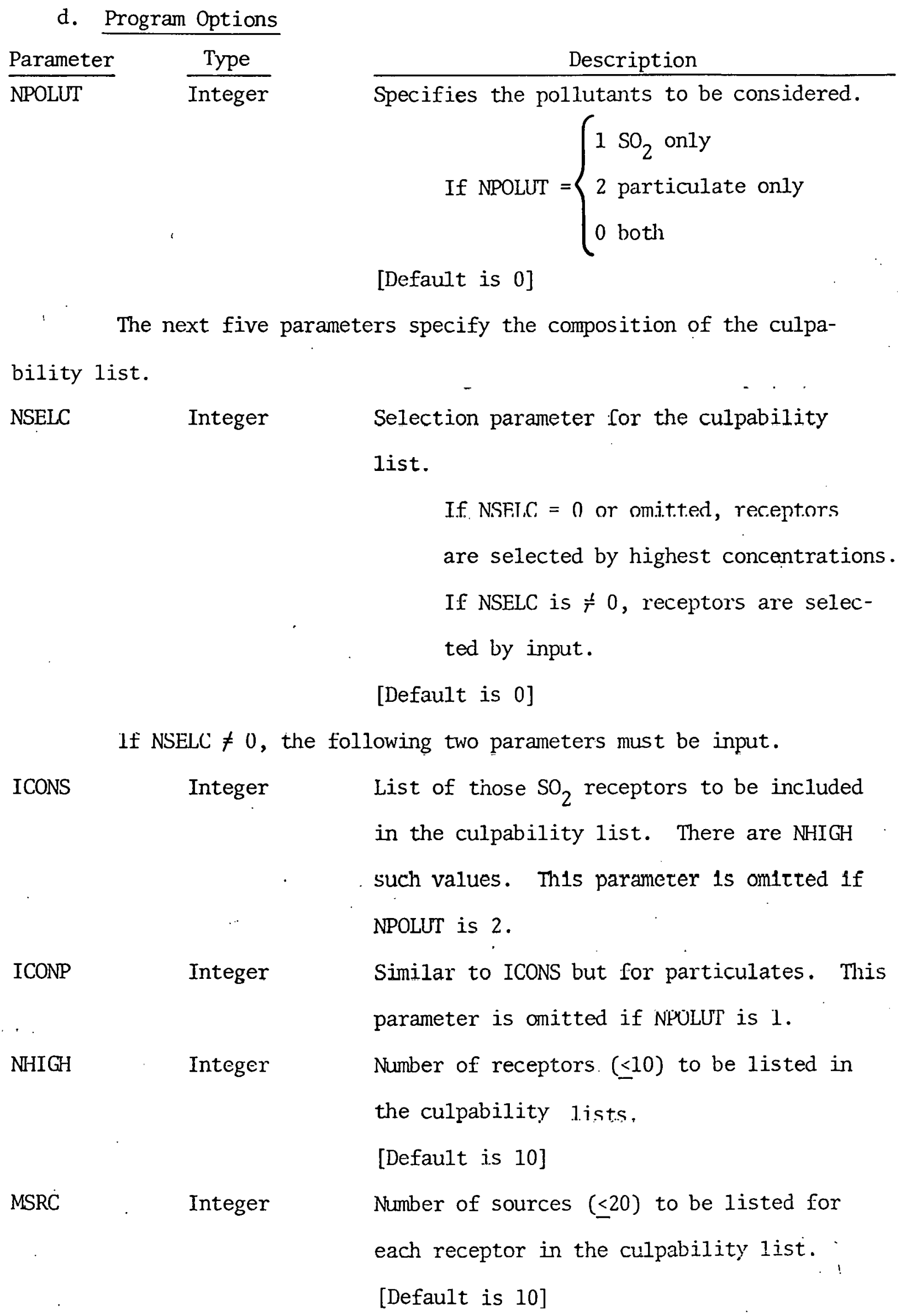

The next five parameters specify the composition of the culpability list.

NSELC

Integer

Selection parameter for the culpability list.

If. NSFIIC $=0$ or omit.ted, receptors are selected by highest concentrations. If NSELC is $\frac{t}{t} 0$, receptors are selected by input.

[Default is 0]

If NSELC $\neq 0$, the following two parameters must be input. ICONS Integer List of those $\mathrm{SO}_{2}$ receptors to be included in the culpability 1ist. There are NHIGH such values. This parameter is omitted if NPOLUT is 2 .

ICONP Integer Similar to ICONS but for particulates. This parameter is omitted if NPOLUT is 1 .

NHIGH Integer Number of receptors. $(\leq 10)$ to be listed in the culpability list.s, [Default is 10] MSRC . Integer Number of sources $(\leq 20)$ to be listed for each receptor in the culpability 1 ist. [Default is 10] 
In the sample problem, defaults were assumed for the culpability list parameters. The culpability list is thus composed of the 10 highest source contributors to the 10 highest receptors in the region.

BACKGR

Real

Background concentration for $\mathrm{SO}_{2}$ and particulates in micrograms per cubic meter. If BACKGR is included, both values must be specified.

[Default is 1.0 for both]

RCFR

Real

Residential/commercial fraction for area sources.

[Default is 0.45]

The next two parameters control additional output.

IPUNCH Integer

Control parameter for output of receptor coordinates and concentrations, and

"selected" receptors.

If IPUNCH $>0$, the values are output onto logical unit IPUNCH in card image format.* If punched cards are desired then IPUNCH $=7$. The data output onto unit IPUNCH is designed for plotting using the SYMAP -2280 display program described in Appendix C. If IPUNCH is 0 or omitted, no output of receptor and culpability lata occurs. E.g., in the sample problem, output to unit 20 was requested by IPUNNCH $=20$ [Defaut is 0]

*Exact format is described in Table B-2. 
TABLE B-2. Description of LABEL Identifier

\begin{tabular}{|c|c|c|c|}
\hline Position & Variable & Codes & Values' \\
\hline $1-16$ & Metset & & Input, characters, p. 132 \\
\hline \multirow[t]{2}{*}{$17-19$} & Pollutant Type & $\mathrm{SO}_{2}$ & $\mathrm{SO}_{2}$ \\
\hline & & PRT & Particulate \\
\hline \multirow[t]{4}{*}{21} & Season & $\mathrm{H}$ & Winter (heating) Dec-Feb \\
\hline & & S & Spring Mar-May \\
\hline & & $\mathrm{N}$ & Summer (non-heating) June-Aug \\
\hline & & $\mathrm{F}$ & Fall Sept-Nov \\
\hline \multirow[t]{5}{*}{$23-24$} & Stability Class & VU & 1: very unstable \\
\hline & & MU & 2: moderately unstable \\
\hline & & SU & 3: slightly unstable \\
\hline & & NT & 4: neutral \\
\hline & & ST & 5: stable \\
\hline $26-28$ & Wind Direction & See Table B-1 & See Table B-1 \\
\hline \multirow[t]{6}{*}{$30-31$} & Wind Speed & 3 & $0-3$ knnt.s \\
\hline & & 6 & 4-6 knots \\
\hline & & 10 & 7-10 knots \\
\hline & & 16 & $11-16$ knots \\
\hline & & 21 & 17-21 knots \\
\hline & & 25 & over 21 knots \\
\hline $33-35$ & Case Number & & \\
\hline
\end{tabular}




\begin{tabular}{|c|c|c|}
\hline IAPERT & Ințeger & $\begin{array}{l}\text { Control parameter for punching (unit } 7 \text { ) } \\
\text { cards containing a cross-referencing label } \\
\text { for each meteorological set considered. } \\
\text { If IAPERT } \neq 0 \text {, cards are punched. } \\
\text { If IAPERT is } 0 \text {, no cards are punched. } \\
\text { [Default is } 0 \text { ] }\end{array}$ \\
\hline NCASE & Integer & $\begin{array}{l}\text { As the meteorological sets are considered } \\
\text { they are numbered for cross-referencing } \\
\text { output. NCASE is the initial value. } \\
\text { [Default is } 1 \text { ] }\end{array}$ \\
\hline
\end{tabular}

We will now consider NAMELIST INSORC. It contains four variables that describe the sources in a given region.

NSORCE

NCSORC

SORCE
Integer

Integer

Rea1
Number of sources $(\leq 1000)$ that are input.

Number of point sources in the region source

file. The first NCSORC are the point sources.

Array that defines the sources. There must

be NSORCE such sources: For each source

the following seven values must be input:

(1) $x$ - coordinate in kilometers,

(2) $y$ - coordinate in kilometers,

(3) area in square kilometers,

(4) annual average $\mathrm{SO}_{2}$ emission rate in tons/day,

(5) annual average particulate emission rate in tons/day,

(6) physical stack height in meters, and (7) SIC (Standard Industrial Classification) code. 
QSORCE

Real

Array defining the heat emission rate (BTU/day) for each source. There must be NSORCE such values.

Each element represents:

coal heat content (BTU/ton) $\mathrm{x}$ annual coal rate (tons/day)

oil heat content (BTU/gal) $\mathrm{x}$ annual

oil rate (gal/day)

gas heat content (BTU/cu.ft.) $x$ annual gas rate (cu.ft./day) 
3. Glossary of ASSM Input Variables

Name

Description

Page

ATEMP

Ambient temperature

BACKGR

Array containing the background concentrations

for $\mathrm{SO}_{2}$ and particulates

DEDAYF

Degree day factor

DELTA

Parámeter to select receptor grid type

DELX

Mesh size(s) for grid in $X$ - direction

135

DELY

Mesh size(s) for grid in $y$-direction

135

DPTHMX

Mixing height ,

FALL

Array containing the source number and the (FALL) seasonal adjustment factors for the $\mathrm{SO}_{2}$ and particulate emission rates of this source

IADD

Number of non-grid receptors

IAPERT

Control parameter for "aperture" cards

ICONP

Receptor numbers for those particulate receptors

selected for the culpability list

ICONS

Receptor numbers for those $\mathrm{SO}_{2}$ receptors selected

for the culpability list

INCRX

Number of columns ( $X$ - direction) in the receptor

grid

INCRY Number of rows ( $y$ - direction) in the receptor

grid

\&INDATA NAMELIST control card for the "parameter" file

EINSORC NAMELIST control card for the regional "source" file 
IPUNCH

Control parameter for outputing the receptor concentration data

LSEA

Number of seasons to be considered

LSTAB

Number of stability classes to be considered

MŚRC

Number of sources to be displayed for each

receptor in the culpability 1 ist

NCASE

Initial value for numbering the cases as they

are output

NCSORC Number of point sources in the regional. source

fille

NDELX Number of sections of the receptor grid in the $x$ - direction

NDELY Number of sections of the receptor grid in the $y$ - direction

NHIGH Number of receptors to be included in the culpability list

NPOLUT

Parameter indicating the pollutants to be considered

NSELC

Parameter indicating receptor selection for the culpability list 
$\underline{\text { Name }}$

Description

$\underline{\text { Page }}$

NSORCE

Number of sources in the regional source file

QSORCE

Array containing the heat emission rate for each

source

RBASE

Array containing the coordinates of the receptor grid origin

RCFR

Residential/commercial fraction for area sources

REGION

Identifying information for printed output

SEA

Array containing the seasonal indices

SORCE

Array containing the source location, area,

emission rates, and physical stack height for

each source

SPRING

Array containing the source number and the

(SPRING) seasonal adjustment factors for the

$\mathrm{SO}_{2}$ and particulate emission rates of this source

STAB

Array containing the stability-class indices

SUMMER

Array containing the source number and the (SUMMER)

seasonal adjustment factors for the $\mathrm{SO}_{2}$ and partic-

ulate emission rates of this source

WD

Array containing the wind direction

WINTER Array containing the source number and the (WINTJR)

seasonal adjustment factors for the $\mathrm{SO}_{2}$ and partic-

ulate emission rates of this source.

WS

Array containing the wind-speed indices

141

XRECEP

Locations of the non-grid receptors 
4. Output Description

The output for a complete case from the Chicago region sample problem is presented in Figure B-5. The printed output consists of two parts. The first is the receptor concentration data, and the second is the culpability lists. Each is headed by three lines of identifying information.

The first line contains a 'label' that serves as cross-referencing information for all output. It is composed of 35 characters and is described in Table B-2. This label is the output that is punched on cards iff IAPERT $=1$. The second line contains the characters input through the REGION variable (page 132). The third line is an enumeration of the coded data appearing in the 'label'.

a. Receptor Concentration Data

The principal output of the diffusion model is contained in the first part of Fig. B-5 (pages 153-159). Each grid and non-grid receptor is listed by receptor number, its location, and the ground-level concentration for each pollutant as "estimated" by the diffusion model. 
b. Culpability List

The contributions of each of the MSRC highest point and area sources in the region to NHIGH selected or highest receptors (specified in table heading) are presented in the second part of Fig. B-5 (pages 160-163).

For each source in the table, the source number (followed by an asterisk for area sources), the contribution of that source to this receptor both as a percentage of the total concentration at this receptor and as the actual concentration (micrograms/cubic meter), and the effective stack height of the source (meters) are listed. The last entry for each receptor contains the total concentration of the sources listed and their percentage of the total concentration (from all sources) at that receptor. One culpability list appears for each pollutant.

For example, in the culpability list for $\mathrm{SO}_{2}$ (page 160) receptor 266 has the highest estimated concentration of al1 receptors. Point source 69 is the highest contributor to this receptor. Its contribution was 362.92 micrograms/cubic meter, which represents $23.49 \%$ of the total concentration from all sources at receptor 266 . The ten sources listed contributed 1386.35 micrograms/cubic meter, which represents $89.74 \%$ of the total concentration from all sources at receptor 266.

c. Iospleth Plots

The data printed in the RECEPTOR CONCENTRATION TABLE is also optionally (IPUNCH) output for subsequent input into a plotting system. Such a system utilizing SYMAP and the IBM 2280 is described in Appendix C. Included in the output is a numeric code identifying the meteorological set (season, stability class, wind direction, and wind speed; see Table B-1 for interpretation of the values) and, also, the receptors appearing in the culpability lists for $\mathrm{SO}_{2}$ and particulates. 
(Note: The output occurs in MAIN, statements MAIN2240 through MAIN2510 and MAIN2560 through MAIN2580)

d. Aperture Cards

Optionally available (IAPERT) is the output of cards containing the LABEL as described in Table B-2. These cards have proven useful for duplicating onto aperture cards containing the $35 \mathrm{~mm}$ film displays of the isopleths. The cards output from the sample problem of the Chicago region appear in Figure B-6. 


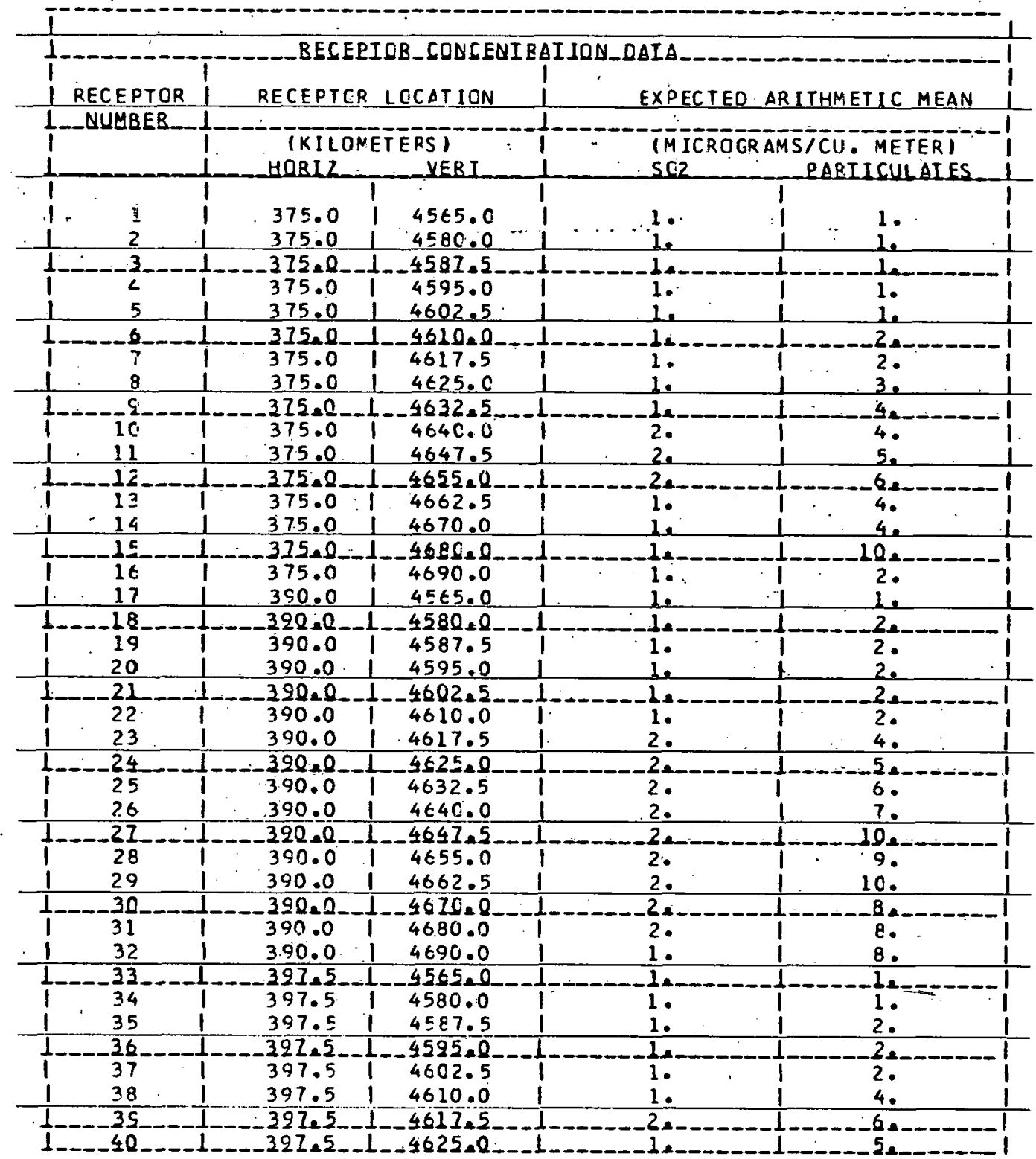

Fig. B-5. Printed Output from the Sample Problem 


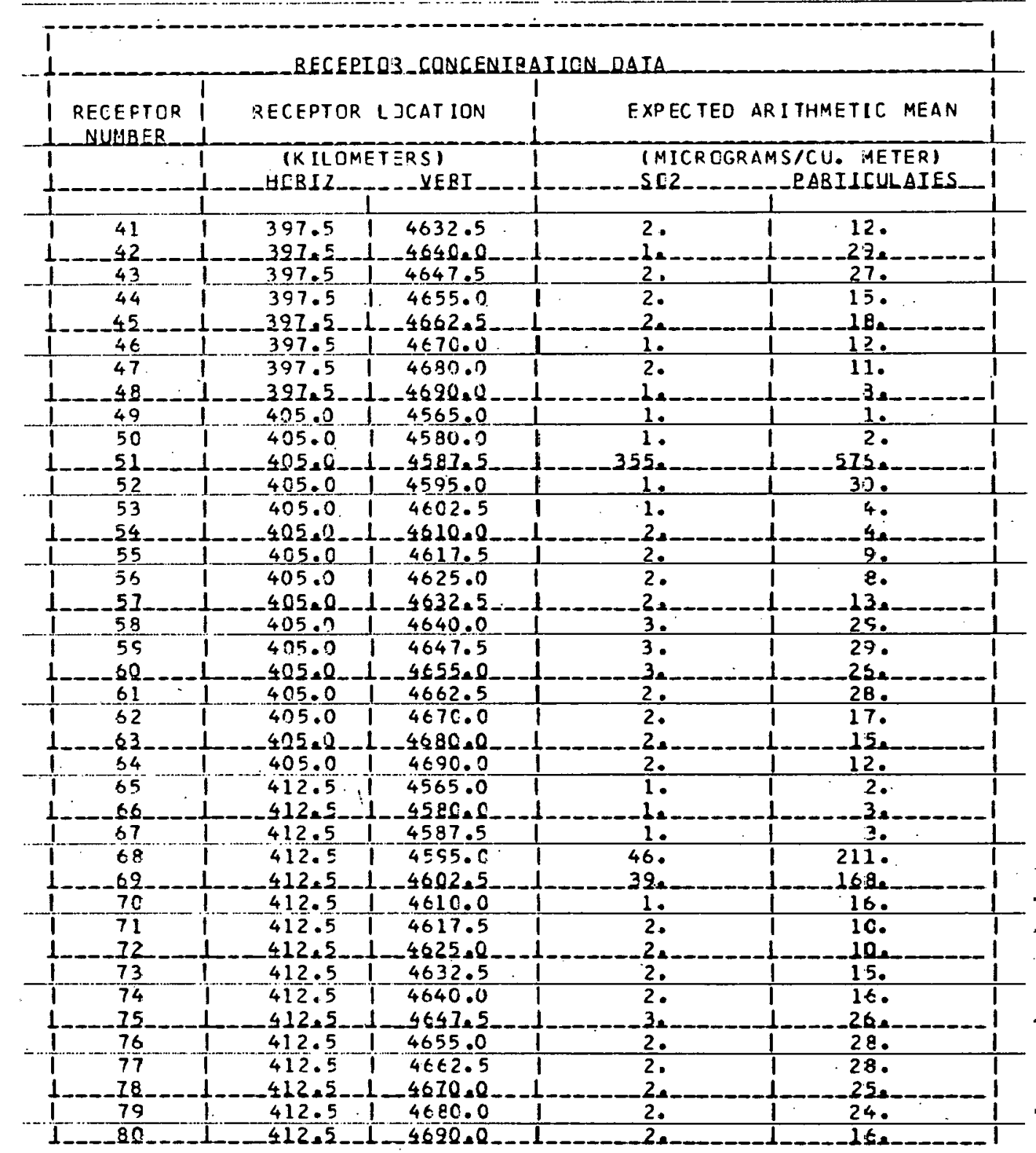

Fig. B-5 (Contd.) 


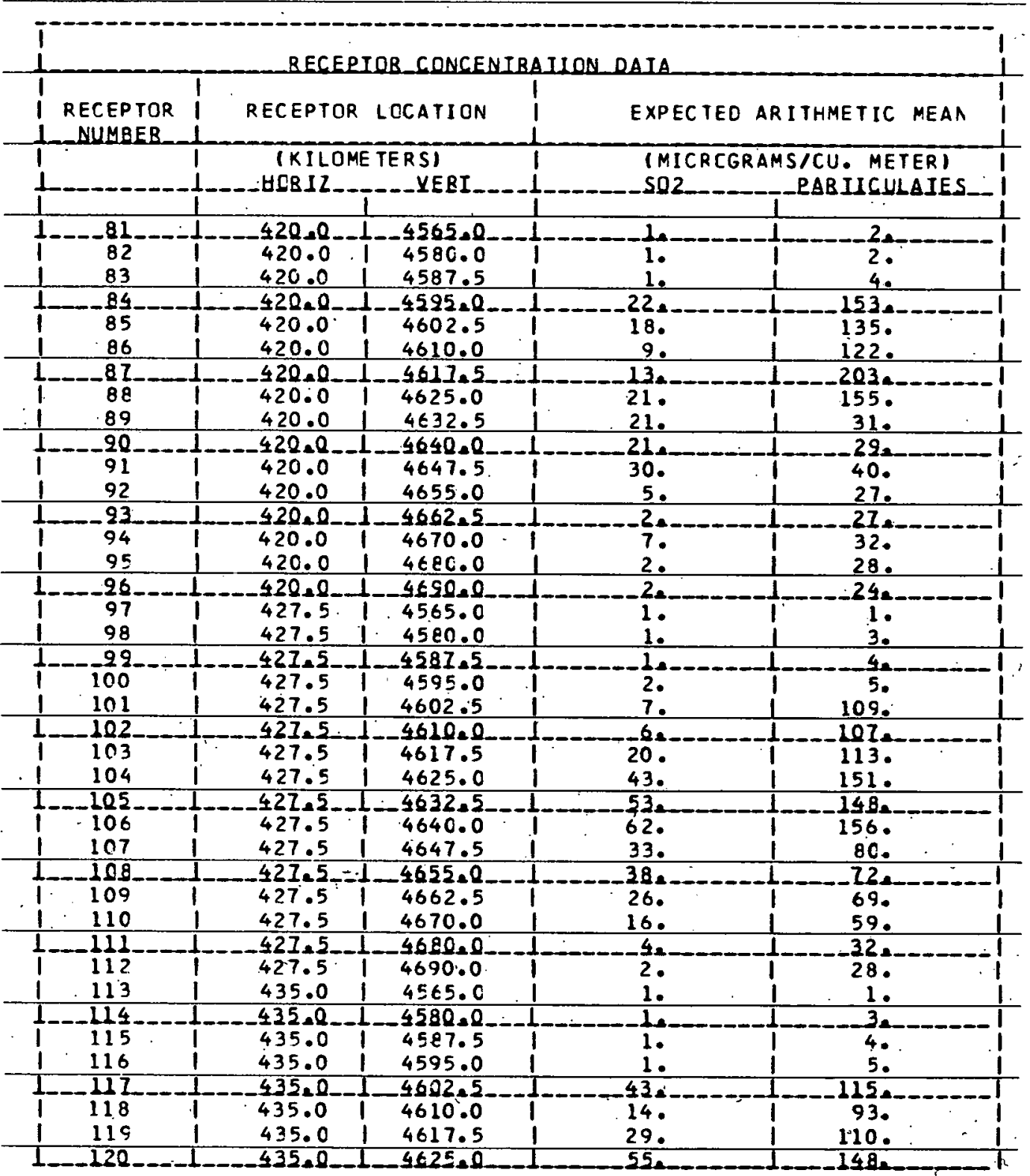




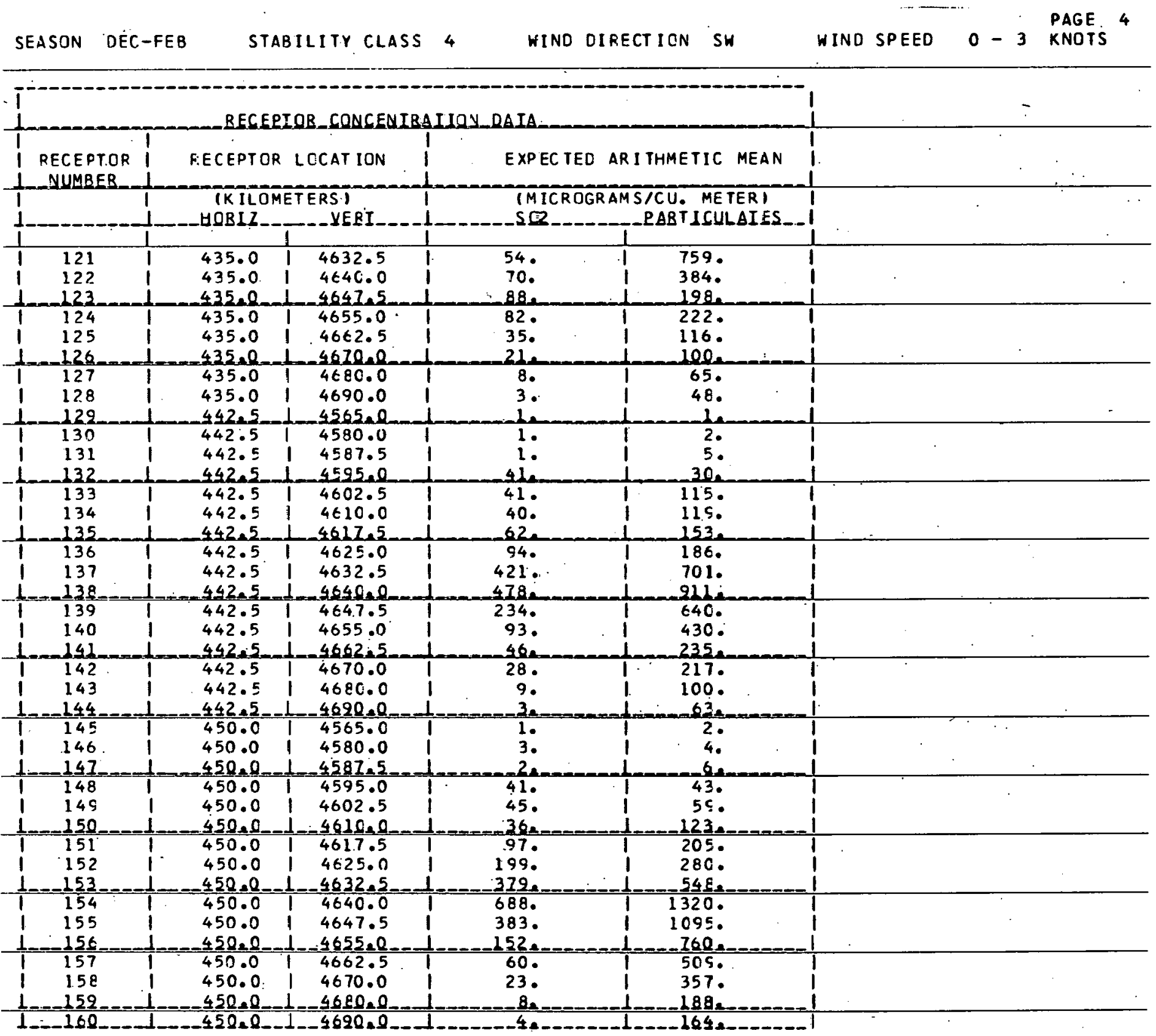

Fig. B-5 (Contd.) 


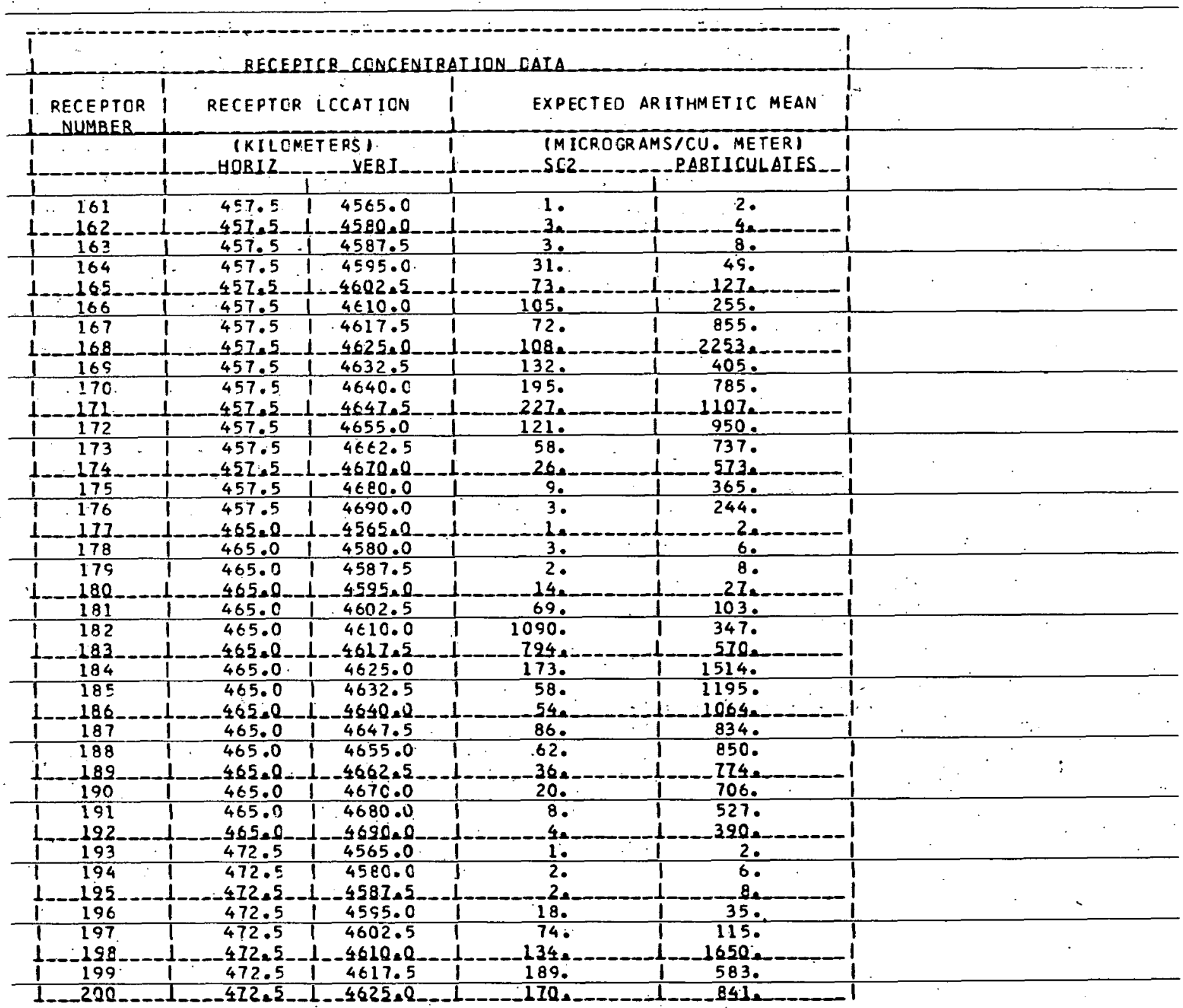

.. Fig. B-5 (Contd.) 


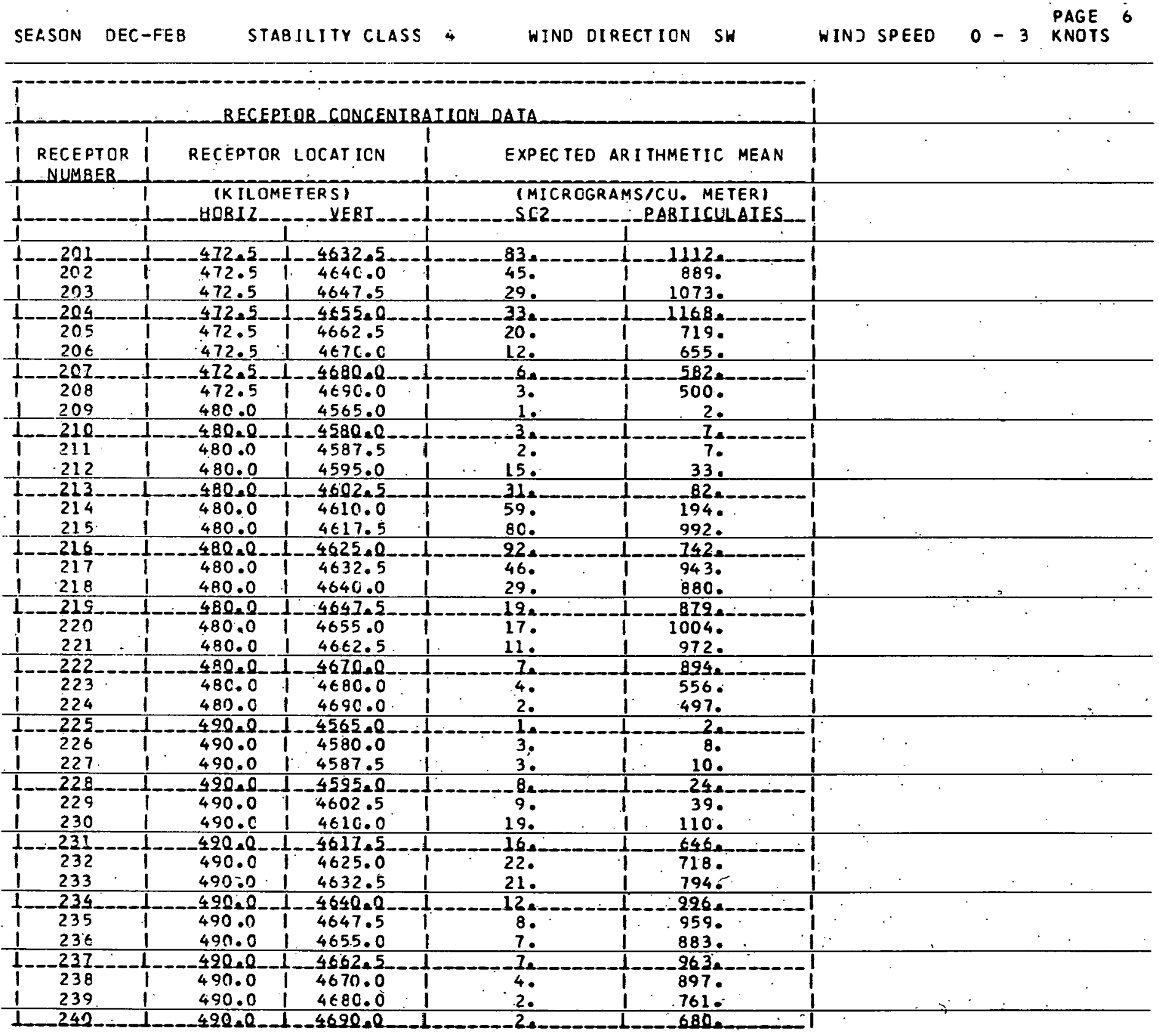

Fig. B-5 (Contd.) 


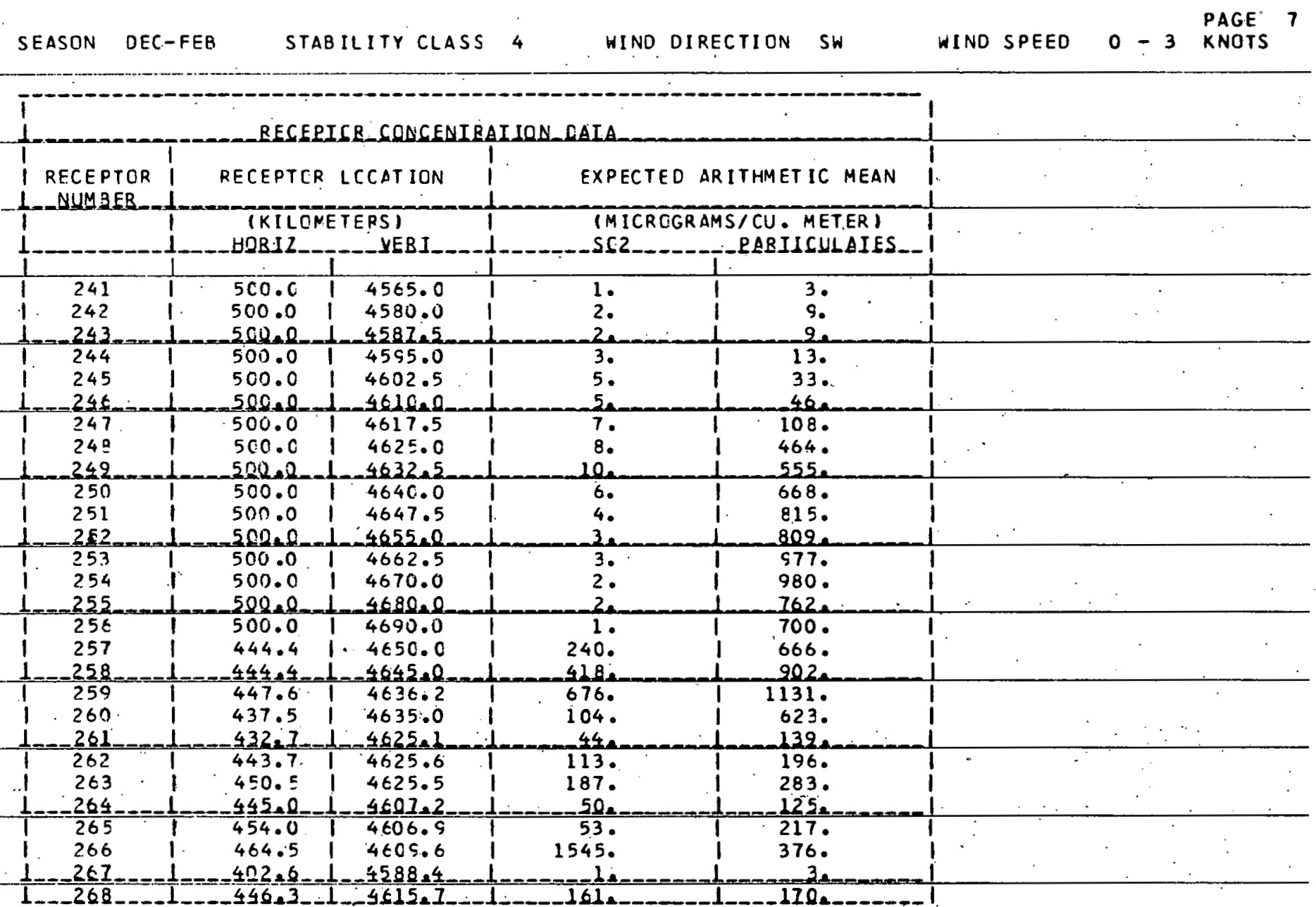

Fig. B-5 (Contd.) 
CHICAGO METROPOLIIAN AIR QUALITY CCNIRCL REGICA
SEASON DEC-FEB
STABILITY CLASS 4
HINC DIRECTION SW
WINO SPEED
$0-3$ rnOTS

SO2 FOR HIGHEST RECEPTORS. I MICROGRAMS PER CUBIC METER I

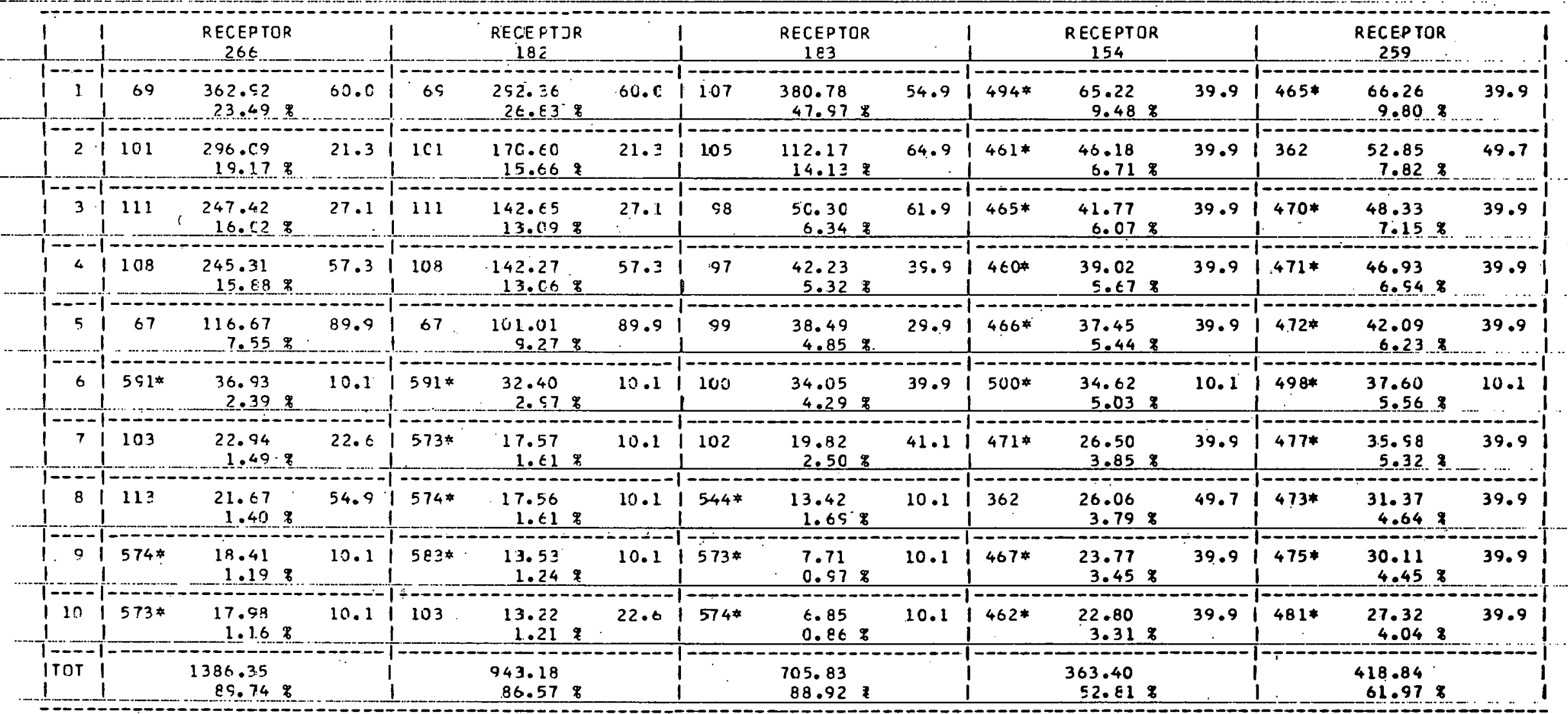

Fig. B=5 (Contd.) 
CHICAGQ METRCPOLITAR AIR GUALITY CONIROL REGION
SFASDN DEC-FER
STABILITY CLASS 4
WIND OIRECTION SW
WIND SPEED
0 - 3 KNOTS

SO2 FOR HIGHEST RECEPTORS I MICROGRAMS PER CUBIC METER )

\begin{tabular}{|c|c|c|c|c|c|c|c|c|c|c|c|c|c|c|c|}
\hline 1 & & $\begin{array}{c}\text { RECE PT QR } \\
138\end{array}$ & & 1 & $\begin{array}{l}\text { RECEPTOR } \\
137\end{array}$ & 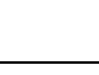 & 1 & $\begin{array}{c}\text { RECEP TOR } \\
258\end{array}$ & & 1 & $\begin{array}{c}\text { RECE P TOR } \\
155\end{array}$ & & 1 & $\begin{array}{c}\text { RECEPT OR } \\
153\end{array}$ & \\
\hline $\begin{array}{r}11 \\
\end{array}$ & 362 & $\begin{array}{l}61.83 \\
12.94:\end{array}$ & $\begin{array}{r}49.7 \\
\end{array}$ & $\begin{array}{l}1362 \\
1 \\
\end{array}$ & $\begin{array}{r}179.70 \\
42.71 \%\end{array}$ & 49.7 & $\begin{array}{l}1494 * \\
\end{array}$ & $\begin{array}{l}66.53 \\
15.92 .8\end{array}$ & 39.9 & $451 *$ & $\begin{array}{l}48.20 \\
12.59\end{array}$ & 10.1 & $500 *$ & $\begin{array}{l}62.89 \\
16.60\end{array}$ & 10.1 \\
\hline $\mid$\begin{tabular}{r|}
2 \\
1
\end{tabular} & $463 *$ & $\begin{array}{l}56.02 \\
11.73 \%\end{array}$ & 39.9. & $1498 *$ & $\begin{array}{l}56.86 \\
13.51 \%\end{array}$ & 10.1 & $1491 *$ & $\begin{array}{l}53.49 \\
12.80 \% \\
\end{array}$ & 10.1 & 1494 & $\begin{array}{l}40.76 \\
10.65\end{array}$ & 39.9 & $\begin{array}{l}505 * \\
\end{array}$ & $\begin{array}{l}43.32 \\
11.43 .8\end{array}$ & 10.1 \\
\hline $\begin{array}{l}3 \\
1\end{array}$ & 494 & $\begin{array}{r}54.13 \\
11.33 \mathrm{~g}\end{array}$ & 35.9 & $502 *$ & $\begin{array}{r}27.85 \\
6.62 \% \\
\end{array}$ & 10.1 & $492 *$ & $\begin{array}{r}38.86 \\
5.30 \%\end{array}$ & 10.1 & $1492 *$ & $\begin{array}{r}23.81 \\
6.22 \%\end{array}$ & 10.1 & 1486 & $\begin{array}{c}34.12 \\
9.01\end{array}$ & 39.9 \\
\hline $\begin{array}{l}1 \\
1 \\
1\end{array}$ & $496 *$ & $\begin{array}{r}41.22 \\
8.63 \\
-\end{array}$ & 10.1 & $484 *$ & $\begin{array}{r}20.82 \\
-4.55 \% \\
\end{array}$ & 35.9 & $1495 *$ & $\begin{array}{r}36.68 \\
8.78 \quad\end{array}$ & 10.1 & 529* & $\begin{array}{r}23.49 \\
6.14 \%\end{array}$ & 10.1 & $481 *$ & $\begin{array}{r}29.11 \\
7.68\end{array}$ & 39.9 \\
\hline $\begin{array}{ll}5 & 5 \\
1 & \end{array}$ & $498 *$ & $\begin{array}{r}40.84 \\
8.55\end{array}$ & 10.1 & 1482 & $\begin{array}{c}15.59 \\
4.66 ?\end{array}$ & 39.9 & $1496 *$ & $\begin{array}{r}28.85 \\
6.50\end{array}$ & 10.1 & $495 *$ & $\begin{array}{r}18.63 \\
4.878 \\
\end{array}$ & 10.1 & $480 *$ & $\begin{array}{r}26.10 \\
6.89\end{array}$ & 39.9 \\
\hline $\mid$\begin{tabular}{r|}
----1 \\
6
\end{tabular} & $495 *$ & $\begin{array}{r}33.20 \\
6.55 . \\
\end{array}$ & 10.1 & 1459 & $\begin{array}{c}15.80 \\
3.75\end{array}$ & 39.9 & 1362 & $\begin{array}{r}27.75 \\
6.64 \%\end{array}$ & 49.7 & $1461 *$ & $\begin{array}{r}17.45 \\
4.56 \%\end{array}$ & 39.9 & $488 *$ & $\begin{array}{c}23.37 \\
6.27\end{array}$ & 39.9 \\
\hline$\left\{\begin{array}{|}1---1 \\
1\end{array} \mid\right.$ & 469 & $\begin{array}{r}30.66 \\
6.42 .9 \\
\end{array}$ & 13.1 & $\left\{\begin{array}{l}1--1 \\
1490\end{array}\right.$ & $\begin{array}{r}15.75 \\
3.74 \%\end{array}$ & 10.1 & $1493 *$ & $\begin{array}{r}26.47 \\
6.33\end{array}$ & 10.1 & $460 \%$ & $\begin{array}{l}16.43 \\
4.25 \%\end{array}$ & 39.9 & $1--\cdots$ & $\begin{array}{r}19.34 \\
5.10\end{array}$ & 10.1 \\
\hline $\mid$ & $474 *$ & $\begin{array}{r}27.95 \\
5.85 \\
\end{array}$ & 10.1 & $I^{503 *}$ & $\begin{array}{r}14.47 \\
3.44 \% \\
\end{array}$ & 10.1 & $463 *$ & $\begin{array}{r}22.22 \\
5.32 \% \\
\end{array}$ & 35.9 & 466 & $\begin{array}{l}14.34 \\
3.75\end{array}$ & 39.9 & $501 *$ & $\begin{array}{l}18.74 \\
4.95\end{array}$ & 10.1 \\
\hline $\mid$\begin{tabular}{r|}
$\mid---1$ \\
1 \\
1
\end{tabular} & 4974 & $\begin{array}{r}27.93 \\
5.85 \% \\
\end{array}$ & 10.1 & $1507 *$ & $\begin{array}{r}13.75 \\
3.27 \% \\
\end{array}$ & 10.1 & $4.98 *$ & $\begin{array}{r}20.78 \\
4.97 \%\end{array}$ & 10.1 & $1493 *$ & $\begin{array}{r}13.45 \\
3.518\end{array}$ & 10.1 & $\mid \begin{array}{l}-0-1 \\
487\end{array}$ & $\begin{array}{r}16.29 \\
4.30\end{array}$ & 39.9 \\
\hline $\begin{array}{l}101 \\
1\end{array}$ & $464 *$ & $\begin{array}{r}25.70 \\
5.38 \\
\end{array}$ & 10.1 & $537 *$ & $\begin{array}{r}13.35 \\
2.17 \% \\
\end{array}$ & 10.1 & i 497 * & $\begin{array}{r}16.43 \\
3.93 \% \\
\end{array}$ & 10.1 & $1496 *$ & $\begin{array}{r}12.86 \\
3.36 \% \\
\end{array}$ & 10.1 & $502 *$ & $\begin{array}{l}16.25 \\
4.29\end{array}$ & 10.1 \\
\hline I & i & $\begin{array}{r}399.48 \\
83.61 \%\end{array}$ & & i & $\begin{array}{r}377.95 \\
85.82 \%\end{array}$ & & i & $\begin{array}{r}338.07 \\
80.88 \%\end{array}$ & & $i$ & $\begin{array}{r}229.43 \\
59.948\end{array}$ & & i & $\begin{array}{r}289.54 \\
76.41\end{array}$ & \\
\hline
\end{tabular}

Fig. B-5 (Contd.) 
CHICAGQ METROPOL ITAN AIR QUALITY CCNTRQL REGICA
SEASCN DEC-FEB
STABILITY CLASS 4
WIND DIRECT:ON SW
WI NO SPEED
c - 3
KAOTS PARTICULATES FOR HIGHEST RECEPTORS TMICZOGRANS PER CURIC METER I

\begin{tabular}{|c|c|c|c|c|c|c|c|c|c|c|c|c|c|c|c|}
\hline 1 & 1 & $\begin{array}{l}\text { RECEPTOR } \\
168 \\
\end{array}$ & . & 1 & $\begin{array}{l}\text { RECEP POR } \\
198\end{array}$ & 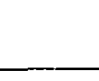 & I & $\begin{array}{c}\text { RECEPTCR } \\
184 \\
\end{array}$ & . & 1 & $\begin{array}{l}\text { RECEPTOR } \\
154\end{array}$ & 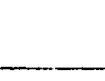 & 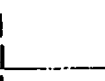 & $\begin{array}{c}\text { RECEP TOR } \\
185\end{array}$ & \\
\hline 1 & 171 & $\begin{array}{r}657.89 \\
29.20 \quad 8 \\
\end{array}$ & 52.1 & $\begin{array}{l}178 \\
1\end{array}$ & $\begin{array}{r}1394.64 \\
84.538\end{array}$ & 50.9 & 1171 & $\begin{array}{r}322.36 \\
21.25 \% \\
\end{array}$ & 52.1 & 362 & $\begin{array}{r}92.77 \\
7.03 \quad 6 \\
\end{array}$ & 49.7 & 171 & $\begin{array}{r}213.49 \\
17.868\end{array}$ & 52.1 \\
\hline 12 & 168 & $\begin{array}{r}429.70 \\
19.678\end{array}$ & 32.9 & 602 & $\begin{array}{r}25.86 \\
1.57 \\
\end{array}$ & 10.1 & 168. & $\begin{array}{r}210.55 \\
13.50 \%\end{array}$ & 32.9 & 494 & $\begin{array}{r}73.13 \\
5.54 \% \\
\end{array}$ & 39.9 & 168 & $\begin{array}{r}139.44 \\
11.67\end{array}$ & 32.9 \\
\hline 3 & $\begin{array}{l}169 \\
1\end{array}$ & $\begin{array}{r}393.65 \\
17.47 .5 \\
\end{array}$ & 52.1 & $603 *$ & $\begin{array}{l}24.63 \\
1.49 \% \\
\end{array}$ & 10.1 & 169 & $\begin{array}{r}152.89 \\
12.74 \quad \\
\end{array}$ & 52.1 & 1142 & $\begin{array}{r}70.78 \\
5.36 \quad \\
\end{array}$ & 16.2 & 169 & $\begin{array}{r}127.74 \\
10.69\end{array}$ & 52.1 \\
\hline $1^{---0}$ & 176 & $\begin{array}{r}149.88 \\
6.65 \% \\
\end{array}$ & 20.1 & $1556 *$ & $\begin{array}{r}20.99 \\
1.27 \% \\
\end{array}$ & 10.1 & 176 & $\begin{array}{r}54.79 \\
6.26 \% \\
\end{array}$ & $2 \mathrm{C} .1$ & $458 *$ & $\begin{array}{l}59.58 \\
4.52 \%\end{array}$ & 10.1 & 176 & $\begin{array}{r}69.31 \\
5.808\end{array}$ & 20.1 \\
\hline 5 & 160 & $\begin{array}{r}107.85 \\
4.798 \\
\end{array}$ & 52.1 & $591 *$ & $\begin{array}{r}18.23 \\
1.11 \% \\
\end{array}$ & 10.1 & $1 \in 0$ & $\begin{array}{r}67.82 \\
4.48 \% \\
\end{array}$ & 52.1 & 500 & $\begin{array}{r}57.36 \\
4.35 \% \\
\end{array}$ & 10.1 & 160 & $\begin{array}{r}49.46 \\
4.148\end{array}$ & 52.1 \\
\hline 6 & $505 *$ & $\begin{array}{r}54.55 \\
2.42 \quad \\
\end{array}$ & 10.1 & $599 *$ & $\begin{array}{r}11.44 \\
0.65 \% \\
\end{array}$ & 10.1 & $1 \in 4$ & $\begin{array}{r}54.39 \\
3.59 \% \\
\end{array}$ & 20.1 & $467 *$ & $\begin{array}{r}51.41 \\
3.30 \% \\
\end{array}$ & 39.9 & $500 *$ & $\begin{array}{r}44.90 \\
3.76 \quad 8\end{array}$ & 10.1 \\
\hline $\begin{array}{l}7 \\
1\end{array}$ & 274 & $\begin{array}{r}47.99 \\
2.138 \\
\end{array}$ & 52.1 & 1600 & $\begin{array}{c}10.54 \\
0.64 \\
\end{array}$ & 10.1 & 166 & $\begin{array}{r}50.25 \\
3.32 \% \\
\end{array}$ & $52 .-1$ & 145 & $\begin{array}{c}42.59 \\
3.23\end{array}$ & 3.0 & 164 & $\begin{array}{r}40.47 \\
3.39\end{array}$ & 20.1 \\
\hline $1^{1----}$ & 173 & $\begin{array}{l}43.18 \\
1.92 \%\end{array}$ & 52.1 & 616 & $\begin{array}{r}10.10 \\
0.61 \\
\end{array}$ & 10.1 & $1 \in 5$ & $\begin{array}{r}38.46 \\
2.54 \% \\
\end{array}$ & 35.1 & 260 & $\begin{array}{r}35.36 \\
2.08 \% \\
\end{array}$ & 19.8 & 166 & $\begin{array}{r}37.39 \\
3.13\end{array}$ & 52.1 \\
\hline 19 & $\begin{array}{l}363 \\
\end{array}$ & $\begin{array}{r}36.91 \\
1.64 \mathrm{z}\end{array}$ & 4.9 & $601 *$ & $\begin{array}{r}2.85 \\
0.54 \% \\
\end{array}$ & 10.1 & 544 & $\begin{array}{r}34.59 \\
2.28 \% \\
\end{array}$ & 10.1 & $461 *$ & $\begin{array}{r}34.59 \\
2.52 \%\end{array}$ & 39.9 & $505 *$ & $\begin{array}{r}34.29 \\
2.87 \%\end{array}$ & 10.1 \\
\hline 10 & $\begin{array}{l}1544 \% \\
1\end{array}$ & $\begin{array}{r}34.03 \\
1.51\end{array}$ & 10.1 & $\mid \begin{array}{l}607 * \\
\end{array}$ & $\begin{array}{l}7.79 \\
0.47 \div\end{array}$ & 10.1 & 363 & $\begin{array}{r}34.29 \\
2.26 \%\end{array}$ & 4.9 & $544 *$ & $\begin{array}{r}34.59 \\
2.028\end{array}$ & 10.1 & 363 & $\begin{array}{l}32.01 \\
2.68\end{array}$ & 4.9 \\
\hline$i^{\text {TOT }}$ & 1 & $\begin{array}{r}1955.63 \\
. \quad 86.81 \% \\
\end{array}$ & & $\begin{array}{l}1 \\
1\end{array}$ & $\begin{array}{r}1533.07 \\
92.92 \% \\
\end{array}$ & & 1 & $\begin{array}{r}1100.38 \\
72.67 \\
\end{array}$ & & i & $\begin{array}{r}552.26 \\
41.258 \\
\end{array}$ & & 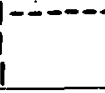 & $\begin{array}{r}788.49 \\
65.97 .5 \\
\end{array}$ & \\
\hline
\end{tabular}

Fig. B-5 (Contd.) 
CHICAGO METRCPOLITAK A IR GUAL ITY CONTROL REGION
SEASON DEC-FEE
STABILITY CLASS 4
WINC DIRECTION SW
WINO SPEED
$0-3$ KNOTS

PARTICULÄTES " FOR "HIGHEST RECEPTORS I MICROGRAMS PER CUBIC METER

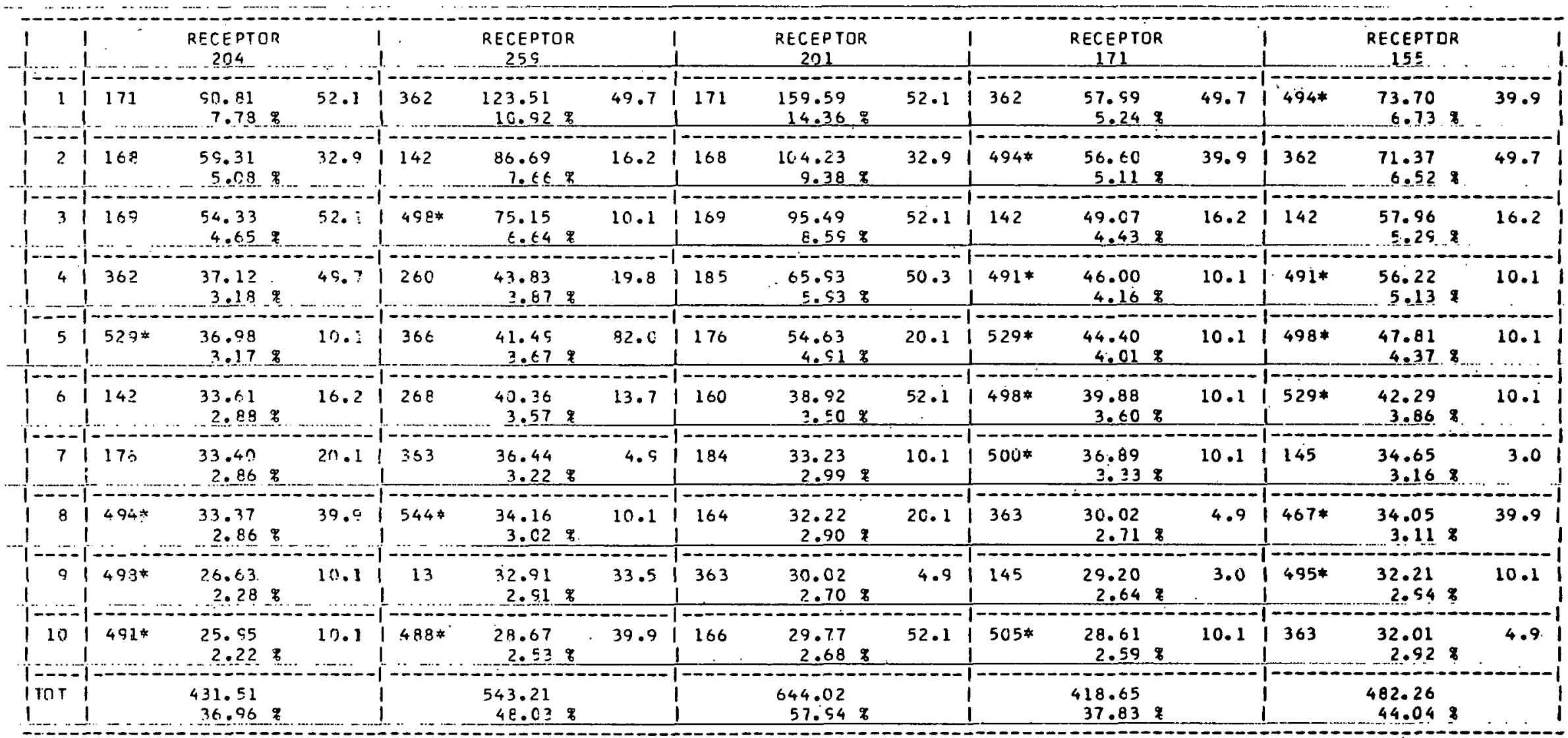

Fig. B-5 (Contd.) 


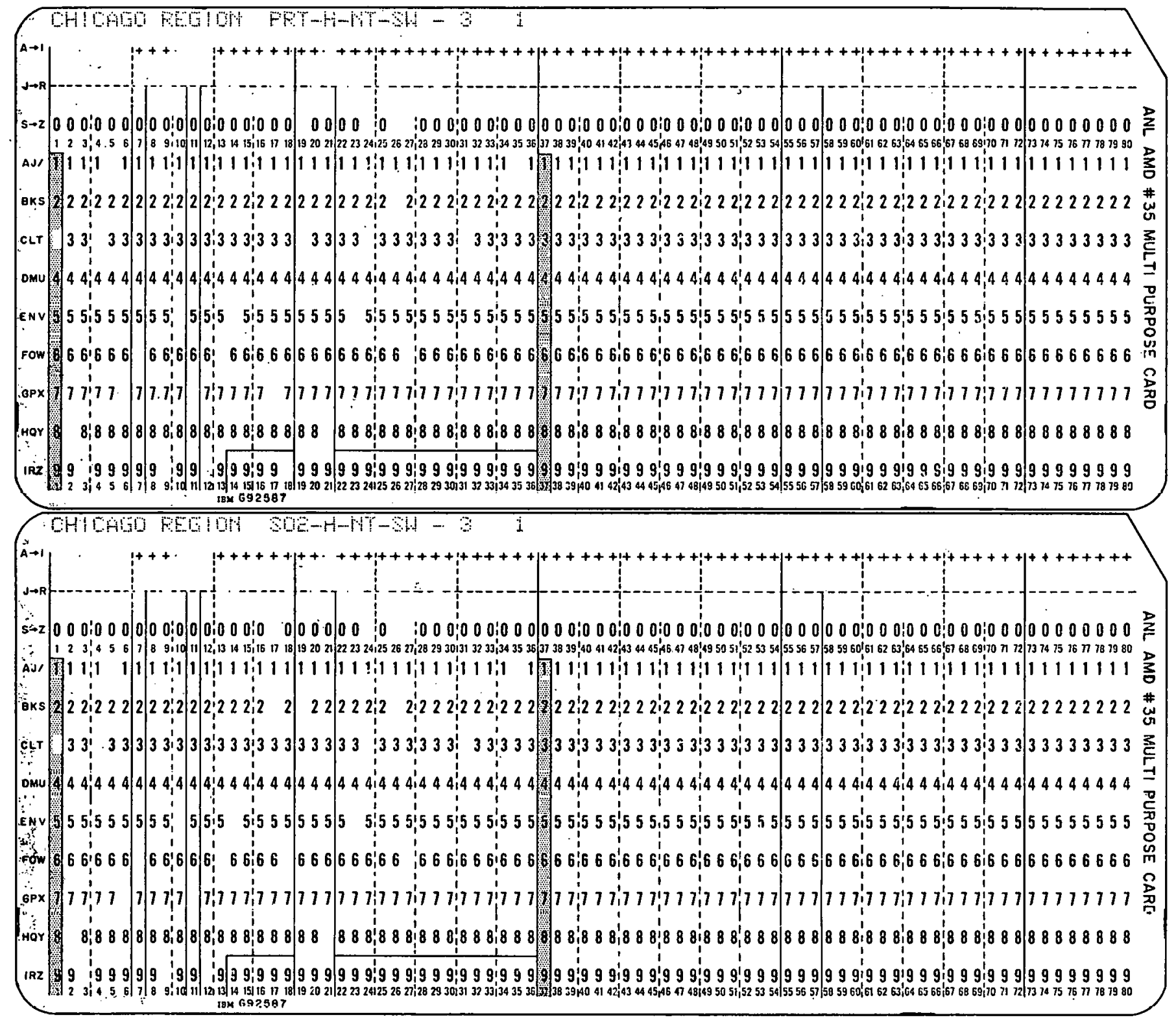

Fig. B-6. Punched-card Mutput from the Sample Problem 


\section{Sample Problem}

Included in this Appendix is a sample problem based upon data for the Chicago Metropolitan Air Quality Control Region. Since most of the components of the sample problem have been discussed in previous sections of this Appendix, the description contained here will be more in the way of a summary.

Figure B-4 contains the regular receptor grid used for the Chicago Region. The grid is of variable mesh in both directions and contains 256 points. There are an additional 12 non-grid receptors. Their X- and Ycoordinates (UTM System) are

$\begin{array}{ccc}1- & 444.40 & 4650.01 \\ 2- & 444.40 & 4645.02 \\ 3- & 447.61 & 4636.17 \\ 4- & 437.48 & 4634.96 \\ 5- & 432.73 & 4625.06 \\ 6- & 443.67 & 4625.62 \\ 7- & 450.51 & 4625.55 \\ 8- & 445.04 & 4607.21 \\ 9- & 454.05 & 4606.88 \\ 10- & 464.51 & 4609.62 \\ 11- & 402.56 & 4588.38 \\ 12- & 446.33 & 4615.73\end{array}$

The total receptor grid contains 268 points.

There are a total of eight meteorological cases to be considered. They include the winter and summer seasons. For each season, SW and NW winds with speeds of 0-3 knots and 4-6 knots are considered. For all these cases, the stability class is neutral, class 4 . Additionally, in the winter 
season, the emission rates of the following sources will be adjusted.

\begin{tabular}{cll} 
Source & \multicolumn{1}{c}{$\mathrm{SO}_{2}$ Rate } & Particulate Rate \\
\hline 69 & Reduced by $20 \%$ & Remains unchanged \\
107 & Reduced by $20 \%$ & Remains unchanged \\
171 & Remains unchanged & Reduced by $15 \%$ \\
178 & Remains unchanged & Reduced by $15 \%$ \\
362 & Reduced by $20 \%$ & Reduced by $15 \%$
\end{tabular}

The culpability list will assume the default format of the ten highest sources for each of the ten highest receptors.

A data file containing the receptor concentration dala for all eight cases will be output to logical unit 10. Additionally, aperture cards will be punched for $\mathrm{SO}_{2}$ and particulate isopleth plots.

Figure B-5 contains the printed output, receptor concentration data, and culpability lists for the first meteorological case, namely, winter season, neutral stability, and southwest wind of 0-3 knots. The isopleths for the $\mathrm{SO}_{2}$ concentrations are contained in Figures $\mathrm{C}-4$ and C-5 (in Appendix C) . 
APPENDIX C

$\frac{\text { Description and Use of ASSM Plotter Program }}{\text { (see Fig. C-1) }}$

1. Plotter Program Listing and Documentation

LIST OF SUBROUTINES

SUBROUTINE

DESCRIPTION

PAGE

AXES draws and labels coordinate axes on film

168

DECIDE internal subroutine to decide ambiguous cases

FLEXIN

inputs most of the data for producing film and printer displays; controls all routines for obtaining (2280) film output

GRAPH

produces isopleths $\left(\mathrm{SO}_{2}\right.$ or particulate) on film

IOCONV

converts machine representation to EBCDIC

OUTLIN

displays the geographical characteristics of a given region

SECDRV

internal routine for deciding ambiguous cases

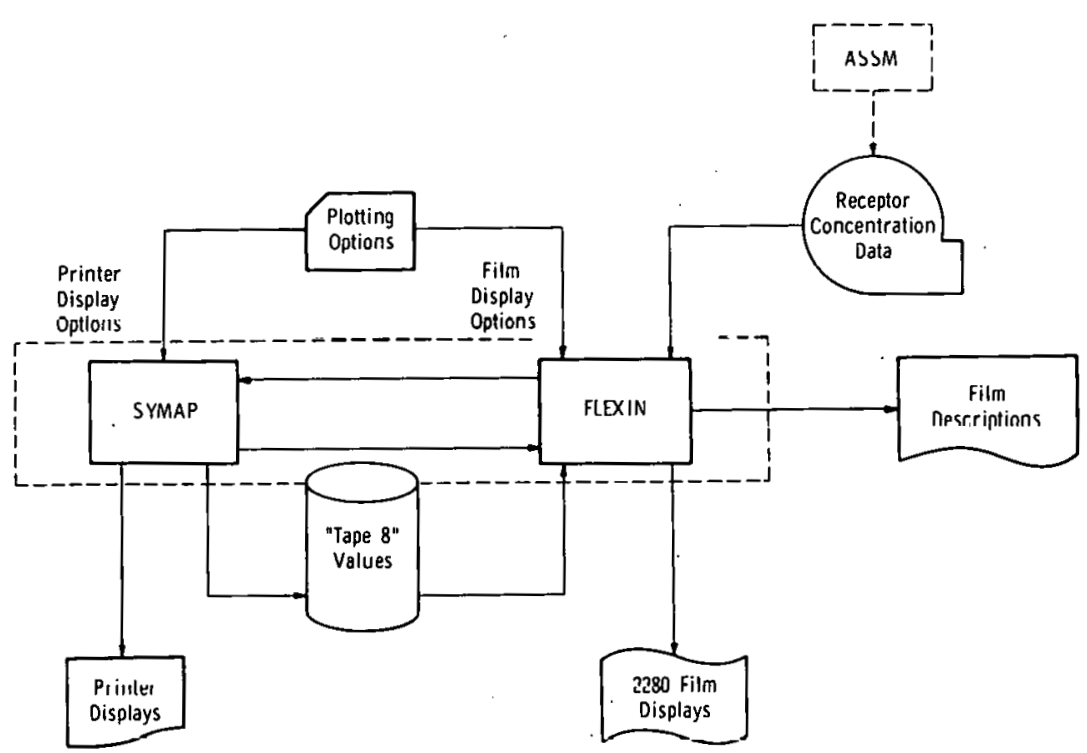

Fig. C.1. NSSM Plotting System 
a. Subroutine AXES

Description: This subroutine draws and labels the $\mathrm{X}$ (horizontal) and $\mathrm{Y}$ (vertical) axes on film. Tick marks appear at every 10-kilometer interval, and coordinate values appear at every 20-kilometer interval.

Parameters: SUBSQ logical variable whose value controls the gencration of the axes labels, .FALSE. for generating labels and .T̄RUE. for bypassing labè generation. Labels are generated each time a new grid system is inpui (B-DATA POINTS).

Output: $\quad$ Axes, together with labels, are drawn on film.

SUBROUTINE AXESTSSUBSQ)

C

C SUBROUTINE DRAWS AND LABELS THE X(HORIZONTAL) AND Y(VERTICAL) AXES. AXES

C AXES ARE LABELLED WITH TIC MARKS AT LACH 19 KILOMETER INTERVAL

C

$C$

C AND. WITH THE COORDINATE VALUE. AT EACH 20 KILOMETER INTERVAL. AXES

\section{LOEICAL SUBSQ}

COMMON/GRID/X1PLT, Y1PLT, X2PLT, YZPLT, CENTER, RU56

DIMENSION XLABEL.(2E). YLABEL.(2E)

If (5UBSU) \&U TU is

SUBSQ $=$.TRUE.

C FGENERATE THE "AXES" VALUES

$N N=$ MIN1 $((X 2 P L T-X 1 P L T-10.0) / 20.0+1.0 .20 .0)$

C GENERATE THE LABELS FOR THE HORIIZNTAL AXIS

INTX $=$ XIPLT $-1 B .8$

DO $5 I=1 . N N$

INTX $=$ INTX $+2 E$

CALL CONVO (' (IH)', XLABEL'(I);G.K. INTX)

5 CONTINUE

C GENERATE THE LABELS FOR THE VERTICAL AXIS

INTY $=$ YIPLT -10.0

DO $10 J=1$. NN

INTY $=$ INTY +20

CALL CONVO ' (I4)', YLABEL $(J), O, K$. INTY)

10 CONTINUE

C RUDD : DD RASTER UNITS IN 'USER' UNITS

RUE2 $=0.393 \approx$ RUS6

RUSE $=8.893 \neq$ RUSE
AXES

AXES 60

AXES 70

AXES 80

AXES 90

NXES 1ER

AXES 110

AXES 120

AXES 130

AXES 140

AXES 150

AXES 160

AXES 170

AXES 180

AXES 190

AXES 2EE

AXES 210

AXES 220

AXES 230

AXES . 240

AXES 250

AXES : 260

AXES 270

AXES. 280 


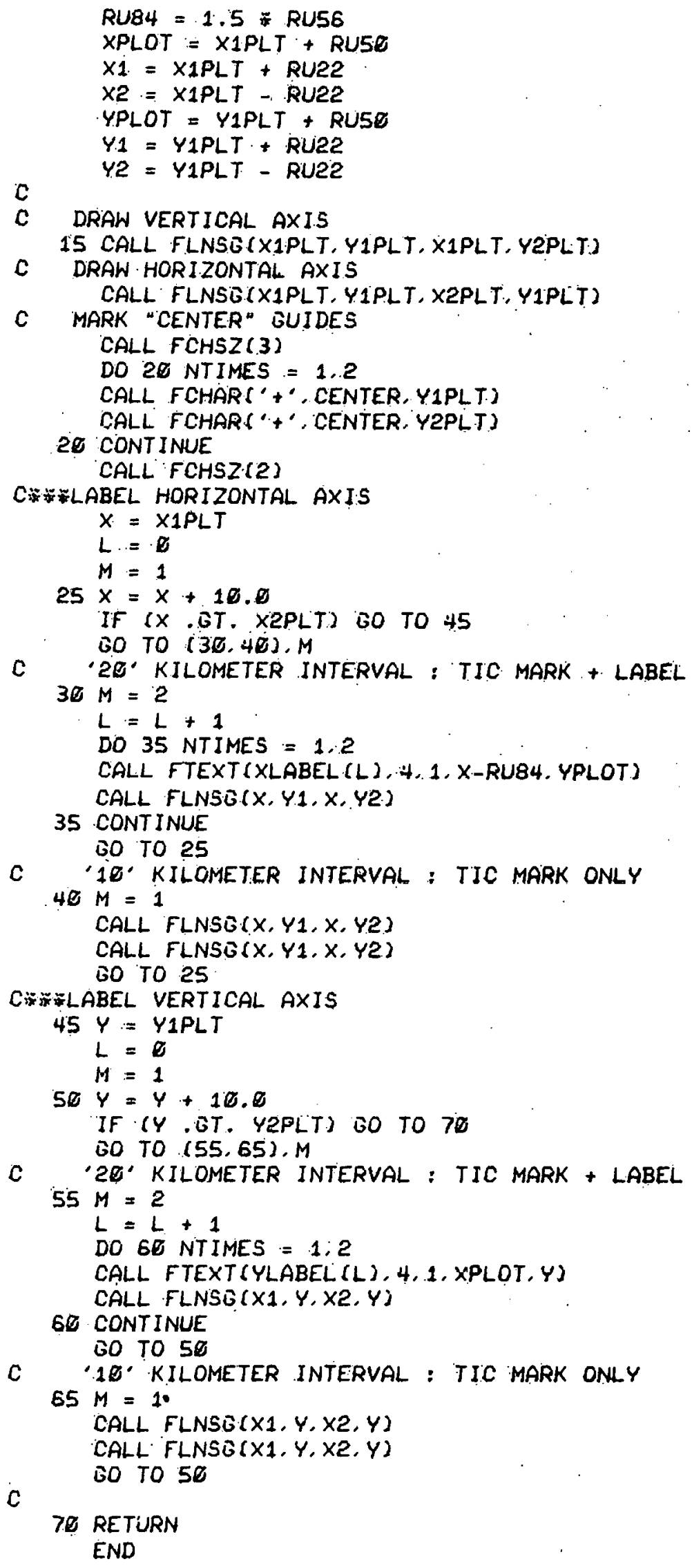

AXES 290

AXES 300

AXES 310

AXES $32 E$

AXES 330

AXES 340

AXES 350

AXES 360

AXES 370

AXES 380

AXES 390

AXES $4 E D$

AXES 4.10

AXES 420

AXES 430

AXES +40

AXES 450

AXES 460

AXES 470

AXES 480

AXES 496

AXES 500

AXES 510

AXES 520

AXES 530

AXES . 540

AXES 550

AXES 560

AXES 570

AXES 580

AXES 590

AXÉS 600

AXES 610

AXES 620

AXES 630

AXES 640

AXES 650

AXES 660

AXES 670

AXES 680

AXES 690

AXES $7 E D$

AXES 710

AXES 720

AXES 730

AXES 740

AXES 750

AXES 760

AXES 770

AXES 780

AXES 798

AXES 800

AXES 8.20

AXES 820

AXES 830

AXES 840

AXES 850

AXES 860

AXES 87\%

AXES 880

AXES 890

AXES 990 
b. Subroutine DECIDE

Description: This internal subroutine is accessed through GRAPH for the purpose of deciding the contour line to be drawn in certain ambiguous cases. A further description of the routine is available in Reference 13.

SUBROUTIINE DECIDE(M,N, X,Y,A, Y21,X32,Y34, X41, I.J.NT, L) DIMENSION $A(M, N), X(M), Y(N), D(2 ; 2,4), D T(4), V(2 ; 4), F(3,4,4)$ $N T=(I-1)(J-1)(I-M)=(J-N)(1-M-1)=(J-N-1)$ IF (NT) 19, 68, 10

$1 E$ IT (L)EQ. 4E, EE

$20 \quad L=0$

DO 30 KX K $=1.4$

DO $30 \quad K Y=1,4$

$F(1, K X, K Y)=X(I+K X-2)$

$F(2, K X, K Y)=Y(J+K Y-2)$

$30 F(3, K X, K Y)=A(I+K X-2, J+K Y-2)$

CALL SECDRV $F(1,2,2)$ F $(1,3$

$1 \quad D(1,1,1))$

DECI E

DECI 10

DFC.T $P G$

DECI 30

DECI 4Q

DECI 50

DECI $6 \mathbb{2}$

DECI 78

DECI 80

DECI 90

DECI 100

CALL SECDRV CF $(1,2,3), F(1,3,3), F(1,2,4), F(1,1,3), F(1,2,2), F(1,3,2), D E C I$ I $3 E$

$1 D(1,1,2))$

DECI 140

CALL SECDRV $(F(1,3,3), F(1,4,3), F(1,3,4), F(1,2,3) ; F(1,3,2), F(1,2,2), D E C I$ ISE

$1 \quad D(1,1,3))$

DECI 160

CALL SECDRV $(F(1,3,2), F(1,4,2), F(1,3,3), F(1,2,2), F(1,3,1), F(1,2,3), D E C I$ 1 170 $1 D(1,1,4))$

$40(1,1)=x(1)-X 41$

$V(2,1)=Y 21-Y(J)$

$V(1,2)=\dot{x} 32-x(I)$

$V(2,2)=Y(J+1)-Y 21$

$V(1,3)=x \cdot 32-x(1+1)$

$v(2,3)=Y(J+1)-Y 34$

$V(1,4)=x(1,1)-x+1$

DECI 180

DECI 190

DECI. 200

DECI 218

DECI 226

DECI 235

DECI 240

$V \cdot(2,4)=Y 34-Y(J)$

DO $5 E \cdot N C=1,4$

$D T E=E$.

DO $45 \quad K R O W=1.2$

DO 45 KOOL-1,2

$45 D T E=D T E+V(K R O W, N C)=D(K R O W, K C O L, N C)=V(K C O L, N C)$

5E $\operatorname{DT}(N C)=A B S(D T E) \div .5$

$N T=\operatorname{INT}(1.5+\operatorname{SIGN}(.126, \operatorname{DT}(1)-D T(2))+\operatorname{SIGN}(.126, \operatorname{DT}(1)-D T(4))$

$1+$ SIGNC.126. DT (3)-DT(2)) + SIGNC.126. DT (3)-DT(4).)

$N T=\emptyset$ FOR CASE 1 NT $=2$ FOR CASE 2 AND $N T=1$ IF UNDECIDABLE

DECI 250

DECI 260

DECI 270

DECI 280

DECI 298

DECI 300

DECI 310

DECI 320

DECI 330

DECI 348

DECI $35 E$

DECI 360

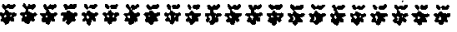

If" (NT . NL. 2.1 $3010 \quad 39$

MODIFICATION OF UNDECIDABLE CASE TO "CONTOUR" AROUND THE LARGEST

VALUES : APRIL 1971.

SUM1 $=0.5 \div(A(I, J)+A(I+1 . J+1))$

SUM2 $=0.5 *(A(I, J+1)+A(I+1, J))$

C SUM1 $>$ SUM2 CASE 1 NT $=-B$

$N T=\dot{\theta}$

DECI 370

DECI 380

DECI 390

DECI 4 EE.

DECI 418

$D E C I+20$.

DECI 430

DECI 448

DECI 450

SUM1 \& SUM2 CASE2 NT $=2$

IF (SUM1 , LT, SUM2) NT $=2$

C

C

$59 N T=(N T-1) *(3 \div N T-2)$

6I $N T=N T / 2+1$

RETURN

DECI 460

DECI 470

DECI 480

DECI 490

DECI 500

END 


\section{c. Subroutine FLEXIN}

Description:- This subroutine is an optional part of the "SYMAP program. It is used to input data under formats differing from standard SYMAP and to manipulate that data after it has been input and prior to its transmittal to SYMAP. A further description of this routine and the SYMAP program is contained in Reference 10. In the ASSM plotting system, this subroutine inputs the grid system and concentration data from ASSM and converts it to a form compatible with SYMAP. It also controls all film-plotting capabilities of the system.

Parameters: IFORM parameter selecting the "entry point" in FLEXIN corresponding to the appropriate SYMAP package. Its value and corresponding function are described in Section 2 of this appendix.

$\mathrm{T}$ used to transmit to SYMAP the $X$ and $Y$ coordinate values (B-DATA POINTS) and the corresponding function value (E-VALUES).

FIRST logical variable whose value is .TRUE. the first time FLEXIN is called for a given package. 
Output: The subroutine writes the identifying labels on film, and lists one page per display containing descriptive information for that display, including a table of the selected receptorș.

SUBROUTINE FLEXIN(IFORM.T.FIRST)

FLEX $\quad$ E

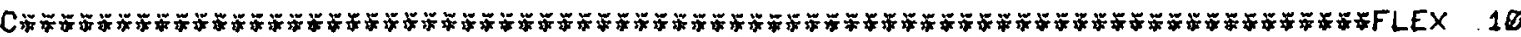
C SUBROUTINE DESIGNED TO ADD (2286) FILM PLOTTING CAPACITY TO SYMAPFLEX 20 C FOR ASSM DATA. OPTION 21 MUST BE USED TO CREATE "TAPE 8". FLEX 3G

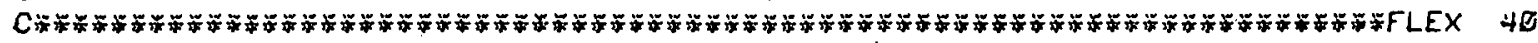
REAL 8 LABEL (2), LINE2 (2), SEASON(4), WINDSP(6) LOGICAL FIRST, NOREAD, SKPMSH, SUBSQ $\quad$ FLEX 60 COMMON/GRID/X1PLT, Y1PLT, X2PLT, Y2PLT, CENTER, RU56 FLEX 7E DIMENSION CZ(12), IRECEP(2,10), LINE1 (5), MARK(10), MPOLU(2), MSEA( 4$), F L E X$ BQ 1 MSTAB (5), MWDSP(6), RX (348), RY (340), S(130, 78), STABCL (15), T(2), FLEX 90 2 WINDR (16),X(130), Y(78),Z(12), ZPART (340), ZSO2(340) FLEX 18E EQUIVALENCE (LINE1(1), LABEL (1))

C

DATA LINE1/5\%4H

DATA MARK/1H1, 1H2, 1H3, 1H4, 1H5, 1H6, 1H7, 1H8, 1H9, $1 \mathrm{HE}$ DATA MFOLU/3HSO2. 3HPRT/

DATA MBEA'1HH, 1H3. 1HN, 1HF;

DATA MSTAB/2HVU, 2HMU, 2HSU, 2HNT, 2HST/

DATA MWDSP/2H 3.2H 6, 2H16.2H16, 2H21, 2H25/

DATA SEASON/BHWINTER, 8HSPRING, 8HSUMMER, 8HFALL

DATA STABCL/4HV-UN, 4HSTAB, 4HLE , 4HM-UN, 4HSTAB, 4HLE , 4HS-UN,

4HSTAB, 4HLE . 4HNEUT, 4HRAL , 4H . 4HSTAB, 4HLE, $4 \mathrm{H}$

DATA WINDR/ $4 \mathrm{HN}, 4 \mathrm{HNNE}, 4 \mathrm{HNE}, 4 \mathrm{HENE}, 4 \mathrm{HE}, 4 \mathrm{HESE}, 4 \mathrm{HSE}$,

1 4HSSE, $4 \mathrm{HS}, 4 \mathrm{HSSW}, 4 \mathrm{HSW}, 4 \mathrm{HWSW}, 4 \mathrm{HW}, 4 \mathrm{HWNW}, 4 \mathrm{HNW}$,

2 4HNNW

DATA WINDSP/8H $0-3, .8 H+6,8 H 7 \cdot-10.8 H 11-16$,

* $8 \mathrm{H} 17$ - 21 . BHOVER 21

DATA IMAX. JMAX, SUBSQ/130, 78, .FALSE./

$c$

60 TO (1E, 20, 30, 35, 40, 45), IFORM

$C$ Cats

FLEX 180
FLEX 110

FLEX 120

FLEX 136

FLEX $1+0$

FLEX 150

FLEX 160

FLEX 170

FLEX 180

FLEX 190

FLEX 2GE

FLEX 210

FLEX 220

FLEX 230

FLEX 240

FLEX 250

FLEX 260

FLEX 270

FLEX 280

F"LEX 290

FLEX 300

FLEX 310

FLEX 320

FLEX 330

FLEX 340

FLEX 350

FLEX 36E

FLEX 370

FLEX 380

FLEX 390

FLEX 4 EE

DO $5 I=1 . \mathrm{NZ}$

$I Z=Z(1)$

CALL CONVO' ' $(14) \cdot . \mathrm{CZ}(1), 0, K, 1 Z)$

5 CONTINUE

$Z N Z=Z(N Z)$

$c$

NSKIP = NCASE - ICASE

IF (NSKIP) $16,4,1$

C SKIP THE FIRST 'NSKIP' CASE(S) ON UNIT 'INPUT'

1 DO $3 \mathrm{NN}=1$. NSKIP

2 READ (INPUT, 1E5) IDENT

IF (IDENT.GE. E) 60 TO 2

C NEXT TWO RECORDS CONTAIN THE SELECTED RECEPTORS

READ (INPUT, 185) IDENT

READ (INPUT, 1E5) IDENT

3 CONTINUE

c

'LAST' IS THE NUMBER OF LAST CASE INPUT

4 LAST = NCASE - 1

IF (NSELC .LE, E) NCASE = LAST

IF (SIZE . GT, 1.15 ) SIZE $=1.15$

FLEX 410

FLEX 420

FLEX +30

FLEX 440

FLEX 450

FLEX $46 E$

FLEX 470

FLEX $48 E$

FLEX 490

FLEX 580

FLEX 510

FLEX 520

FLEX 530

FLEX 540

FLEX .55\%

FLEX 56E

FLEX 570

FLEX .580

FLEX 590 
$N=0$

$12 N=N+1$

READ (INPUT, 11E) RX(N), RY(N), ZSO2(N), ZPART(N)

IF (RX(N) . GE. D.E) GO TO 12

READ (INPUT, 140) (IRECEP (1,L), $L=1,10$ )

c

READ (INPUT, 140) (IRECEP (2,L), $L=1,10$ )

NRECS $=N+2$

NPTS $=N-1$

NOREAD $=$. TRUE.

C DECODE RX(N)

SKPMSH $=$ FALSE

$I D E N T=100.0 \div(A B S(R \times(N))+8.005)$

ISEA = IDENT/10EEO

IDENT = IDENT - 1QEEE ISEA

$I S T A B=I D E N T / 10 Q 0$

$I D E N T=I D E N T-1 E G E I S T A B$

$I W D=I D E N T / 1 Q$

IWS = IDENT - 10 IWD

C * OET UP PLOTTING LIMITS AND POSITIONS FOR IDENTIFYING LABELS :

$C$ ASSUME LENGTH OF $X$ AND $Y$ AXES ARE IDENTICAL

WIDTH $=$ X2PLT - X1PLT

CENTER $=\times 1 P L T+E .5 \% W I D T H$

$X L=W I D T H \div 1.17 / S I Z E$

C RU56:56 RASTER UNITS IN USER' UNITS

RU56 $=0.013672 \div \times L$

$D L=0.5 \div(X L-$ WIDTH $)$

C LIMITS OF ACTUAL FILM PLOTTING AREA

$X 1=X 1 P L T-D L$

$Y 1=Y 1 P L T-D L$

$X 2=X 2 P L T+D L$

C HORIZONTAL POSITIONS FOR LABELS

AXPOS $=$ X2PLT - O.34 3 WIDTH

BXPOS $=$ X2PLT -0.215 WIDTH

CXPOS $=\times 2 P L T-0.19 \times W I D T H$

$\mathrm{C}$
$\mathrm{C}$
$\mathrm{C}$

YPOS1 $=$ YZPLT -0.075 WIDTH

C VERTICAL SPACING FOR LABELS: 33 LINES FOR LARGE-SIZE CHARACTERS: 48 LINES FOR BASIC-SIZE CHARACTERS $51=$ WIDTH $/ 33$

YPOSE = YPOS1 - S1

YPOS3 = YPOSE - S1

$c$

$S 2=$ WIDTH $/ 48$

$\mathbf{C}$

$$
N=\boldsymbol{B}
$$

$14 N=N+1$

If ( $N$. BT. NPTS) GO TO 98

$T(1)=-R Y(N)$

$T(2)=R \times(N)$

GO TO 99

C FERROR EXIT FOR CASE SELECTED

16 WRITE (6. 290) ICASE, NCASE. INPUT STOP. 99

$C=$

C E-VALUES (SO2): IFORM $=2$

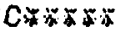

20 IF (.NOT. FIRST) GO TO 26

NCASE $=$ NCASE +1

FLEX 6EO

FLEX 610

FLEX 620

FLEX .630

FLEX 640

FLEX 650

FLEX 668

FLEX 670

FLEX 680

FLEX 690

FLEX. 7EE

FLEX 710

FLEX 720

FLEX 730

FLEX 740

FLEX 750

FLEX 760

FLEX 770

FLEX 780

FLEX 79E

FLEX 809

FLEX 810

FLEX 820

FLEX 830

FLEX 840

FLEX 850

FLEX 860

FLEX 870

FLEX 880

FLEX 898

FLEX 90E

FLEX 910

FLEX 920

FLEX 9:30

FLEX 940

FLEX 950

FLEX 968

FLEX 970

FLEX 98E

FLEX 998

FLEX1EGE

FLEX1010

FLEX1E20

FLEX1030

FLEX1048

FLEX1050

FLEX1E60

FLEX1Q70

FLEX1E8E

FLEX1098

FLEX1100

FLEX1110

FLEX1120

FLEX1130

FLEX114E

FLEX1150

FLEX1160

FLEX1170

FLEX118D

FLEX1190 


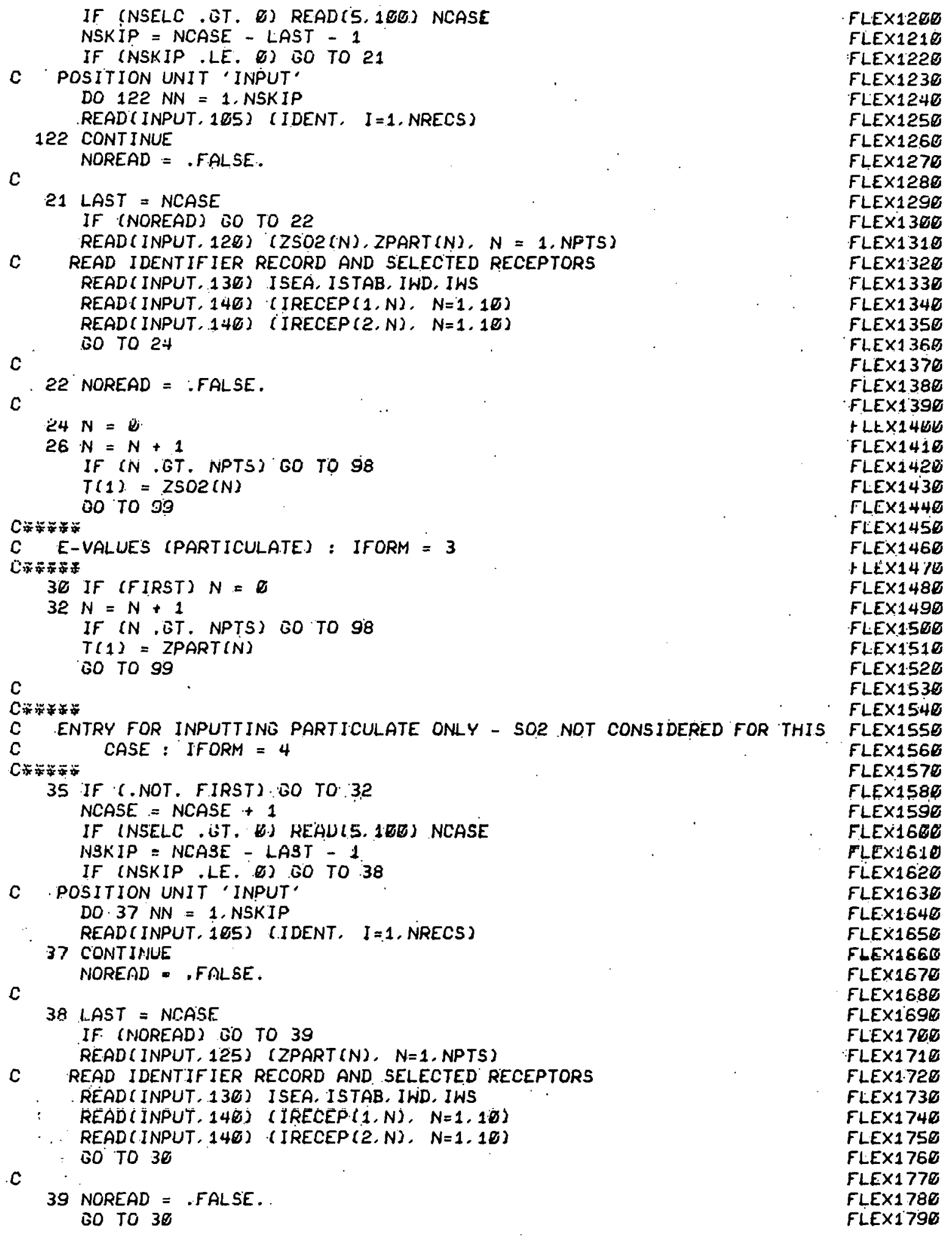


C

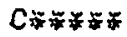

C ENTRY FOR PLOTTING SOR : IFORM $=5$

FLEX18EO

$C$ C

c

4E IPOLUT $=1$

FLEX1820

C.F IND MAXIMUM CONTOUR VALUE

NCNTR $=N Z$

$Z M A X=0 . E$

DO $41 \mathrm{~N}=1$, NPTS

$I=N P T S-N+1$

IF. (ZSO2(I) . ET. ZNZ) GO TO 50

IF (ZSO2(I.) . GT. ZMAX) ZMAX = ZSO2(I)

C

41 CONTINUE

IF (ZMAX.GE.Z(1)) GO TO 141

$N C N T R=Q$

BO TO 50

241 CONTINUE

DO $+2 N=1, N Z$

$K=N Z-N+1$

If (ZMAX . GE. Z(K)) GO TO 43

42 CONTINUE

GO TO 58

43 NCNTR $=\cdot K$

C的和的

GO TO $5 E$

C ENTRY FOR PLOTTING PARTICLLATE : IFORM =6

C)

C

45 IPOLUT $=2$

CWFIND MAXIMUM CONTOUR VALUE

NCNTR $=N Z$

$Z M A X=D .0$

DO $46 \mathrm{~N}=1$. NPTS

$I=N P T S-N+1$

IF (ZPART (I) . . GT., ZNZ) GO TO .5E

IF (ZPART(I) . GT. ZMAX) ZMAX = ZPART(I)

46 CONTINUE

IF (ZMAX.GE.Z(1).) GO TO 147

NCNTR $=E$

SO TO 50

147 CONTINUE

$$
\text { ; }
$$

DO $47 N=1 . N Z$

$K=N Z-N+1$

IF (ZMAX .GE. Z(K)) GO TO 48

4? CONTINUE:

GO TO SE

c

48 NCNTR $=K$

$C \div$

C PRODUCE (2R8E) GRAPHICAL DISPLAYS : INPUT VALUES ON "TAPE 8 "

FLEX1830

FLEX1840

FLEX1850

FLEX1860

FLEX1870

FLEX1880

FLEX1890

FLEX1900

FLEX1910

FLEX1920

FLEX1930

FLEX1940

FLEX1958

FLEX1960

FLEX1970

FLEX1980

FLEX1990

FLEX2BEE

FLEX2010

FLEX2020

FLEX2030

FLEX2E48

FLEX2050

FLEX2E60

FLEX2E7E

FLEX2E80

FLEX2B90

FLEX210E

FLEX2110

FLEX2128

FLEX2130

FLEX2140

FLEX2150

FLEX2160

FLEX2170

FLEX2180

FLEX2198

FLEX2200

FLEX2210

FLEX2220

FLEX2230

FLEX2240

FLEX2250

FLEX2260

FLEX2270

FLEX2280

FLEX2290

FLEX2308

FLEX2310

FLEX2320

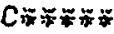

5E. REWIND 8

READ ( 8 ) NY, NX,DY, DX

IF (SKPMSH) 60 TO 56

FLEX2330

FLEX23:H

FLEX2350

FLEX2360

SKPMSH $=$. TRUE.

DO $52 \mathrm{~J}=1$. NY

FLEX2370

FLEX2380

$\because J=N Y-J J+1$

FLEX2390 
$Y(J)=Y M A X-J J / D Y$

FLEX2்4GO

C

52 CONTINUE

FLEX2+10

DO $54 I=1 . N X$

$X(I)=X M I N+I / D X$

FLEX2+20

FLEX2430

FLEX2440

C

54 CONTINUE

C DETERMINE CORNERS OF EXCLUSION AREA

FLEX2450

FLEX2+60

FLEX2470

DO $53 J=1$. NY

If $(Y(J)$. GE, YPOS3) BO TO 153

53 CONTINUE

$J=N Y$

C

$153 L Y_{1}=J-2$

DO $57 I=1, N X$

IF $(X(I)$. GE. AXPOS) BO TO 157

57 CONT INUE

$I=N X$

c

$157 L X 1=I-1$

56 D० :58 J J $=1, N Y$

$J=N Y-J J+1$

$\operatorname{READ}(8)(S(I, J), I=1, N X)$

58 CONTINUE

REWIND 8

$c$

IF (SUBSQ) TO TO 60

C INITIALIZE F.SP

CALL FINIT $(1,2)$

CALL FLIND(1)

CALL FLINW(1)

CALL FDATM(2)

SUBSQ = . TRUE.

c

C) FLOT ISOPLETHS

BD DO 50 LOOP = 1. NCOPYS

CALL FXYLIM(X1, Y1, X2, Y2)

C

CALL AXES (XYDATA)

CALL FERROR (KERR)

C

IF (KERR. NE. O) WRITE (6, 255) KERR

FLEX2480

FLEX2490

FLEX2580

FLEXX2510

FLEX2520

FLEX2530

FLEX2548

FLEX2550

FLEX2560

FLEX2570

FLEX2589

FLEX2590

FLEX2600

FLEX2610

FLEX2620

FLEX2638

FLEX2640

FLEX2650

FLEXE660

FLEX2670

FLEX2680

FLEX2698

FLEX2700

FLEX2710

FLEX2720

FLEX2730

FLEX2740

FLEXR750

FLEX2760

FLEX2770

FLEY278R

FLEX2790

FLEX2800

FLEX2810

FLEX2820

CALL OUTLIN

CALL FERROR (KERR)

C

IF (KERR .NE. E) WRITE (6, 26E) KERR

FLEX2830

FLEX2840

FLEX2858

FLEX2860

IF (NCNTR.EQ.E) GO TO 163

DO 62 NTIMES $=1.2$

CALL GRAPH(NCNTR, Z, X, Y, S, IMAX, JMAX, 1, 1, LX1, NY)

CALL GRAPH (NCNTR, Z, X, Y. S. IMAX. JMAX, LX1, 1. NX, LY1)

FLEX2870

F.LEX2880

FLEX2890

FLEX2900

FLEX2910

CALL FERROR.(KERR)

IF (KERR . NE. E) WRITE (6. 27E) KERR

16.3. CONT INUE

IF (LDOP . BT. 1) BO TO 63

FLEEX2920

FLEX2930

FLEX2940

FLEX2950

$C$

Cir

CALL CONVO ' (I3)', LINE1, 16, K. NCASE)

CALL CONVO ' (A.3)', LINE2, $0, K, M P O L U$ (IPOLUT) )

FLEX2960

FLEX2970

FLEX2980

CALL CONVO ('(A1)'. LINE2. 4. K. MSEAI ISEA))

FLEX2998 
$c$

63 CALL FCHSZ(3)

DO 64 NTIMES $=1,3$

LALL FTEXTCLINE1 (5), 3, 1, BXPOS, YPOS1)

CALL FTEXT(LINE1, 16, 1, AXPOS, YPOS2)

CALL FTEXT(LINE2, 15, 1, AXPOS, YPOS3)

64 CONTINUE

CALL FCHSZ(2)

IF (NCNTR.EQ.E) GO TO 166

$Y Y=Y P O S 3$

DO $65.5 I=1$. NCNTR

$N=$ NCNTR $-I+1$

$Y Y=Y Y-S 2$

DO 165 NTIMES $=1.2$

IF (I .EQ. 1) CALL FTEXT' 'CONTOURS', 8.1. AXPOS, YPOS3-52)

CALL FTEXT $(C Z(N), \therefore, 1$, CXPOS, YY)

c

c

65 CONTINUE

166 CONTINUE

$c$

IF (LOOF . BT. 1) GO TO 71

C

WRITE (6, 258) LINE1, LINE2

GO TO $(66,68)$, IPOLUT

66 WRITE $(6,150)$

$60 \div 078$

c

68 WRITE $(6,160)$

70 WRITE $(6,170)$ SEASON (ISEA)

$I 1=(I S T A B-1) 3+1$

$12=11+2$

WRITE $(6,188) \cdot(S T A B C L(I), I=I 1, I 2)$

WRITE (6, 198). WINDR (IWD)

WRITE $(6,200)$ WINDSP (IWS)

C) MARK RECEPTOR LOCATIONS

71 If (NRECEP .EQ. E) GO TO 80

IF (LOOP . GT. 1) 60 TO 73

C

c

WRITE (6, 22E)

73 DO $78 \mathrm{~N}=1$. NRECEP.

$I=I R E R F P(I P O \mid U I T \cdot N)$

$R \times I=R \times(I)$

RYI = RY (I)

DO 72 NTIMES $=1,2$

CALL FCHAR (MARK (N), RXI, RYI)

72 CONTINUE

IF (LOOP .GT. 1) 60 TO 78

$c$
$c$

LIST THE SELECTED RECEPTORS

HRITL $(G, \varepsilon 3 E)$ N. I, RXI. RYI

60 TO $(74,76)$. IPOLUT

74 WRITE (6, 24E) ZSO2(I)

BO TO 78

76 WRITE (6, 246) ZPART (I)
FLEX $30 E 0$

FLEX 3018

FLEX3020

FLE $\times 3030$

FLEX3E48

FI F $\times 3.5 .59$

FLEX3E60

FLE $\times 3070$

FLEX3E80

FLE $\times 3890$

FLEX31RE

FLEX3110

FLEX3128

FLEX3130

FLEX314E

FLEX315E

FLEX3168

FLEX3170

FLEX3180

FLE $\times 3190$

FLEX3200

FLEX3210

FLEX 3220

FLEX3230

FLEX3240

FLEX 3250

FLEX3260

FLEX3270

FLEX 3280

FLEX3290

FLEX3360

FLEX3310

FLE $\times 3320$

FLEX3338

FLEX3340

FLEX 3358

FLEX3360

FLE $\times 3370$

FLEX 3380

FLE $\times 3390$

FLEX 34 EE

FLEX 3410

FLEX 3428

FLEX 3430

FLEX 3448

FLE $\times 3450$

FLE $\times 3460$

FLEX3478

FLEX 3480

FLE $\times 3490$

FLEX3500

FLE $\times 3510$

FLE $\times 3520$

FLE $\times 3530$

FLEX3540

FLEX $35 \overline{5}$

FLEX3560

FLEX 3570

FLEX3580

FLEX3598 
78 CONTINUE CALL FERROR (KERR)

c IF (KERR :NE. E) WRITE (6, 288) KERR

FLEX3600

80 CALL FADV (4)

c

9g CONTINUE

98 IFORM $=99999^{\circ}$

C

99 RETURN

160 FORMAT.(7I6.8X, 2A8/7F8.8/12F6.8)

185 FORMAT (I7)

110 FORMAT $(2(F), 2,1 \times), 1 \times, 2(F 8,2,1 \times))$

120 FORMAT (17X,F8,2,1X,F8,2)

125. FORMAT (26x. F.8.2)

130 FORMAT (2X,.2I1, I. I, I1)

140 FORMAT (10I6.)

150 FORMAT (1HE. 1EX, 'POLUTANT', 9X, 'SO2')

160 FORMAT (1HE. 1EX. 'POLUTANT', 9x, 'PARTICULATE')

170 FORMAT (1HE, 1EX, 'SEASON', $11 X: A 8)$

180 FORMAT (1HO. 1EX, 'STABILITY', 8X, 3A4)

190 FORMAT!1HE. 16X. 'WIND DIRECTION', $3 X, A 4)$

200 FORMAT I 1HB, 18X, 'WIND SPEED',7X, A8.' KNUTS'?

220 FORMAT $/ / / 1 H \theta, 17 X$. 'RECEPTOR CONCENTRATION DATA'/1H . 1EX.

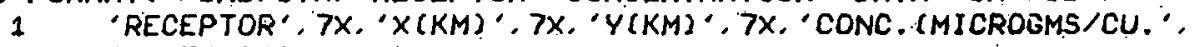
2 'METERI')

23E FORMAT (1HE, I6, 5X, I5, 2X, 2F 12,2$)$

240 FORMAT (1H+, 42X. F14.2)

250 FORMAT(1H1,1EX. 'MAP SUMMARY INFORMATION'/1HE, 10X, 5A4/ * $1 H, 18 \times, 2 A 8 / 3$

255. FORMAT(1HE, 1EX. 'ERROR CODE'. I4;' FROM GRIDS'/)

26E FORMAT(1HE, 1EX. 'ERROR CODE',I4,' FROM OUTLIN'/)

27. FORMAT(1HE, 16X. 'ERROR CODE'. I4,' FROM GRRPH'/)

280 FORMAT(1HE. 1EX. 'ERROR CODE'. I4.' FOR RECEPTORS'/)

290 FORMAT (1HO, 10X. 'INITIAL CASE $('$ 'I4.' ') ON UNIT'. I4,

c

- LARGER THAN DESIRED CASE (". I4.') -- TERMINATE'/)

END

FLE $\times 3630$

FLEX3640

FLEX 3650

FLEX366日

FLEX3670

FLEX3680

FLEX 3690

FLEX3700

FLEX3710

FLEX3720

FLEX 3730

FLEX3740

FLEX3750

FLEX3760

FLEX3770

FLEX3780

FLEX3790

FLEX 3800

FLEX381E

FLEX 3829

FLEX3830

FLEX3840

FLEX3850

FLEX 3860

FLEX3870

F.LEX3880

FLEX3898

FLEX 3900

FLEX391E

FLEX3920

FLEX 3930

FLE $\times 3948$

FLEX3950

FLEX3960

FLEX3970

FLEX 3980 
d. Subroutine GRAPH

Description: This subroutine produces isopleths of the function $\Phi(X, Y)$ on film. A more detailed description is contained in Reference 13.

Parameters: IZ number of contour values to be plotted

$Z$ array containing the IZ contour values

$\mathrm{X}$ array containing the horizontal coordinate values of the grid

Y array containing the vertical coordinate values of the grid

A array containing the function-values

$\Phi(X, Y)$, i.e,,$A_{i j}=\Phi\left(X_{i}, Y_{j}\right)$

IMAX row dimension of $\mathrm{A}$

JMAX column dimension of A

$\mathrm{I} 1, \mathrm{~J} 1, \mathrm{I} 2, \mathrm{~J} 2$ indices that delineate that portion of the grid

to be used in plotting. That is, only the

function values $A(I, J)$, where $I 1 \leq I \leq I 2$ and

$\mathrm{J} 1 \leq \mathrm{J} \leq \mathrm{J} 2$, are considered.

Isopleths $\left(\mathrm{SO}_{2}\right.$ or particulate $)$ are drawn on film.

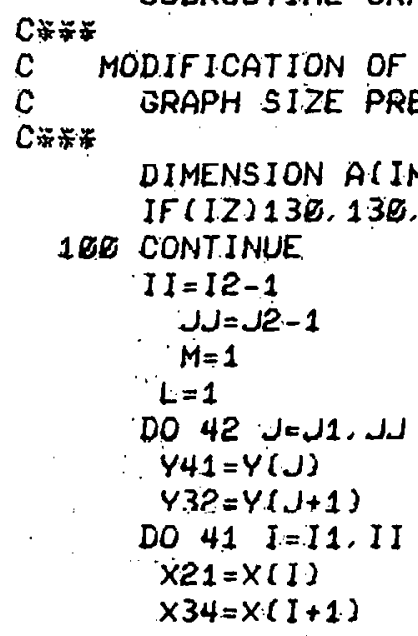




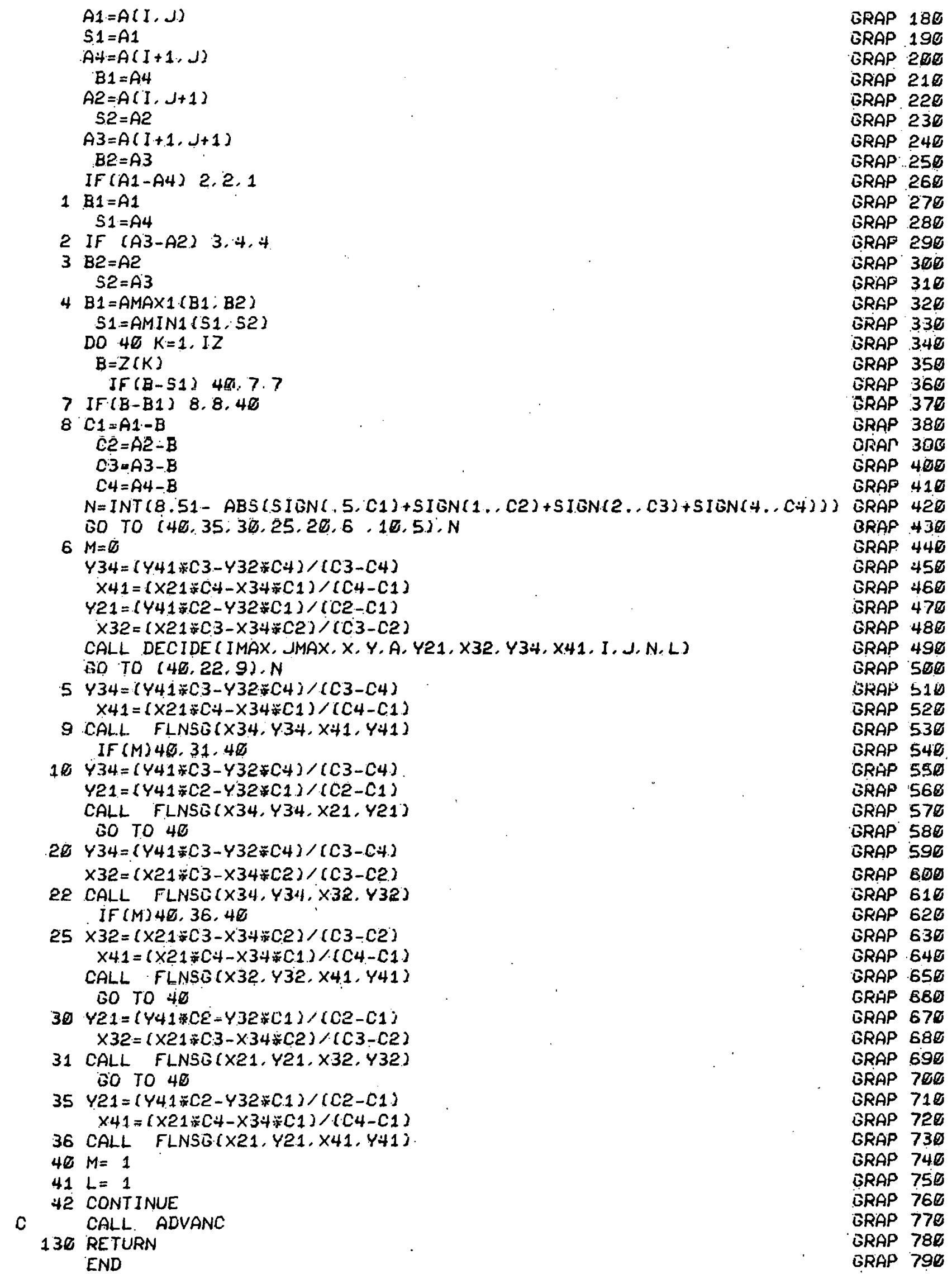


e. Subroutine OUTLIN

Description: This subroutine displays the geographical characteris-

Lics (boundaries, rivers, ...) of the region. Coordinates

are in the UTM system.

Since the subroutine describes a particular region, a

different routine is required (user-supplied) for every

region. The routine listed here is for the Chicago

region.

Output: The geographical characteristics of the particular

study region are drawn on film.

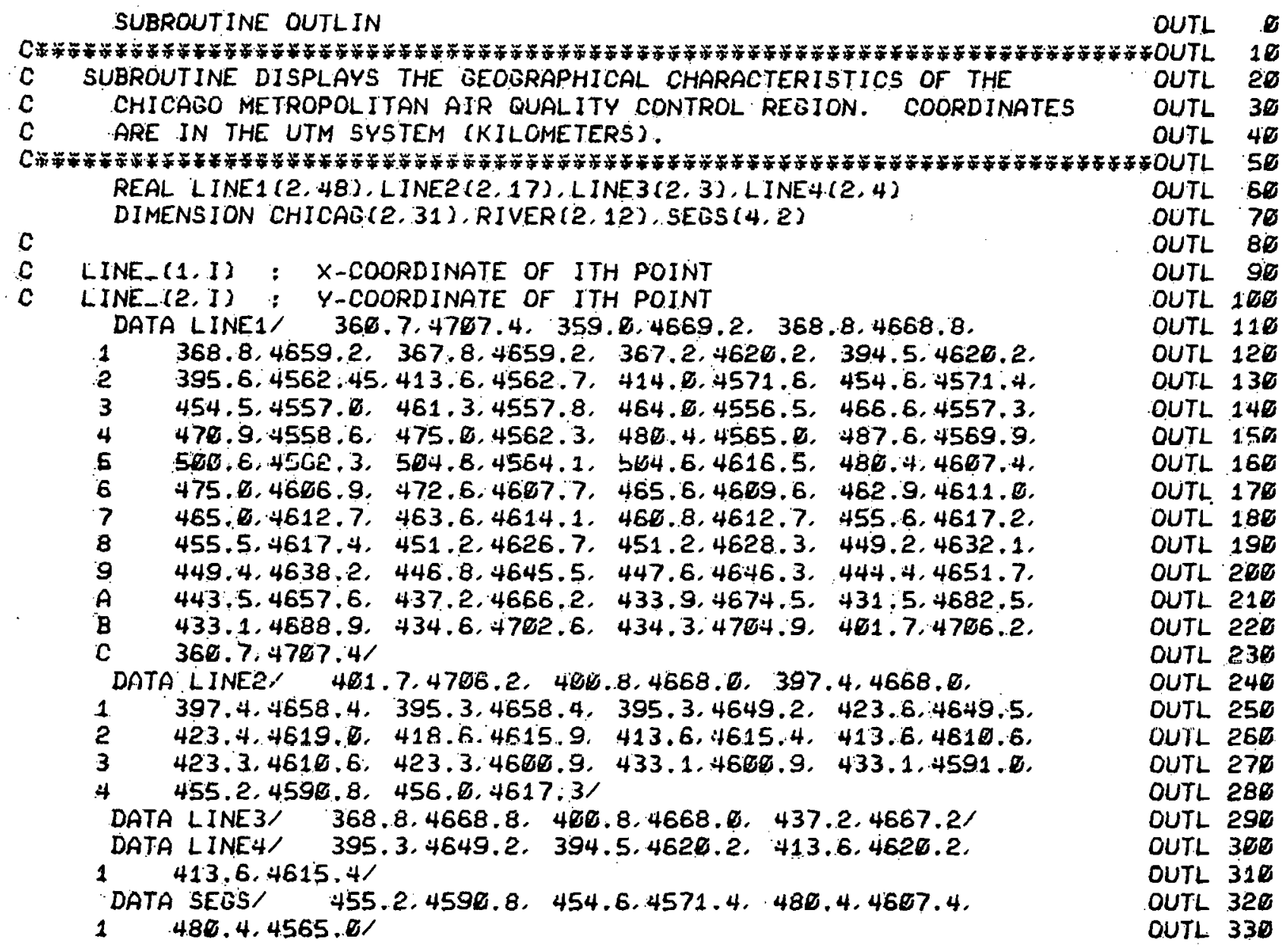


CW

DATA CHICAG/ $444.4,4652.7,441.2,4652.7,441.2,4650.3$.

$1438.0 .4650 .3,436.4,4649.5,434.6,4649.5,435.5,4648.7$.

$2 \quad 433.1 .4648 .7,433.1 .4651 .1,431.8 .4651 .1,431.5,4648.4$.

$3 \quad 429.1 .4648 .4,429.1 .4643 .1,433.1 .4642 .3,433.1 .4639 .5$.

$4 \quad 434.7 .4639 .5,434.7 .4635 .0,438.0 .4635 .0,438.0 .4630 .2$,

$5 \quad 436.4 .4628 .6,433.1 .4628 .6,433.1,4625.4,438.0 .4625 .4$.

$6 \quad 438.0 .4620 .6,442.8,4620.6,442.8,4617.3,439.5,4617.3$.

$7 \quad 439.5,4614.1,443.6,4613.5,448.4,4610.9,455.6,4610.9 /$

C

DATA RIVER/ $396.1,4583.5,460.9 .4588 .4,461.8,4591.6$.

$1467.4,4596.4,489.8,4683.8,412.2,4613.3,423.4,4624.6$,

$2428.6,4623.8,433.1,4627.8,446.8,4633.9,446.8,4637.1$.

$3 \quad 449.2,4637.5 /$

DATA NPTS1, NPTS2, NPTS3, NPTS4, NSEGS, NCHIC, NRIVER/ 48, 17, 3, 4.

$c$ F 2. $31: 12$,

$$
\text { DO } 10 \text { LOOP }=1.2
$$

$c$

DRAW LINE-1

DO. 1 I $=\varepsilon$. NPTS1

CALL FLNSECLINE1 (1, 1-1), LINEA I (2; I-1), LINE 1 (1, I), LINE 1 (E, I ).)

1 CONTINUE

C DRAW LINE_-2

DO $2 I=2$. NPTS2

CALL FLNSE(LINE2 (1, I-1), LINE2 (2, I-1), LINE2 (1, II, LINE2 (2, I )

2. CONTINUE

C DRAW LINE-3

DO $3 I=2$, NPTS3

CALL FLNSG(LINE3(1, I-1), LINE3 (2, I-1), LINE3 (1, I), LINE3 (2, I )

3 CONTINUE

C DRAW LINE_4

DO $4 I=2$, NPT.54

CALL FLNSG.(LINE4 (1, I-1), LINE4 (2, I-1), LINE4(1, I), LINE4(2, I)

4 CONTINUE

C DRAW LIAL SECMENTS

DO 5 I - 1. NSEBS

CALL FLNST $(S E G S(1,1), \operatorname{SEGS}(2,1), \operatorname{SEGS}(3,1), \operatorname{SEGS}(4,1)$.

5 CONTINUE

C DRAW CHICAGO

DO $6 I=2$. NCHIC

CALL FLNSG (CHICAG (1, I-1), CHICAG(2, I-1), CHICAG (1, I), CHICAG (2, I))

E CONTINIUE

C DRAW "RIVER"

DO $7 I=2$. NRIVER

CALL FLNSG(RIVER (1,I-1), RIVER (2, I-1), RIVER(1, I), RIVER(2, I )

c.

7 CONTINUE

16 CONTINUE

RETURN

END

OUTL 340

OUTL 350

OUTL 360

OUTL 370

OUTL 380

OUTL 390

OUTL 4EO

OUTL +10

OUTL 420

OUTL 430

OUTL 440

OUTL 450

OUTL 460

OUTL 470

OUTL 480

OUTL 498

OUTL 5EE

OUTL 510

OUTL 528

OUTL 530

OUTL 54E

OUTL S5D

OUTL 560

OUTL 579

OUTL $58 \dot{0}$

OUTL 590

OUTL 6EQ

OUTL 610

OUTL 620

OUTL 630

OUTL 648

OUTL 650

OUTL 660

OUTL 670

OUTL 6BE

OUTL 698

OUTL 7EE

OUTL 710

OUIL T2E

OUTL 738

OUTL 748

OUTL 750

OUTL 760

OUTL 778

OUTL 780

OUTL 790

OUTL BEO

OUTL 810

OUTL 820

OUTL .83G

OUTL 840 
f. Subroutine SECDRV

Description: This internal subroutine is used for deciding which contour line should be drawn in certain ambiguous cases. A further description of the routine is contained in Reference 13.

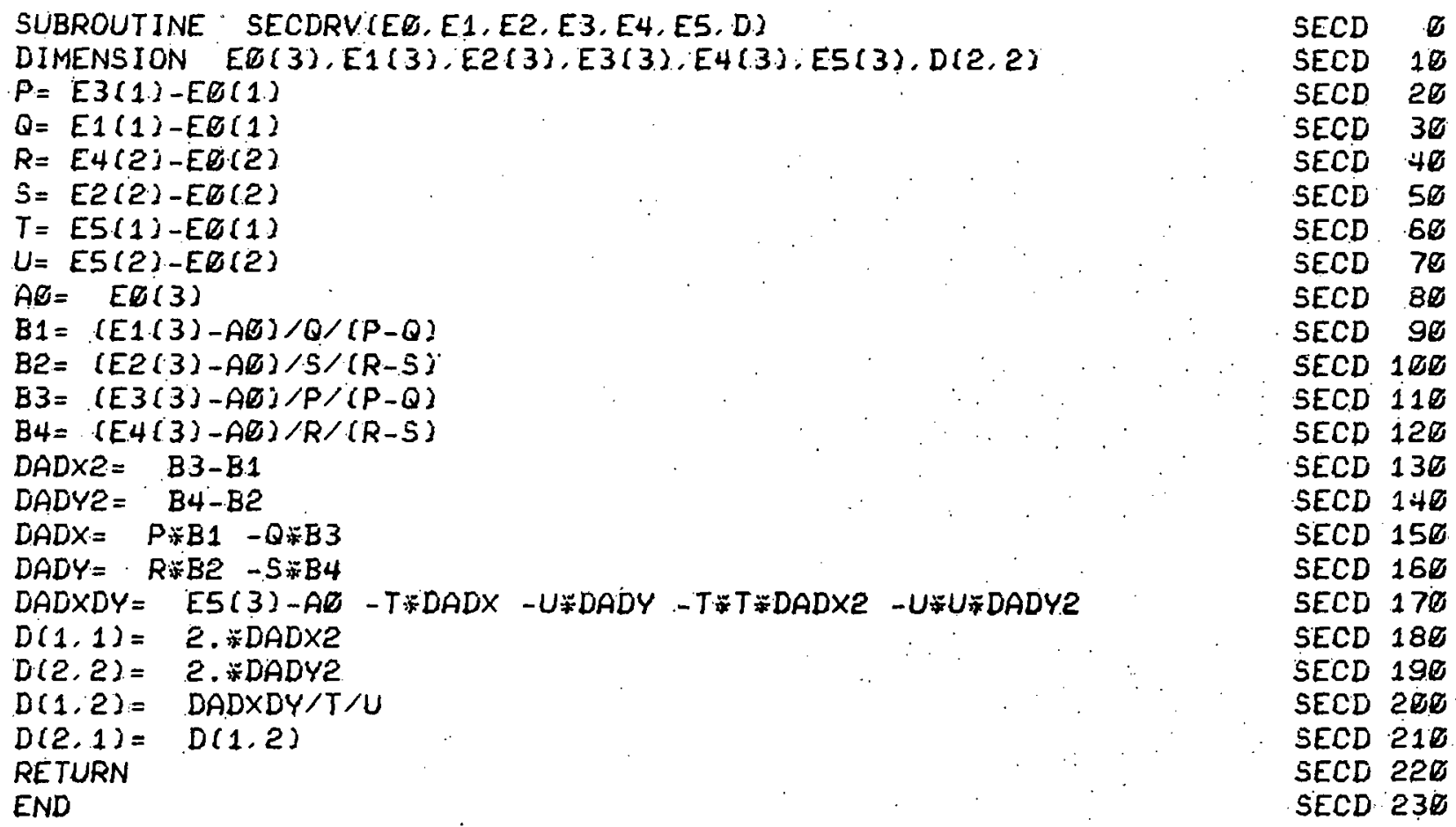


g. Job Control Language: Execution

The ASSM plotting routines and the SYMAP (Version V) program have been compiled using S/360 FORTRAN IV(H) with OPT $=02$. It is currently running on an IBM S/360 50-75 using OS MVT Release 20 under ASP.

The following JCL represents the execution step of the ASSM plotting system. SYMAP and the ASSM plotting routines have been linkedited into the ASSM. PROGLIB Library.

The data se.t. represented by ddnames FT01F001,.., FT04F001 are standard SYMAP scratch files. The receptor concentration data generated by ASSM is specified througlı logical unit 10 (FT10FD0i) The scratch file on logical unit 8 (FT08F001) contains the function values for contouring. It is written by SYMAP, and read and repositioned by FLEXIN.

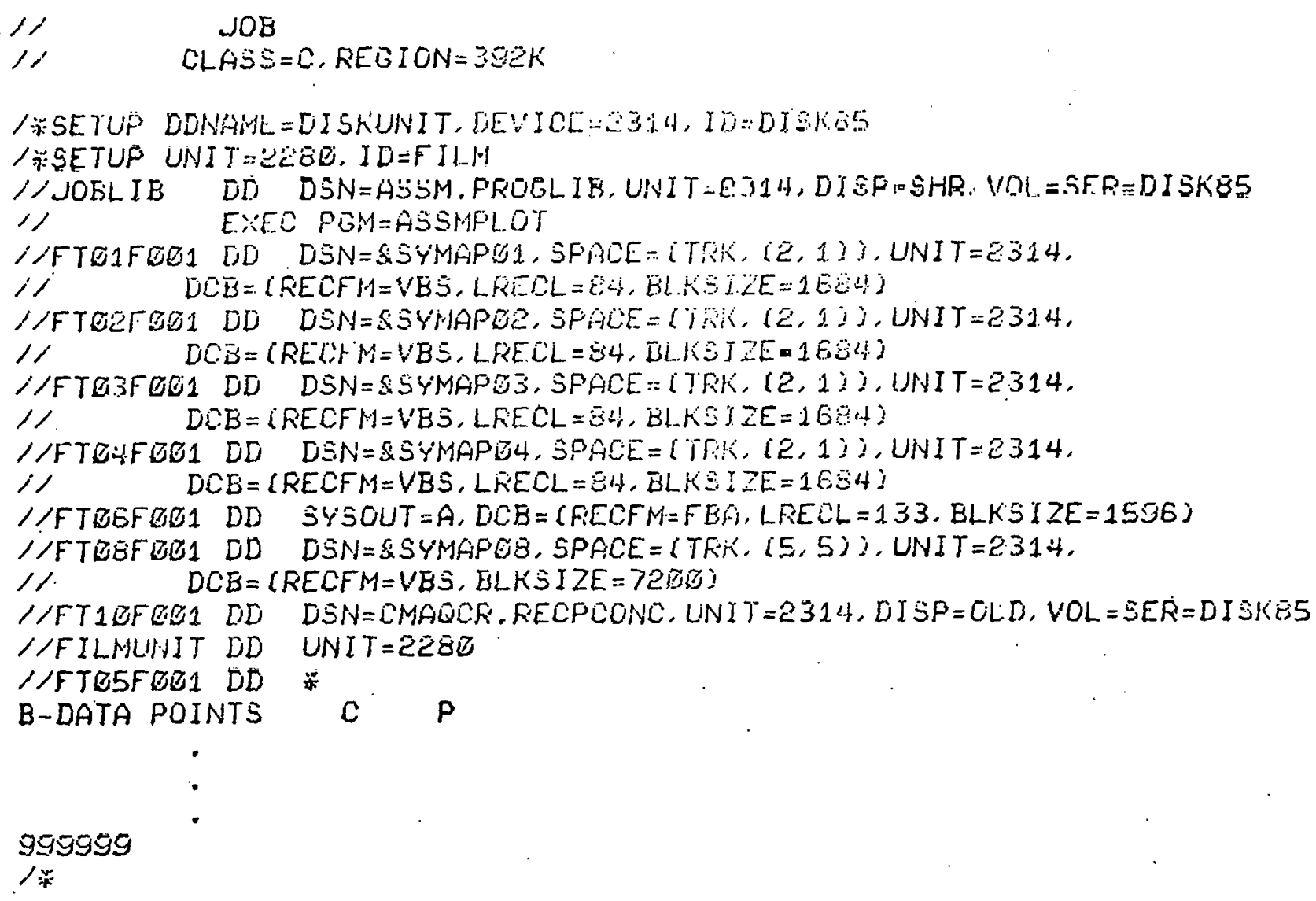




\section{Input Description}

The SYMAP contouring system serves as the basis for the ASSM plotting system. Familiarity with the use of the SYMAP program is assumed in this appendix. However, References 10 and 11 contain the necessary background information.

Input to the plotting system is composed of two separate data sets (files). One is the receptor concentration data output from ASSM. The other contains the plotting options. It is the latter input that is described here. Its deck structure, composed of four SYMAP packages, is displayed in Figure $\mathrm{C}-2$. Whenever possible, examples will reference the input and output for the sample problem: *. Thus, it would be advantageous to consult Figure $\mathrm{C}-3$, the completed input form for the sample problem.

Since our plotting system is based upon the SYMAP program, the input description will be considered in terms of the SYMAP packages. Distinctions will always be made to separate the options used for the SYMAP printer plots and the (2280) film plots.

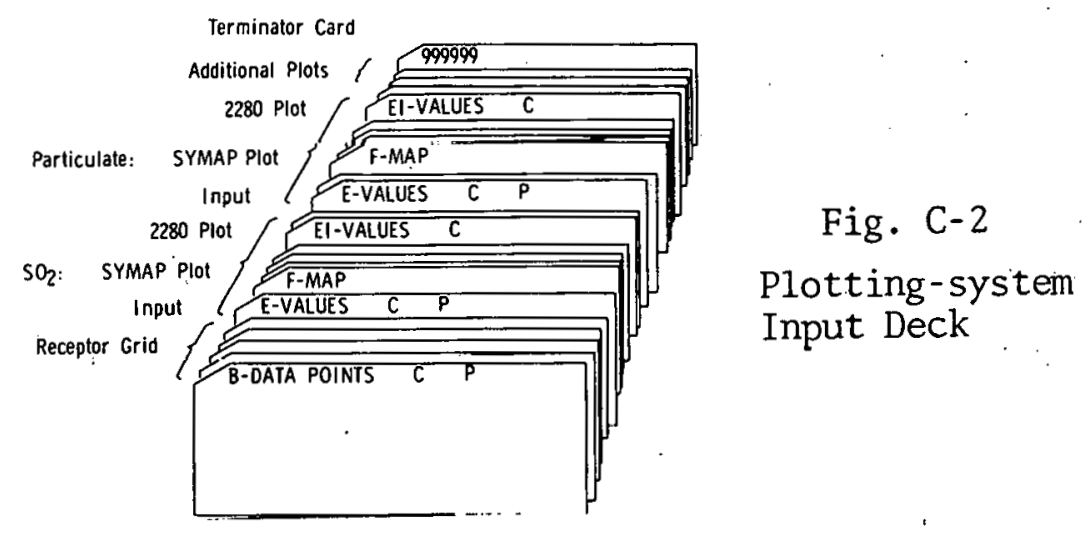

* Note: There is but one "sample problem" being considered. in Appendices B and C. 


\section{a. B-DATA POINTS}

This package inputs the coordinates of the receptor grid from the ASSM data file. It should be used but once for a given receptor grid. Additionally, this entry describes the ASSM data file and initializes the graphics parameters. The package is composed of the following five cards.

\section{$\underline{\operatorname{Card} 1}$}

This rard must contain B-DATA POINTS in columns 1-13, and any non-blank character in column 18. A non-blark character in column 23 will suppress the listing of the receptor grid coordinates.

\section{Card 2}

This card must contain a 1 in column 5 (IFORM) and a value not less than 340 . in columns 8-10. The current system can input a receptor grid with a maximum of 340 points: 


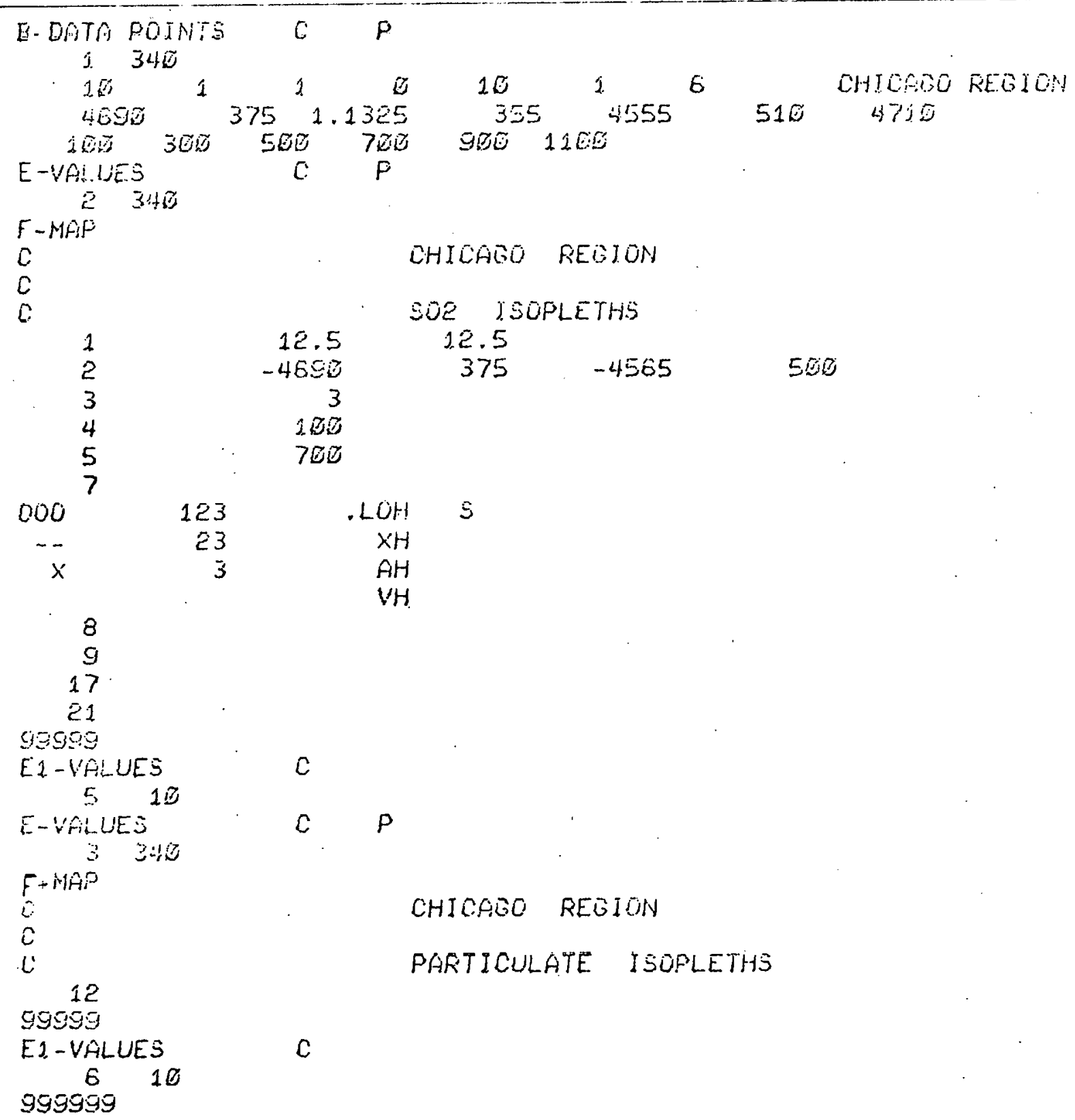

Fig. C-3. Input for Sample Problem 
$\underline{\text { Card } 3}$

$\underline{\text { Variable }}$

INPUT

NCASE

NSELC

I

ICASE
Columns

$$
1-6
$$

Logical unit number of the receptorconcentration-data file. It must not be $1,2,3,4$, or 8 . The next two variables position the input file. 7-12

Number of the initial case or unit

'INPUT' . This corresponds to the NCASE parameter of ASSM. $13-18$ Number of the first case to be considered on untt 'INPUT' . The receptor grid is taken from NCASE. If NCASE > ICASE, the first NCASE - ICASE cases are skipped on the file. Control parameter for selection of cases being considered. If $\leq 0$, cases are considered in order from NCASE. If $>0$, only particular cases are considered. Under this option, the case number is input through the appropriate E-VALUES package. Cases must still be selected in order. 
For example, if the first 10 cases were to be considered, then NSELC is $\leq 0$. If only cases 3,7 , and 10 were desired, then NSELC $>0$ and the three case numbers must be input through the E-VALUES packages.

$\begin{array}{ll}\text { NRECEP } & \text { The number of (selected) receptors to } \\ \text { be marked on the film plot. Their } & \text { numbers are input through the ASSM } \\ \text { file. } & \text { The number of copies of each film } \\ \text { plot to be made. The minimum value } \\ \text { NCOPYS } \quad 31-36 \quad \text { for NCOPYS is } 1 . \\ \text { N2 } \\ \text { The number of contour values to be } \\ \text { input. (See Card } 5 . \text { ) NZ } \leq 12 . \\ \text { Identifying information of at most } \\ \text { 16 characters that appears on film } \\ \text { output. Designed to repeat the METSET } \\ \text { parameter from ASSM for cross-referencing } \\ \text { purposes. }\end{array}$




\begin{tabular}{|c|c|c|}
\hline Variable & Columns & \\
\hline YMAX & $1-8$ & $\begin{array}{l}\text { Coordinate value of the upper row }(\mathrm{Y}) \\
\text { of the SYMAP printer plot. It is } \\
\text { equivalent to the "minimum vertical } \\
\text { coordinate" of FMAP elective number } 2 \text {. }\end{array}$ \\
\hline YMIN & $9-16$ & $\begin{array}{l}\text { Coordinate value of the leftmost } \\
\text { column }(X) \text { of the SYMAP printer plot. } \\
\text { It is equivalent to the "minimum } \\
\text { horizontal coordinate" of FMAP elective } \\
\text { number } 2 \text {. }\end{array}$ \\
\hline SIZE & $17-24$ & $\begin{array}{l}\text { Physical size, in inches, of the plotting } \\
\text { area on film. It must be } \leq 1.15 \text { inches. }\end{array}$ \\
\hline
\end{tabular}

The next four parameters specify the lower left and upper right corners of the film plotting area in the same units that specify the receptor grid. 


\begin{tabular}{|c|c|c|}
\hline XIPLT & $25-32$ & $\begin{array}{l}X \text { - coordinate of the lower left } \\
\text { corner }\end{array}$ \\
\hline X1PLT & $33-40$ & $\begin{array}{l}\text { Y - coordinate of the lower left } \\
\text { corner }\end{array}$ \\
\hline X2PLT & $41-48$ & $\begin{array}{l}\mathrm{X} \text { - coordinate of the upper right } \\
\text { corner }\end{array}$ \\
\hline X2PLT & $49-56$ & $\begin{array}{l}Y \text { - coordinate of the upper right } \\
\text { corner }\end{array}$ \\
\hline
\end{tabular}

These four values determine a square of side 'SIZE' over, which the isopleths will be drawn. In the sample problem, the receptor grid (Figure B-4) and the SYMAP grid are identical. However, the film plotting area is larger to accommodate the entire region. $\underline{\text { Card } 5}$

This card contains the NZ values to be contoured. They appear in fields of length six. 


\section{b. E-VALUES}

This package inputs the concentration levels of $\mathrm{SO}_{2}$ and particulate to be contoured. It contains two cards if NSELC $\leq 0$; otherwise a third card must be included.

Card 1

This card must contain E-VALUES in columns 1-8 and any nonblank character in column 18. A non-blank character in column 23 will suppress the listing of the concentration data at each receptor.

Card 2

This card contains, in column 5, either a

2 if $\mathrm{SO}_{2}$ levels are plotted, or à

3 if particulate levels are plotted after $\mathrm{SO}_{2}$ levels are plotted, or a

4 if particulate levels are plotted and $\mathrm{SO}_{2}$ are not plotted

for a given input case. Columns 8-10 must contain a value not less than 340 .

If NSELC $>0$, then include the following card. 
Card 3

Columns 1- 6 contain the case number (right-justified) of the particular case to be considered.

\section{c. F-MAP}

This package inputs the specifications for the printer isopleth plot to be made. All input to this package follows the standard SYMAP format. This is the only package in which no input through the supplied FLEXIN routine is made.

The options selected in this package will depend on the degree of complexity desired by the user. However, the following eleven options have proved to be most sufficient. A description of each is contained in References 10 and 11 .

For the first map in a given run,

\section{Elective number}

1
Description

$$
\text { size }
$$

extreme points

number of contour levels 


\begin{tabular}{cl} 
Elective number & \multicolumn{1}{c}{$\begin{array}{c}\text { Description } \\
4\end{array}$} \\
5 & maximum contour value \\
7 & symbolism \\
8 & suppress contour lines \\
9 & suppress histogram bars \\
$17^{*}$ & suppress tabulated data \\
$21^{*}$ & create "Type 8 "!
\end{tabular}

For subsequent maps, the use of elective number 12 to repeat previous map options is recommended. In the sample problem, this elective was used for the second map to repeat those options specified in the first F-MAP package.

\section{d. E1-VNLUES}

This paskage is used to provide additinnal entries into FLEXIN for purposes of contouring on film the values generated and stored on "Type 8 " by the preceding F-MAP package. It is necessary that an E1VALUES package immediately follow the F-MAP package to which it corresponds. The SYMAP function of this package is no longer applicable in this system. The package is composed of two cards.

*Described in Reference 10 only. 
$\underline{\text { Card } 1}$

This card must contain El-VALUES in columns 1-9 and any nonblank character in collumns 1.8 and 23 .

$\underline{\text { Card } 2}$

This card contains, in column 5 , either a 5 if $\mathrm{SO}_{2}$ values are being contoured or a 6 if particulate values are being contoured. Colum 10 of this card must contain a positive value. 
3. Output Description and Sample Problem

In Appendix B a sample problem, based upon the Chicago region for 16 different meteorological cases, was discussed. Included in Section 4 of that appendix was the output for the first of those 16 cases. In this section we present the plotting output corresponding to that sample case. A by-product of this discussion will be a description of the output obtained through the film-plotting portion of this system. A description of the SYMAP - generated output is contained in Reference 11.

The output from the ASSM plotting system is composed of three parts. The first is the SMMAP printer plot displayed in Figure C-4. The second is the (2280) film plot. A print of that $35 \mathrm{~mm}$ film is displayed in Figure C-5. The third part is the 'Map Sumnary Information". It is composed of the film-labeling information for crossreference purposes, a complete description of the meteorological data for this case, and a list of the selected receptors containing the location and pollutant concentration for each. Figure C-6 contains the Map Sumnary Information for the sample problem. 


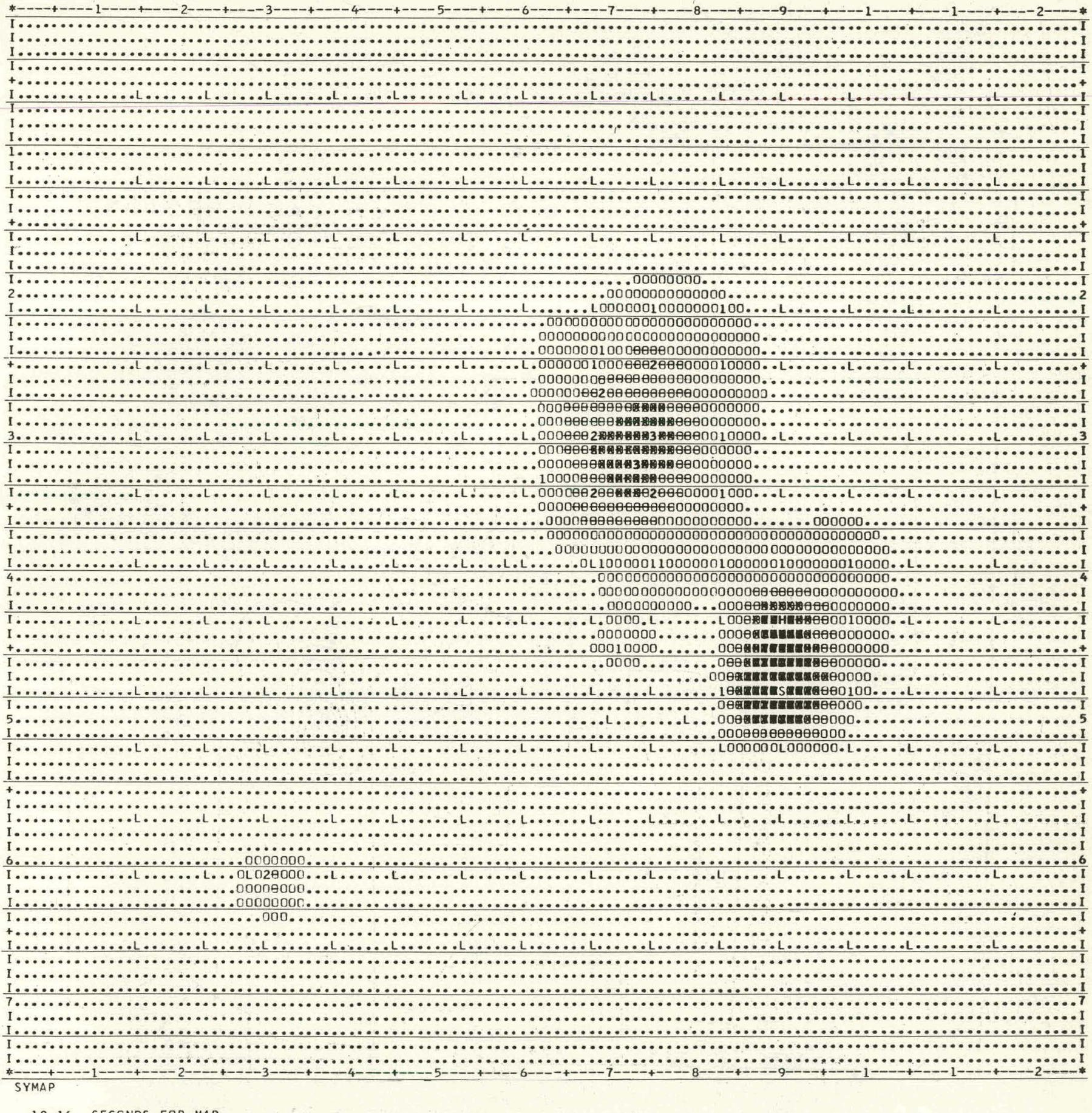

10.16 SFRONOS FOR MAP

TIME IS 0.19 MINUTES

c

CHICAGO REGION

c

SO2 ISOPLFTHS

Fig. C-4. SYMAP Output for Sample Problem 


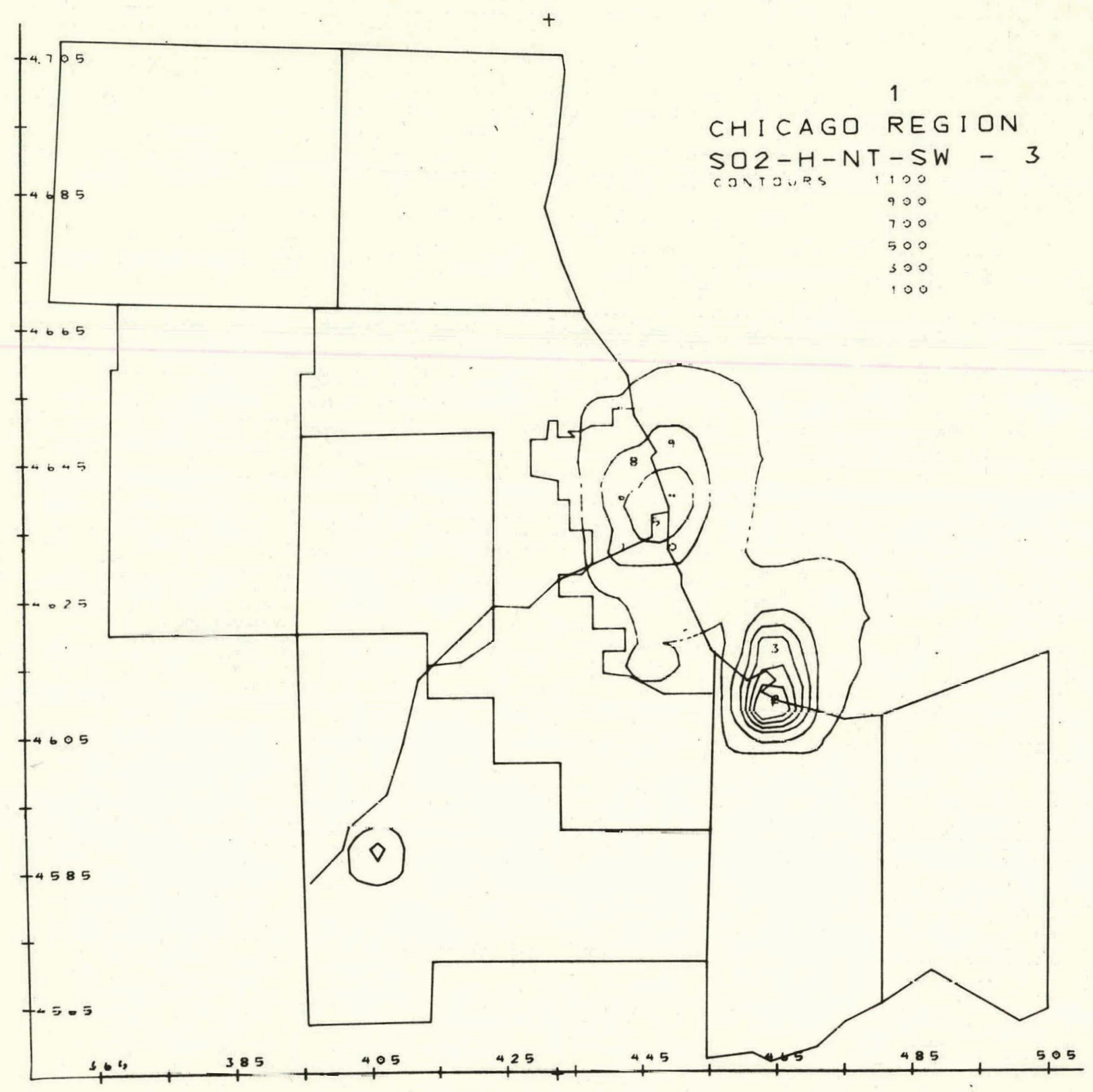

Fig. C-5. Film Output for Sample Problem 


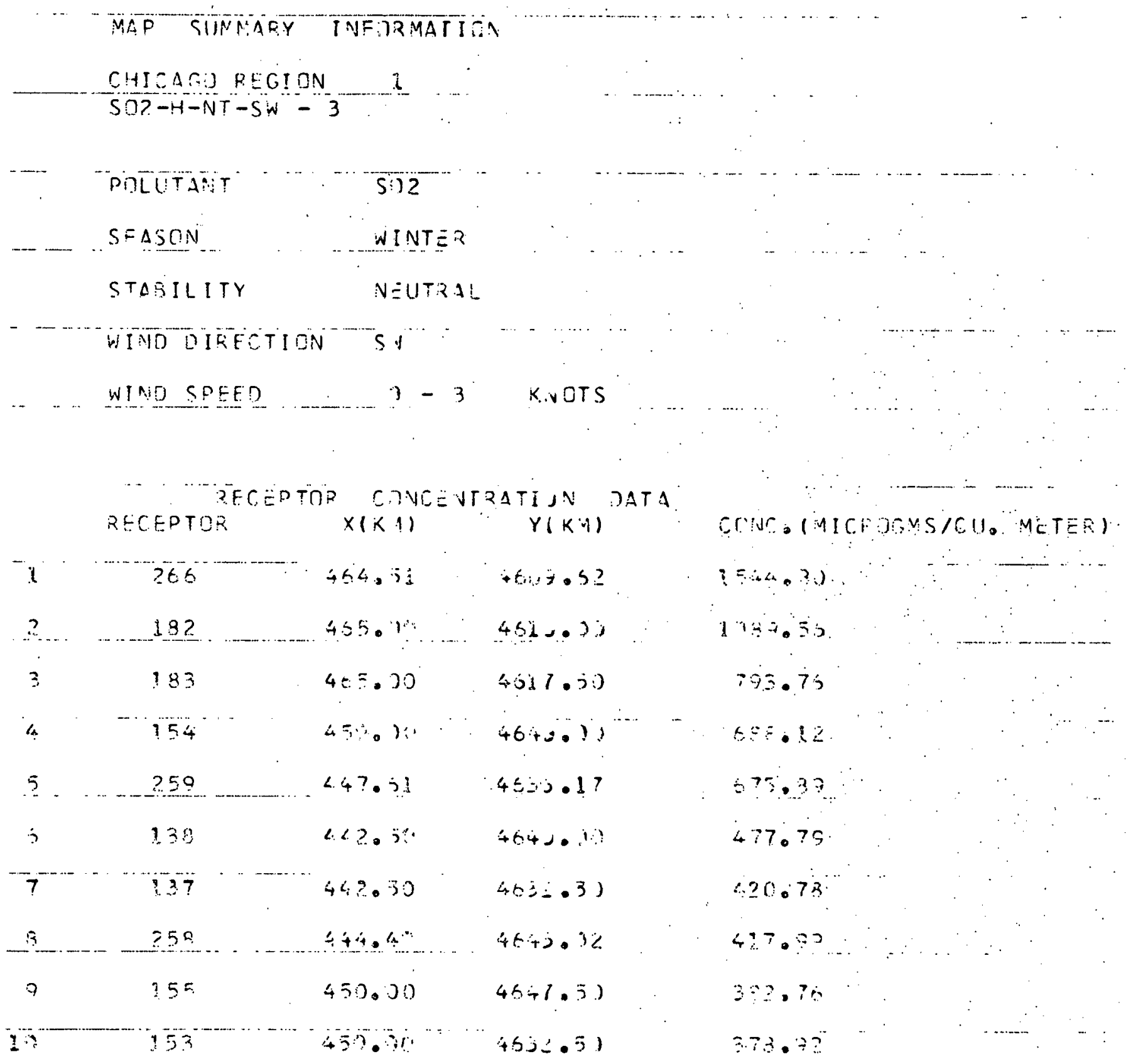

Fig. C-6. 'Map Summary Information" for Sample Problem 
An explanation of the labels that appear on the film and in the Map Sumnary Information is contained in Table C-1.

The upper right-hand portion of the film output contains three lines of identifying information, followed by the contour levels plotted. A description of the three lines follows.

The first line contains the case number. The LABEL parameter $^{*}$ forms the next line. The third line is a description of the pollutant and meteorological data. It is composed of at most 15 charaçters.

Position

1-3 5

7-8

$10-12$

$14-15$
Description

pollutant season stability class

wind direction

wind speed

* See page 189. 
TABLE C-1. Film and Printer Labels

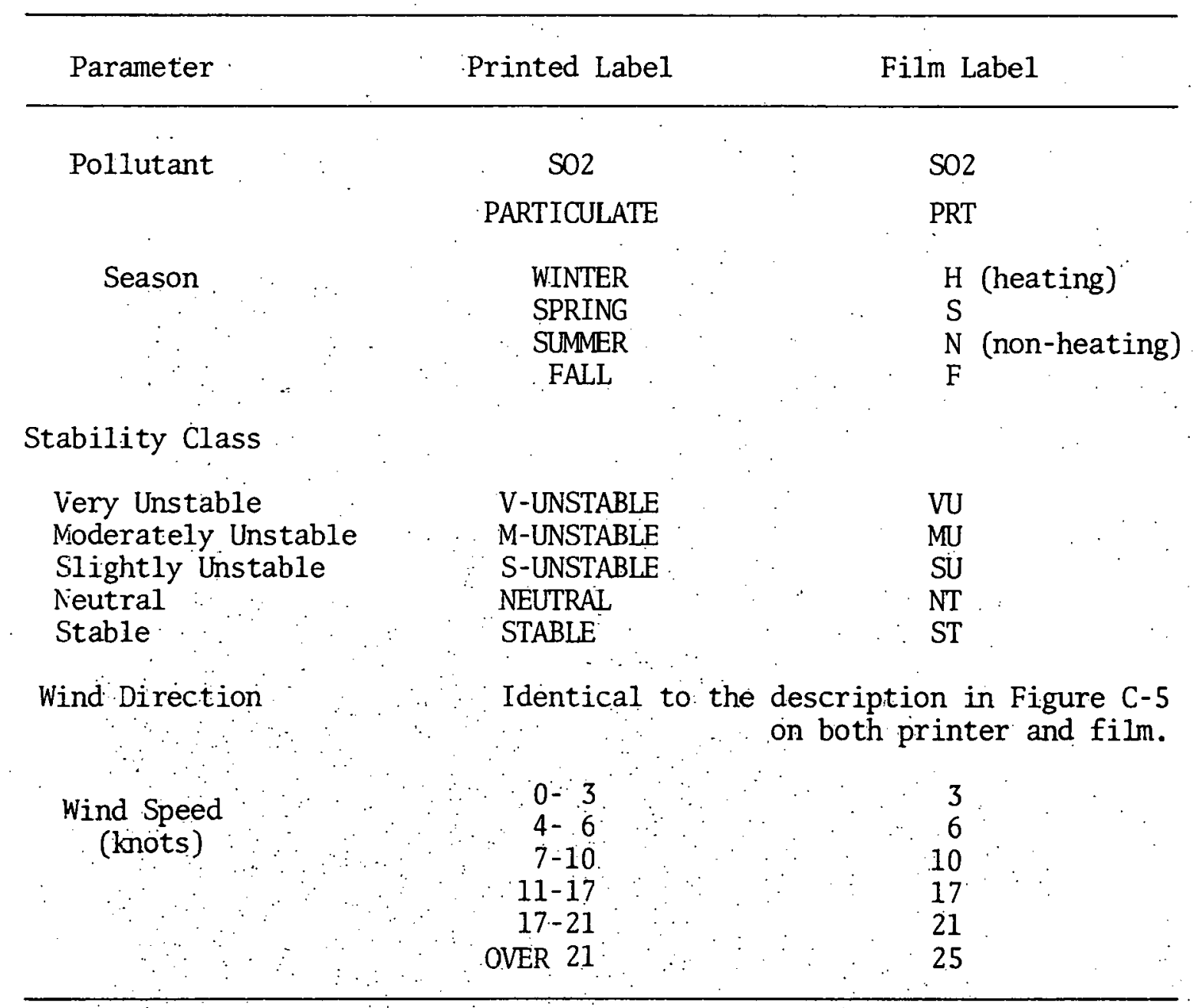


APPENDIX D

Episode Display

A manual display method can be used to provide a medium for graphically planning control strategies. Pollution contours plotted on $35 \mathrm{~mm}$ film can be mounted on a traditional slide mount or aperture card. The aperture card provides a simple means for sorting the different contours. Figure D-1 shows the outline of a typical aperture with a film contour mounted. The aperture card is nothing more than an IBM card with a hole cut in it for mounting film. Data which identifies the contour is punched on the left half of the card (50 columns), and the cards can be sorted using a manual sorter or an IBM 082 Card Sorter.

The pollution contours, mounted on either traditional or aperture card mounts, can be projected onto a screen for viewing with a large format. A special projector made for aperture cards and traditional $35 \mathrm{~mm}$ slide mounts is available from the $3 \mathrm{M}$ company. An artist's sketch of "a display unit which can be used to plan episode control strategies is shown in Figure $\mathrm{D}-2$. The film is inserted in the opening below the viewing area and an internal reflecting mirror projects the image onto a rear-frosted clear plexiglas viewing screen. The viewing. area is approximately $40^{\prime \prime} \times 40^{\prime \prime}$ and has a smooth front surface. Episode strategy planning can include plotting individual source contributions onto plexiglas, which can later be washed clean with water or alcohol. 


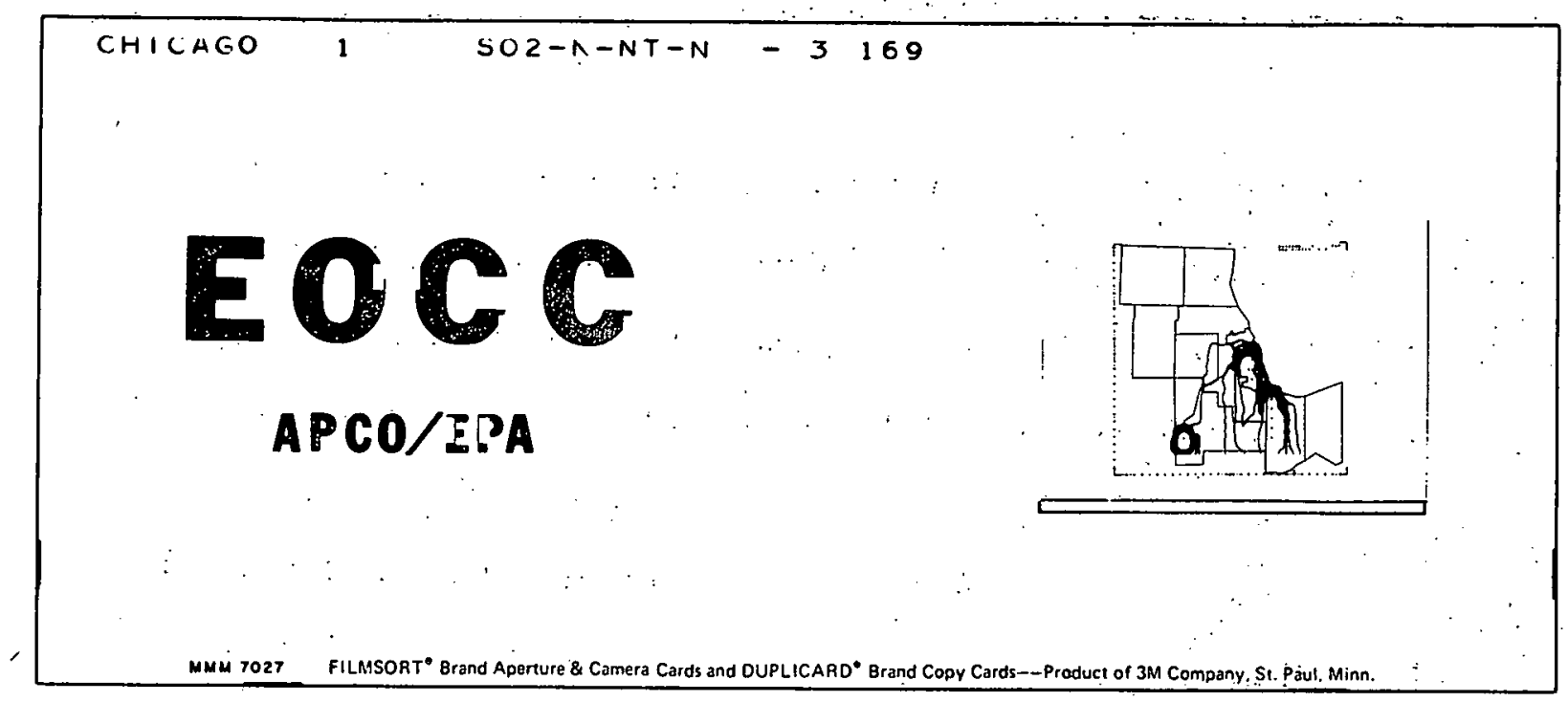

Fig. D-1. Typical Aperture Card with Regional Isopleths

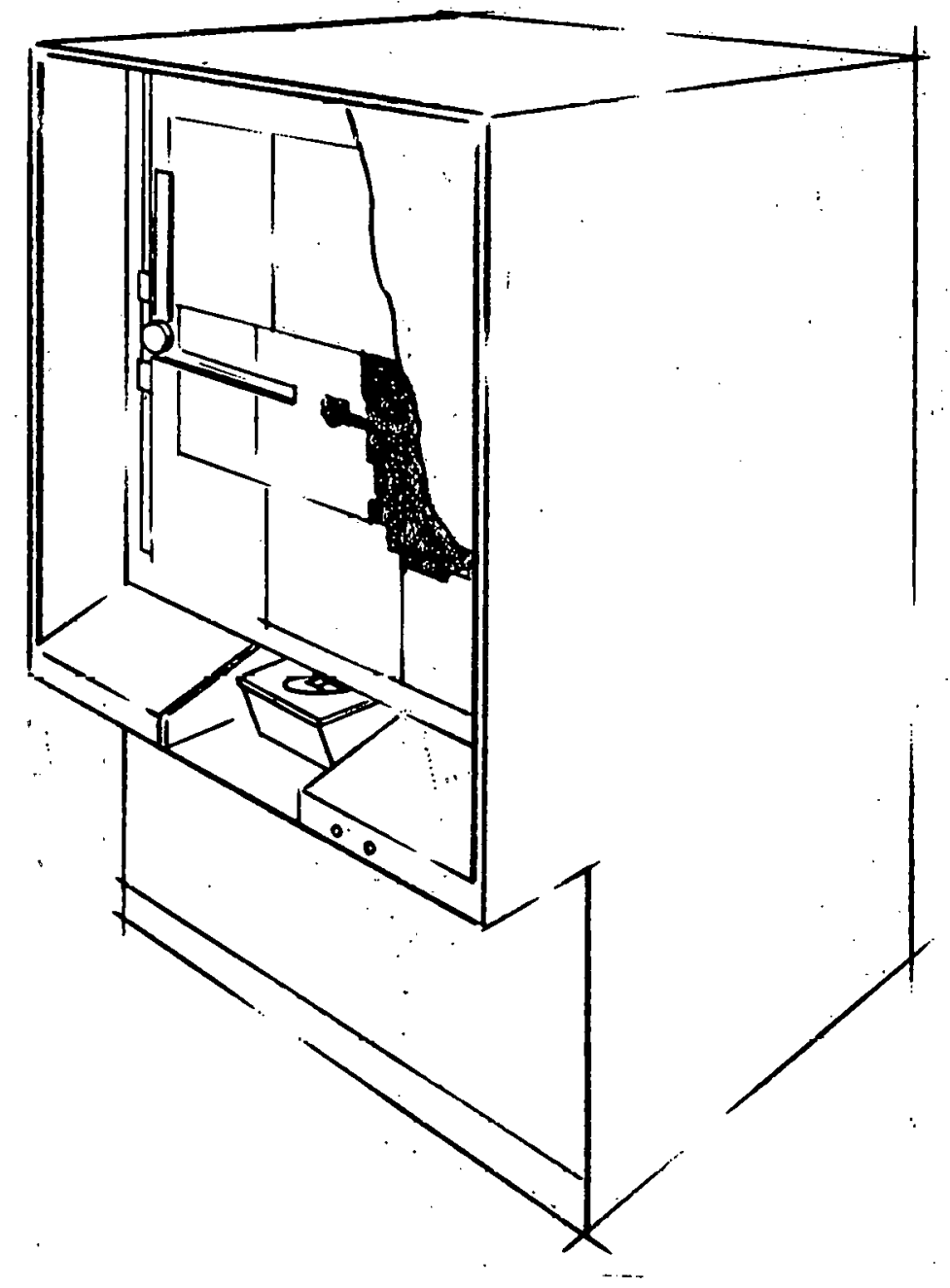

Fig. D-2. Episode Display Unit. ANL Neg. No. 190-35. 


\section{ACKNOWLEDGMENTS}

The contributions of Argonne's Ralph Carter (for developing the episode-display capability) and Mary Snider (for work on source inventory processing programs) are gratefully acknowledged. Staff of the Environmenta1 Protection Agency's Emergency Operations Control Center _ Joan Hrenko; Robert Kornasiewicz, Charles Whitmore; and especially Darryl D. Tyler, Chief of the Center — are to be thanked for continuing assessment and final review of the project. Finally, A.D. Rossin (Argonne Center for Environmental Studies) directed and inspired the entire Episode Control Program, of which this project was an integral part. 


\section{REFERENCES}

1. Air Quality Display Model (AQDM), prepared for Dept. of Health, Education, and Welfare, Public Health Service, by TRW Systems Group (Nov 1969).

2. Air Quality Implementation Planning Progrom, prepared for Environmental Protection Agency, National Air Pollution Control Administration (Nov 1970).

3. Rapid Survey Technique for Estimating Community Air Polzution Emissions, Dept. of Health, Education, and Welfare, Public Health Service, No. 999-AP-29 (Oct 1966).

4. L. A. Conley et al., Isopleth-Area Tables, ANL/ES-8 (Oct 1971).

5. D. M. Rote, J. W. Gudenas, and L. A. Conley, Studies of the Argonne Integratod-puff Model, ANL/ES-9 (Oct 1971).

6. D. Bruce Turner, Workbook of Atmospheric Dispersion Estimates, Public Health Service Publication, No. 999-AP-26 (1970).

7. G. A. Briggs, "Some Recent Analyses of Plume Rise Observation," Second International Clean Air Congress of the International Union of Air Pollution Prevention Association, December 6-11, 1970.

8. G. A. Briggs, Plume Rise, U.S. Atomic Energy Commission, Division of Technical Information (1969).

9. User's Reference Manual for Synagraphic Computer Mapping 'SYMAP,' Version V, Laboratory for Computer Graphics and Spatial Analysis, Harvard University.

10. M. T. Matthies, Introductory User's Manual for SYMAP Contour Maps, AMD Technical Memorandum No. 225, Argonne National Laboratory (Mar 1971).*

11. IBM System/360 System Component Description: IBM 2280 Film Recorder, Form A22-6853.

12. W. R. Wesse1, Some Subroutines for Producing Captioned Contour Line Plots and Line Graphs on Film, AMD Technical Memorandum No. 191, Argonne National Laboratory (Feb 1970).*

13. D. Carson, "A Film-Plotting Subroutine Package (FSP) for the IBM 2280 Film Recorder," AMD Technical Memorandum No. 167, Argonne National Laboratory (June 1968).

14. Harry Moses and Mary A. Bogner, Fifteen-year Climatological Summary: January 1, 1950-December 31, 1964, Argonne National Laboratory, DuPage County, Argonne, IZZinois, ANL-7084 (Sept 1967).

\footnotetext{
*Available upon request from Applied Mathematics Division, Argonne National Laburatory.
} 